\title{
Social and Literary Constraints On Women Writers \\ In New Zealand 1945-1970
}

\author{
By \\ Michael John O'Leary
}

\begin{abstract}
A thesis
submitted to the Victoria University of Wellington in fulfilment of the requirements for the degree of Doctor of Philosophy

In Gender and Women's Studies
\end{abstract}

Victoria University of Wellington

2011 


\section{Contents}

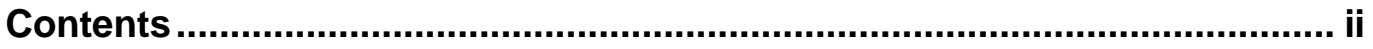

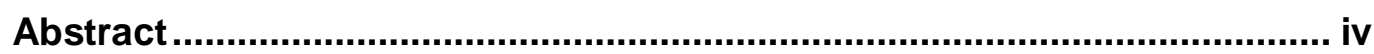

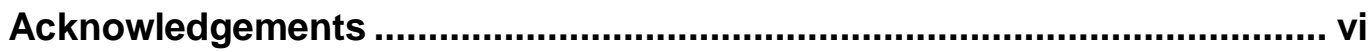

Chapter 1 Introduction......................................................................... 1

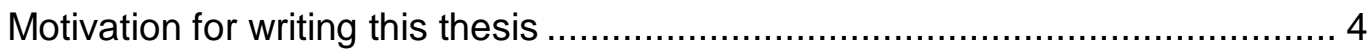

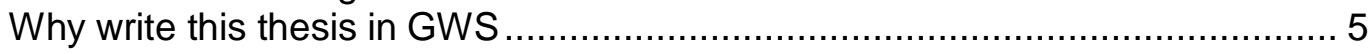

Chapter 2 Methodology/Literature Review.............................................. 9

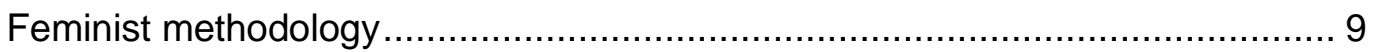

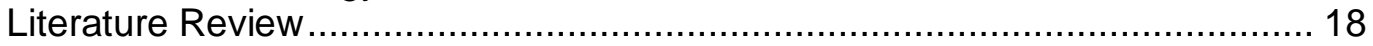

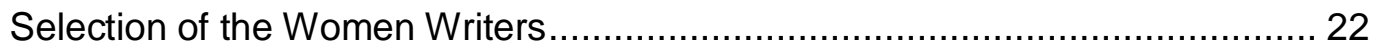

Chapter 3 Social and Historical Background Post WW1 ........................... 25

Industrialisation in New Zealand 1945-1970 ................................................ 30

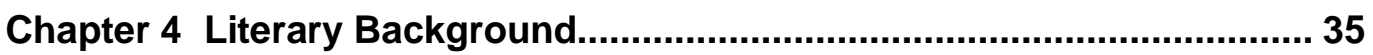

Georgians versus Modernists .............................................................. 35

No place for a woman ............................................................................ 41

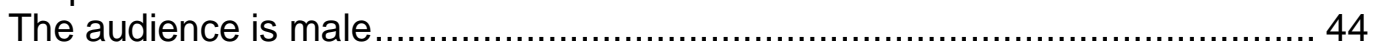

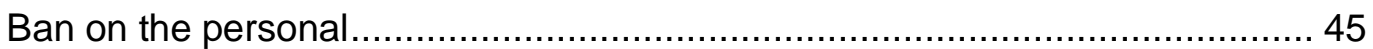

Giving New Zealand women 'a swelled head' .............................................. 47

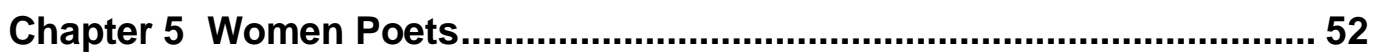

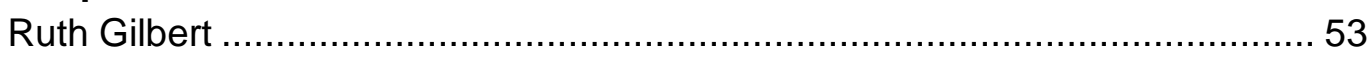

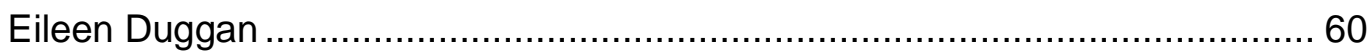

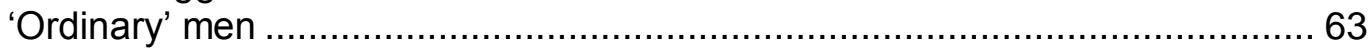

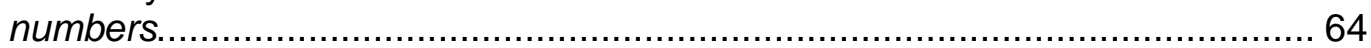

Chapter 6 Women Novelists.................................................................... 77

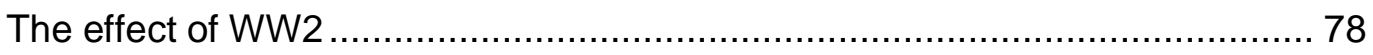

Mary Scott, Joyce West \& Nelle Scanlan .................................................. 83

Rosemary Frances Rees: 1876-1963 .................................................... 86

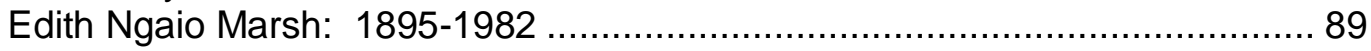

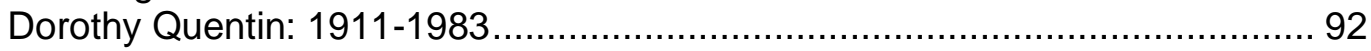

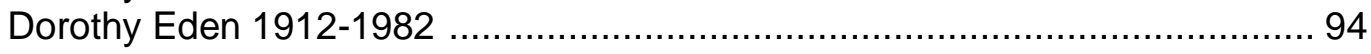

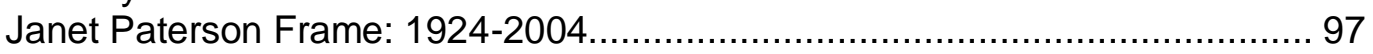

Chapter 7 Three Marriages and a Single Parent ................................... 104

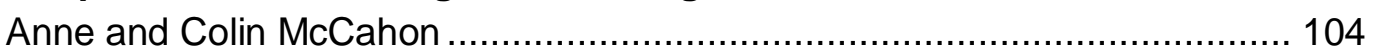

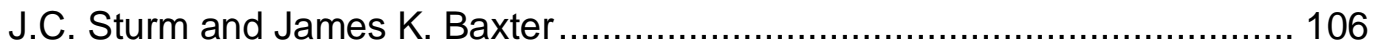

Meg and Alistair Campbell ................................................................. 110

Karen Peterson Butterworth ................................................................. 113

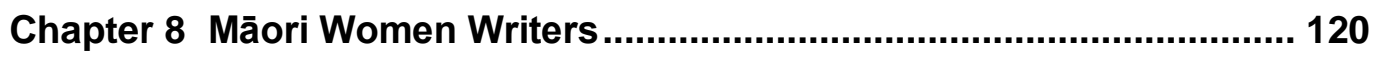

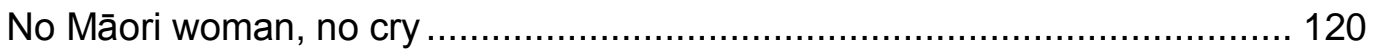

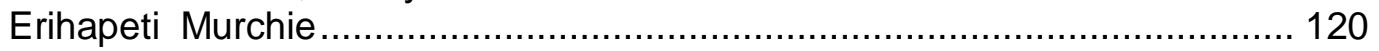

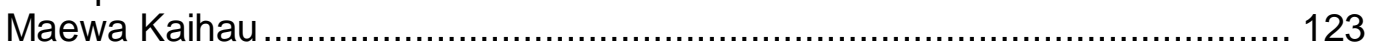

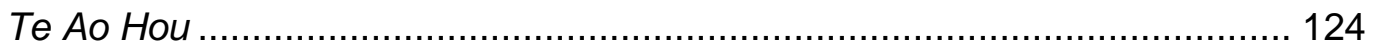




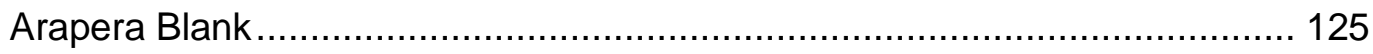

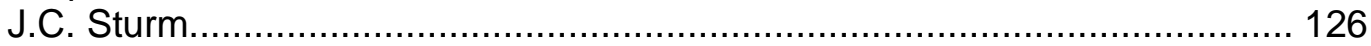

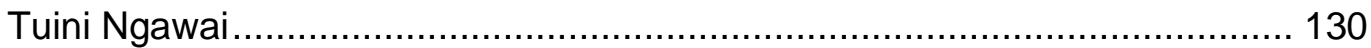

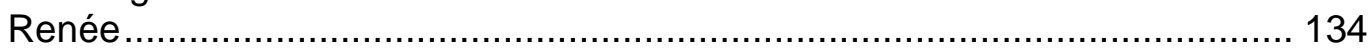

Chapter 9 Lesbian Writing in New Zealand.......................................... 138

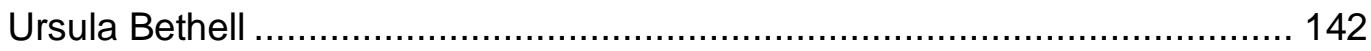

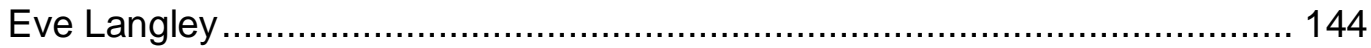

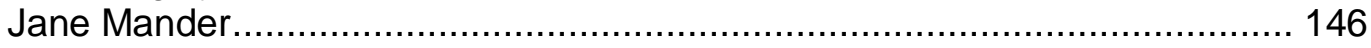

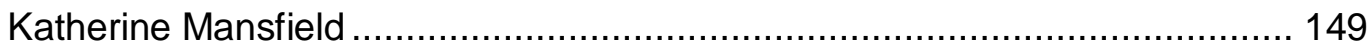

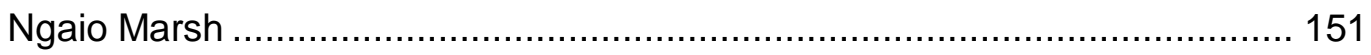

Esma North and Marjory Lydia Nicholls ................................................. 153

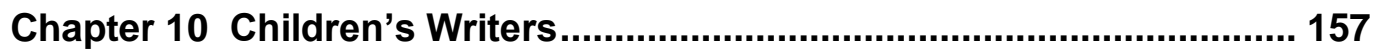

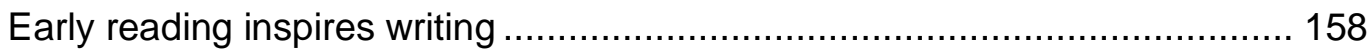

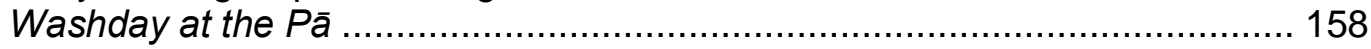

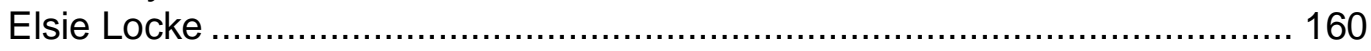

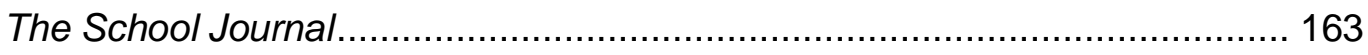

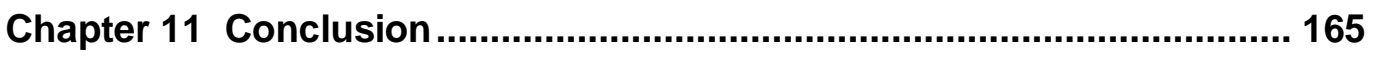

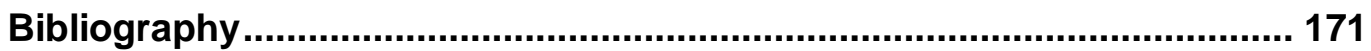

\section{List of Appendices}

Appendix 1 From ROSEMARY REES: A BIBLIOGRAPHY ....................... 204

Appendix 2 From NGAIO MARSH: SELECT BIBLIOGRAPHY .................. 209

Appendix 3 From DOROTHY QUENTIN: A SHORTER BIBLIOGRAPHY .. 214

Appendix 4 From DOROTHY EDEN: A SHORTER BIBLIOGRAPHY ....... 219

BOOKS IN CHRONOLOGICAL ORDER.................................................. 219

Appendix 5 ELSIE LOCKE: SELECT BIBLIOGRAPHY ............................. 224

Appendix 6 RUTH GILBERT: BIBLIOGRAPHY .................................... 230

Appendix 7 JANET FRAME: BIBLIOGRAPHY ........................................ 233

Appendix 8 E-mail correspondence between Niel Wright and Cameron La

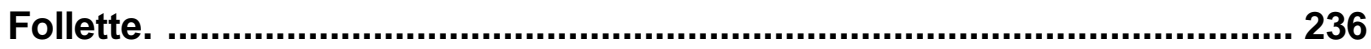

Appendix 9 New Zealand Poetry Checklist ............................................ 240

Appendix 10 New Zealand Fiction Checklist ......................................... 249

Appendix 11 Louis Johnson's review of Ruth Gilbert's book The Sunlit Hour

260

Appendix 12 Willow Macky's letter to the editor of numbers 7 regarding Johnson's review of Ruth Gilbert's book The Sunlit Hour in numbers 6 and Johnson's reply. 262

Appendix 13 Publisher: Spiral Collective. 265 


\section{Abstract}

This study explores the reasons why so few women writers in Aotearoa New Zealand were seen as prominent figures in the literary scene from the end of World War Two up to the time when the feminist movement gained momentum, in the late 1960s and early 1970s. Using feminist methodology, I examine whether women writers were deliberately underrepresented and their work trivialised by the male writers, critics and publishers of the time. What were the factors accounting for this underrepresentation?

I also discuss to what extent there were successes and achievements, either literary or commercial, for the women writers of the time despite their real and/or perceived exclusion from the canon. Literary writers by definition create public documents, including manuscripts, working papers, and letters. The existence of such records means that perhaps more so than for many groups, we have evidence regarding attitudes, intentions, motives and responses to situations of the individual women writers of this period with which to answer these questions. The Georgians vs Modernists debate is examined.

The starting date of 1945 for this thesis is significant for it was in that year that Allen Curnow's anthology A Book of New Zealand Verse was published. One of the striking things about the collection is that only two of the sixteen poets represented are women: Ursula Bethell and Robin Hyde. He did invite and encourage Eileen Duggan to contribute but she declined. Curnow's book went into a second edition in 1951 with twenty three poets, three of whom were women, Ruth Dallas being the third. In 1953 a book titled POEMS: Anthology of New Zealand Women Writers was published. This could be seen as an attempt to make up for Curnow's omissions.

As evidence, I look to women writers of the time to see what restrictions on writing and publishing existed. In 1957 the literary magazine numbers published a letter by Willow Macky in which she criticises the critics of the New Zealand literary scene for their unfavourable reviews of the latest book by the poet Ruth Gilbert, The Sunlit Hour. Macky's letter was both a plea to 
her male colleagues and an indictment against them for their treatment of their female counterparts. She states: 'Most women, if they wish for success, will try to conform, monkey-like, to the masculine pattern; others, by remaining true to their feminine insight, risk opposition and failure in maledominated fields' (Macky, 1957: 26). Was this the case and if so why?

The 1970 cut-off date for this thesis coincides approximately with the development of the feminist movement in New Zealand. However, according to lesbian-feminist poet Heather McPherson, prejudice continued. McPherson had poems published in Landfall and had approached Leo Bensemann, then Caxton Press and Landfall editor, with a collection of poems. She mentioned to him that she had become a feminist. His reply was that Rita Cook (Rita Angus) had become a feminist 'but it didn't do her any good either' (McPherson, 2007: 116). These two examples illustrate some of the difficulties and antipathies that existed between the male and female literary figures, like Curnow and Macky, of the period which inform this thesis.

To answer the questions posed above, I explore the social and historical context for women in this period, including the impact of the Second World War, and cover the careers of women poets and novelists, including some detailed case studies. I also examine the particular issues facing Māori and lesbian writers. I conclude that a supportive and encouraging environment was rarely available for women writers from 1945 to 1970, that most struggled to be published and appreciated, and that only later, if at all, were many of these important writers properly recognised. 


\section{Acknowledgements}

Firstly, I want to acknowledge and thank my supervisors, Alison Laurie and Prue Hyman from the Gender and Women's Studies Department of Victoria University, Wellington, along with Lesley Hall, all of whom supported the idea for this thesis from the time I first proposed it. Further, Alison and Prue have been very enthusiastic and supportive throughout the process of researching and writing my work, offering much material and moral assistance. I would also like to thank Deborah Laurs from the Post Graduate section of Student Learning Support Services at Victoria University for her assistance with technical matters.

I thank the staff of the Alexander Turnbull Library, Jillian Spiers and the reference staff of the Victoria University of Wellington Library, for their assistance and advice, and Archives New Zealand. I also acknowledge the assistance and support of private scholars Dr. F.W.N. Wright, Rowan Gibbs, and Mark Pirie who provided me with much unpublished and privately published work, as well as their comments on many aspects of this work. I would like to thank Wellington bookseller John Quilter, who alerted me to much arcane and out of print material on the subject of my thesis, as did Peter Trewern from New Zealand Book Auctions. I also thank the Poetry Archive of New Zealand Aotearoa.

I would like to thank my sister Clare O'Leary and her partner Cathy Ellis, both of whom have helped with research and reading through the thesis at various stages. I would like to thank my friends and whānau who have sustained me throughout. In particular my friend Moana Cleverley, my sister Patricia, my brother Gerrard, my son Te Amoraki, his mother Aroha and his sister Manakore, all of whom have encouraged me. I acknowledge my Uncle and Auntie, Dinny and Beryl O'Leary and their family, who took us in when our parents died, and who encouraged me in my formal education. I would like to thank my friend Winsome Aroha, who has been the inspiration behind much of my work over many years, and her sister Fiona Murchie, who, as the kaitiaki of Erihapeti Murchie's taonga on behalf of the Murchie whānau gave me access to personal papers. Also their father, Malcolm Murchie, for his 
aroha and assistance with the work of his wife, Erihapeti. Bill Dacker, Bryan Harold and lain Sharp are also due thanks. I would also like to thank my Paekakariki whānau who have helped and sustained me in many ways, including Ani and Helena Toki, Ruth Placzek, Sue Apperley, Don Polly, the Baxter whānau, Irving and Moira, the Campbell whānau, Adele, John the Postie and Horace the Grocer.

Lastly, I want to thank all the women, friends and lovers, who over my 60 years on earth have cared for me and been part of my life. I would also like to thank all the wonderful women poets and writers who have shared my life over the last three and a half years. It has been a privilege for me to be one of the people to tell their stories, as they have told their stories over the years. I hope this small mahi can make their own work become more accessible and acceptable to the wider literary community of New Zealand, for this has been my main aim in undertaking this study.

Ngā mihi kia koutou katoa

Arohanui Michael O'Leary

This thesis is dedicated to the memory of our parents Maurice and Patricia O'Leary who both died in 1968. The last song mum sang to me went: 'Hey Jude, don't make it bad; Take a sad song and make it better'. It is also dedicated to our sister, Cathleen, who died in 1954 aged 22 months. 


\section{Chapter 1}

\section{Introduction}

Kia ora tātau

He mihi kia koutou

Mā te ako ka mārama

Mā te mārama ka mātau

Mā te mātau ka ora

Horahia te marino

Horahia i Rotorua

Tukua te rangi mo te ruri

Kia rerehu $-\mathrm{i}$.

E hinawa - e!

Nō reira: tēnā koutou, tēnā koutou, tēnā koutou katoa.

By learning comes understanding

Through understanding comes knowledge and wisdom

Through knowledge and wisdom comes life and well-being

Spread out below lies Rotorua Lake;

How calm and still it lies!

This is our day for dance and song

How far will the sound travel!

My name is Michael O'Leary, I was born in Auckland in 1950 and I am from Irish and Te Arawa ancestors. The whakatauki or proverb I have introduced myself with is a mixture of two works: the first tells of the importance of knowledge and wisdom as life-affirming aspects of being a human in this world, the second comes from my own tribal roots and tells of the natural 
world, and how we must celebrate both the natural and human worlds in song and dance, and most writers, academic or otherwise, often ask the question: 'How far will my voice and words travel?'

I am a writer, poet, novelist, artist and publisher, my Earl of Seacliff Art Workshop imprint has published over 120 titles of New Zealand literary works and in 2009 we celebrated 25 years of publishing. My own writing includes 5 novels, several volumes of poetry, short stories, plus several non-fiction publications. My writing has been published in anthologies and my art work has shown in galleries. I include this whakaatu kupu (word introduction or greeting) as a way of acknowledging feminist research methodology which encourages the 'researcher as a person' (Reinharz, 1992: 240).

In her introduction to Feminist Research in Theory and Practice Gayle Letherby stresses the need 'to acknowledge the location of ourselves in research and writing', and earlier she states that 'our personal biographies are also relevant to the research that we do in terms of choice of topic and method' (Letherby, 2003: 9), hence this introductory note. Also, as a publisher it has been my philosophy to include and encourage as many women writers as possible, depending on the material available. In the history of my Earl of Seacliff publishing house published last year, The Earl is in ... 25 Years of the Earl of Seacliff, it is noted of the 61 authors 26 are women (Pirie, 2009). In the 1992 anthology I edited, Wrapper, of the 35 contributors 15 are women (O'Leary, 1992).

This thesis explores the reasons why so few women writers in New Zealand appear as prominent figures in the literary scene during the period from the end of World War Two up to the time when the second wave of the New Zealand feminist movement began, in the late 1960s and early 1970s. It discusses the evidence on whether women writers were deliberately underrepresented and their work trivialised by the male writers and publishers of the time. What were the factors accounting for this under-representation?

I provide an overview of the women writers and their acceptance or otherwise in New Zealand literature from 1945 to 1970, based on an investigation of the literary world of the time, plus one example from the art world which in many respects is similar in attitude and underlying conditions. 
This includes an examination of the evidence regarding the extent to which many New Zealand women writers felt excluded or belittled by their male counterparts and their analysis of the reasons for this - together with discussion of the accuracy of their perceptions. What are the factors accounting for their seeming lack of representation and how significant is each?

To what extent were there successes and achievements, literary, commercial, and academic, for the women writers of the time, despite any real or perceived exclusions? The significance and importance of my thesis lies in the evidence and the documentation of the questions and answers I provide. Such documentation will contribute to the knowledge of this important era in the development of our literature. The dates selected are significant for it was in 1945 that Allen Curnow's anthology of New Zealand verse appeared for the first time. One of the striking things about the collection, as previously stated, is that only two of the sixteen poets, Robin Hyde and Ursula Bethell, represented are women. Curnow's book went into a second edition in 1951 with twenty men and three women included, Ruth Dallas being the third. Were more women asked to contribute to the anthology but refused and, if so, why? This is discussed later in the thesis in relation to Eileen Duggan.

Because this thesis deals with litterateurs, literary writers, documentation is an important element in the presentation of the writers and their work. Literary writers by definition create public documents, over what may be a long lifetime, including manuscripts, working papers, and letters. The existence of such records means that, perhaps more so than for many groups, we have evidence regarding attitudes, intentions, motives and responses to situations of the individual women writers of this period. The appendices included in this thesis are designed to provide information not freely available thus far. As with this thesis as a whole, they are laid out for future scholars and researchers to use as a springboard for further work. It is hoped that this thesis will bring an awareness of the issues I address for future reference, and it in no way claims to be definitive or exhaustive. 
Subsidiary questions relate to specific issues and groups of women writers. 1945 saw the end of WW2 and the return of many thousands of servicemen from Europe. Did their return also mean a return to traditional family gender roles, not just in the home but also outside the domestic situation, including the literary world? Was there a residual resentment held by the men returning from the war towards the women who stayed at home, and did such attitudes also cross over into the post-war literary environment? Beyond individual women writers there is evidence to suggest that in the period 1945 to 1970 , different groups of women were treated differently, or simply ignored as being 'other', in particular, Māori women writers and lesbian writers.

\section{Motivation for writing this thesis}

One of the motivations for me to write a $\mathrm{PhD}$. thesis on this topic came from my MA thesis in English at VUW. The subject for that thesis was small press publishing in New Zealand from 1969 to 1999, subsequently published as a book by Wellington publishers Steele Roberts in 2007. My introductory chapter outlined some of the history of New Zealand literature as printed word up to 1969. What struck me was the under-representation of women writers in that period before the 1970s, according to most of the literary commentators.

However, I knew this to be untrue because of my many years as a second-hand bookseller. I realised this was an area that needed further investigation, and that the questions raised in my Masters thesis signalled a direction for important new research. The time period of this thesis ends in 1970. It is outside the scope of this study to cover the explosion of energy running through the 1970s in what is often referred to as Second Wave Feminism. Yoko Ono in her 1972 song 'Sisters o sisters' brought into popular culture some of the frustrations and sentiments that women were feeling at the time: 
We lost our green land, we lost our clean air,

We lost our true wisdom and we live in despair.

O sisters, o sisters, let's stand up right now,

it's never too late to start from the start

(Ono, 1972: song lyric).

During this period women in New Zealand began to 'start from the start' with the Women's Art Movement that set up art galleries, holding their own exhibitions so they were no longer reliant on gallery owners and art dealers who were predominantly men. At the same time women writers established publishing houses and bookshops, no longer reliant on the male publishers (Dann, 1985). These responses in New Zealand and elsewhere came as a reaction to the treatment of women during the period of this study 1945 to 1970 and changed the position of women writers.

Another more recent event which made me want to write this thesis was the twentieth anniversary of Keri Hulme's The Bone People winning the Booker Prize, the only New Zealand book to have done so. A symposium was held to celebrate this achievement at Victoria University and apart from myself, none of the male university literary academics, VUP writers or other male writers in the Wellington region turned up to honour Hulme. When I asked Lydia Wevers, one of the conference organisers, what she thought about this situation she told me that they had certainly been invited. As, despite this, they did not attend, I conclude that the silencing of the 'other' (in the case of women, half the population) continues despite such international success.

\section{Why write this thesis in GWS}

I decided to write this thesis in the Gender and Women's Studies Department of Victoria University as it is a department better suited to understanding the issues involved for individual women writers through a feminist critique, than through a narrowly focussed 'literary' study which another department might demand. For it is that very 'literary narrowness' and subjective viewpoint of 'good literature' that has, perhaps, robbed many of the women writers of their 
proper status and contribution to the New Zealand literary canon. I am aware of differing views on men undertaking a study of what may be seen as a 'feminist', study but I make no apologies for this. As a man interested in literary subjects and possessing a sense of fairness I feel qualified to undertake this study. I feel that many of the women covered by this study were treated badly and this is my response. While I agree to a certain extent when Reinharz cites Mary Daly's claim 'that men can support feminism but cannot be feminists because they lack women's experience' (Reinharz, 1992: 14), I feel that a more apt expression of what I am attempting is described by Renate Klein's belief that 'we cannot speak for others, but that we can, and must, speak out for others' (Klein in Reinharz, 1992: 14).

While there has been a body of published work on New Zealand women writers in recent years, including those of the period I am investigating, such work is to a greater or lesser extent deficient in feminist critique. It does, however, provide the raw material for such a critique. Throughout the thesis I also investigate the sociological, economic, class, racial, and cultural pressures which either hindered or encouraged women writers, including norms related to gender division of labour within families and their impact on women's opportunities to put writing at the centre of their lives. In particular, several of these issues are investigated in Chapter 3 which addresses the social and historical themes. The issues relating to Māori women writers are discussed in Chapter 8.

I investigate the apparent marginalisation of women writers by male writers, critics and publishers. One example I will investigate in some depth involved the poet Ruth Gilbert. In 1957 the literary magazine numbers published a letter by Willow Macky in which she 'criticises the critics' of the New Zealand literary scene, as will be discussed in the study of the poets in chapter five. Gilbert, whose work sparked this controversy, will be examined in some detail. There were also some interesting marriages between creative people during this period. For example, poets James K. Baxter and J.C. Sturm, Meg and Alistair Campbell, and artists Anne and Colin McCahon.

I examine the work of Māori women writing in English during the period, in particular the works published in $\mathrm{Te}$ Ao Hou, including waiata and reviews. 
For example, J.C. Sturm was writing book reviews and Arapera Blank short stories. The waiata of women such as Rangi Dewes and Erihapeti Murchie, whose husband has given me access to her unpublished waiata, and the influence of Māori women's writing on cultural and sociological subjects is also relevant during this period and will be explored. Having access to unpublished written material has allowed this thesis to discover women writers' stories that may have gone unrecognised. In Murchie's case it is doubtful that her writing would have been accessible beyond her whānau. In the case of Renée and Karen Butterworth, had I not encouraged them to contribute their stories these may have not have become available until either of them wrote a memoir. I hope this will encourage them to do so.

I also investigate lesbian writing, whether identified either explicitly or implicitly, among the women writers of the time. Aorewa McLeod reminds us: 'Mander, Marsh, Escott, and in the art world Hodgkins, all lived before second wave feminism and gay liberation came to New Zealand in the early 1970s and made lesbian visibility possible' (McLeod, 2001: 59). In this chapter I argue that writing by women that dealt with lesbian themes was unacknowledged as such by the publishing and critical literary establishment; where acknowledged, these writers were not published or recognised in the 1945-70 period, but vanished from the lists. The reason that most of the lesbian writers in this chapter are from outside the 1945-70 period highlights the fact that lesbian writing and lifestyles were not written of during this time.

Sections of the thesis will examine the statistical data and bibliograpical work compiled on New Zealand writers of the period in order to assess how many women were published compared to men. While I came to this subject through the avenue of my own research, the section by Heather Murray in The Oxford Companion to New Zealand Literature on the 'New Zealand Writer's Conference, 1951' intimates much the same ideas. Murray writes:

regardless of which men were in or out [of favour], nearly all women were out. Between Author's Week 1936, which celebrated a mainly female creative literature, and 1951, women's writing had been demoted by the middle generation of male writers as trivial, irrelevant or illdisciplined. As literary arbiters, editors (Brasch), critics (Bertram, Curnow, Brasch), publishers and printers (Glover and Caxton), and 
compilers of influential anthologies (Curnow), this generation shaped the course literature was to take until the 1970s. Only then did women's writing begin its hard-fought move back in from the margins (Murray, 1998: 406).

Informing the thesis as an undercurrent will be A Room of One's Own by Virginia Woolf, which imagines Shakespeare having a sister who is also a gifted writer. Woolf writes of the short-lived attempts of 'Judith' Shakespeare to employ her talents in the same way as her famous brother (Woolf, 2000). I think about the New Zealand women who could perhaps have been writers during my period; the women I have included in my study did at least manage to get published - there are undoubtedly others, who, like Judith Shakespeare, did not even manage to get started.

While it is outside the scope of this work it is important to note here that most of the New Zealand women writers who were successful during the period 1945-70 found success overseas. The next chapter details the methodology and literature review for this thesis, followed by chapters 3 and 4 that look at the social, historical, and literary backgrounds of the issues facing women writers leading up to and of the period 1945-70. I then consider specific genre, and individual writers within them to provide evidence from their writing to illustrate their situations. I conclude this introduction with a quote from Woolf in which she states the situation women are often perceived to be observed from and which view underpins my thesis:

but women feel just as men feel; they need exercise for their faculties and a field for their efforts ... they suffer from too rigid a restraint, too absolute a stagnation, precisely as men would suffer; and it is narrowminded in their privileged fellow-creatures [that is, men] to say that they ought to confine themselves to making puddings and knitting stockings, to playing on the piano and embroidering bags. It is thoughtless to condemn them, or laugh at them, if they seek to do more or learn more than custom has pronounced necessary for their sex (Woolf, 2000: 89). 


\section{Chapter 2}

\section{Methodology/Literature Review}

\section{Feminist methodology}

The methodology underpinning this thesis is informed by feminist theory. I examine the views expressed at the time by the women writers themselves and accord their views the status of material evidence rather than dismissing these as subjective opinion. My study also draws upon a range of feminist literature and ideas. In particular, my approach is informed by the ideas of Shulamit Reinharz (1992), Gayle Letherby (2003), Adrienne Rich (2001) and Linda Tuhiwai Smith (1992). My work is essentially an attempt to 'salvage from the wreck' (Rich) an understanding of an era in our literature in which many women writers were unacknowledged simply because they were women.

Feminist theory is concerned with sexism in any given society, and asks how does the theory describe and understand the position of women in society? What are the sources of women's oppression and who gains from negative stereotyping of women? Researching a wide range of feminist research methods Reinharz (1992) explains the relationship between feminism and methodology and challenges existing stereotypes. She concludes there is no one correct feminist method, but rather a variety of perspectives and argues that such a diversity of methods has been of great value to feminist scholarship.

Reinharz identified ten themes as relevant to feminist research, suggesting that feminist methodology is the sum of these feminist research methods. Of the ten themes Reinharz identifies, the most appropriate to my thesis are:

2) Use of a multiplicity of research methods.

4) Feminist research is guided by feminist theory.

5) Feminist research may be trans-disciplinary (for example: social history, literary studies etc). 
7) Strives to represent human diversity.

8) Includes the researcher as a person [ie my background as a writer, publisher etc].

9) Attempts to develop special relations with the people studied [eg Renée, Butterworth, Frame, Sturm, Campbell etc], (Reinharz, 1992: 240).

Australian feminist writer Renate Klein states: 'An emerging postulate for feminist - is using a variety of methods to generate multifaceted information' (Klein in Reinharz, 1992: 197). Among the 'Multiple Methods' suggested by Reinharz that are relevant to the literature based thesis I am presenting are 'Commitment to Thoroughness' and 'Integration of the Personal and the Social', which in my case also includes interface with the literary information of the women's own writing, and the 'Quest Image' which entails the 'quest' for the truth behind the 'known facts'. This approach is particularly pertinent to my way of 'looking' at the subject due to my own involvement in literature as a writer and publisher who is seen as being outside the literary 'establishment'.

Feminist literary criticism looks at literary works and their creators differently from much traditional criticism which has tended to see works of literature in an hierarchical, comparative, judgemental and what claims to be 'objective' manner. However, as Elaine Showalter points out in her introduction to her edited collections of early feminist criticism:

Since the late 1960s, when feminist criticism developed as part of the international women's movement, the assumptions of literary study have been profoundly altered. Whereas it had always been taken for granted that the representative reader, writer, and critic of Western literature is male, feminist criticism has shown that women readers and critics bring different perceptions and expectations to their literary experience, and has insisted that women have also told important stories of our culture (Showalter, 1985: 3).

While Showalter is an American academic, the fact that New Zealand generally comes under the banner of 'Western culture' means that her analysis of the situation of women's writing can be adapted to the New 
Zealand cultural and literary climate. The period this thesis deals with ends roughly at the time Showalter regards as being 'part of the international women's movement', that is the late 1960s and early 1970s, which illustrates the relevance of that change and coincides with the loosening of the traditional and sexist attitudes which I argue dominated literary and cultural life for New Zealand women writers before the 'liberation'.

In her essay, 'Feminist Criticism in the Wilderness', Showalter investigates the question also posed by many of the New Zealand women writers in this study, that is: what exactly is feminine or women's writing? She discusses Virginia Woolf and Hèléne Cixous, who take differing positions to this question. Woolf discusses feminine perspective:

A woman's writing is always feminine, it can't help being feminine; at its best it is most feminine; the only difficulty lies in defining what we mean by feminine (Woolf in Showalter, 1985: 247).

Cixous thinks it cannot be defined:

It is impossible to define a feminine practice of writing, and this is an impossibility that will remain, for this practice will never be theorized, enclosed, encoded - which doesn't mean that it doesn't exist (Cixous in Showalter, 1985: 247-8).

Much of my argument inherent in this thesis revolves around the question of how so many of the women writers in New Zealand in the period 1945 to 1970 also 'did not exist' in terms of the literary world's recognition.

Gayle Letherby argues that there is no such thing as a 'feminist method' but rather a 'feminist methodology' - one which is respectful of respondents and acknowledges the subjective involvement of the researcher (Letherby, 2003: 5), using the word ' $I$ ' rather than 'One'. New Zealand academic, Alison Jones, in discussing the objective versus subjective approach to academic writing, argues that the orthodox view on knowledge has been changed by postmodernists and feminists, and points out that the ' $\mathrm{l}$ ' is central and people's accounts of the world are constructions, made up from the language, meanings and ideas historically available to them as the ' $l$ ' (Jones, 
1992: 18). This is significant to my approach, due to my own involvement in the literary world and motivation in writing this thesis.

The concept of 'Otherness' is discussed in this thesis and suggests that the lack of proportion in power relationships is central to the construction of 'otherness'. Only the dominant group is in a position to impose the value of its particularity and to devalue the particularity of 'others' while also imposing discriminatory measures on the 'Other'. French existentialist philosopher Simone de Beauvoir's example, that if the Other of 'Man' is 'Woman', and if 'Man' is the dominant group, this indicates that women's secondary political, legal, and economic status relative to men, are evident in myths such as the Biblical tale of creation where God creates Adam first and Eve second, as Adam's companion (de Beauvoir, 1952).

According to de Beauvoir, male-dominated cultures represent humanity as male and define woman as relative to man. Woman, while not a minority numerically, is the 'Other', an object reflective of men's desires and fears. Women, as an oppressed caste, are forced to accommodate themselves to this identity, denying their own freedom. The domestic confinement of women can be analysed as reducing the woman to her domestic role, that patriarchal society creates and reproduces gender inequality. In The Second Sex de Beauvoir argued that women must counter these myths with phenomenological descriptions of their own lived experience and challenge their secondary status in a political struggle for women's liberation. In this she was prophetic, and by the end of the period covered by this thesis, the late 1960s and into the 1970s and beyond, third wave feminism had brought de Beauvoir's ideas and ideals into reality.

Otherness also equals a form of binarism: that is the opposition of colonist/native or White/of Colour, Man/Woman. For example, in his book Orientalism, Edward Said (1978) states that the West/Orient duality encompasses all of the components of Otherness. The Oriental is characterized by his barbarity, his savageness and his race. The Orient is the geographical fiction that gives him geographical basis. Orientalism is the discourse through which the West constructs the Otherness of the Turks, Moroccans, Persians, Indians, Japanese: all reduced to the same 
stigmatizing stereotypes, and thus gives itself an identity in opposition to them.

However, taking Said's ideas further, not all forms of Otherness are fully (or even mainly) geographical in nature. Women, homosexuals and the insane, all major figures of Otherness in the West, owe their stigmatization to something other than their location. Aspects of these forms of 'Otherness' are discussed further in this thesis. For example, in this chapter the Māori writer Linda Tuhiwai Smith is concerned not only with colonialism and its effect on Māori traditional society, but how Otherness in the racial sense does not necessarily sit well with Otherness in the sexual sense, that is in the context of Pākehā feminism. The Otherness of Janet Frame is discussed in Chapter 6 and the particular form of Otherness that is lesbianism is studied in Chapter 9 in relation to lesbian writers in New Zealand.

Dominated groups in society are Others precisely because they are subject to the categories and practices of the dominant in-group and because they are unable to prescribe their own norms. However, women represent a particularly singular type of Out-group. Not because they are numerically less in number than the dominant group, but because of their sex alone. Outgroups cease to be Others when they manage to escape the oppression forced upon them by in-groups, in other words, when they succeed in conferring upon themselves a positive, autonomous identity. It is, therefore, one of the objectives of this thesis to facilitate this if the women writers of the 1945 to 1970 period in New Zealand can be considered in terms of their Otherness to New Zealand male writers of the time.

As a writer of Māori and Irish descent I have a particular interest in Māori women writers. However, any chapter on Māori women writers from the period I am writing about will have difficulties, due to the paucity of written and published literature available. Also, in adopting a feminist critique it will be seen that feminist methodologies and studies arose from the thinking of 'white women', which may not necessarily fit into a Māori perspective. As Māori academic, Tuhiwai Smith, points out 'when Māori women control their own definitions, the fundamental unit of identity which can make sense of different realities lies in whakapapa' (Smith, 1992: 39), and this 'reality' can 
often be in conflict with theoretical ideas about how things should be. The position of Māori poet J.C. Sturm provides one example of the difficulties faced by Māori women writers during this period.

Postcolonial literature often involves writings that deal with issues of decolonization or the political and cultural independence of people formerly subjected to colonial rule. It is also a literary critique of texts that carry racist or colonial undertones, as similarly feminist literary critique identifies sexist undertones. According to New Zealand academic, Patrick Evans: 'The New Zealand that began to thaw and stir in the early 1970s had been monocultural for more than 50 years' (Evans, 2007: 16). It could also be said that the literary world in New Zealand from the 1940s to the 1970s could be described as having been 'monosexual' and this thesis is an attempt to draw that aspect of the New Zealand 'blokes' literary culture out and to ask: where are the women, and why aren't they there?

Postcolonialism and feminism both investigate particular instances in human culture where one conceptual thread that links all its various interpretations is the rejection of universalism, which refers to the notion of a unitary and homogeneous human nature. Angeli R. Diaz (2003), for example, writes that particular to feminist theory is postcolonial theory's rejection of universalism that resonates with the Third Wave feminist agenda of inclusiveness. So, while terms like post-modern, post-colonial, multiculturalism and others were not in wide use during the 1945-1970 period they do impact in retrospect.

My approach is also informed by feminist economic and social theory based on a Marxist feminist and materialist framework. I do not seek to evaluate the texts from the perspective of literary theory, rather I ask what were the circumstances of their production, that is, what were the constraints inhibiting the ability of the women writers to produce work during the period, and who owned the means of producing books, that is, who owned the press, thus controlling the so-called freedom of the press. For example, my approach is informed by the insights of feminist economist Prue Hyman (1994). Thus, I investigate how women's economic and social status was affected by the pervading gender and family norms of the time and how this 
influenced their ability to firstly produce their work and then, to get it published by the owners of the publishing houses at the time. As Terry Eagleton writes in Marxism and Literary Criticism:

Literature may be an artefact, a product of social consciousness, a world vision; but it is also an industry. Books are not just structures of meaning, they are also commodities produced by publishers and sold on the market for profit ... Critics are not just analysts of texts: they are also (usually) academics hired by the state to prepare students ideologically for their functions within capitalist society. Writers are not just transposers of trans-individual mental structures, they are also workers hired by publishing houses to produce commodities which will sell (Eagleton, 1985: 59).

I also examine the economic concerns of the time in relation to the publishing and retail book industry, informed by feminist economic theory. One of the issues for feminist publishers was whether to publish for a mass market or not. It will be noted that several women in this study wrote to make a living, whether as journalists or writers of popular fiction, and this was often in conflict with those who wanted a more philosophical-theoretical approach to women's literature. For example, in a chapter on 'Women's Publishers', the authors of Rolling our own quote the 'Onlywomen Press':

In order to create a Women's Liberation Movement reality, we need discussion and the development of political analysis unhindered by patriarchal values. We need a means of establishing our own culture (Onlywomen Press in Cadman, Chester \& Pivot, 1981: 29). [the authors then continue] Feminist publishing, more than any other aspect of the book production process [including the writing], seems to epitomise most clearly the problems and choices which face feminists confronted with a society which is both patriarchal and capitalistic (Cadman, Chester \& Pivot, 1981: 29).

Thus, feminist publishing is faced with two of the classical Marxist propositions: who owns and controls the means of production, and who benefits? Most of the women in this study had little choice. If they wanted to write and sell books they had to go with the big commercial companies, but as Cadman, Chester and Pivot point out, this approach: 
almost certainly means watering down the content of the books, and having decisions about style of presentation, publicity and promotion and so on decided for them. The main advantage is that their books will, potentially, have a wider audience, since larger companies have greater resources (Cadman, Chester \& Pivot, 1981: 41).

This certainly had ramifications for the writers of romance and so-called light fiction, several of whom reacted with self-deprecating humour; Rosemary Rees, for example, ruefully pointing out that she was New Zealand's best selling author.

Metaphorically, this underlying conundrum can be illustrated by a case study of a well-educated and motivated woman, 'Betty', in a feminist account of women and the economic and social change brought about by World War II, Rosie the Riveter Revisited. Sherna Gluck describes the situation of women in her own country, some of which is relevant when considering pre1970s attitudes towards women experienced by many of the New Zealand women writers featuring in this thesis. Gluck writes of Betty:

She certainly chafed at any suggestion that she was less able because she was a woman. But women like Betty have had few outlets to express their anger [at being treated less than equally because they are women]. Their 'premature feminism' could not take root without a social movement to support it (Gluck, 1988: 105).

The term 'Rosie the Riveter' was first used in 1942 in a song of the same name written by Redd Evans and John Jacob Loeb. The song was recorded by many artists and became a nationwide hit in the U.S.A. It tells the story of 'Rosie', a tireless assembly line worker doing her bit for the American war effort. While real-life 'Rosie the Riveters' took on previously male dominated jobs during the war, women in the U.S.A. were often expected to return to household work when the soldiers returned from overseas (Rupp, 1978).

Similar occurrences took place in post-war New Zealand after World War Two. For example, in Brian Edwards' biography of New Zealand Prime Minister, Helen Clark, Edwards points out that for Clark's mother:

There was heavy competition for jobs. Servicemen who had returned from the War and gone to Training College were given the first option on teaching positions as they came up. Margaret [Clark's mother] found it 
difficult to find a job anywhere near home and she and her friends applied for positions in the most unlikely places (Edwards, 2001: 32).

This is one example that illustrates some of the difficulties that many women faced gaining employment after the war, a situation I see as affecting many women writers of the post-war period. Though there were organisations campaigning for women's equal rights during the period between what is regarded as first and second wave feminism (see, for example, Dale Spender's There's Always Been a Women's Movement this Century) it would be difficult to argue that such groups had the broad grassroots appeal of post-1970s Women's Liberation groups, or large events such as the United Women's Conference (see, for example, Christine Dann Up from Under, 1985).

Groups such as the Equal Pay Campaign and the efforts of unionists to improve working conditions for women, and organisations like Family Planning seeking to limit excessive pregnancies and the promotion of contraception, were not broadly based. Therefore they were unlikely to attract large numbers of women or to directly provide women with the sense of solidarity and support that developed in the post-1970s period. In Chapter 7 Butterworth's contribution also touches on these issues in relation to the public service and brings them into context. The relevance of the pre-feminist 1970s and the lack of 'a social movement' to support the women writers who are investigated in this study is also a recurring theme throughout the years 1945 to 1970 .

My main source of information for the thesis was through work already written, some published, some in private collections. As a writer, bookseller and publisher I have built up a network of contacts in the New Zealand literary world which gave me access to material not available in the general world of books. In particular my thesis is informed by the works, letters and articles available through published and unpublished sources written by the women and men of the time to help provide an understanding of the situation for women writers during the period. I also make use of collections held in Wellington public institutions, including The National Library, the Alexander 
Turnbull Library, The Beaglehole Room, of the Victoria University Library, and Archives New Zealand.

\section{Literature Review}

Some relevant theses examining New Zealand writers are Kai Jensen's on the 'masculinists' tradition in New Zealand writing, which in a way can be seen as the 'flip-side' to my own study. Published in 1996 under the title Whole Men (based on his PhD thesis) Jensen's writing on the subject of the male writers has been invaluable for finding the prevailing attitudes of many of the men towards women in the New Zealand literary world during much of the period covered by my thesis. Tim Shoebridge's PhD thesis on Helen Shaw deals centrally with the period 1945-1970, exploring the texts and contexts of her life and work and is therefore relevant to my study.

Another is the $\mathrm{PhD}$ thesis by Anne Else titled On Shifting Ground (Victoria University, 2006), which tracks her own development as a writer alongside her gradual awakening as a feminist. Else sees women's autobiographical writing as a previously unacknowledged mode of making visible formerly invisible subjects. This I regard as an apt expression of the approach that I take to much of the women's writing during the period of my study. That is, to make visible formerly invisible subjects.

Kimberley Koza (1988) in her PhD thesis looks at developments in fiction by women writers who give voice to previously undocumented and unacknowledged histories by portraying representative female characters. This includes, among others, Māori writers like Patricia Grace, whose work is compared and contrasted with work by Alice Walker, Joy Kogawa and Kamala Markandaya, all of whom are considered in relation to how they define or redefine themselves culturally, sexually and historically. Koza concludes that despite personal differences all these writers do share common experiences because they are women.

Linda Tuhiwai Smith in her essay on Māori women discusses the difficulties involved in using universal metaphors such as 'Otherness', which 
were invented by white feminists, in discussing Māori concepts of women's experience. Smith states:

While white feminists may help to gain insight into "Otherness" at one level, at another level these forms of feminism may perpetuate otherness further. This tension has made it extremely difficult to reconcile the realities of Māori women's lives with existing feminist theories (Smith, 1992: 34).

While it is beyond the scope of my thesis to go deeply into this debate it is important to acknowledge the often negative view of Māori women portrayed by the media in Pākehā society. But Smith indicates the positive traditional role of women in Māori society: 'Women were explorers, poets, chiefs and warriors; heads of families; founding tipuna or ancestors of various hapū and iwi. Their deeds were remembered in waiata and Whakataukii' (Smith, 1992: 35). Smith then analyses the different experiences of Māori men and Māori women under colonisation, stating that from the earliest times the colonisers were in the first instance white men dealing with Māori men. Writing in 1992, Smith concludes that:

The last twenty years [since the 1970s] has seen the emergence of Māori women as something more than a mere social category. Māori women are now part and parcel of the economic and political reality of society ... this movement has enabled Māori women to become a critical part of the struggle for rangatiratanga ... on that basis alone Māori women need to act (Smith, 1992: 49).

However, it is interesting to note that the poet, J.C. Sturm, was aware of the trend described by Smith nearly twenty years earlier, when she wrote in an article in Te Ao Hou: 'if the Māori women today really have more vigour and initiative than the men, well, good luck to them!' (Sturm, 1954: 8). The bicultural nature of Māori-Pākehā relations in New Zealand and their problems in relation to feminist theory also interface with a wider discussion of multiculturalism and feminist thought. Feminist writer Katha Pollitt casts doubt on whether feminism and respect for cultures can ever be reconciled. Pollitt states: 
Feminism and multiculturalism ... are very far apart. In its demand for equality for women, feminism sets itself in opposition to virtually every culture on earth. You could say that multicuralism demands respect for all cultural traditions, while feminism interrogates and challenges all cultural traditions (Pollitt in Saul, 2003: 289).

Jennifer Saul in her book Feminism: Issues and Arguments is concerned that feminism might contribute to the loss of certain cultures altogether. Saul writes:

Surely, one might suppose, this is not compatible with respect for such a culture. The thought behind this is that a culture may contain features that are so crucial that any alteration to them would effectively destroy the culture (Saul, 2003: 289).

This aspect of feminism is what Smith was concerned with when explaining the significance of whakapapa, whānau, hapū and iwi, and how Māori women have to address their own feminism within Māori culture, and not the universalism of Western thought feminism. However, some feminists find this 'particularism' difficult to deal with, especially when part six of Reinharz's ten feminist research ideals is aimed to 'create social change' (Reinharz, 1992). As Rosemary Tong writes in a discussion on universalism:

... if the idea of difference makes it impossible for women in one culture to communicate with women in another culture, global feminists might as well forget their plans to build a new world order. Such an order is neither viable nor welcome if people are so different they cannot even make sense of each other's words (Tong, 1998: 238).

Margot Schwass' MA thesis 'Between Two Worlds: a study in migrant writers in New Zealand' (1986) considers the work of Amelia Batistich (19152004) and Yvonne du Fresne (1929-). This thesis and the PhD thesis by Nina Nola 'My two countries firmly under my feet' are explorations of multi-cultural identity in the fiction of Amelia Batistich and Yvonne du Fresne, and show how earlier migrant women writers were particularly invisible and unrecognised within the mainstream publishing industry.

Helen Rickerby, in the journal Endnotes (Rickerby, 2001: 38-42), discusses the role of publishers as gatekeepers to the production and 
preservation of knowledge, highlighting that they have historically been male and tended to exclude women. She discusses the rise and recent decline of feminist publishing, and suggests women should publish on the Internet. Laurel Bergmann provides an overview of writing and publishing in New Zealand in the seventies, eighties and nineties in Hecate (Bergmann, 1994) especially in relation to the development of women writers. She considers the emergence of Māori women, both heterosexual and lesbian, lesbian writing generally and the effect of large mainstream bookshop chains (for example Whitcoulls, Borders etc) on the purchase and distribution of non-conventional literature.

When poet and feminist philosopher Adrienne Rich re-read some of her prose writings for republication she reported that many earlier pieces seemed to belong to a long vanished era - 20 to 30 years ago, which of course it was. However, she chose to include these pieces as background, explaining that: 'I 'used myself' to illustrate a woman writer's journey ... in 1971 this still seemed a questionable, even illegitimate, approach, especially in a paper to be given at an academic convention' (Rich, 2001: www. Adriennerich. hpg.ig.com.br/resources). Informing my study is Rich's 1973 collection of poetry Diving into the Wreck which is a metaphor for regaining lost female knowledge, especially written work never published or now out of print.

Aorewa McLeod, scholar of New Zealand women's literature, discusses three New Zealand novelists, a poet, and a painter, whose identities as lesbians have been obliterated in biographies and critical commentaries. She considers whether the small and largely mono-cultural New Zealand literary and artistic scene made both coming out and being identified as a lesbian more difficult than in Europe or the United States. While it is impossible to 'ghost' an outspoken activist like Ngahuia Te Awekotuku, McLeod concludes that even in the 1990s 'ghosting', an expression she takes from the work of Castle (1993), the lesbians of the past is still prevalent (McLeod, 2001: 61).

Alison Laurie's PhD thesis, 'Lady-Husbands \& Kamp Ladies' (2003), considers the work of several pre-1970s writers and artists, some from my period, including the poet Ursula Bethell. Writers whose work dealt with lesbian themes were often not selected for mainstream anthologies during 
my period, so Laurie and McLeod's work has been relevant to my thesis. ARD Fairburn wrote his notorious essay 'The Woman Problem' which was published in 1967 and reflects his anti-homosexual bias. I discuss his essay in Chapter 5.

\section{Selection of the Women Writers}

Women selected for study in this thesis could number many more if it were possible to research all those women who had hoped to write, but were prevented from doing so by their own lack of confidence or lack of encouragement by others. Even attempting to include all women who submitted work to publishers or magazines, and who were rejected, would produce large numbers. This would be true of some male writers too, of course, but it is not the intention of this thesis to examine their restraints.

In selecting women for study I needed to choose what could be regarded as a representative group, both demographically and in terms of their preferred genre. I also needed to select women where some evidence was available in their published or unpublished work of the restraints placed upon them as women writers during the period and Butterworth's experiences are pertinent here. Obviously there are many absences, as this thesis cannot provide an all-encompassing survey, including every published or intending woman writer during the period. I have not included immigrant writers like Batistich, as their situation has been well covered by Nola and Schwass in the theses mentioned above. Recent Pacific Island writers like Sia Figiel and Makerita Urale do not fall into the time-line either.

I discuss the work of some of the successful writers during the 1930s, and into the 1950s, such as Nelle Scanlan, Mary Scott and Joyce West, in the section on novelists who continued to sell books in large numbers. The appendices of the work by Eden, Quentin, and Marsh attest to the popularity of their writing, particularly overseas, and is the reason for highlighting them, as the bibliographical work on them is not freely available and makes an extremely valuable contribution to this thesis and knowledge in this field generally. 
The selection I made does not, as far as I am aware, omit any major writers and is as full as I could make it, although it cannot claim to be a completely comprehensive survey of the period. It provides ample evidence of my main argument, which is the under-representation and trivialization of women writers of my period, together with a detailed discussion of the factors accounting for this under-representation and trivialization. I outline the careers of a number of women poets and novelists, including some detailed case studies. I also examine the particular issues facing Māori and lesbian writers. It was the lack of ready data, especially for Māori women, that lead me to approach the Murchie whānau and Renée for their contributions. I did not know what they would have by way of new information, but as it turned out both proved valuable.

Some of the women writers 1945-1970 who have been overlooked or not given sufficient credit or acknowledgement in the main literary discussions of the period include Rosemary Rees, Dorothy Eden, Mary Scott, and Sylvia Ashton-Warner; Janet Frame being a notable exception. Women poets were also under-acknowledged until much later. For example, Harvey McQueen's 1993 anthology has an article 'The Poetry of Settlement in New Zealand 1852-1914' which features Mary Richmond. For more general information on Mary E. Richmond I draw upon Frances Porter's article in the Dictionary of New Zealand Biography. In Late Harvest Dr Nielsen Wright lays out as much information as he could find relating to her poetry.

Restricting herself to Pākehā experience, Lynley Cvitanovich writes very much along the lines of a current feminist critique about two women writers, one of whom, Jean Devanny, lived into my period. Devanny published from 1926 to 1949, but lived in Sydney after 1929. Of her 16 novels, the last 9 were set in Australia, and of those only the last two were published later than 1944. She is relevant, but geography excludes her to a large extent. Shoebridge's thesis explores the texts and contexts of Helen Shaw's life and work as a woman writer facing and suffering the negative consequences of the mainstream New Zealand literary scene at a time of prevailing lack of interest in 'feminine' writing. Shaw's strength of character and circumstances gave her more time and energy to write than many of her male 
contemporaries, therefore Shoebridge's thesis, and Shaw as a writer, are relevant to my study.

In Chapter 3 I provide an account of the social and economic background and type of society the women in my time frame experienced. What expectations and constraints were they under and how did these impact upon women who may have wanted an artistic or literary career? In her article 'What do feminist critics want?' American critic Sandra M. Gilbert, discusses women who want to follow their own way and not be tied down by someone else's view. She explains:

Metaphorically speaking, they define those of us who do this kind of work [academic writing in this case] as what the Victorians used to call 'redundant women' - women, said the social critic W.R. Greg, who in place of completing, sweetening, and embellishing the existence of others are compelled to lead an independent and incomplete existence of their own'. Defining us as 'redundant', moreover, they devalue our work to students, discourage our admirers, dishearten our junior colleagues, and force us into destructive competition with one another for a few token jobs (Gilbert in Showalter, 1985: 39).

Gilbert writes of academic women writers in the U.S. during the 1980s; however, these attitudes had persisted for decades. This thesis investigates prevalent attitudes towards women writers of fiction and poetry and intellectual women generally in the New Zealand literary climate of the 1940s, 1950s and 1960s. Gilbert claims that the attitudes of the Victorian era were still relevant in the later half of the $20^{\text {th }}$ Century.

The resources I have used to illustrate this study are the published and unpublished writings by and about the selected women. As some of the recent writers are personal friends whose work I have published and in keeping with feminist ideas of the use of the 'personal experience', I was able to request that they write special pieces for this study and perhaps for later publication. In the next chapter I discuss the social and historical factors determining such attitudes to women and women's rights up to and including the time covered by this thesis. 


\section{Chapter 3}

\section{Social and Historical Background Post WW1}

This chapter discusses briefly the historical and economic factors affecting women in New Zealand from 1918 to the 1970s. How did these elements encourage or discourage the women of the time who wanted to become writers and artists? Were women, given their roles in the home, and the expectations on them to be mothers, wives and or dutiful daughters, able to find time, space, and financial independence to enable them to write? These points will be dealt with further in the chapters on the novelists and poets.

In New Zealand before the Married Women's Property Act of 1870, designed to protect deserted wives, anything a woman earned or owned was her husband's (Sutch 1974). Married women up to this time were classed legally as minors together with children and lunatics, originating from the English legal system where, as the jurist Blackstone stated, the 'legal existence of the woman is suspended during marriage' (Blackstone in Sutch, 1974: 13). Sutch notes of married women that under New Zealand law:

Her chattels became available to her husband and her lands were at his disposal during their joint lives and anything a married woman acquired during her marriage by gift, inheritance, or earnings, went to her husband (Sutch, 1974: 85).

Because New Zealand law was synonymous with British law at this period an interesting aspect of inter-racial marriage occurred. Sutch cites Patricia Grimshaw who records:

the report in Parliament that in 1881 Māori women, who as women had the right to own land [under tikanga Māori], refused to marry Europeans because, by doing so, they would then become subject to English law (Sutch, 1974: 85).

Despite legal reform, attitudes towards women and finance had not changed all that much by the 1960s. For example, Robyn Du Chateau (1997) explains that when her parents separated she went to the lawyer with her mother who 
told her she would not get anything, that she would have to rely on her husband's compassion. As Du Chateau writes: 'She wasn't allowed to keep anything - the paintings, the furniture, anything at all. Like she walked in and she walked out - she kept her clothes' (Du Chateau in Tolerton, 1997: 60). Such were the social and legal mores under which many of the writers this thesis deals with had to live by and work around.

With the social and political upheaval caused by World War One and the worldwide flu epidemic that followed in 1919, the gains of any of the women's organisations towards equality seemed to take a step backwards. Alongside a 'boys back from the war' bias being prominent in employment generally, there were changes in technology that favoured male rather than female employment. For example, there appears to have been a deliberate 'rooting out' or downgrading of women's positions in the New Zealand Public Service throughout the 1920s. Economist Prue Hyman observes:

All public servants had reduced conditions in this period of intermittent recession, but women were disproportionately downgraded ... [for example] Women were 16.4 per cent of Post Office employees in 1921, but this had reduced to less than 10 per cent by 1929, with only lowpaid, repetitive work available as compared to the higher-skilled postmistress positions filled earlier (Hyman, 1994: 83).

Throughout the 1920s and into the 1930s a concept of 'the family wage' was employed to determine wage rates through the whole economy of New Zealand. Hyman states that:

The family wage principle had been enunciated by the Arbitration Court, which in 1922 argued that: "The material requirements of normal life, for the average adult male, includes provision for his family ... In the case of the wage-earner, this right can be effectuated only through wages; therefore the adult male labourer has a right to a family living wage" (quoted in Iverson, 1987). A minimum wage for women was not set by the court until 1937, and then at only 47 per cent of the male rate (Hyman, 1994: 83).

Hyman also notes that the Labour Government, headed by M.J. Savage, during the Depression years of the 1930s continued the policy of the 'family wage' for men as set out in 1922, regardless of whether individual men or 
women wage earners had dependants. This idea of the man's wage being the norm for families and society became the set concept throughout the period of the 1920s and into the 1930s.

Another international issue that was of concern and contention during the inter-war years was that of married women's nationality. Until the 1920s the legal status of women was that their nationality was deemed to be the same as that of their husbands. An interesting illustration of the absurdity of this policy is the case of Miriam Soljak cited in an essay on women and nationality by Dorothy Page (1986). Page tells of Soljak who married an Austro-Hungarian who had already been in New Zealand for twenty years, but who in 1917 had to register as an 'alien' and as a result his New Zealand born wife Miriam Soljak also had to register as an alien. Page points out that this woman was:

\begin{abstract}
A New Zealander through and through, she taught before and after her marriage in sole charge Māori schools, spoke Māori fluently, and was concerned for the welfare of the Māori people [indeed, this is far more than could be said for most Pākehā New Zealanders] ... In 1919 [a year after World War One] although (as her daughter put it) she was "a good Catholic matron expecting her seventh child", she refused point blank to register as an alien; and when at last she was forced to capitulate or go to prison, she insisted that the Tauranga police constable endorse the certificate with the words "I certify that the applicant has registered under protest" (Page in Brookes, 1986: 165).
\end{abstract}

During the 1920s and into the 1930s pressure grew among women's groups to have this unfair situation rectified and after the Labour Government was elected in 1935 some progress was made to enable women citizens of New Zealand to differentiate between themselves and their husbands with regard to nationality. The situation was somewhat different in England and other Commonwealth countries. Even after she divorced her husband in the late 1930s Soljak was forced to keep her status as an alien national:

She travelled to England in 1937 on a British passport marked 'New Zealand born, wife of an alien, now naturalised' and was obliged to report to Scotland Yard every three months ... the New Zealand government was by no means happy with this restriction on its nationality legislation ... At the meeting of Dominion Prime Ministers [in 
1935] and at the 1937 Imperial Conference, it was New Zealand and Australian delegates who set the pace in the discussions on women's nationality ... At the end of the [Second World] war the Commonwealth chose to replace the concept of a single British nationality with that of separate Dominion nationalities embodied in interlocking Nationality Acts ... Thus New Zealand asserted its independence as a nation from Britain, and New Zealand women asserted their independence as citizens from men (Page in Brookes, 1986: 174,175).

Historian Michael King notes, when discussing art and writing during the decade after World War One, that much of novelist Jane Mander's work was written overseas. King writes:

Those of her books which reached New Zealand were, like the later work of Frances Hodgkins, reviewed with hostility, largely because of what was regarded as 'immoral' content (King, 2004: 320).

Mander's first novel, The Story of a New Zealand River, first published in 1920, was set in a Northland timber-milling settlement and focuses on the differences between two generations of women. It challenges the restrictive moral and social code of the main character, Alice Roland, and by contrasting her life with that of her daughter, Asia, explores the possibility of intellectual, sexual and emotional liberation for women. As Rae McGregor wrote:

Mander captures the essence of the New Zealand bush and the speech of New Zealanders. The novel met with good reviews overseas, but some readers in New Zealand perceived in it undertones of immorality, and in the Whāngarei Public Library, for example, the book was put on a discretionary shelf (McGregor, DNZB website, 2007).

Mander was to face persistent criticism in New Zealand for being 'obsessed by sex problems' (Worthington, OCNZL, 1998). While King does not say so, these 'immoral' subjects Mander discusses included venereal disease. However, having 'sex problems' was a common way of dismissing anyone who was 'different' in New Zealand in the early to mid-twentieth century. One feature of the New Zealand of the 1930s was the puritanical attitude to art and literature, and some commentators at the time associated the economic crisis of the Depression with moral laxity. 
In his economic treatise, The Making of New Zealand, while discussing the various arguments around the causes of economic collapse in the late 1920s and early 1930s, G.R. Hawke (1982) states that:

These arguments, like the even vaguer ones that assert that the economy was 'weak' in the 1920s or that unemployment was present in the 1920s so that the unemployment of a different order of magnitude in the 1930s showed that collapse was inevitable, really owe more to morality than to economics. There were many ideas that just as profligacy in an individual has to be repaid by stringency, so the economy as a whole had to put up with social costs as part of the return to a properly puritan standard of behaviour (Hawke, 1982: 138).

The collapse of the world economic system sparked off by the Wall Street crash in New York's Stock Exchange in 1929 caused many variations in the patterns of women's employment statistics and status. Often women's statistics for employment were excluded from the official data. For example, at the height of the Great Depression, King gives the following figures for New Zealand's jobless as being:

around 80,000 in July 1933. Among these were 20,000 general labourers, 5,000 farm workers and 7,000 building tradesmen. These registrations did not include Māori or women or young men under sixteen (King, 2004: 347).

The Depression of the 1930s and its aftermath tended to downgrade the employment situation of women. This was a state of affairs not rectified significantly by the Labour Government as had been hoped and indeed promised at least until the worst effects of the Depression were over, by 1939 with the outbreak of World War Two, and throughout the war until 1945:

Women became active in the economy. The percentage in the public service, for example, rose from five percent to 25 per cent in the war years. Women were appointed to the Legislative Council in 1941 and as Justices of the Peace in 1942. Active women were given new status in this period of manpower shortages at home. But the end of the war heralded a headlong rush into marriage (Aitken, 1975: 27). 
Social historian Sandra Coney (1986) in her history of the Y.W.C.A. quotes Elsie Bennet, General Secretary from 1936 to 1948, who states at the close of World War Two that: 'not enough girls are giving up their jobs to the men they had originally replaced' (Bennet in Coney, 1986: 237). Coney's response is one of incredulity. She writes of Bennet's proclamation:

This was an astonishing about-face from the statements during the war about sexual equality being the price of women's war effort, but it was symptomatic of the times. The men had made their sacrifice, now it was the women's turn to surrender their jobs and independence. Marriage and motherhood were asserting themselves in the public mind as women's highest purpose (Coney, 1986: 237).

Social historian Melanie Nolan (2000) discusses the importance of the government in the employment of women. Throughout the twentieth century the State was instrumental in encouraging women to join the work force, particularly during times of labour shortage, as has been seen during the war. This includes both direct employment by the state under good conditions and changes to policies to vary incentives in the economy generally according to the acuteness of the shortage of labour. Nolan states:

In 1960 the introduction of equal pay in the state sector (a fifth of the female labour force) put them in a privileged position. Thus the state was a major resource for some women, offering them protection and power in training, employment and legislation, as well as in welfare (Nolan, 2000: 36).

\section{Industrialisation in New Zealand 1945-1970}

Between 1926 and 1966 participation by women in the general work force grew by nearly seven percent. In 1926 women totalled 20.3\% of the estimated workforce. By 1966 this had risen to $27.1 \%$. M. Gilson (1969) attributes these figures primarily to the rise of industrialisation. Gilson states:

In New Zealand, as in other economically advanced countries, this meant greater employment opportunities for women in urban centres, while a combination of population growth and rural-urban movement 
has gradually increased the proportion of women who live in towns and cities where paid employment is available to them (Gilson in Forster, 1969: 187).

Here Gilson concurs with Hawke, who expands the real politic of the demographic trends of the period by adding that there was:

a rising proportion of the population being of working age (15-64) from about 1960, and this trend accelerated in the 1970s. To this was added an increased participation rate, that is, more people within the relevant age group wanted a job. A major element in this was the increased tendency of women to seek employment (Hawke, 1982: 333).

In economic and employment terms these changes are echoed by developments in the United States, for example. Claudia Goldin (1990) notes that when economists speak of the 'gender gap' they are referring to systematic differences in the outcomes that men and women achieve in the labour market. She states that in the United States the proportion of women aged twenty-five to forty-four reporting an occupation outside the home increased from $30 \%$ in 1940 to $47 \%$ by 1970 . Advances in participation among women occurred at different times for different demographic groups. In the 1940s it was substantial for women in older age groups, while participation rates for younger (married) women grew significantly in the 1970s and 1980s.

The gender gap that gets the most attention, however, is in earnings. Goldin asks what factors account for the difference in earnings between men and women? The literature shows that obvious observable factors that affect pay, such as education, job experience, and hours of work explain no more than 50 percent of the wage gap. Many observers, says Goldin, have noted that as married women entered the labour force in steadily increasing numbers between 1950 and 1980, their earnings and occupational status relative to men did not improve.

According to Goldin there is another, complementary reason why the gender gap in earnings was stagnating at the same moment that the gender gap in employment was narrowing. As more and more women entered the labour market, many of the new entrants had very little job market experience 
and few skills. However, educational advances, particularly among the college educated, have more recently placed more women on a par with men. Hyman backs up the general ideas on the changing patterns of women's employment, post World War Two, but sees the domestic work within relationships as not having changed. She states:

Technology and social change has led to an increasing range of work being available to women, with domestic work reducing from over onethird of women's jobs to its near disappearance as a live-in occupation during and after the Second World War. Factory, office and professional work of a caring type, at least, became available, although the gender division of labour was as strong as ever (Hyman, 1994: 221).

Earlier Hyman had suggested that increased participation in the labour force along with home labour-saving devices has not decreased women's work at home in their care-giving and nurturing roles. She continues:

Women in the paid workforce, while spending fewer hours in the home than their counterparts for whom this is a full-time job, still have the longest weeks ... [Schor, 1991] ... Hence the double burden indicates that paid work is not necessarily liberating, especially where it is a financial necessity (Hyman, 1994: 220).

In her 1990 publication A Woman's Wage U.S. feminist economist, Alice Kessler-Harris addresses issues that demonstrate the ways in which the changing historical meaning of the wage relation is constructed by society's conceptions of gender. It is too simple to assert that both men's and women's wages are set entirely by supply and demand for different types of labour in the market place. She focuses on three sets of issues that capture the transformation of women's roles: the battle over the minimum wage for women, which exposes the relationship between family ideology and workplace demands; the argument over equal pay for equal work, which challenges gendered patterns of self-esteem and social organization; and the debate over comparable worth, which seeks to incorporate traditionally female values into new work and family trajectories. On the meaning of 'wages' Kessler-Harris states: 
If the wage is, as most economists readily acknowledge, simultaneously a set of ideas about how people can and should live and a marker of social status, then it contains within it a set of social messages and a system of meanings that influence the way women and men behave (Kessler-Harris, 1990: 7).

In other words, while equal wages in the dollar sense may mean the same thing to men and women employees in any given industry, the male/female relationship within that context may still be unequal due to the balance of 'family ideology and workplace demands' alluded to by Hyman.

The question in relation to this thesis is: how did these macro-economic and macro-social events and movements affect individual women living within the society of New Zealand who wanted to become writers and artists? How did social mores and expectations on women, particularly from the end of the Second World War up until the 1970s, impinge on the ambitions and aspirations of women who felt, perhaps, that their own 'artistic vision', in the broadest sense of the concept, was stymied by family obligations and economic dependency. Jock Phillips suggests veterans returning from the war wanted to 'settle down in comfortable domestic life' (Phillips, 1996: 265), and that 'antagonism between the sexes' was a post-WW2 characteristic of New Zealand society. Leslie Hall suggests that married women during this period were often forced to play 'the deferential little-woman role' in unhappy marriages (Hall, 1958: 47-49).

In Chapter $7 \mathrm{I}$ discuss these elements in relation to three specific examples of 'writers/artists' marriages and the dynamics of the male and female partners within them plus one example of a woman writer who was a solo parent at the time when there was no Domestic Purposes Benefit and society frowned upon single women who wanted to keep their children. Butterworth's example is significant because it documents her attempts to become a writer whilst struggling with the restrictions on women. The social and economic circumstances of the post WW2 period, from the evidence above, meant that women's lives were framed and restricted by boundaries that did not generally regard them as equal participants in society.

For the women writers of the period, their economic choices made balancing a life between creative writing and the expected women's role of 
the period very difficult. This was exacerbated by the often misogynist attitudes of the men returning from war service, whose experiences had often damaged and traumatised them to a degree that they rejected women for not having participated in those experiences, and thus being unable to write on topics they considered relevant and important. This is discussed in the following chapter on the literary background. As a poem by 'Alien' called 'Without Malice' puts it:

You, being a modern poet

Must write real he-man stuff

So you will take slabs of prose

And cuts it into chunks like this;

There need be no rhyme nor reason in it ...

No top-notch New Zealand poet any longer

Writes ballads like Jessie Mackay

Or bird-songs like Eileen Duggan

Or lyricisms like Helena Henderson

Or tree-poems like Nellie Macleod ...

And anyway they're only women

(Alien, 2004: 179-180). 


\section{Chapter 4}

\section{Literary Background}

Much writing of history, in the conventional writing of human endeavour, has been just that: 'his story'. There have been significant attempts to redress this situation in the recent past by feminist writers and academics, such as Aorewa McLeod, Adrienne Rich, and Sarah Ell. However, much of the documentation of human life has been from the male perspective. This chapter on the literary background of New Zealand writing discusses these matters in relation to the women writers during the period the present study covers.

Ell writes in the introduction to her second volume of two books on pioneer women in New Zealand:

History books can tell us what happened, and to whom, but only first hand accounts can tell us how it felt, to those directly involved or on the outside looking in. And much of women's history is undocumented few history textbooks record the privations of confinement, or the desolation of the loss of a loved one, or the domestic reality of life on the frontier (Ell, 1993: 9).

As I argue later when discussing Curnow's following of T.S. Eliot's 'ban on the personal', a fundamental difference between men's and women's writing is expressed in this period of New Zealand literature.

\section{Georgians versus Modernists}

In New Zealand between 1945 and 1970 the literary, academic and gender politics were entangled in the controversy between Georgian and Modernist literary styles. Poet James Reeves states in his introduction to the anthology Georgian Poetry:

The word 'Georgian', as applied to a body of poetry written in English during the second and third decades of the twentieth century, came into 
use purely as a descriptive term. By the end of that period it had become a term of critical abuse, and by the beginning of the Second World War it was merely an archaism (Reeves, 1962: xi).

This reflected an international literary debate. For example, the W.G. Bebbington compilation Introducing Modern Poetry: An Anthology, published by Eliot's publishers for whom he worked included just one woman, Edith Sitwell, out of the 21 poets selected. This anthology was first published in 1944, a year before Allen Curnow's collection in 1945 which had only 2 women represented among the 16 poets included. While Bebbington's anthology may not have directly influenced Curnow's inclusion choices, it almost certainly indicates a trend in the poetic politics of the English speaking world of the post-war period.

In 1930 the poetry collection, Kowhai Gold: An Anthology of Contemporary New Zealand Verse, edited by Quentin Pope, a line was drawn between the Georgian poetry identity in New Zealand and the mainly 'manly' Modernist manifestation of verse writing that came to prominence in the 1930s and late 1940s and in some form continued through to the postmodern era of the late 1980s. The Oxford Companion to New Zealand Literature says that Curnow, in his 1945 introduction to his anthology reflecting on Kowhai Gold: 'argues gently that there was little justification for publishing so much that is "trivial if sincere" because the "body of New Zealand verse is not to be enlarged by seeking numbers of additional names"' (Paul Millar in Robinson and Wattie, 1998: 290).

However, it also appears specific to the post-war culture of New Zealand literature that in many respects the New Zealand 'Modernists' also became actively anti-women to some degree. The Modernists equated Georgian poetry with 'femininity', and therefore deemed it flowery and inferior. 1945 was a watershed year in regard to the influence of the so-called new thinking in New Zealand literature. The publication of Curnow's anthology, A Book of New Zealand Verse, in that year continued what was the mid-1930s undermining of the 'Georgian' school of poetry, and therefore the 'female' tradition, in New Zealand poetry which had been strong up to that point. 
This was not always so. In fact, the original English Georgians were very much a male oriented group of writers. In the Penguin Poets series on Georgian poets only one, Victoria Sackville-West, of the nineteen poets represented was a woman. And no-one would consider the likes of Wilfred Owen, Robert Graves, Rupert Brooke or Siegfried Sassoon as writing in a style imbued with 'femininity', or that was in any way 'flowery and inferior'. In his introduction to the Penguin anthology, James Reeves spells out what he thinks defines the movement by stating that Georgianism essentially was the:

celebration of England ... the English countryside, English crafts ... poems about country cottages, old furniture, moss-covered barns, rosescented lanes, apple and cherry orchards ... and the threat to country life which educated readers feared from the growth of urbanism (Reeves, 1962: xv).

While it might appear that the New Zealand Georgians were simply copying the English Georgians a decade or two later it is important to remember that up until the 1940s New Zealand was still very much a rural society and much of the poets' inspiration at the time came from the natural beauty and uniqueness of the New Zealand landscape and bush, to which the name Kowhai Gold attests.

By the 1960s Curnow's position in relation to the Kowhai Gold anthology generation had hardened further. In the introduction to the 1966 edition of The Penguin Book of New Zealand Verse Curnow, as the editor, states that Pope's anthology 'could only corrupt the better, as it encouraged the worse' (Curnow, 1966: 57). He described it as a 'lamentable anthology' ... that 'preserved twenty-three names from the earlier selections of Alexander and Currie, ${ }^{1}$ and added thirty-five new ones, of whom eighteen were women' (Curnow, 1966: 57). Why did Curnow add that seemingly unnecessary adjunct to the last sentence 'of whom eighteen were women'? He seems to imply that too many women poets are being published who have no real talent. Curnow also states that 'Hobbyists and ungifted amateurs crowded Marris's annual New Zealand Best Poems during the thirties' (Curnow, 1966: $56,57)$. If a comparison is made between pre-1945 anthologies of New Zealand poetry several trends relating to gender balance emerge. 
For example, if we look at a number of the Marris New Zealand Best Poems series there are significantly more women poets being published throughout the 1930s and into the 1940s than men. One point of interest here is that despite his later disparaging remarks about Marris's New Zealand Best Poems books, a sonnet by Denis Glover appears in the 1934 edition. But it was 1934 that also saw Glover and fellow editor, lan Milner, present the first openly anti-Georgian anthology, New Poems. In the foreword the editors state their intentions of moving away from poetry that was of the Georgian tradition, which they saw as:

sentimental rhapsodising over love, flowers or sunsets seems to pass as poetry. A predilection for decorative lyricising and emotional embroidery, weakly reminiscent of pre-war Georgian verse, has produced in this country a lifeless growth which, though not necessarily insincere, is in no sense creative (Glover \& Milner, 1934: foreword).

It is not too big a step from this beginning to the later derogatory terminology used by Curnow ten years later. Words like 'decorative', 'embroidery', 'weakly' all act as a catalyst to the masculinist putting down of women writers prevalent in the post-WW2 era. And another telling and prophetic aspect of the New Poems publication is, that of the ten poets represented, only one is a woman, Jean Alison. By contrast, if we look at Marris's yearly anthologies New Zealand Best Poems showing men and women's entry numbers for selected years:

\begin{tabular}{lcc} 
Year & Men & Women \\
\hline 1933 & 8 & 10 \\
1934 & 9 & 9 \\
1936 & 9 & 9 \\
1937 & 7 & 12 \\
1938 & 6 & 11 \\
1941 & $\underline{6}$ & $\underline{8}$ \\
$\underline{\text { Total for period }}$ & $\underline{45}$ & $\underline{59}$
\end{tabular}


Also, compare the above figures with the 1937 volume Verse Alive: number two. This book was also a new venture by those male writers who would go on to dominate much of the literary trends and taste throughout the period which this thesis covers, that is 1945 to 1970 . Of the eleven poets featured in Verse Alive: number two there is only one woman, Robin Hyde. The joint editorship is by $\mathrm{H}$. Winston Rhodes and Denis Glover, who only three years earlier was published in Marris's New Zealand Best Poems. In their foreword the editors of Verse Alive state:

There is some reason for saying that poetry is being killed by kindness, by an artificial and academic respect which raises it beyond the level to which the average man cares to go. He believes that he has no appreciation of poetical imagery or rhythmical speech, and turns to the sporting column which is packed full of wildly grotesque images, or talks to his neighbour in colloquial phrases which often contain the very rhythms that the contemporary poet uses (Rhodes and Glover, 1937: 5).

The editors' comments can be interpreted as setting a blueprint for the philosophy developing which would dominate literary thought in the pre-war period, and on into the post-war period. The fact that this publication has one of the first poems to be aired publicly by the young Allen Curnow is significant as this is the beginning of what would become the male domination of literary 'politically correct' ideals and ideas, based on a poetic framework of the 'average man' who would rather 'turn to the sporting column' than read the poetry of an 'artificial and academic' form of expression. There seems to be no place in this 'radical' Weltanschauung for the woman poet, or indeed the woman who talks to her neighbour over the back fence 'in colloquial phrases' either, and it is in this context that the concept of binarism is relevant.

Binarism is a term that is used to understand and define opposite and often opposing points of view. It is essentially a mode of thought predicated on stable oppositions such as good and evil or male and female and is seen as a specific dichotomy subscribed to or reinforced in such thought. In relation to the present thesis it could be said that a binary mindset was set up by the Modernist male writers to set themselves apart from the Georgian females. As Lawrence Jones states of the Modernist men in his essay on 
'Mulgan, Marris, Schroder' published in A Book in the Hand, they: 'defined themselves by opposition, whether to an idea or a literary movement, such as Georgianism' (Jones, 2000: 143). Thus, if Jones is to be believed, it is the Modernists who set up a binary predisposition in relation to the male-female literary conceits of the period. Therefore, any attempt to address these ideas may also appear as 'binary' by way of explanation.

There were, of course, male poets who were considered Georgian. One example was the poet, publisher and printer, Bob Gormack, who according to Noel Waite writing in Chapter Twelve of $A$ Book in the Hand, felt compelled:

to mount something of a rearguard action in support of the muchmaligned 'Georgian' poets. In the introductory remarks, 'The ballad of Kaka Thompson' was cited as an example of 19th-century balladmaking that provided 'a most satisfactory answer to the many contemporary New Zealand writers - particularly those of the modern Caxton Press school - who still maintain, either directly or by provocative innuendo, that their native land has no poetical and literary traditions worth following or worth investigating' (Waite, 2000: 191).

In this quote from Gormack we find something of interest in the topsy-turvey nature of the Georgian-Modernist debate in New Zealand literature. It would appear ironic that the Modernists who were credited with giving our literature its first true expression of our 'New Zealandness' are seen as believing that 'their native land has no poetical and literary traditions worth following or worth investigating' (Gormack in Waite, 2000: 191). Canterbury academic, Patrick Evans, investigates this conundrum and writes:

The Phoenix generation ... particularly .... Identified with Middleton Murray, who had made the beginnings of his reputation with his savaging of the fourth Georgian anthology [in England] of 1919. By identifying with him the young New Zealand poets [of the 1930s] automatically assumed an opposition to the Georgian strain in New Zealand poetry ... this was to become complicated because it opposed something many of them had within themselves (Evans, 1990: 76-77).

While in his 1981 book, In the Glass Case, poet and critic C.K. Stead quotes Alistair Te Ariki Campbell who said that R.A.K. Mason [that is, a major male poet] 'is undoubtedly a Georgian poet' (Campbell in Stead, 1981: 182) and Stead discusses the fact that there are 'good Georgians and bad Georgians 
... Georgian realists and Georgian sentimentalists' (Stead, 1981: 71). Although he refers to 'the best of the Georgians' (Stead, 1981: 182), he still comes down on the negative side of the Georgian-Modernist debate, as do the majority of the critics of the era, from Curnow to Baxter to Glover. This would not appear so bad if it were just a matter of literary taste, for example. However, the fact that 'Georgianism' became a derogatory term analogous with 'female' in the literary/poetry world of the 1930s and into the following decades denotes an underlying trend towards anti-female behaviour of male writers, publishers and critics in the period this study covers.

\section{No place for a woman}

English language convention often uses the words 'man' and 'men' to denote all people, men and women. At least in the grammatical convention of 'man' meaning a 'person' it is assumed that the term implies women also. However, in the extreme 'masculinist' tradition developing in the literary world of New Zealand in this period women almost ceased to exist, linguistically at least. It is interesting to note here that this phenomenon reaches far beyond just the New Zealand situation. For example, American poet Louise Bernikow notes that the "heightened states of emotion out of which male poets were creating poetry were praised as revolutionary: the heightened states of female emotion were denigrated and dismissed as second-rate' (Bernikow, 1974: 6).

Although Bernikow is considering $19^{\text {th }}$ Century English poetry the underlying truth is the same in the middle $20^{\text {th }}$ Century New Zealand literary scene with regard to women and men writers. Even Robin Hyde, who appears in both of Curnow's anthologies, Caxton and Penguin, and is the only woman poet in Verse Alive: number two, does not escape the scathing male put-downs. For example, Curnow's remarks about her as a poet. Having more or less pitied her for her emotional instability he then states how Hyde 'fought to free her vision from its literary swathings - and in verse her worst enemy was the passionate crush on poetry with which she began. Her writing was near hysteria, more often than not, and she was incurably exhibitionistic' (Curnow, 1966: 57). Here Curnow exhibits the attitudes I have 
identified. He constructs for New Zealand readers a view of a stereotypical 'female poet' alluded to by Bernikow.

American feminist critic Joanna Russ (1984) considers the problems inherent in the negative attitudes towards writing by women and why it is often not taken seriously by the literary establishment. The cover has a series of statements that typify some of the sexist thinking on writing by women authors, whether they are novelists, poets, or non-fiction writers. The parts quoted in capital letters are in red on the original cover:

SHE DIDN'T WRITE IT. But it's clear she did the deed ... SHE WROTE IT, BUT SHE SHOULDN'T HAVE. It's political, sexual, masculine, feminist ... SHE WROTE IT, BUT LOOK WHAT SHE WROTE ABOUT. The bedroom, the kitchen, her family. Other women! ... SHE WROTE IT, BUT SHE ONLY WROTE ONE OF IT. 'Jane Eyre. Poor dear, that's all she ever' ... SHE WROTE IT, BUT SHE ISN'T REALLY AN ARTIST, AND IT ISN'T REALLY ART. It's a thriller, a romance, a children's book. It's sci fi! ... SHE WROTE IT, BUT SHE HAD HELP. Robert Browning. Branwell Bronté. Her own 'masculine side' ... SHE WROTE IT, BUT SHE'S AN ANOMALY. Woolf. With Leonard's help ... SHE WROTE IT, BUT ...' (Russ, 1984).

The implications of this for the women writers in New Zealand are clear, particularly during the post-war period up to the 1970s. Russ, in a chapter titled 'Anomalousness', quotes Dolores Palomo on how the 'refined eyes of scholarship condemn 'one half to two thirds of the fiction penned in the eighteenth century' as minor, mediocre, or salacious - that is, the fiction written by women' (Russ, 1984: 84). With what we know of the women writers in New Zealand, beginning in the 1930s, this demonstrates how these women writers seemed to take on a lower status, not only as writers but also as human beings.

Russ quotes American poet Erica Jong describing her literary education:

being a woman means, unfortunately, believing a lot of male definitions ... I learned what an orgasm was from D.H. Lawrence, disguised as Lady Chatterley ... (For years I measured my orgasms against Lady Chatterley's and wondered what was wrong with me ...) I learned from Dostoevski that they (women) have no religious feeling. I learned from 
Swift and Pope that they have too much religious feeling (and therefore can never be quite rational). I learned from Faulkner that they are earthmothers and at one with the moon and the tide and the crops. I learned from Freud that they have deficient superegos and are forever 'incomplete' (Jong in Russ, 1984: 89).

Jong continues, stating a view that is particularly pertinent concerning the attitude of the New Zealand male writers to women writers of the period. She explains that poetry for her was masculine. A visiting male writer to her university:

went on and on about how women couldn't possibly be authors. Their experience was too limited ... They didn't know blood and guts and fucking whores and puking in the streets ... this [she said] made me miserable (Jong: in Russ, 1984: 89-90).

The latter certainly reflects what some of the male writers in New Zealand thought and felt about women writers and their literary endeavours. However, upon consideration, it shows up the men. For example, the fact that women menstruate and some experience childbirth which can often be painful may be said to negate the argument that women do not experience blood and physical extremes. It could be said that until you experience giving birth you don't know about 'blood and guts'.

The underlying sense of violence as 'male expression' as reported by Jong, as being the only legitimate poetic form, also comes into play in the literary world of New Zealand. After describing a particularly nasty scene of rape performed by a New Zealand soldier in a novel set during WW2, as an act of revenge on a nurse who dared to criticise a failed military action, Kai Jensen in Whole Men continues by writing that war literature was an extreme manifestation of the misogynist way that women were often depicted in our poetry and fiction.

In a 1968 essay on the state of New Zealand poetry, Curnow's conclusion summed up his views with a quotation from his poem:

Love-poems if you like. But keep them short.

It's all vieux jeu, unless you're crude and stark.

She won't, we needn't, read them. Sport, 
Tell her you love her, and tell her in the dark

(Curnow, 1987: 229).

\section{The audience is male}

The poet is imagined here as male, as is the audience of Curnow's paper, while the beloved is presumed to be uninterested in poetry. Jensen (1996) discusses Fairburn's misogynist masterpiece, The Woman Problem. In this long essay, which Jensen describes as being 'semi-serious', the poet A.R.D. Fairburn argues for male domination of women in marriage, on the grounds that equality between men and women was a 'sentimental' and 'romantic' heresy, spread by feminists and homosexuals. Women were happier in marriage where husbands kept a firm hand on the reins. This was better for society as well, since Fairburn claimed that women were inherently immoral and anti-social because of their natural focus on children and family:

most women have little notion of abstract justice ... they are incapable of attaching importance to principles of any kind ... women's minds are not designed for the purpose of making judgements on matters that call for objective consideration. [Women who had] acquired certain masculine habits of mind, through their association with intelligent men [might be] most charming [but were] usually marginal creatures in the book of Genesis (Fairburn, 1967, 18-19).

Imagine how much deeper would have been Jong's despair had she been a New Zealand woman writer reading these words in 1967, when The Woman Problem was first published. Fairburn discusses the development of civilization as the work of men, whereas the work of women he sees as coming from natural instincts, therefore something for men to tame. He states that civilization implies the repression of natural desires and that:

The higher refinements of civilization are the work of man, not of woman. His strongest motive has been, at all times, the finding of creative satisfaction. Woman receives this satisfaction as her birthright. Man, being all but irrelevant to the business of procreation, has had to invent other means of satisfying his creative instinct (Fairburn, 1967: 34). 
Fairburn then goes on to quote the French novelist Baudelaire who said: 'Woman is natural, therefore abominable'. He may have meant that woman is completely tied up with the biological process, and has no real sympathy for the world of art-for-art's-sake which had, in his time, begun to detach itself consciously from the full context of life - just as the homosexual is detached from society.

But we may suspect that Baudelaire, being a man of subtle mind, meant a good deal more than that. He was, perhaps, not merely justifying the unreal world of 'pure aesthetics' and 'pure sex', but asserting also, for those with ears keen enough to hear, that woman presents a constant threat to civilized life (Fairburn, 1967: 35).

While Fairburn may be expressing extreme views to get across a less extreme or even satirical point, it appeared that these views were common currency among male intellectuals during the 1940s, 1950s and 1960s, in New Zealand and elsewhere in the Western World. This helps to build a picture of the underlying misogynist nature of their attitude to women writers.

The implication that women are somehow indifferent to the finer feelings, as expressed in Curnow's quote from Glover's poem, for example, means that women have no ideas beyond their natural instincts. Like nature itself, this indifference extends into their personal relationships. The poet, James $\mathrm{K}$. Baxter, in an unpublished letter to fellow poet, Victor O'Leary, states: 'Women are cruel. I think you are sometimes too nice to them - but perhaps you try harder than I have done' (Baxter, unpublished poem: c1950s). ${ }^{2}$

\section{Ban on the personal}

However, if we turn from the question of women being 'natural' and men being somehow supernatural or even supra-natural, and look at the reality of the women's lives, which often consisted of decades of domestic drudgery, then we can appreciate why women were not at the forefront of the intellectual or cultural aspects of society. Carolyn Heilbrun considers these issues and shows through the lives of individual writers how erroneous some 
male assumptions were in relation to their ideas of the male/female utopias. She quotes Rich's discussion of the human condition. Rich notes: 'those who speak largely of the human condition are usually those most exempt from its oppressions - whether of sex, race, or servitude' (Rich in Heilbrun, 1988: 68).

Heilbrun goes on to discuss autobiography in women's writing, stating that while it had become common for both women and men, that it was chiefly in Rich's generation of women poets - Plath, Sexton, Kumin, Kizer, Cooper, Levertov - that T.S. Eliot's ban upon the personal was defied' (Heilbrun, 1988: 69). It is here that the women poets of New Zealand from the 1940s to the 1970s were also denigrated, for Curnow in particular was an advocate for the Eliot version of Modernist poetic expression, in which the 'personal' was not acceptable.

The battle that women had between their social, or as Fairburn believed, their 'natural' position in the world, whereby they have no need for creative or artistic expression, comes under scrutiny when Heilburn discusses the writing of, among others, American poet, Anne Sexton. Sexton had explained to an interviewer:

Until I was twenty-eight I had a kind of buried self who didn't know she could do anything but make white sauce and diaper babies ... I was trying my damndest to lead a conventional life, for that was how I was brought up, and it was what my husband wanted of me. But one can't build little white picket fences to keep nightmares out ... (Sexton in Heilbrun, 1988: 70).

The importance of this passage, Heilbrun argues, lies in its truth that women could not previously express. She explains:

there are two other points that Diane Middlebrook has clearly identified for us: that 'Sexton experienced the home as a sphere of confinement and stultification,' and that she escaped through the way of death. For Sexton and Plath, suicide became part of life, so violent was the action necessary for rebirth and truth (Heilbrun, 1988: 70).

Heilbrun quotes Carolyn Kizer's words which seem to sum up the plight of women poets down through the ages: 
From Sappho to myself, consider the fate of women How unwomanly to discuss it!

(Kizer in Heilbrun, 1988: 70.)

These issues of women's creativity can be seen in the work of New Zealand novelist and poet Robin Hyde, who like Plath, Sexton and Woolf, committed suicide in what could be regarded as an act of creative destruction. In his introduction to The Penguin Book of New Zealand Verse Curnow, again shows his own predilection towards Eliot's 'ban upon the personal' poetical philosophy. He respects Hyde enough as a poet to include her in this anthology, though as in his earlier Caxton anthology, he remains critical of her use of personal motifs. While he states that in the last five years of her life she produced her best work he goes on to comment that:

By incessant writing, incessant change, she fought to free her vision from its literary swathings - and in verse her worst enemy was the passionate crush on poetry with which she began. Her writing was near hysteria, more often than not, and she was incurably exhibitionistic: any moment we are likely to get the awful archness of her lines on 'Katherine Mansfield': (Curnow, 1966: 57).

He was referring to Hyde's sympathetic lines on Mansfield:

Our little Darkness, in the shadow sleeping,

Among the strangers you could better trust

Right was your faring, Wings: ...

(Hyde in Curnow, 1966: 57).

\section{Giving New Zealand women 'a swelled head'}

Curnow says of Hyde that New Zealand had concentrated all its forces to confound one who had neither the will nor the opportunity to escape early, like Katherine Mansfield. Curnow quotes from an unpublished letter by eccentric New Zealand poet and pretender to the Polish throne, Count Geoffrey Potocki de Montalk, to the poet A.R.D. Fairburn, stating his view that: 'K.M. has had one most deplorable result - that of giving N.Z. women a swelled head' (de Montalk in Curnow, 1966: 57). 
This is interesting as in his memoir de Montalk writes of poet V. Alison Grant, one of the Kowhai Gold poets, as being:

One of the most remarkable of the authors and artists of New Zealand in my generation ... She is an unusually gifted person, but when young was fantastically ill-mannered in the best New Zealand fashion ... She used to be a serious reminder of why one had left New Zealand. And also of the fact that choice New Zealanders are much more gifted than their opposite numbers in England (de Montalk, 1983: 30-31).

Here, it seems he may 'give women a swelled head'. De Montalk touches on the New Zealander abroad in his comments on Grant, something I explore further in the chapter on women novelists.

Curnow's approach towards poetry, his belief that it should not be personal but somehow objective, puts him squarely on the masculinist side of the division, with his ideas reflecting an essentialist idea of maleness as superior in poetic expression. Hyman discusses this type of dichotomy, stating:

Orthodox economics is based on the positivist approach of the natural sciences. Feminist critiques of science see this approach as imbued with erroneous notions of value neutrality, objectivity and dualistic thinking. Dualisms such as mind/body, abstract/concrete, objective/ subjective, rational/emotional and, by inference at least, male/female, with the first involving a superior level of thinking, are criticised as limited, hierarchical and gender based. The separation of knower from known, with detachment a major virtue, means that scientific measurement alone can contribute to knowledge, with no supplementation from experience or from sensual, spiritual or emotional knowledge (Hyman, 1994: 35).

While Hyman is discussing economics and its social value, this can be applied to suggest there are similar biases in male poets' thinking during the post-war period on poetry and intellectual life generally in relation to their art, with their ban upon the personal and their attitudes towards women, and women writers in particular. It is with this background of thought in mind that the period 1945 to 1970 became a cultural 'wasteland' for the women writers of the period. 
Alan Brunton sums up the situation regarding the place of women in the poetic scheme of things with reference to the male poets. In Years Ago Today he writes:

The 'poet', as defined by increasingly surly anthologies, wavered between victim and victor but was in any case authoritarian, and patriarchal. The hero was a man under an existential curse, whose fate was to be outnumbered and caught in a hopeless situation and destroyed: he was the female's necessary sacrifice. The vision was monarchical, solar and defensive. The female was regarded as either dully domestic or sexually hysterical, or both. The ethical basis of this myth was where it was most convoluted. Sacrifice of the self is necessary but sacrifice increases pollution. This should not cause pessimism for only in pollution can redemption be sought. The cruel twist is that pollution is the absence of god. Curnow's god was absent and therefore he despaired (Brunton, 1997: 36).

This male adherence to the 'non-feeling', non-personal usurping of the literary world, when academic objectivity has been made 'the law' of literary taste, appears to have begun in the 1930s and followed through from the post-war period to the 1970s. Else writes that those:

working beyond such circles, including most women writers, became increasingly marginalized from the body of work emerging as New Zealand literature. The records of the women writers' organisations suggest that from the 1940s to the late 1960s, the majority of members thought of 'New Zealand literature' as something being written elsewhere, principally by men - some of whom they invited to lecture to them - rather than something they themselves could take part in producing (Else, 1993: 451).

However, this too began to change. In relation to the male 'establishment' of writers and publishers I have written elsewhere:

But, however much the 'radicals' of the '30s still saw themselves in that vein, they had become by the end of the 1960s the literary 'establishment' of New Zealand. The fact that, except for Janet Paul, the main publishers of the time were male, Pākehā, and becoming increasingly conservative in relation to the ' 60 s generation now growing up around them, meant they were beginning to lose their relevance (O'Leary, 2007: 19). 
In her editorial to the 'women's' issue of Landfall Linda Hardy discussed the then current prestige and popularity of 'women's writing', and asked the question:

What need is there, then, for Landfall to put out a 'special issue' devoted to 'women's writing'? A rough count in five recent issues of this magazine gives me a total of 29 women contributing stories and poems, as against 39 men; far from equality, but not 'silence' either (Hardy, 1985: 400).

A similar analysis of an earlier five issues of Landfall 1951 to 1952 reveals that there were 10 women alongside 34 men, with one of the women, Ruth France, using the male pseudonym, Paul Henderson. Another analysis of a further five issues from late 1952 to 1954 reveals an even more dramatic picture when there were 36 men writers as against 2 women writers. In 1955 and 1956 there were 28 men and 6 women. And during the so-called liberal 1960s, the years 1968 to 1969, the gap increased rather than decreased, with 49 men published in five issues, and only 9 women.

These figures illustrate a central feature of this thesis, that is, the exclusion or limiting of women writers during the period 1945-70. However, two recent issues of Landfall in 1999 show a change. In those issues the total of 28 men and 19 women indicates a seismic shift. This, like the demand for equal pay, suggests that there has been some movement towards equality from the period of the late 1940s to more recent times in relation to a more equitable distribution of capital, both financial and intellectual, between men and women.

This is seen in the workings of the New Zealand Women Writers' Society, a group of women based in Wellington, which began in 1932 and finished in 1991. For example, the Wellington poet, novelist and journalist, Pat Lawlor, is eulogised in the 1982 history of the society:

Mr Lawlor chaired the first meeting of the Society convened by Nellie Donovan and until his death at the age of 86 in 1979, he kept up his interest and encouragement and was affectionately known as 'the father of the Society'. On the Society's $25^{\text {th }}$ Birthday he presented a collection of Katherine Mansfield books and manuscripts (France et al, 1982: 5). 
This was a prize for a competition for writing about Wellington. Lawlor was in 1977 the only male and was elected Hon. Vice-President of the Society. Another example of the Women Writers of New Zealand Society seeking male approval can be seen in the 1953 publication POEMS: Anthology of New Zealand Women Writers. In some respects, it may be seen as an answer to the arrogance and negativity displayed in Curnow's attitude to women poets via his rejection of Georgianism and their lack of representation in his 1945 A Book of New Zealand Verse.

However, the editorial for POEMS: Anthology of New Zealand Women Writers was written by a man, Alan R. Dunlop. The opposite situation to Lawlor and Dunlop's 'patronage' can be seen in women like Elizabeth Pudsey Dawson, better known as Peter Dawson in New Zealand literary circles, who was a loyal and generous friend to both Sargeson and Frame. Described as 'left-wing and lesbian' (King, 2000) Dawson's assistance to many other writers, the majority of whom were men, over a forty-year period in New Zealand from the late 1940s until she died in 1986, could be seen as an attempt to buy acceptance in the literary scene. The fact that many who benefited from her generosity never acknowledged her support (Laurie 2003) makes it surprising that she did not do more to assist women writers of the period other than Frame.

This chapter has discussed some background for the intellectual and literary climate existing in New Zealand during the post-war years and some of the anti-female attitudes women writers had to endure. The next chapter considers some individual women poets and more personal literary controversies involving the male/female politics of the time.

\footnotetext{
${ }^{1}$ Editors of the 1926 anthology A Treasury of New Zealand Verse.

${ }^{2}$ From a copy of a letter given to me by Victor O'Leary, who was a member of the Glenco group of Wellington Poets in the 1950s, which also included Baxter. The letter is headed 'School Publications, Dept. of Education, Wellington, $9^{\text {th }}$ August 1962'. Baxter's letter was accompanied by a poem dedicated to 'Vic O'Leary' - the title of the poem is 'Mazeppa'.
} 


\section{Chapter 5}

\section{Women Poets}

This chapter centres on the poets of the period covered by this study. In the context of the status of women's poetry written and published during the time of the post-war period up to the 1970s there is evidence to suggest that male publishers and male poets in particular were quite disparaging towards women poets. I argue that many negative attitudes towards women poets came from a particular aspect of male writing, from those writers trying to build a New Zealand literature based on a philosophy of the 'man alone' ethos, informed by male war experience.

This would later be epitomized by the National Party's Prime Minister of the 1970s and 1980s, Robert Muldoon, as the 'ordinary bloke', although I doubt that poets such as Allen Curnow, James K. Baxter or Denis Glover would appreciate this association. Mark Williams (2008) points out that Blanche Baughan and Ursula Bethell, as with many other women writers of the period, have been caught up in the ongoing disputes about the Modernist philosophy of the 1930s and its effects on earlier generations of writers. A.R.D. Fairburn, R.A.K. Mason and Glover were all central movers of that movement, as was Curnow.

In 2009 I attended the funeral of Alistair Te Ariki Campbell at Pukerua Bay north of Wellington where he had lived with his second wife, poet Meg Campbell, for many years. At the funeral a poem by Campbell's first wife Fleur Adcock, now a major British poet, was read by her sister, novelist and poet Marilyn Duckworth. This poem made a telling point:

of his romantic looks

and silly girls like me, foolish enough to marry

what I wanted to be

(Adcock, 2009: 13).

This elicited some laughter from those who knew the two, and it was a witty comment on their relationship. However, Adcock had previously written: '... I write when and wherever I can (not always easy); and my commitment to 
poetry is total' (Adcock in Ensing, 1977: 15), which I thought a good example of how women writers struggled to become recognised as poets in their own right during this period.

\section{Ruth Gilbert}

The poet Ruth Gilbert provides another example of the experience of women poets during the period this study covers, her first publication appearing in 1941. Gilbert offers a case study for these women poets, as she is at the heart of the controversy regarding the antagonism that some men writers and publishers displayed towards the work of their women counterparts up to the feminist revival of the 1970s.

Evidence of this antipathy can be found in 1957 when the literary magazine numbers 7 published a letter by Willow Macky in which she criticises the critics of the New Zealand literary scene, in particular the editor of the numbers series, poet Louis Johnson, for his unfavourable review of the latest book by Gilbert, The Sunlit Hour. Macky doesn't end there. Her letter becomes both a plea to her male colleagues and an indictment against them when it comes to their treatment of their female counterparts. She states:

Most women, if they wish for success, will try to conform, monkey-like, to the masculine pattern; others, by remaining true to their feminine insight, risk opposition and failure in male-dominated fields (Macky in numbers $7,1957: 26)$.

The question is: why was this the case? This letter is evidence that women actually felt like this and expressed these frustrations about the way they were treated by male editors and I discuss this later. I have appended the full text of Macky's letter and the editor's reply.

The 1970 cut-off point for this thesis roughly coincides with the emergence of the so-called 'second wave' feminist movement in New Zealand. However, when lesbian-feminist poet Heather McPherson was asked about her early attempts to get into print before and around 1970 she said she had poems published in Landfall and had approached Leo Bensemann, then Caxton Press and Landfall editor, with a collection of 
poems, mentioning to him that she had become a feminist. His reply was that Rita Cook (Rita Angus) had become a feminist 'but it didn't do her any good either' (McPherson, 2007: 116).

These examples illustrate some of the difficulties and antipathies existing between the men and women literary figures during the period of my study. They illustrate some of the restraints and difficulties women writers worked under. Gilbert's experience reflects the hurt and feeling of unfair treatment given to women writers by their male counterparts, editors and publishers during this period. As early as 1943 her poem 'Shooting Season', unpublished until the 1988 collection Early Poems: 1938-1944, describes male writers taking pot-shots at female writers, just two years after her first appearance in print.
When man goes forth
At rise of sun
With haversack
And well-greased gun
How most unpleasant
To be a pheasant;
And what abysmal luck
To find oneself a duck
(Gilbert, 1988: 38).

Nielsen Wright's book on her quotes Gilbert stating that 'Shooting Season' was written in 1943. However, when Wright interviewed Gilbert in 1988 she associated 'Shooting Season' with James K. Baxter and Louis Johnson as the shooters. Wright found this impossible since the poem was dated 1943. He continues that he knew Gilbert felt she was under attack from Baxter and Johnson in the 1950's and 1960's, as had Eileen Duggan at PEN committee meetings (Wright, 2007).

A brief outline profile of Gilbert's life and publishing history illustrates her place in both literary and social settings during the period. Born in 1917 at Greytown, Wairarapa, as an adult she could be regarded as typical of many New Zealand women during and after WW2, as she married and had children. During her long literary career Gilbert's poems have appeared in newspapers, books and magazines. 
Her poems were published in C.A. Marris's New Zealand's Best Poems, Art in New Zealand, The Evening Post, Lyric Poems of New Zealand, Johnson's New Zealand Poetry Yearbook, and Frank McKay's Poetry New Zealand. She has also been published in Australia, Canada, England, Ireland, and her work has been broadcast on the BBC and the former NZBC (now Radio New Zealand). Her publishing and writing career [see appendix 6] provides perspective on the literary trends and views of other authors in relation to the gender politics of the period.

Gilbert's post-war poems to 1950 show how her career as a published poet began, also how it was undermined by what I argue were the misogynist views prevalent among publishers and anthologists of the time. Brasch included Gilbert in the literary magazine Landfall only once: ${ }^{1}$ Landfall 11, March 1948. 'Lazarus' sequence: 1 Betrothed to Lazarus; 2 The Sisters of Lazarus; 3 Lazarus speaks, which were subsequently published by Reed in 1949 under the title Lazarus and Other Poems. The author note for the Landfall issue states that her work had also appeared in Art in New Zealand, The Evening Post and New Zealand Best Poems.

For Gilbert, 1948 was a very successful year. Her work 'Overheard in a garden: Anthem poems' was published in Yearbook of the Arts in New Zealand (Gilbert, 1948: 154-155). She was also published by Quill, the magazine of the Society of New Zealand Women Writers and Artists. A note in Quill about 'Lazarus' states the poem won the Society's 'Donovan Cup Competition' for unpublished work in October 1947. It also won the Jessie Mackay Memorial prize for verse in June 1948. This prize had been established the year of Jessie Mackay's death in 1938 by the New Zealand centre of the writers' organisation PEN. Mackay's work was included in a number of anthologies of New Zealand poetry which were produced in her lifetime, and in the anthology edited by Robert Chapman and Jonathan Bennett in 1956. But the DNZB entry on her states:

However, her exclusion from the 1960 Penguin book of New Zealand verse, edited by Allen Curnow, limited awareness of her contribution to New Zealand literature among later generations of readers. Mackay's place in the history of New Zealand poetry has been considerably under-recognised. (Roberts, DNZB: website). 
The Spring 1948 issue of the American literary magazine Voices No 133 also features Gilbert's work. In the selection of New Zealand poetry Gilbert leads, filling nearly two pages. The Yearbook of the Arts in New Zealand 1949, (5: 134) has Gilbert's poem 'Phobia', and her first full collection Lazarus and Other Poems was published by A.H. \& A.W. Reed, Wellington, in 1949. Also in 1949 the New Zealand Listener ${ }^{2}$ recorded that Gilbert won the 'Jessie Mackay Memorial prize' for poetry. She had in fact won the prize twice in successive years, 1948 and 1949, and would again in 1967, when she shared that year's prize with Baxter. In 1949 Gilbert began to contribute poems to the New Zealand Listener and did so up until March 1975; that is, she contributed during the years when Monte Holcroft was editor.

Gilbert states that when her book was published in London she had reviews not influenced by New Zealand literary politics, hence different from what she would have received in New Zealand. Gilbert said that she thought being a New Zealand woman writer of her period was a more difficult life than her male counterparts:

Here you might be either over-praised or over-damned ... I think most male reviewers approach a piece of writing differently when they see a woman's name on it. They unconsciously patronise. A writer wants to be recognised as a writer, not as a man or a woman. But even when a woman writer becomes known, she is not the male writer's equal (Gilbert in Wright, 2007: 17-18).

Gilbert stated that she had three books of verse published by that time and her work had appeared in anthologies of New Zealand and Commonwealth verse and in periodicals in New Zealand, Australia, Canada and Ireland; her work had also been broadcast by the B.B.C. Gilbert explained:

I am not prolific enough to be sending it out all over the place ... I don't sit down at a desk to write. With me it's a matter of waiting till I have something to say. Then anything may catch my eye and I'm away (Gilbert in Wright, 2007: 18).

With this outlook it's hardly surprising that Gilbert always liked the musical, lyrical and perhaps more traditional verse. She continued that this was her voice, not that she was against the moderns. Gilbert, who wrote verse from 
the age of about nine, kept black books with 'the most ghastly verse' and contributed to her school magazine (Gilbert, 2007). She was in her early 20s when a friend suggested she should show her verse to C.A. Marris. Marris, then writing in The Evening Post as Percy Flage, told her: 'You can write, but you mustn't send anything out till I tell you' (Marris in Wright, 2007: 18-19). He got her work first into the Post, under the initial 'R', and later into Art in New Zealand and New Zealand Best Poems.

\section{New Zealand Women Writers' Society}

'Mr. Marris has been much criticised,' Gilbert says. 'But I feel he was genuinely interested in New Zealand literature and was only trying to get writers published'. ${ }^{3}$ While Gilbert has always faced the hostility of some male writers, especially between 1943 and 1966, she was always highly respected among other women writers. In 1953 Gilbert appeared in POEMS: Anthology by New Zealand Women Writers, which was the first 'women only' poetry anthology to appear in New Zealand. Such an anthology was first proposed at the July 1942 AGM of the New Zealand Women Writers' Society [New Zealand WWS] 'a suggestion that the society publish a book for public sale was rejected as not opportune under the war conditions of the time' (France et al, 1982: 55). The editor of the 1953 book, Alan R. Dunlop, stated in his introduction, "it introduces to New Zealanders a body of poetry by writers so far largely unknown, and it marks one of the rare occasions in any country when women writers have published a volume devoted exclusively to their own poetry'. (Dunlop, 1953: 5)

Many male commentators were disparaging of the New Zealand WWS. Michael King, for example, in his biography of Janet Frame described them as a 'guild of largely (but not wholly) undistinguished authors and would-be authors'. (King, 2000: 381) However, Frame herself saw a different side of the Society and wrote in an introduction to a history of the New Zealand Women Writers' Society, '... I think the history is important. It is also important for me because my mother was one of the early writers - mostly 
women at home with a family - who gained such solace from the writers' society founded during the Depression. I think I have an early edition of the Journal of the New Zealand Women's Writers' and Artists Society ...' (Frame in Hayward \& Cowley, 1982: 1). ${ }^{4}$

As previously stated Curnow's 1951 revised edition of his groundbreaking anthology $A$ Book of New Zealand Verse had 20 entries by men and 3 by women. It is interesting to conjecture that the women's anthology of the following year could be seen as a direct challenge to Curnow's anti-Georgian and anti-women writing, for he saw the two, Georgianism and femaleness, I argue, as being the same thing. A later anthology can also be compared with Curnow's to contrast the different male to female ratio of representation in literary collections. Robert Chapman \& Jonathan Bennet's 1956 An Anthology of New Zealand Verse had 34 entries by men and 9 by women, one of whom was Gilbert - still a huge difference and an even greater one in absolute terms though somewhat more balanced in proportional terms.

It is interesting to note and contrast two books of poetry published in the year 1936 that seem to set the tone for the times to come in the post-war period through to the 1970s. New Zealand Best Poems 1936 edited by C.A. Marris had poems by 9 women and 10 men, while Verse Alive number two, selected by H. Winston Rhodes and Denis Glover, had one woman and 10 men, and Robin Hyde is the only woman to appear in both. Nelson Wattie's article in The Oxford Companion to New Zealand Literature speaks of the contribution made to the furthering of New Zealand letters by the Christchurch and Auckland newspaper, The Sun, which existed from 1914 until 1934. This is important as it is at this juncture around 1935 that it appears the rift begins with the traditional, Georgian and therefore women poets. I argue that the newer, mostly male poets, saw themselves as progressive, bohemian, Modernist-masculinist poets, as opposed to the Georgian/female poets. Wattie quotes Pat Lawlor, who wrote in 1935 about The Sun: 
the pivot of its enterprise, its literary staff, was unequalled in the history of journalism in this country ... the poets, short-story writers and essayists The Sun has discovered and helped over the last two decades represent nearly every New Zealand writer who has achieved any distinction in his profession during that period (Lawlor in 'Oxford Companion', 1998: 520). ${ }^{5}$

Robin Hyde referred to The Sun as 'the one and only daily to pay any serious attention to literary work taken from the stores of New Zealand writers' (Hyde in 'Oxford Companion', 1998: 520). The literary editors of The Sun, firstly Marris and then J.H.E Schroder, appear to have given equal time and space to both male and female writers.

A look at the list of writers to appear in the paper's Christmas editions each year sees the names of prominent writers of each sex. Hector Bolitho, Eileen Duggan, C.R. Allen, Robin Hyde, Monte Holcroft, Jane Mander and Will Lawson are all there. In an ironic twist Wattie points out that A.R.D Fairburn's poem for 1928: 'Kowhai', 'is as sentimentally Georgian as any of the poems he and his [masculinist] comrades were later to scorn' (Wattie, 1998: 520). The Sun was the first daily to serialise the work of New Zealand novelists, for example, Edith Howe's Young Pioneers in 1923-1924, and it also has the distinction of having published the internationally renowned New Zealand author, Ngaio Marsh, including her first ever published story, 'The Night Train from Grey' in 1919.

Many of the best-known New Zealand writers until the 1930s were women, for example, Katherine Mansfield, Jane Mander, Jean Devanny, Blanche Baughan, Eileen Duggan, Ursula Bethell. But the winds of change were afoot. In Whole Men Kai Jensen states: 'The group of young male writers that arose in the 1930s characterised this kind of writing [Georgian] as effeminate and claimed to offer a more down-to-earth, masculine alternative' (Jensen, 1996: 43). Jensen adds that Sargeson identified Mansfield's use of metaphorical language with the 'feminine tradition' of fiction, and Glover recalled that it was 'time to impart new vitality to New Zealand verse. No more leisurely-whimsy, feminine-mimsy stuff' (Glover, 1981: 94). In 1937 Glover complained: 'Alas, New Zealand literature distils/an atmosphere of petticoats and frills' (Glover, 1981: 6) and Fairburn had grumbled to Glover in 
a letter in 1935 that 'the Menstrual School of Poetry is in the ascendant, and a mere male is treated with scant respect' (Fairburn, 1981: 95).

Jensen points out that Curnow thought at this time that low standards of literary editing had allowed '[hobbyists] and ungifted amateurs' (Curnow in Jensen, 1996: 43) to be published, and in support noted that, of thirty-five new poets published in Kowhai Gold (1930), eighteen were women, which he apparently regarded as a terrible indictment. $\mathrm{H}$. Winston Rhodes, who in 1938 in the literary paper Tomorrow wrote: 'The beginnings of a national literature are to be found when writers turn to deal with the normal activities of ordinary men' (Rhodes in Barrowman, 1991: 59). Perhaps there are no 'ordinary women'. Ironically, Quentin Pope, editor of Kowhai Gold, expressed the hope that its contents might serve as the foundation of a New Zealand literature, but within a few years the anthology was being seen as the embodiment of a moribund tradition of versifying, dominated by 'genteel female poets'.

\section{Eileen Duggan}

Peter Whiteford (2008) notes that prominent among the poets included in Kowhai Gold was Eileen Duggan, whose father, like Janet Frame's, was a railway worker and as such one of Rhodes' 'ordinary men'. Whiteford explains that Duggan:

until then [the publication of Kowhai Gold] had enjoyed a reputation second to none. Internationally, her poetry continued to be well received, but in New Zealand her standing began to wane, and never recovered; a largely male, secular group of younger poets and critics, attracted by Modernist forms and philosophies, had little time for her more traditional lyrics, or for her active Catholicism. Her subsequent absence from major anthologies was as a result of her own decision, but it was a decision she felt forced to make by the prejudice and animosity she encountered (Whiteford, 2008: website, no pagination).

On the dust-jacket of Duggan's 1951 collection, More Poems, is a quote from a review of her work in the Manchester Guardian stating 'Our English [i.e. literature] anthologists will not have done their duty until they have brought in 
Miss Duggan's best'. It is conceivable that such statements from an overseas publication of high literary standing may have made Curnow increase his efforts to convince Duggan to allow her work in his anthology.

Poet Walter de la Mare's introduction to Duggan's 1937 book Poems drew attention to the freshness, incisiveness, and energy of the writing, and the presence of 'a unique feeling expressed in a renewed language' (de la Mare, 1937: 5), but even as her work was published, changes in literary fashion were reaching New Zealand that would ultimately see her and many other women writers marginalized within the New Zealand literary community. I have noted earlier that Glover, in The Arraignment of Paris decried the 'atmosphere of petticoats and frills'. Witty his verses may have been, but they were not good-natured, as McKay describes them, any more than was Fairburn's denigration of what he called 'the menstrual school' of poetry (Whiteford, 2008).

With their patronising and chauvinist stance, Glover and Fairburn felt a need to promote an alternative in New Zealand literature and this was effected partly by the publications of the Caxton Press, which Glover established and ran. In 1943, Curnow sought Duggan's permission to include some of her poems in the anthology he was preparing, published in 1945 by the Caxton Press, but she refused. In 1948, Curnow again sought permission to include her work when the anthology was being revised, but again she declined. Curnow's judgement of her work in his introduction that 'the whole effect is that of an emotional cliché' (Curnow, 1951: 23) can hardly have encouraged her to participate. In a somewhat tetchy footnote to his discussion of Duggan in the same introduction Curnow notes: 'That is not to say there are not poems by Miss Duggan which I wished to include in this book; and they would have been included if she had not refused permission to reprint' (Curnow, 1951: 23).

Peter Whiteford writes:

Duggan continued to publish abroad and her reputation in England, Australia, and the United States remained high. However, something of the literary climate within which it was released may be gauged from an unpublished letter written by Fairburn to Charles Brasch, editor of 
Landfall at the time. Declining an invitation to review Duggan's 1951 More Poems, Fairburn was pleased to be relieved of 'the obligation to abuse a spinster. La Duggan's verse has never been much more to me than a distant mewing: I haven't read this latest book, but should be surprised to find it much different in texture and feeling from what went before it'. It is a far cry from the letter Fairburn wrote to Duggan in 1929, describing 'And at the End' as 'one of the greatest things l've ever read'. Had Fairburn read the new work, he might indeed have been surprised, for the volume represents, as E.H. McCormick notes, 'a remarkable achievement, the transformation in late maturity of long-established poetic habits in response to the pressure of inner experience'. (Whiteford, 2008)

After the publication of More Poems, Duggan stopped writing verse. Although she continued to earn her living through her prose writing for another twenty years, her poetry was silenced. In certain respects, the development of New Zealand poetry in the middle years of the twentieth century was closely bound up with the emergence of Modernism and issues of nationalism. Eileen Duggan was as impassioned about New Zealand as any of the generation of writers succeeding her, but she cared little for and actively resisted the Modernist movement, an example of her ideas about them can be found in her parody 'Shades of Maro of Toulouse':

Where are the words that broke the heart with beauty?

This is the age of the merely clever ...

[who] In one breath decry reason and avow it

Demand it of others but claim to transcend it

(Duggan, 1951: 17).

Whiteford (2008) contends that it may have been Duggan's misfortune to have been the last of the New Zealand pre-Modernist writers, but she was arguably also the most important, and most accomplished. Her subsequent absence from major anthologies was a result of her own decision, but it was a decision she felt forced to make by the prejudice and animosity she encountered. And it is this prejudice and animosity towards women poets and writers that is encountered throughout the timeframe of this thesis by male writers, poets, editors and male literary colleagues.

For Duggan the damage had been done and 'Shades of Maro of Toulouse' is a response to her 'clever' critics. This poem shows that Duggan 
was well versed in classical literature and her title 'Maro of Toulouse' echoes Virgil, sometimes known as Maro, who re-wrote 'Georgic' tales of idyllic settings, with echoes of Georgianism, is discussed later in this chapter in relation to the Georgian/Modernist debate. Duggan appears to be satiric when she advises her publisher to:

Change the name of the poem, 'Shades of Virgilius Maro' to 'Shades of Maro of Toulouse', since it is not the great Virgil but Maro of Toulouse who wrote 'A Secret Latin for the Initiates' (Duggan in Whiteford, 1994: 150).

On October $22^{\text {nd }}, 1972$, the literary community was shocked by the sudden death of poet James K. Baxter, whose death was a prominent national news item. Six weeks later, on December $10^{\text {th }}, 1972$, Eileen Duggan died quietly in Wellington hospital, her death overshadowed by that of the younger male poet. 'Ut per haec piae placationis officia perpetuam misercordiam consequatur Per Dominum nostrum ... so a woman's secret is different to a man's even unto death' (O'Leary, 1997: 27).

\section{'Ordinary' men}

T.H. Scott, in a long and much-cited essay in Landfall in the 1940s, backed by Rhodes and Monte Holcroft, held strong views about ordinary men. Scott argued that the works of New Zealand people were not 'scones, frocks or the raising of children, but houses, farms, roads, and bridges' (Scott in Jensen, 1996: 46). He did not comment on whether women enjoyed their role in having the babies, making the scones, and wearing the frocks. It is interesting to note here that, except perhaps for Glover during his wartime service in the merchant navy, none of these so-called 'ordinary men' had stereotypically masculine occupations.

Most of these men were either teachers, university lecturers or public service office workers: that is, they all had middle-class professional occupations. Jensen points out that when Scott writes of 'New Zealanders' he is thinking of 'New Zealand men' (Jensen, 1996: 46). Meanwhile, poet and 
historian Keith Sinclair would look back on Scott's essay as 'a kind of manifesto ... [that] made a powerful impression on some of us at the time (Sinclair, 1960: 182). So the stage was set in the 1930s for the battle between the sexes of the New Zealand literary scene in the post-war period. Gilbert and Curnow were miles apart. For him she was the archetypal woman poet, and as such he appears to have detested her.

Wright considers Gilbert was badmouthed by Curnow from 1947 onward, having been omitted from his anthologies and poorly treated by people under Curnow's influence, such as the early C. K. Stead and the early Vincent O'Sullivan, whose 1970 An Anthology of New Zealand Poetry seems flawed by her omission. Critics like C A Marris, John Schroder, Monte Holcroft, Denis Glover in private, Louis Johnson, Frank McKay. Peter Smart, Ian Wedde, Jenny Bornholdt, Terry Locke, Lauris Edmond, Joan Stevens, James Bertram, Riemke Ensing, and Helen Shaw all attested to Gilbert's merits, a better coverage of critical opinion than most local poets can claim (Wright, 2007).

Kite, the newsletter of the Association of New Zealand Literature, has under the editorship of Heather Murray only ever referred to Ruth Gilbert critically and Wright believes this is due to the lingering influence and authority of Curnow in its editorial circle. Wright stated he had praised Johnson as a critic and editor, but found his biggest lapse concerned Gilbert in 1957. Johnson published poems by both Macky and Gilbert in the New Zealand Poetry Yearbook of that year. However, the poem Johnson quotes in full is also in his bitter criticism of The Sunlit Hour in numbers 6. Wright notes that Gilbert also appears in New Zealand Poetry Yearbook Volume 7, 195758 with a poem later than The Sunlit Hour (Wright, 2007).

\section{numbers}

Even in the pre-1964 period the Wellington group without exception slowly surrendered their very obvious Georgian affinities. The first issue of a new literary review edited by Johnson, numbers 1, in July 1954 seemed to represent a changed attitude to the prevailing anti-women stance of the time. 
In a review of four recently published poems by women poets 'Women, God Bless 'Em' the reviewer 'Scruto' proclaims: 'There was a time, not long ago, when the price of serious writing in New Zealand - especially among women - was likely to be paid by way of dementia or at least ostracism' ('Scruto', 1954: 28).

But, by 1957, as is apparent in Johnson's hostile review in numbers 6 , March 1957 of Gilbert's The Sunlit Hour (1956), her first book of poems since 1949, Johnson seems to have fallen in line with Curnow's critical antiGeorgian stance. Johnson was as disrespectful in his numbers 6 review, to which Willow Macky responded in numbers 7. Johnson's review is evidence of the disputes discernible in the male/female poetic politics during the period. $^{6}$

Macky's criticism of Johnson's review appeared in her letter to numbers 7 followed by Johnson's reply. ${ }^{7}$ This battle seems to be at the nub of the differences I argue existed between men and women writers during the period, notwithstanding the fact that Johnson was one of the more sympathetic and supportive writers and publishers towards women writers. In 'Controversy: The Critic On The Mat' in numbers 7 Macky wrote 'the New Zealand reviewer is not in question, but it is obvious that they are almost completely lacking in understanding with regard to the woman writer $-\mathrm{a}$ fault far more evident in New Zealand than overseas' (Macky, Numbers 7, 1957: 26). Thus, even a sympathetic male like Johnson is seen by Macky as showing little understanding towards women writers.

It is interesting to note Gilbert's career after the 1950s. My analysis is informed by Wright's studies of her work. He notes that 'her poems appeared in the Anthology of Commonwealth Verse' (Wright, 2007: 10). Gilbert was a member of the New Zealand centre of the writers' organisation P.E.N. since 1950, was a past president, represented P.E.N. on the State Literary Fund Committee, and represented New Zealand at an international writer's congress in Dublin in 1953. American academic, Phyllis Ann French, writing a thesis on New Zealand women poets in the 1960s in 1967, 'Twelve Women Poets of New Zealand: imperatives of shape and growth', included Gilbert. 
Wright suggests, as a comment on the sex-poetry battle that by the mid1960s there may have been a cooling off as both men and women of the previous era came under threat from a new generation. ${ }^{8} \mathrm{He}$ argues:

in 1967 the 'Jessie Mackay Prize' was shared between Ruth Gilbert for The Luthier and James K. Baxter for Pig Island Letters. You can say therefore that down to that date a balance was being maintained and even a reconciliation was promoted by the powers that be. In fact the Baby Boom generation was just then arriving on the scene and while neither Baxter nor Gilbert was driven off the scene they were no longer centre stage. Baxter died in 1972 after a few years of his greatest public standing as a poet (Wright, 2007: 21-22).

Before her third 'Jessie Mackay Prize' was awarded Gilbert wrote to Wright in 1966 about the reviews of her book The Luthier. In the letter she stated:

I have been pleased with my 'Listener' Review \& not surprised at all by Louis Johnson's opinion in 'The Dominion'. Poor old Lou! I would need to change my sex to please him! (Gilbert in 'Among', 2007: 11).

Gilbert and Johnson appear to have become friends again later. Gilbert's work from the 1970s onwards and other commentaries reveal a life dedicated to poetry. At least Joan Stevens in the 1970 Contemporary Poets of the English Language, of which James Bertram was the New Zealand editor, endorsed her work.

Helen Shaw's anthology Mystical Choice (1981) includes Gilbert as did the selections of New Zealand poetry Helen Shaw guest edited in overseas literary magazines such as The Japonica Sings, May 1979. In The Journal of New Zealand Literature article by John Needham (1985; 3: 35-56) on 'Recent Poetry and Coleridgean Principles' examines the poetry of Gilbert. Her work was included in the Penguin Book of New Zealand Verse (1985), edited by Ian Wedde and Harvey McQueen.

In 1985 Wright published his survey of Gilbert's published poetry in Ruth Gilbert: An Account of Her Poetry, written as a review of her Collected Poems and included her annotations. Wright has since written a series of essays and notes commenting on Gilbert's career and poetry (see appendix 6). In Mary Paul's review in the Listener, 11 February, 1987, of Yellow 
Pencils, an anthology by Lydia Wevers, Paul asks why, if the anthology is meant to be inclusive, is Gilbert, who is still writing and publishing and has been in all the other anthologies, excluded?

In the Dominion, 18 September 1990, there was a letter to the editor by Gilbert defending Sylvia Ashton-Warner against a detractor who had referred to Ashton-Warner as 'selfish, arrogant, snobbish and anti-social'. She wrote: 'To those of us who knew her best, she remains what she always was: a warm, compassionate woman, an admired writer, and a loved and loving friend' (Gilbert, 2007: 46). It is interesting to note here that Ashton-Warner, in a 1967 letter to Gilbert, who had sent her a copy of her newly published The Luthier, wrote: 'I saw Louis Johnson's review in The Star. (Akld.) But whenever I see a review in N.Z. that is less than favourable ... I suspect a good book behind it ...' (Ashton-Warner, 1967: letter 1). ${ }^{9}$

From 1990 onwards Gilbert's work has begun to appear in more anthologies. They reflect the longevity of her poetry despite this earlier belittling by male critics and publishers of the 1950s and 1960s. The Feminist Companion to English Literature includes an entry on Gilbert. ${ }^{10}$ Gilbert's daughter, Deirdre Mackay, a reporter for the Nelson Mail, and author, wrote a lengthy profile of her mother (1991). Mackay gives an outline of her mother's literary life and her literary relationship with Ashton-Warner, Wright, Holcroft and Glover. ${ }^{11}$

Gilbert's publishing career continued and her Complete Early Poems, 1938-1944: with six later pieces were published by Original Books in Wellington in 1994. An anthology of love poems, My Heart Goes Swimming, compiled by Jenny Bornholdt and Gregory O'Brien in 1996, includes Gilbert. She appeared in The Oxford Anthology of New Zealand Poetry in English (1997) edited by Bornholdt, O'Brien and Mark Williams. The Oxford Companion to New Zealand Literature (1998) has an entry on Ruth Gilbert by Wright, who also published her Complete Sappho Poems in the same year.

One ironic aspect of Gilbert's career, domestic and literary, that brought her two worlds together happened at this time. In 1998 the tissue firm Snowtex issued 'The Poetry Series' on its packages, with a quote from Shelley and poems by Wordsworth, Gilbert, Katherine Mansfield and 
Shakespeare, putting Gilbert on a par with Mansfield, and both New Zealand women in the company of Britain's greatest poets. Gilbert appeared in Terry Locke's Jewels in the Water: contemporary New Zealand poetry for younger readers, published in 2000 and his anthology Doors: a Contemporary New Zealand Poetry Selection (2000) on which Wright commented to Gilbert as follows:

I have looked at Terry Locke's Doors. You will not have missed that [at 84] you are the oldest contributor, by four years with Rosalie Carey next. So it is indeed something that you appear in an anthology of CONTEMPORARY poetry in 2000. In fact it is pretty representative of poets publishing and active in the 1990's (Wright, 2007: 28-29).

In 2002 Gilbert was awarded Officer of the New Zealand Order of Merit for poetry. Anne Else (in Landfall 1985: 431-446) addresses the treatment reviewers gave to Gilbert. Gilbert turned 90 in 2007, and while she faced hostility from some male writers from 1943-1966, she was always respected among women writers. ${ }^{12}$

\section{Glover, Fairburn, Baxter}

Commenting on an oft-quoted epigram of Denis Glover's, Jensen writes:

I have several times heard Glover's deplorable jibe, 'Women poets: a bunch of bores in stuffy drawers', quoted as though definitive of his misogyny - yet he scrawled it on the back of the envelope in which he had just received an angry letter from Robin Hyde ... It's arguable, also, that Fairburn's and Glover's anti-feminist statements were part of the founding stage of their literary movement ... they mark the development of a literary culture in which women writers did not prosper; yet they are not typical. Perhaps the basic problem with either sex role theory or a monolithic patriarchal conspiracy is that neither theory reflects the complexity of human experience (Jensen, 1996: 9-10).

Chris Hilliard (2006) recalls that the scholars, critics, historians, librarians and literary lawyers were crucial gatekeepers of poetic taste and New Zealand's historical awareness 1920-1950, acting as go-betweens for writers, publishers and the New Zealand reading public. He also makes interesting 
use of international commentators on the New Zealand literary scene. For example, Hilliard writes:

The Australian critic Nettie Palmer championed [Eileen] Duggan, Jessie Mackay, and Katherine Mansfield in four separate articles from 1927 to 1930. Her husband, Vance Palmer, also praised Mackay, Duggan and Blanche Baughan ('there are no women writing more authentic poetry in English today'), as well as Mansfield and Mander. 'To an outsider,' he remarked, 'the most remarkable thing about Maoriland writing is the originality and strength of the women and the relative feebleness of the men (Hilliard, 2006: 35).

Hilliard's words suggest that there is no sign that 'Georgian' poetry had any connotations of effeminacy and the poetry of Jessie Mackay certainly did not seem soppy or twee to any bookman. Only the judgements and rhetoric of the next generation of 'literary men' would make the Georgian tradition seem 'feminine'. However, even now the perceptions of Georgianism are still negative and they sometimes appear 'in reviews to disparage those who write in ways regarded for the moment or from the perspective of the reviewer as old-fashioned' (Robinson, 1998: 200).

As opposed to the perceptions of women writers, the male writers of the 1940s, 1950s and the 1960s were prone to present themselves as practical men: as gardeners, printers, handymen. They liked to talk about writing as work or craft. Male writers projected the image of a masculine literature by their emphasis on hearty drinking. Jensen describes how Glover recalled the old Paekakariki Pub on the Kapiti Coast north of Wellington with considerable reverence, as a link in the chain of male drinking institutions, hotels and the like throughout the country and the world when he was in the Merchant Navy during WW2.

In fact, Glover is quoted in his memoir as saying, somewhat romantically, nostalgically, and a trifle disingenuously: 'One must regret those days, when there were no women [in the pub], no altercations, no knives or bottle-bashings ...' (Glover, 1981: 241). Sargeson recalled the 1951 Writers' Conference as 'all very enlivening: literary chatter, politics, anecdotes: the full range from bawdy stories to learned epigrams that accompanied the beer in the out-of-the-way after-hours pub' (Sargeson, 1981: 357). Jensen asks how 
many writers in these after-hours pub sessions were women? The answer is probably none, but if there were did they inhibit the bawdiness of the stories? Could the few women writers who appear in the 1951 conference photograph participate fully in its life as described above by Sargeson? Jensen quotes Glover's poem 'To a woman shopping':

\author{
What's death to the lady, pray? \\ Even shopping's a bore \\ - The carcasses gently sway \\ As she goes out the door
But death goes with her on her way In her basket along the street Rolls heavily against her thigh The blood-red bud of the meat (Glover, 1981: 33).

Notwithstanding the sexual innuendo of the last two lines, would Glover write a poem about a man going to buy meat at the butchers? The subjects of death, meat, and carcasses leads to the topic of male violence in New Zealand literature.

Kendrick Smithyman, discussing New Zealand poetry in 1965, quoted Lionel Trilling on the 'powerful and obsessive significance that violence has for the intellectual' (Trilling in Smithyman, 1965: 183). It's likely the intellectual he has in mind is male, and for New Zealand male intellectuals in the mid-twentieth century, death and violence were of particular interest for their masculine connotations. Literature that focused on these topics could present itself as a serious business, the work of 'responsible adult New Zealanders' (Jensen, 1996: 42).

Another topic that could be said to characterise the new literature was that of the 'man alone'. Baxter suggested this was the distinguishing mark of the 1930s and 1940s. In his 1954 lecture series, later published as The Fire and the Anvil, he wrote:

The anxiety, however, which accompanies the taking on of this role is a different matter. It seems to derive from the artist's awareness that his activity is regarded with indifference or even hostility by the society in 
which he lives. The symbol of Man Alone is thus objectified as the hobo, the social outcast, standing for the outcast energies, both criminal and creative, which the artist tries to reintegrate in his view of the world. (Baxter, 1957: 72).

Fairburn appears to turn these arguments upside down by claiming that:

Women have little or no moral courage, because they do not understand what it means; just as men are, on the whole, deficient in biological courage ... a man will always be tempted to consider sensual enjoyment, or the accumulation of power, or (more rarely) self-sacrifice to an idea, as being at least as important as the pursuit of simple biological ends. The normal woman is never in doubt about such things. It is the abnormal woman, the blue-stocking or male impersonator of some kind or other, who (under masculine influence of some sort) can interest herself in the things of the spirit (Fairburn, 1967: 20).

The irony of putting the Baxter and Fairburn quotes together is that they show up the male poet's difficulty in attempting to accommodate the female element or the female person in life and literature.

From Baxter's understanding it would appear that women represent the 'social norm', whereas in Fairburn it looks as if the female element is the untamed and amoral member of society, and men are the reasoned, intellectual and spiritual 'higher beings'. These ideas of women can be found elsewhere in the male literary litany of American and European thought at this time of the early and mid-twentieth century. For example, E. Fuller Torrey (1984) on Ezra Pound states: 'Pound's prose and poetry written during the Rapallo years [1920s and 1930s] enlarged on the sexual theories he had previously explored. Woman is viewed as a primitive creature, a kind of primordial biological receptacle' (Torrey, 1984: 128).

Chiefist of these the second, the female

Is an element, the female

Is a chaos

An Octopus

A biological process

and we seek to fulfil ...

She is a submarine, she is an octopus, she is

A biological process 
(Pound in Torrey, 1984: 128).

However, some poetry written by men was at the heart of their criticism of others. For example, what Jensen refers to as one of Fairburn's 'limpist' epigrams, 'Any-Book-of-the-Month-Club':

The virgin marks her calendar and still goes undefiled she menstruates most regular and never has a child (Fairburn in Jensen, 1996: 89).

This negative comment on women writers and readers groups, and on spinsters, was admired by literary critic James Bertram: '[If] any New Zealand epigram deserves to stand with the best of Roy Campbell', wrote Bertram, 'it is surely [this one]' (Bertram in Jensen, 1996: 89). Baxter admired the bawdiness and irreverence of Fairburn's and Glover's lighter verse and of prose writers who tried to suggest the bawdiness of slang in all-male situations; in war literature this was taken a lot further. Also, in rugby changing rooms, both bawdiness and homophobia are dealt with, along with issues of Māori and Pākehā relations.

There seems little place for women in either the literary or real lives of these artists and human beings. As Jensen points out, alongside the 'manly' qualities of rough talk and expressing the language of ordinary workers, soldiers etc. this group also put great store in writing being both literary and intellectual, which equated with masculinity. He points out that Curnow and others claimed good writing was defined by intellect. Curnow admired the 'masculine erudition' of Wallace Stevens. Fairburn (1967) observed that Eileen Duggan and other Georgian, that is women, writers were highly competent, but lacking in any one of the essential qualities that make good poetry - brains, bile, guts and so on'.

Wealth of vocabulary and deftness in using difficult forms [of poetry] were also described in terms of masculinity. In his literary satire The Arraignment of Paris Glover compares the effeminate poets of the Best Poets group with his own, more manly poetry comrades who can: 
... leap a five-barred gate of rhyme and still keep on whistling all the time while Paris and his valiant spinster crew assault a common stile and then cry 'Phew!' (Glover, 1981: 11)

Jensen concludes that the male writers used metaphors to describe literary attributes such as vigour, strength (key nouns), rough, robust (key adjectives). In contrast bad writing was weak, slack, feeble, sickly. He says that Fairburn seemed to lose the distinction between metaphors of masculine physique and the reality that good writing might be produced by frail or homosexual men, or by women, and Fairburn went so far as to say that most of the love songs written in the previous twenty years suggested either impotence or homosexuality (there is no mention of women here at all).

While discussing a poem in Baxter's Blow, Wind of Fruitfulness Curnow noted 'a welcome gain in irony and detachment, a more muscular growth in Mr Baxter's thought' (Curnow in Jensen, 1996: 76). Curnow, in an introduction to R.A.K. Mason's Collected Poems admired 'the supple movement of their syntax, the muscle and bone of a living speech, they waken the mind to share the unique vision of a poet' (Curnow, 1963: 11). Thus the negative version of the above becomes weakness, slightness or fatness. In his attack on Louis Johnson's 1952 Poetry Yearbook Curnow says it is a 'fatty degeneration of the verse, lacking in nerve and sinew' (Curnow, 1987: 111). According to Curnow, 'nineteenth century New Zealand poetry was the voice of Alfred Lord Tennyson, thinned and grown womanish' (Curnow, 1987: 33), another derogatorary remark equating femaleness with weakness.

The Masculinists differentiated their own 'male' literature by trying to characterize New Zealand literature of the previous period as being effeminate and having been mainly written by women. And while it is true that many of New Zealand's best writers in the first three decades of the twentieth century were women (Mansfield, Mander, Devanny, Baughan, Bethell, Duggan) it did not translate into a preponderance of women writers in terms of numbers. 
For example, Lauris Edmond counts women as being fewer than half of the contributors to Marris's 1934 Best Poems series, and about a third of the 1935 edition, and in Quentin Pope's Kowhai Gold it was roughly half-andhalf. Despite these figures Glover felt it necessary to depict Marris (Paris) as an effeminate male leading a troupe of women through a 'tough' landscape they knew nothing about and Sargeson also used satire to belittle the 'Lady Poet'. Curnow argued against the inclusion of '[hobbyists] and amateurs' observing that eighteen out of thirty-five new contributors had been women, thus equating amateurism with female gender.

Summing up the male writers' attitudes during this period, Jensen argues they sought to generate a powerful, realistic masculine literature - at the cost of contemporary women writers, and of women in general, and that the Tomorrow and Phoenix magazines laid much of the foundations for the masculinists' philosophy to flourish, along with the introduction of the Caxton Press. Fairburn begins taunting the Georgians by satirizing the Kowhai Gold anthology - 'the bloom of the Kowhai has fallen, girls/did somebody give it a push?' (Fairburn, 1967: 136). These attitudes grew through the 1930s and 1940s until, in 1950, Brasch was talking of 'those would-be poets, most of them long since silent, withered no doubt by that cold blast of reality the depression, whose work was collected in an anthology called Kowhai Gold" (Brasch, 1981: 164).

The masculinists had the advantage of the kind of close-knit, supportive community that feminist writers, Māori writers and post-modern text-art writers have enjoyed in recent decades and the masculinists were all enthusiastic young men who were excited by what they were doing. However, the downside of their enthusiasm is seen in Curnow's continuation of his defensive criticism long after the need, and by the end of the 1960s things were about to change. Evans in his Penguin History of New Zealand Literature notes that:

For middle-class males of that post-war generation, literature was a heritage, something they came to naturally around the middle of the Sixties and began to use without question ... But for women and for Māori and for Māori women, the literary heritage was something that 
belonged to men. 'In the 50 s and 60 s, while other writers of my generation were sharing their experiments and publishing one another's work,' said Lauris Edmond (1924), a writer who began publishing in her fifties, 'I was living in country towns completely involved in bringing up my large family' (Evans, 1990: 215).

The evidence presented in this chapter suggests that the women poets of the post-war era, from 1945 to 1970 were disadvantaged simply by being women. The example of Gilbert and the disparaging attitude towards her as a poet and the resentment this engendered in her and other women of the period towards their male counterparts illustrates this. Remarks by many of the male poets towards women writers cannot be shrugged off as mere playfulness or banter but it may be argued that they portray a distrust and misogyny within the male literary fraternity. Because the male writers at the time were also often the editors and publishers of the literary magazines and journals, and therefore the gatekeepers of style and content, their attitudes towards the women poets and writers affected whether those women were published. In the following chapter on women novelists I discuss how some of the issues and struggles were different to those of the women poets.

\footnotetext{
${ }^{1}$ Brasch, in his 1962 publication, Landfall Country which was described on the dust jacket as being 'a remarkable picture of New Zealand achievement in literature and painting. Further, it offers a view of the emerging character of life here as seen through the eyes of the most perceptive writers and artists ...' Out of the 36 entries in the writers section, 5 were women. The artists fared somewhat better, with 10 pieces by women out of 22 art works.

211 November 1949, p9.

${ }^{3}$ Gilbert, R: newspaper article, 1966, 'Hard Lines for Women Writers.'

${ }^{4}$ Frame's mother Lottie Frame wrote poetry. According to King: 'One visitor [Majorie Hore] reported, in a horrified tone, that she had called upon "Mrs Frame" one afternoon and found her "sitting at the kitchen table, scribbling poetry on an envelope, surrounded by dirty dishes and flies - well ..." This was not "normal" behaviour in a New Zealand town in the 1930s where, even amid poverty, pretension and social ambition were rife, and women's domestic reputations were made or broken according to whether or not they scrubbed their front doorsteps' (King, 2000: 31).

${ }^{5}$ Lawlor was a supporter of women writers and 'chaired the first meeting of the [New Zealand Women's Writers'] Society [in 1932] convened by Nellie Donovan and until his death at the age of 86 in 1979, he kept up his interest and encouragement and
} 
was affectionately known as "the father of the Society" ... he was elected and Hon. Vice-President of our Society in 1977, the first [and only] male to hold this position' (France et al, 1982: 5).

${ }^{6}$ See Appendix 11 for the full text of Johnson's review.

${ }^{7}$ See Appendix 12 for the full text of Macky's letter and Johnson's reply.

${ }^{8}$ Even later anthologies, in so-called liberated times, have tended to consolidate this difference. For example, Brunton, Edmond \& Leggott, Big Smoke (New Zealand Poems 1960 to 1975) had 38 entries by men and 18 by women. This was even more pronounced in Arthur Baysting's 1973 anthology The Young New Zealand Poets which had 18 male poets and only 1 female poet, Jan Kemp.

${ }^{9}$ See for relevant remarks also WHENUA: the letters of Sylvia Ashton-Warner to Ruth Gilbert 1967-1984, available in the Turnbull Library.

${ }^{10}$ Copy of article in Wright 2002/H. Though cited, Wright was not its author.

${ }^{11}$ Deirdre Mackay writes: A bonus from writing (i.e. her mother's writing) was the friendships with other writers and publishers which developed with time. 'We used to visit Denis Glover at Paekakariki and had hilarious afternoons discussing writers and writing. Denis was a wonderful mimic and would have everyone laughing.' She (Ruth Gilbert) and Denis had more serious discussions about the nature of poetry too. [Gilbert says] 'We agreed that what makes a poem is magic. This can't be defined but you know it when you find it.' Thus, despite often overtly sexist proclamations by Glover et al the men and women poets found common ground at times.

${ }^{12}$ See the e-mail correspondence between the American poet, Cameron La Follette and Niel Wright in the 'Cameron La Follette' Appendix 8 to this thesis. 


\section{Chapter 6}

\section{Women Novelists}

This chapter considers the background to the period 1945-1970 of the ideas and realities experienced by women writers of prose. It explores the effects of World War Two on the psyche of the male writers in the post-war period, looking at some of the underlying resentments and frustrations of returning soldiers and the effects these may have had on men's attitudes towards women. I then consider the writing careers of five women and discuss the effect of some prevailing attitudes on their writing styles and careers generally. I discuss each author to assess whether aspects of their personal lives, their family backgrounds and beliefs contributed to their literary ambitions.

The chapter includes Rosemary Rees, Ngaio Marsh, Dorothy Quentin, Dorothy Eden, Janet Frame, and mentions other women writers of fiction. Despite assumptions that women were not prominent in the 1940s to 1970 s period, it appears at first that these women novelists were among the most successful New Zealand writers of the period both in terms of commercial success and literary note. ${ }^{1}$ They were among the most prolific in terms of numbers of publications, works translated into other languages, numbers of editions, and serialisation of individual titles, and began to supersede their male counterparts in these areas. However, while this may seem contradictory to my argument it will be seen that such achievements during the period were mainly recognised and realised overseas, Frame being an exception. But many of the women writers, such as Marsh, felt they were not taken seriously in New Zealand despite international recognition and success.

Until the 1940s men and women shared a reasonably equal publishing ratio in New Zealand, sometimes only one or two titles separating them in terms of numbers of books published within any given year or decade, although up until the 1920s the men tended to dominate. From the 1920s onwards through to the 1970 s there is not one decade when women 
novelists did not outdo men in terms of publication numbers, although within some years this tended to move either way. The 1960s saw the widest gap in numbers, with women having 180 works of fiction published to the 134 published by men. However, in 1961 there were 4 books by women and 9 by men, and in 196712 by women and 13 by men. The overall picture of the decade is clear, yet it did not translate into critical acclaim or literary acceptance.

\section{The effect of WW2}

Jensen writes that the farmer and the workingman distilled a new national identity, but were also potential readers, who might recognize in the new writing 'their own authentic voice' (Jensen, 1996: 47). Excited by this hope, male writers of the day emphasized the hidden sensitivity and potential literacy of the practical man. For example, Sargeson described his uncle, Oakley Sargeson, as highly perceptive and noted that, although he was a struggling farmer with only primary school education, he was better read than Sargeson himself at that time. ${ }^{2}$

Jensen discusses WW2 and how 'it seemed that the war gave a powerful boost to the new male writers' (Jensen, 1996: 59). In 1945 Caxton published a short story anthology edited by Sargeson, Speaking for ourselves. Frame in her autobiography would record how, on reading this book at the close of the war, she felt 'the excitement of being in a land that was coming alive with its own writing, speaking for itself, with many of the writers returning from the war, bringing their urgency of experience' (Frame, 1991: 200).

It is assumed that wartime urgency of experience could be brought back only by male writers. This was not strictly true as most of the nurses looking after the wounded were women, who would have seen much of the consequences of the war on people despite not having been involved in the fighting. However, some war literature was the result of misogynist thought. One example already mentioned is Guthrie Wilson's novel, Brave Company, 
where a nurse suggests that the battle for Casino was a failure by New Zealand Division troops, where Wilson comments on this character:

This of all insults is the least forgivable. Casino is very much a bitter and painful memory, not of defeat, but of costly frustration.

'The bitch should be strangled!' is Donald's solution.

But Mitchison would accord her a useful death the nature of which cannot be here recorded (Wilson, 1962: 100).

The vitriolic reply to her accusations when the men are alone infers that she should be raped to death for her insults. Thus, 'Masculine' activities and disclaimers of literary status were two characteristic behaviours of male writers in the 1930s and 1940s and a masculine mythology was burgeoning in the literary community, as writers sought to close the gap between themselves and ordinary or manly New Zealand men. Writing itself had to be masculinized, in both material and style.

By 1940 the masculine literary movement had arrived, both in poetry and prose. Jensen argues that the beginning of the prose 'revolution' vis-àvis the masculinist movement may have actually been started by Sargeson copying the style of a one page story published in the first issue of Tomorrow magazine, and that the story was by a woman writer, Alice M. Henderson (Jensen, 1996: 87). In his autobiography Sargeson gives credence to this possibility. He writes:

Whether it was chance or influence or both I do not know, but about the time of my meeting with Fairburn I saw a copy of Tomorrow for the first time, and immediately wrote something which I could very surely recognise as quite different from anything I had written previously ... (Sargeson, 1981: 180).

After forging a new style of writing by 'combining form, style and range of material to suit a developing literary milieu, Sargeson's stories were heavily influential on other New Zealand writers of prose fiction: David Ballantyne, John Reece Cole, Davin, Finlayson, Gaskell' (Jensen, 1996: 87).

It is ironic that Sargeson, hailed as the first New Zealander to write as a real 'New Zealand Man' was a male homosexual and that he seems to have copied the original style and idea from a woman writer. It was Sargeson's use 
of colloquial New Zealand bar room working 'man's' language that, according to Fairburn, had given New Zealand literature something of the 'normal' New Zealander (Fairburn, 1967). Copland was amazed to find in Sargeson 'the mother tongue of Waipukurau and Eketahuna'. In 1948 Sargeson referred to Mansfield as 'very much indeed in the feminine tradition' which he equated with 'the minor tradition ... a tendency to be concerned with the part rather than the whole' (Sargeson, 1983: 30) and Dan Davin through his character Cody, says of KM 'She's a bit doll's house for me. The scale's too small' (Davin, 1970: 177). That Mansfield is considered one of our finest and bestknown writers, both in New Zealand and internationally, is dismissed.

Examples of the common tongue in poetry of ordinary people [that is, men] by Curnow and Glover are seen as progress from the 'lofty heights' of feminine/Georgian language, while a group of feminist critics, less sympathetically, talk of 'that harsh, laconic, bitten-off masculine dialect that Sargeson and Mulgan ... installed as the dominant discourse of New Zealand fiction' (Jensen, 1996: 71). Thus, both poetry and prose were affected by the masculinist philosophy. In fact, the whole of New Zealand literary expression appears to be under this masculinist influence. In Denys Trussell's biography of Fairburn he says that 'Literary' was almost a dirty word in Fairburn's correspondence with Glover. However, Fairburn praised Jane Mander as being worth any four other literary women in this country. He said of her that she's a woman; and she's not 'literary' (Fairburn in Trussell, 1984: 170).

As already alluded to, male writers of the period were at pains to identify with men who worked at manual labour. Thus, large groups of working men constituted the desired masculine location. For example, Bertram observed of Davin's novel Roads from Home that the New Zealand Railways plays a part not unlike that of the New Zealand Division in the war stories, a brotherhood of tough workingmen whose daily tasks involve strength, courage and the continual risk of sudden death or disabling accident. ${ }^{3}$ And in Bill Pearson's novel Coal Flat the miners' union is yet another vision of healthy masculine community, a welcome contrast to Ma Palmer's overwhelming dominance of the family at the pub. As Davin indicates, it was 
the language of the soldier and the football team, thus the world of ordinary men:

In the Irish way, and in the way of gregarious writers everywhere, he had always made much use of alcohol and pubs, was at home in them sometimes more than it seemed than he was at home. He never sought an exclusively literary company ... He liked men of strength and courage, hard men. But often in these later years the hard men were the hard drinkers. (Davin, 1985: 59)

War literature was an extreme version of the overall tendency to depict women as outside literary concerns. Fairburn argues that equality between the sexes 'was a 'sentimental' and 'romantic' heresy, spread by feminists and homosexuals'. Even when considered as satirical, this stance underlines a misogynist attitude, as previously he thought that women are inherently immoral and anti-social, that they have little notion of abstract justice and are incapable of principles. Women, he says, can act without moral consideration and are irrational:

maintaining an objective and disinterested habit of thought [was difficult enough for a man] for women it is almost impossible ... Women's minds are not designed for the purpose of making judgements on matters that call for objective consideration ... [Women who had] acquired certain masculine habits of mind, through their association with intelligent men [might be] most charming, [but were] usually marginal creatures in the book of Genesis (Fairburn, 1967: 18-20).

Although Glover and Fairburn represent the extreme ideals of the 'masculinists' their aggressively masculine postures served the group purpose of making literature seem masculine. Summing up the male writers' attitudes during most of the period this thesis covers, Jensen thinks male writers sought to 'generate a powerful, realistic masculine literature - at the cost of contemporary women writers, and of women in general' (Jensen, 1996: 80-81).

Curnow, in a review of Pearson's Coal Flat, attacked Ashton-Warner's main character in Spinster, as 'the ... egomaniac Vorontosov rhapsody' (Curnow, 1963). Jensen notes that of the two it is Ashton-Warner's novel that stands the test of time and that his attack emphasises Curnow's blind spot 
when it came to reviewing books that didn't fit into the masculinist theory. $\mathrm{He}$ regards Ashton-Warner's novel as having 'more staying power, even though it describes the interior life of an aging, alcoholic woman' (Jensen, 1996: 91).

The idea that male writers should identify with the ordinary man began to develop another side that showed a certain disenchantment with this stance. C.K. Stead tells a story of when Maurice Duggan was with literary friends in a bar a Māori man came up and said: 'You a Kiwi, mate?' Duggan responded with 'Yes mate, are you?' (Stead, 1989: 133). Thus the writer challenged an ordinary working man (a Māori at that) on the idea of national identity. If the writer had needed to become more masculine, the ordinary man had to become more emotionally expressive.

To the writers and intellectuals the 'real men' weren't playing ball. Pearson wrote of the intolerance of the 'ordinary man' towards artists, who sought to enrich New Zealand society. Pearson argued:

When the man-in-the-pub speaks his feelings he reduces them to a common denominator; he avoids distinction and definition in expression; tragedy is 'tough luck', disappointment 'a bit of a bastard' (Pearson, 1962: 342).

Implicit in Pearson's discussion is the idea of the artist as heroic, as being more masculine than other men, who are effeminate because they submit to convention. The above shows a confused aspect of the male writers' position.

Romance writing by women has often been portrayed as inferior and of slight literary worth. Of the five following case studies, three of the women can be classed as romance writers. However, outward appearances can be deceiving. American academic, Janice Radway, in her 1984 ground breaking study of 'Romance' books, Reading the Romance, analyzes the genre by examining the language of the romance novel and how that language affects the readers. Among those who have disparaged romance reading are feminists, literary critics, and theorists of mass culture who claim that romances reinforce the woman reader's dependence on men and acceptance of the repressive ideology purveyed by popular culture. Radway 
was the first serious writer to question such claims, arguing that critical attention 'must shift from the text itself, taken in isolation, to the complex social event of reading' (Radway: 1984).

She examines the complicated business of publishing one of the most lucrative categories in the industry and its distribution, to the individual reader's engagement with the text. The style, Radway points out, is relatively simplistic. She describes it as dominated by cliché, simple vocabulary and standard syntax, and compares it to the nineteenth-century realist novel. Unlike New Zealand academic Joan Stevens, however, who sees this as a fault with romance writing, Radway argues that these methods allow romance novels to be easily read, and are not just a sacrificing of artistic ability (Radway 1984). Thus the successful, fulfilling romance novel exists, she continues, when the author herself has provided meaning for her story through the words she has written. In an introduction to the 1987 British edition of her book, republished in "Reading Reading the Romance", Radway discussed the women she interviewed for her original book:

They repeatedly explained their reading as a way of temporarily refusing the demands associated with their role as wives and mothers; they said that romance reading functioned as a 'declaration of independence', as a way of securing privacy while at the same time providing companionship and conversation. In this way, I unpack the significance of the word 'escape' ... The simple act of reading a book serves as a way of declaring themselves off-limits. I try to make the case for seeing romance reading as a form of resistance to a situation predicated on the assumption that women alone are responsible for the care and the emotional nurturance of others. For them, romance reading creates a feeling of hope ... How did the heroine's experience foster their ability to see the heroine's story as interesting and how did it account for their willingness to see their own pleasure through the heroine's at the moment when they were directly confronting their dissatisfaction with traditionally structured heterosexual relationships? (Radway, 1997: 71).

\section{Mary Scott, Joyce West \& Nelle Scanlan}

In her 1961 study of the New Zealand novel, Stevens writes that the 'basic defect of light fiction is, of course, that its development is according to pattern'. She goes on to imply that this kind of writing lacks development of 
plot and character and its main aim is to fulfil the need of the popular market. She concludes that while such works may be quietly perceptive and amusing, they deal 'exclusively with personal relationships within a feminine world, they are aimed at readers not minded to struggle with intellectual concepts or difficult imaginative pressures' (Stevens, 1961:44). This idea of 'feminine thought' being somehow lightweight and inconsequential appears to be the underwritten criticism of the period, even from another woman and particularly from the masculinists.

However, Stevens and to a certain extent J.C. Reid, deserve some credit for being among the first literary academics in New Zealand universities to actually encourage discussion on New Zealand literature. However, the fact that Reid's book was self-published and Stevens' was essentially published with a non-university audience in mind, indicates that studying New Zealand literature was seen as somehow low-brow or not worthy of serious discussion.

The same can be said for the teaching of New Zealand history at the time and even until quite recently historians took little interest in New Zealand social history. Historian Jock Phillips, in acknowledging this lack before the 1990 New Zealand sesquicentennial, pointed out that though New Zealanders were 'hungry for useful information about the evolution of their ways of life ... what history could we give them?' (Phillips, 1990: 119). Phillips added that our 'cultural cringe' meant that British history was the focus of university history courses, and undergraduate New Zealand history was not taught until the 1960s (Phillips, 1990). It is interesting to note that the New Zealand Journal of History only began in 1967, and the New Zealand Historical Association in 1979 (Phillips 1990). Since the 1993 New Zealand women's suffrage centennial year, there has been a growth in interest in New Zealand women's history.

It is not until critics like Lydia Wevers and Terry Sturm wrote on the subject in the 1980s and the 1990s that a wider ranging assessment of the women writers of the 1945 to 1970 period saw their work as a positive and necessary part of the development of the New Zealand literary canon as a whole. Mary Scott (née Clarke) was born in 1888 and died in 1979. She 
attended Auckland University College in 1905 to study English, French and History. She graduated MA in English and French, with first-class honours. In the late 1920s Mary Scott decided to start writing, sending articles and stories to magazines and newspapers.

Scott contributed a weekly item to the Dunedin Evening Star, for which she was to write for almost 50 years. Wevers writing on Scott states: 'her first two novels, published under the pseudonym Marten Stuart: Where the apple reddens in 1934 and the following year And shadows flee. These were historical romances set in the far north of early nineteenth century New Zealand' (Wevers, DNZB website). Stevens refers to these two novels as being 'more melodramatic' (Stevens, 1961:45) than her later novels which were published under her own name and were more realistic and humorous, which lifted her novels above the usual label of 'just romance'.

Terry Sturm wrote that Scott was the 'first popular novelist to set all her fiction in New Zealand and to think of her readership as primarily a New Zealand one (Sturm, OCNZL: 485). Scott's autobiography, Days that have been (1966), and her serious novel, The unwritten book (1957), both tell a grimmer story of life in the bush than her popular novels, but all her work stresses the value of bush community and explores the tensions between town and country. She became widely read both in New Zealand and overseas. Many of her books were translated into several languages (like many of the NZ women novelists of the time, for examples see the bibliographical material in the appendices on Eden, Quentin et al) and several became bestsellers in Germany. Scott wrote three collections of plays for country women's institutes, 33 novels, and a monograph under the pen-name J. Fiat.

Included in Scott's novels are five thrillers written with Joyce West (1908-1985). Fatal Lady (1960), Such Nice People (1962), Mangrove Murder (1963), No Red Herrings, (1964), and Who Put it There? (1965). This is extraordinary in itself, as such collaborations (OCNZL) are rare even in producing one book. Stevens has written of West's novel Sheep Kings that her material used fresh subject matter 'and she has a keen sense of the drama' (Stevens, 1961: 49). One of West's best-known works is her 
children's trilogy Drovers Road (1953), a tale of family life on a New Zealand sheep station, which was followed by two sequels Cape Lost (1963) and The Golden Country (1965). West illustrated several of her books with her own ink drawings and contributed poetry and articles to the New Zealand Railways Magazine. West's novel The Sea Islanders (1970) was turned into a five-part British TV series Jackanory.

Nelle Scanlan (1882-1068) worked as a journalist both in New Zealand and overseas. She wrote 15 novels, the most famous of which are the four 'Pencarrow' stories These books established Scanlan as the most popular New Zealand novelist of her generation (DNZB), and in 1963 she published her autobiography, Road to Pencarrow, in which she wrote somewhat ruefully: 'I was never young and full of promise. I was once young, but my first novel wasn't published until I was nearly fifty' (Scanlan, DNZB website: no pagination). Author Alan Mulgan is cited as describing Scanlan as 'a writer who was influential in the 1930s and 1940s in creating a readership for New Zealand fiction, changing negative colonial attitudes towards locally written work' (Sturm, OCNZL: 478).

The following examples illustrate the extent of women novelists' influence, three of whom are 'Romance' writers, in New Zealand literature in the period 1945 to 1970 , both in personal contribution through bibliographical content, and the diversity of their personal lives as an expression of New Zealand life. Each highlights the success of these women writers during the period in either literary or commercial literature, and sometimes both. They appear in chronological order of birth and most have careers extending across the whole period of $1945-1970$.

\section{Rosemary Frances Rees: 1876-1963}

The cover blurb for Rosemary Rees' 1928 novel Wild, Wild Heart, read:

Miss Rosemary Rees owes her wide popularity in Great Britain and the Colonies to her splendid sense of the open-air life, her understanding of the manly types of manhood and of lovable and unaffected women. She sets the scene of her love stories among natural surroundings, where 
the promptings of the heart are not checked by convention or pretence. Her men are true men, and her women true women ...

Rosemary Frances Rees was the daughter of Hannah (Annie) Elizabeth Staite and William Lee Rees, the youngest of their seven children. Her sister Elizabeth Pococke ('Bessie') Rees (Mrs Hugh Lusk) was also a writer, publishing six novels as 'Elizabeth Milton' between 1929 and 1936. In addition to writing novels, Rosemary Rees was an actress, theatre producer and playwright. In her entry on Rees for the Dictionary of New Zealand Biography Nancy Swarbrick quotes her as saying 'my sole and fervent ambition was to act' (Swarbrick, DNZB website: 2007). Swarbrick reports that around 1900 Rees went to London to join the company of comedienne Fanny Brough. Subsequently Rees obtained roles with touring repertory companies and wrote short stories for London journals, and several of her one-act plays were staged as curtain raisers.

Rees described herself, as previously suggested somewhat selfdisparagingly, as 'the 'best selling' New Zealand author and there is little question of her international reputation as a romance novelist. Patricia Mill, in an interview with Rees in Gisborne in the late 1950s reports that Rees told her that her first novel was 'finished in five-hand-cramping weeks'. Rees explained: 'I wish I could write more solid stuff. I know that my own works are neither profound nor thought-provoking; they are really only very light amusement' (Mill, 1957: 11). However, Terry Sturm calls her: 'a key transitional figure in the emergence of the light romance in New Zealand ...' (Sturm, 1998: 587).

Hyde, who met Rees in 1936, called her likeable and clever, and Rees indicated to Hyde that she knew exactly where she stood and how she was thought of by the literary establishment. Hyde said Rees 'made no bones about writing to sell' ... Rees then told Hyde: 'The Highbrows take themselves much too seriously. Come along and have a cup of tea' (Roberts [Heather], 1992: 553). Rees had a lengthy writing career during which she produced 24 romantic novels, ${ }^{4}$ and Nancy Swarbrick, writing about these books, explains: 
Some were serialised in major English and American papers before appearing as books, several were published in America (under different titles), and there were numerous reprints and translations. Many had New Zealand settings; this fact and a large local readership established Rees as a key figure in the development of indigenous light romance. The novels were, however, unremarkable: racy dialogue and engaging characters failed to conceal their contrived and predictable plots (Swarbrick, DNZB: 2007).

This, despite the fact that early in her career the 'Boston Transcript' reviewing Dear Acquaintance suggested Rees had an emotional gift that the reviewer thought should prove her stepping stone to more lasting literature. Joan Stevens comments of Rees' writings that:

Nevertheless, such stories have their place in this account of New Zealand fiction. No national literature grows up over night ... the stereotyped characters and the imposed patterns of romance in the novels of Rosemary Rees do not entirely prohibit some good New Zealand touches, and some truthful descriptions of men and things (Stevens, 1966: 43).

Reid, however, states:

In the field of popular writing, that demi-monde of letters, women are again to the fore. One of the most popular is Rosemary Rees whose books are only superficially New Zealand novels, for, while she is strong on 'local colour', the values and manners of her characters are English middle-class (Reid, 1946: 57).

Three years before Reid's comment, Alan Mulgan said of Rees that her novels 'did something to break down this indifference [to New Zealand settings]' (Mulgan, 1943: 25). It is interesting to note here, that a novel begun in the early 1920 s by Ngaio Marsh was set with 'a New Zealand backdrop'.

By the late 1950s Rees was dealing with complex issues in New Zealand's past and her use of local settings had become quite personal also. For example under the heading 'Gisborne romance' the New Zealand Weekly News mentions Rees' forthcoming novel Love in a Lonely Land as '...set in Gisborne ... [the] story disguises the town in its pioneering era under the name of Gladstone soon after the Te Kooti massacre ...' (Weekly News, 3 Sept 1958: 15). However, in retirement she was ambivalent: she felt in 'rather 
a backwater in Poverty Bay - sun and fruit and flowers, but not the stimulation of new ideas' (Rees in Swarbrick, DNZB: 2007). But a return visit to London in 1957 and celebrity status in the local community provided some compensation. Rees continued to publish novels until about a year before her death, her last being The Proud Diana in 1962.

\section{Edith Ngaio Marsh: 1895-1982}

Ngaio Marsh was seven years old when her parents moved to Valley Road, Cashmere. The house her father built there was to be her home for the rest of her life. She was educated first at a dame school run by Sibella E. Ross, and then in 1910 enrolled at St Margaret's College, a private Anglican girls' school with an Anglo-Catholic bias, where she remained until 1913, active in literary and dramatic pursuits. Her play The Moon Princess was performed that year, with her mother taking the part of the witch. The Christchurch Press described it as 'a clever little play', and Marsh herself wrote: 'In the event, it went quite well and drew good audiences' (Marsh, 1966: 81), despite some juvenile misgivings.

Between 1913 and 1919 Marsh attended Canterbury College School of Art as a part-time student, supplementing her income with private tutoring. Here she met Evelyn Polson (later Page), who became a lifelong friend, and Olivia Spencer Bower. She shared a studio in Cashel Street with a group of fellow students interested in innovative artistic styles and approaches. The orientation of the college was more formal and academic, but a teacher, Richard Wallwork and his wife Elizabeth, encouraged her. She formed friendships with the Acland family of Mount Peel sheep station and the Rhodes family of Meadowbank sheep station. These associations lasted throughout her life, and were of great importance. The Rhodes appear as the Lampreys in A surfeit of Lampreys (1941).

Marsh met Rees after returning to New Zealand from overseas in 1921. Rees had founded a theatre company that Marsh joined, which toured the country with Rees' comic play, The Mollusc. Performances were well received in the cities but treated with suspicion in smaller towns, where the 
view prevailed that 'This Company can't be any good or it wouldn't come here!' (Swarbrick, [on Rees] DNZB website: 2007). After five months Rees was no longer able to pay salaries and, deeply in debt, she abandoned the enterprise. Marsh later described it as 'one of the earliest attempts to found a permanent theatre in this country' (Marsh, 1966: 156).

During this time Marsh was writing articles, poems and stories which were published in the Christchurch Sun. She wrote a play, The Medallion, which she later regarded as poor though promising. Academic Jane Stafford's DNZB entry on Marsh states that she saw herself as a painter, and in 1927 was included in an exhibition by The Group, organised to differ from the conservative hanging policy of the Canterbury College School of Art. Although she continued to paint, Marsh gave up serious aspirations. She

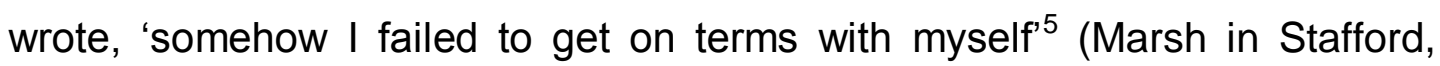
DNZB website: 2007).

In 1928 Marsh travelled to England. Her journey was recorded under her pseudonym 'A New Canterbury Pilgrim', in a series of articles that appeared in the Christchurch Press and were syndicated to other newspapers. On her arrival she stayed with the Rhodes family in Buckinghamshire and London. With Nellie Rhodes she established an interior decorating shop called Touch and Go, in Knightsbridge. She returned to New Zealand in 1932 when her mother became ill.

Before Marsh left Britain she had completed the draft of a detective novel, A Man Lay Dead, which she gave to Agatha Christie's literary agent, Edmund Cork of the Hughes Massie agency. He placed it with the publisher Geoffrey Bles, and it came out in 1934. Between 1934 and 1982 Marsh wrote 32 detective stories, shifting to publisher William Collins in 1938, with American publication by Little Brown from 1940. At a time when the detective genre was in the ascendant and predominantly its most admired exponents were women, Marsh became an acknowledged star along with writers Agatha Christie, Margery Allingham and Dorothy Sayers.

Marsh worked within the classic detective story form, enlivening it with the high quality of her writing and a range of erudite references. While many of her novels have an English village or country house setting and subscribe 
to a conservative view of society, she is capable of innovation, especially in terms of realistic characterisation and psychology. Several works use theatre as a narrative context. Four have New Zealand settings - Vintage murder (1937), Colour scheme (1943), Died in the wool (1944) and Photo-finish (1980) - and there are many New Zealand references and characters. Marsh in her long career also wrote works of short fiction as well as some nonfiction and some monographs, articles and essays. She also wrote for theatre, television and radio. ${ }^{6}$ Her success as a writer and the financial rewards it brought enabled her to indulge in a taste for expensive designer clothes, often of a strikingly dramatic style. Her theatre directing style was imaginative, meticulous and autocratic, based on her admiration for the theatrical style of London and Stratford.

Despite the amateur status of her actors, the results were highly acclaimed. But she was less sympathetic to any sense of an emergent nationalist culture in her own country, and particularly disliked the New Zealand accent, which she discouraged. This in turn may have lead to a kind of backlash, and she never felt she was recognised as an author in New Zealand. One biographer, Margaret Lewis, pointed out 'The truth is her fiction was admired everywhere in the world except New Zealand' (Lewis in Steeds, 1995: no pagination). Lewis commented that Marsh had to keep her more glamorous side concealed because of a New Zealand snobbery about crime fiction. However, critics point to Ngaio Marsh as the first crime writer to bring a novelist's sense of literary style to the genre.

She elevated the crime novel to a 'high level of literary art', a New York Times review pronounced in 1943 (Steeds, 1995). In her autobiography Marsh describes how she began writing detective books in London, on a rainy London day:

I read a detective novel from a little lending library in Bourne Street. I don't remember the author now, but think perhaps it was Agatha Christie. I was not a heavy reader in the genre but I had, on and off, turned an idea for a crime story over in my mind. It had seemed to me a highly original idea (Marsh, 1966: 216). 
Marsh's earlier attempt at a 'New Zealand novel I had laid aside. It was now abandonded for good. I cannot remember what I did with the manuscript' (Marsh, 1966: 217), and it seems she began her writing career in the crime story genre almost by accident. She felt that she was never accepted as a real novelist because she wrote detective novels. She was made an OBE in 1948, and a DBE in 1966. She never married, and died on 18 February 1982 at her home in Valley Road. ${ }^{7}$

\section{Dorothy Quentin: 1911-1983}

Madeleine Murat used 'Dorothy Quentin' as one of her pseudonyms. Others were Martin Tree, Linda Beverly and David King. She was to become a financially successful light romantic novelist, publishing seventy-two books. Little is known of her personal life except that she lived in the UK, Tahiti, and New Zealand (Auckland and Thames) and travelled extensively throughout the world. A note found in the Weekly News in 1938 stated:

Mrs John Batten, whose pen-name is Martin Tree, returned to New Zealand by the Tainui this week. She left the Dominion last November on a flying visit to England. Mrs Batten, who is a cousin to Sir Edward Jerningham, expects to leave New Zealand again, this time to America, where she will accompany her husband to Hollywood (Weekly News 9 March 1938: 27).

There are some references to Madeleine Murat in lan Mackersey's biography of Jean Batten, Jean Batten: The Garbo of the Skies, as she was married to the famous aviator's brother, John Batten. Mackersey wrote that John Batten had 'now married the writer Madeleine Murat, and they had a baby daughter Penny, born in August 1933, who, because of the family rift, was never to meet her aunt Jean' (Mackersey, 1990: 111). By 1936 the ostracised young family had obviously had enough, and John and Madeleine, 'with their threeyear-old daughter Penny, had gone to live in Tahiti where Madeleine continued to write' (Mackersey, 1990: 227). 
Dorothy Quentin wrote articles for publications other than her own prolific fiction output and the 1948 Author's \& Writer's Who's Who entry describes her as a 'scenarist'. While her earlier articles and stories remain untraced in Film Weekly (from 1932), in the English women's magazines Woman's Weekly, Woman's Own, Good Housekeeping and Cosmopolitan, and in the Australian Women's Weekly, there is one article that appeared in the English paper The Mirror (Quentin April 1941: 22) 'What's it really like in London now?' describing life in the English capital during the Blitz. A note with the article says that the author 'returned to New Zealand last February'. Later that year Quentin wrote an article for The Mirror that posed the question 'Are war babies wise?' (Quentin July 1941: 44). She answers her own question by advising: 'no, postpone them till the war's end'.

Prior to the war she wrote a regular feature 'Almost in Confidence' in The Mirror from June 1938 to December 1939 (and in January 1940 as 'The Round Table') offering advice to readers. The paper introduced Quentin as a married woman, a mother, widely travelled, and someone who has had long experience in dealing with personal problems. These features were often a full page with a chatty note by her on current topics. Later she began to contribute serialised stories to the paper, and a note in 14 Dec.1943 issue of The Mirror, with photo, describes Quentin as 'a newcomer among Mirror serialists, but an excellent storyteller with a following of millions in Britain and U.S.A. ${ }^{8}$

Despite her 'following of millions' Quentin gets only a brief, disparaging mention in the Oxford Companion to New Zealand Literature which says her 'romances often read like celebrations of the arrival of American consumerism in the 1950s' (Sturm, OHNZL, 1998: 470). While this may seem somewhat out of fashion, one can imagine many New Zealand women embracing aspects of 'American consumerism' after the many years of deprivation during the depression and war years of the previous decades.

Quentin fares a little better in The Oxford History of New Zealand Literature in English. In the chapter on 'Popular Fiction' a page and a half is dedicated to her writing and she gets her own entry in the bibliography section. Sturm writes: 'She was also New Zealand's first author to specialize 
in hospital romance' (Sturm, OHNZL, 1998: 604). He discusses her novel Rainbow Valley (1960), arguing: 'If the plot is flimsy, the celebration of New Zealand is not'. Here Sturm is interested in the eulogizing of American culture by Quentin as he was in the 'Companion'. He quotes Quentin that Auckland is like 'one of those old mediaeval tapestries, full of clear soft colours' ... Queen Street has huge shop windows ... 'bright with beach wear and model frocks and men's sports' wear that shouted of America. Many of the gleaming big cars were American, too' (Quentin in Sturm, OHNZL, 1998: 604).

\section{Dorothy Eden 1912-1982 ${ }^{9}$}

Dorothy Enid Eden was born in North Canterbury, on April 3rd 1912, the fourth child of six of John, a mail carrier (earlier a factory hand) and Eva Natalie Eden. Her paternal grandparents were from Gloucestershire and, on her mother's side she was of Danish and Bohemian ancestry. In the introduction to the 1978 edition of The Vines of Yarrabee she tells of her mother's parents fleeing the Prussian invasion of Schleswig-Holstein in the 1860s and her father's parents losing all three children on the voyage from England,$^{10}$ the last as the ship entered Lyttelton Harbour; four more were born in New Zealand. In her infancy her father began farming in Wakanui, and she grew up on an isolated farm with her four sisters, Marjorie, Winifred, Isobel and Eileen, and a brother Allan, who wrote Islands of Despair, an account of his wartime experiences in the sub-Antarctic islands.

Her family was convinced that she should earn a salary with secure employment, and for a while she worked in a Christchurch office, starting work at sixteen as a typist and later as senior clerk for Ashburton lawyer Robert Kennedy. The early stories were published under the name Ena Eden, as she was known in the family. She wrote her first book at the age of twenty and sent several manuscripts to English publishers, one of which was lost at sea during the war, before her first book was published in 1940. She continued to write magazine stories until the late 1970s and several novels were serialised before publication. 
She travelled widely and in 1954 settled in London, working for a time in Harrods's bookshop before becoming a full-time writer. She lived for many years in a block of flats in Edwardes Square off Kensington High Street, that locale being transformed into 'Melbury Square' in her novel of that title. Her early books were gothic romances and thrillers and later she also wrote historical novels and family sagas, or 'dynastic novels' as she called them, with settings as diverse as England, New Zealand, China, Ireland, Denmark, Australia, America, and South Africa, with real historical settings such the Chinese Boxer Rebellion and personalties including the love affair in Ireland between Parnell and Kitty O'Shea, all carefully researched.

Eden always wrote by hand, on scraps of paper, during office working hours, during her lunch hour, in bed at night. Then she would type a rough manuscript. Many original hand-written drafts went to Boston University, which established a 'Dorothy Eden Collection' in 1966. By 1980 she was among the ten best-selling authors in the world. Her later books appeared in U.K. and U.S. editions, hardbacks and paperbacks, with Reader's Digest Condensed books, large print and Braille editions, and audio versions.

The bibliographical appendix ${ }^{11}$ illustrates the extent to which Dorothy Eden was so successful internationally. Her first foreign sale was to her ancestral Denmark, and translations followed into over twenty other languages. Several of her books were broadcast on radio and at least one, Crow Hollow, was filmed. Eden's stories appeared over a span of almost fifty years in magazines in several parts of the world (and not just in English) and even when the titles of the magazines are known finding copies to inspect is often difficult. In an interview in Woman's Choice (Feb.1956) she talks of writing 'a dozen stories a year', and many were published more than once. A note in The Mirror (July 1960) says that Eden has had her work published in most leading English magazines and in several Continental periodicals, and in one of her articles she is quoted as saying that even she herself had long ago lost count of the number of short stories published in magazines in every English-speaking country.

Eden would sometimes take a temporary position at a job; this provided a change from the hard work of writing thrillers, and 'gives her scope for fresh 
material. Last Christmas, for instance, she worked for a while in Harrods's book department where she sold the young Prince Charles westerns' (Eden in The Mirror, 1957: 3). Commenting on her career Eden said in an interview with Peter Isaac:

It seemed an awfully long time, she says now. One of her remaining ambitions is to have one of her thrillers turned into a film by Hitchcock ... Though there is a strong vein of romance running through Miss Eden's books there is a much more solid core of action ... In spite of her liking for relatively raw action Miss Eden has an intense dislike of ever 'putting a dirty thought in anyone's mind' ... Dorothy Eden, as she admits, writes for people wanting to 'escape, for people who want to dream' (Isaac, 1975: 12-13).

It is interesting to note that after her expression of interest in being filmed by Hitchcock that in an analysis of twenty four best-selling 'modern Gothic' or 'romantic suspense' novels published 1950-1974, focusing on the interrelationships between the male and female characters in terms of their sex-role characterization and the attitudes and behaviour of the hero towards the heroine and the supporting female actor, that Eden is one of the authors analysed. (Weston \& Ruggiero, 1978: 647-55) Terry Sturm wrote:

Gothically tinged mystery and suspense, expertly contrived and resolved, were Eden's trademark ... and in later novels she increasingly drew on the Gothic potential of fairy tales, myths and legends (Sturm, 1998: 158).

Eden returned to New Zealand on a long visit in 1960 at the time of the publication of her New Zealand set novel Sleep in the Woods. Never married, she died of cancer on March 4th 1982 and was buried in London. Obituaries appeared in newspapers worldwide. Despite her popularity Eden, like Marsh, has never been regarded as a serious and important writer, although Sturm's writing on her in the OHNZL could be seen as an acknowledgement of her place in New Zealand literature. 


\section{Janet Paterson Frame: 1924-2004}

Patrick Evans writes:

The overwhelming sense, as we responded to her death, at the age of 79 on the morning of 29 January 2004, was of a personal loss as with a family member, someone who had lived deep within the warp and weft of our daily lives (Evans, 2004: 15).

In my case this was almost true as Janet's niece, Pamela Gordon, attests, both of us belonging to an extended 'Seacliff' family known as the 'Seacliff Mafia.' ${ }^{12}$ Evans states that he had long been used to his students' insistence, over the years, on referring to her as 'Janet'. He continues:

in the days after her death I listened to expressions of similar intimacy mingled with the bewilderment of people who clearly did not yet know how to weigh up what they had lost or how they would come to terms with it (Evans, 2004: 15).

Janet Frame was born into a poor Otago family in which there was much personal tragedy and difficulty. Her father worked on the railway and early experiences of poverty and premature death shaped her inner life. The life and work of Frame are well known through her auto-biographical writing and subsequent film by Jane Campion, An Angel at My Table, and Michael King's biography Wrestling with the Angel, as well as the fact that most of her novels are often assumed to be semi-autobiographical with recognisable friends and family members as the characters. As Evans suggests:

I began to sense many years ago, when I first sat down and read, in order, everything that she had written: not only that 'the autobiographical' had an unusually intimate relationship to her fiction, but that the two were interchangeable, that, generally speaking, the fiction is where the life is and the life is where the fiction is (Evans, 2004: 15).

This proposition was further confirmed when first Karl Stead and then Frank Sargeson, people who had befriended Frame in Auckland after she left hospital in 1954, also found themselves in print, the former as a young poet 
in 'The Triumph of Poetry' who sells out to academic life and goes bald, the other as the elderly gay writer in the novel Daughter Buffalo (1972). 'It is part of her ... slant on things,' Sargeson complained in a letter to Philip Wilson, 'to collect items about people she knows which she apparently has no second thoughts about using ... it's a sheer bastard when she involves a third party' (Sargeson in King 2000: 377).

But what is interesting about Sargeson, when he 'becomes' Turnlung in Daughter Buffalo, is the way Frame seems to give him, with very little sense of artistic transformation, the deaths of her own two sisters as the deaths of his:

as when she slipped her unwanted brother or her over-attentive Irishman into novels, it is as if she felt able to deal with painful or unpleasant realities through the convention that things in fiction never really happened (Evans, 2004: 15).

What is probably less well known is the number of works published by Frame and about her. My bibliography illustrates the extent of material available by and about her both in New Zealand and overseas. ${ }^{13}$ In fact, it is interesting and revealing in the context of this thesis that all the New Zealand women writers in this chapter are, as I have previously stated, rather more well known overseas than in New Zealand, as are some of the poets, for example, Eileen Duggan.

Tara Hawes, in a paper, 'Janet Frame: The Self as Other/Othering the Self', asks 'Why did Janet Frame pretend to be 'of Pacific Island origin' when submitting poems to the London Magazine from New Zealand? Later, when she went to England, why did she write from the point of view of 'a West Indian arrival?' (Hawes, 1995: v.1 n.1). The answer comes from Frame herself, and is an example of the playful seriousness of much of her work: 'I wrote a group of poems from the point of view of a West Indian new arrival [in England] and, repeating the experiment that Frank Sargeson and I had made with the London Magazine when I pretended to be of Pacific Island origin' (Frame, 1991: 308). Hawes writes: 
Frame's literature contains many examples of othering the self/selfing the other, such as 'Jan Godfrey' (one of her earliest short stories), where the narrator takes an identity then deconstructs it in the process of the story. The exercise of writing an autobiography is essentially one of othering the self, Frame describing it as an exercise of legitimacy, or making [herself] a first person (Hawes quotes from an interview with Elizabeth Alley, 'In the Same Room', p 40, Hawes, 1995: v.1 n.1).

Firstly then, who is Janet Frame? And who could not be forgiven for thinking that the character, Grace Cleave, in Frame's posthumously published first novel, Towards Another Summer, is none other than the author herself, freshly arrived in London for the first time, for example:

When she came to this country her body had stopped growing, her bones had accepted enough Antipodean deposit to last until her death, her hair that once flamed ginger in the southern sun was fading and dust-coloured in the new hemisphere, and she was thirty, unmarried except for a few adulterous months with an American writer (self-styled) who woke in the morning, said - I write best on an empty stomach, pulled out a piece of paper from his tweed coat hanging on the end of the double bed, and wrote one line. One line every day. She too was a writer, self-styled (Frame, 2007: 11).

Who can this be but the author, and yet ... ? The self-deprecating humour is always there, just below the radar, and gives Frame her distinctive New Zealand quality.

Hilary Mantel writes in an introduction to the latest edition of Frame's 1961 novel, Faces in the Water, that:

Even more than Virginia Woolf, Janet Frame is the prisoner of her biography; or, to be specific, of the eight years in her life when she was stigmatised as mad, and held in psychiatric hospitals (Mantel in Frame, 2009: vii).

But Frame had already countered what she probably guessed would be said of the book when it was first published. Her disclaimer of autobiography was written in the front of the original edition of Faces in the Water and again reprinted in the new edition: 'Although this book is written in documentary form it is a work of fiction. None of the characters, including Istina Mavet, portrays a living person' (Frame, 2009: dedication page). 
Frame is one of New Zealand's most successful writers. She wrote twelve novels, three volumes of autobiography, five volumes of short stories, two collections of poems, and numerous other short stories and poems published separately. She has also published a work of children's fiction, Mona Minim and the Smell of the Sun, and various reviews and critical essays. Mantel commented on Frame's capacity for hard work, stating this debunks the notion of Frame's madness. Mantel makes the point that:

A life so creative, diligent and self-directed suggests not damage or dereliction, but grip and focus beyond the powers of many who have spent a lifetime without their sanity being examined or questioned ... it is a source of exasperation to authors that their work is too often taken autobiographically, and that readers and literary journalists are obsessed with tracking down the 'real-life' places or people behind fiction ... Frame said that in Faces in the Water she had softened the truth; she feared that otherwise she would not have been believed (Mantel in Frame, 2009: viii, ix).

The respect in which Frame is held and her popularity as an author is reflected in the many honours and fellowships she has received, including Honourary Doctorates of Literature from the Universities of Otago and Waikato, a C.B.E., and the Turnovsky Prize for Outstanding Achievement in the Arts. In 1990 Frame was awarded New Zealand's highest civil honour when she was made a Member of the Order of New Zealand, and in 2003 she was an inaugural recipient of a Prime Minister's Award for Literary Achievement. Despite all these accolades and awards her work is often hard to find on bookshop shelves outside the main centres in New Zealand. This, according to Frame's literary executor Pamela Gordon, is despite all her novels having been reprinted. ${ }^{14}$ Frame died in Dunedin in January 2004.

In highlighting the writing and publishing careers of the five women I have written about in this chapter and the bibliographical material provided as appendices, I make the point that women novelists were neither inconsequential nor insubstantial in the annals of New Zealand literature of the period between the end of WW2 and 1970. As illustrated by their bibliographical notes in the appendices to this thesis their publications overseas in English and in translations add up to a significant body of work. There is scope for further research covering this subject. While this thesis is 
designed to bring notice to such observations on the period 1945-1970 it is outside the scope of this work to give detailed analysis.

However, the women writers presented here appear to have been marginalised and trivialised by much literary criticism of the time. It has only been since publication in the 1990s of Sturm's Oxford History of New Zealand Literature in English and Robinson and Wattie's Companion to New Zealand Literature that many of these women writers have been acknowledged.

The exception is Frame. She was, however, often seen as an adjunct to Frank Sargeson, and not a threat to male literary dominance because she could be dismissed as being 'mad'. This was the case even up to the later years of her life. For example, when Liverpool writer Linda Grant was asked by Frame's biographer Michael King if she would like to meet Frame during a visit to Dunedin she answered that she would, being an admirer of Frame's work. King, however, warned her of Frame's sensitivity and often reclusive behaviour. Grant wrote:

After forty-five minutes, as instructed [by King], I rose to leave. The next day I flew back to Auckland and ran into a certain level of resentment, that I, a British writer on my first visit to the country, had met New Zealand's greatest living novelist when she was widely believed to be reclusive and a bit mad. She was neither. She simply wanted to get on with writing (Grant, 2009: xvii).

Summing up this chapter on women novelists it is important to note that the majority were far more successful, financially and critically, overseas than in New Zealand and most of them were single. The next chapter discusses three literary and artistic marriages and how the women coped with family life in relation to their literary and artistic ambitions. I include a woman who was a single parent during the period as a point of contrast with the married women.

\footnotetext{
${ }^{1}$ Included as an appendix is a bibliography of each of these five writers, to illustrate the extent that women writers were prominent in certain genres of the literature of New Zealand during the early and middle decades of the Twentieth Century.
} 
${ }^{2}$ I have noticed this myself over the years when I worked on the Railways and as a drain-layer: I have met other men who were far more well read than university people that I knew, perhaps because academics often restrict their interests to particular fields of knowledge.

${ }^{3}$ Again I can attest to the reality of this feeling in the work I have done on the Railway track gang and laying sewer pipes etc. While most of these male writers did not experience these things themselves the authenticity of their writing about it is nonetheless true as they probably picked up the stories they wrote of in hotel conversations where they got their experience as "real men".

${ }^{4}$ See appendix 1 Rosemary Rees.

${ }^{5}$ This is an interesting quote by Marsh concerning herself and may be significant in the chapter on lesbian writers.

${ }^{6}$ See bibliography (b) Ngaio Marsh 1895-1982 Appendix 2.

${ }^{7}$ There is further discussion on the life of Ngaio Marsh in the chapter of this thesis regarding lesbian writing.

${ }^{8}$ My mother was one of those 'millions' who read the romance books by the women writers of the 1950s and 1960s. In fact, they were the only form of literature in our house if you discount my war comics and dad's 'naughty' magazines, a scene played out in households throughout the country at that time, no doubt.

${ }^{9}$ Some of the biographical and bibliographical information on Dorothy Eden was given to me by the Wellington private scholar and bibliographer Rowan Gibbs, to whom I owe thanks.

${ }^{10}$ New trade edition, 1978, 0698109422, as part of the publisher's fiftieth anniversary commemoration: [ ... ] YARRABEE | [publisher's device: altered device now including 'Geoghegan' and including figure 50 between years 1928 1978] | COWARD, McCANN \& GEOGHEGAN, INC. | NEW YORK

[i-iv]v-vii[viii][7]8-381[1]pp.: p.[i] half-title; p.[ii] 'by Dorothy Eden [15 titles]; p.[iii] titlepage; p.[iv] "Acknowledgments [as in 1969 edition] | First American Edition 1969 | Copyright (C) 1969 by Dorothy Eden | Introduction (C) 1978 by Dorothy Eden [ ... ] | Library of Congress Cataloging in Publication Data [ ... ] 78-6654 | ISBN 0-69810942-2 | Printed in the United States of America"; pp.v-vii "Author's Introduction"; p.[viii] blank; pp.[7][sic]-9 "Prologue"; p.[10] blank; pp.[11]-381 text; p.[382] blank (apart from prelims, same setting of text as 1969 edition); red cloth with gold facsimile of author's signature near foot of front board; red and yellow headband; $220 \mathrm{~mm}$; dust jacket as on 1969 edition but price " $\$ 10.95$ " at top of front flap, code 7808 and "SBN: 698-10942-2" at foot, and 50-year device added on lower flap. The added introduction, signed "Kensington, London, March 1978", stresses the hardships faced by the early European settlers in Australia and discusses the reasons for her own grandparents' emigration to New Zealand; she thanks "her publisher, friend and mentor, Jack Geoghegan, who has nurtured my career with such great success since buying my first book [the first published in U.S.A.], Sleep in the Woods, when I was an unknown writer, and slowly but surely building on to that modest cornerstone. Jack was privately worried about The Vines of Yarrabee. He thought the setting would have little interest for Americans. Indeed, he devised a jacket that was more like Kentucky, or even Texas, than the solitary Australian 
plains $[\ldots$. $]$ however, the book was a triumphant success $[. .$.$] I was in the bestseller$ lists for three months, and Australia was on the map...". (Reference as in Endnote \#9).

${ }^{11}$ See appendix number 4.

12 Pamela Gordon, Janet Frame's niece, and now her literary executor, wrote an anecdote about me for The Earl is in ... a book celebrating 25 years of the Earl of Seacliff Art Workshop (2009). Gordon says: 'But the jewel in the crown concerns the time in the 1990s when we were both living in Seacliff Village and we used to flag the Dunedin-bound Southerner down at the Kilgour Street Crossing and ride that last exhilarating section of seaside track into the city. One day I had a secret rendezvous planned; my aunt Janet Frame was travelling south from Christchurch and I had arranged to meet her on the train at Seacliff and travel through to Dunedin with her. It was my habit to protect Janet's privacy so I didn't tell Michael [O'Leary] she'd be on the train, but I was delighted when he decided to join me on the journey, just for the hell of it, because it would give me an opportunity to introduce two of my good friends. So here's the story: we got on the train, and when Michael met Janet, he shook her hand and said: "I'm the Earl of Seacliff." She smiled graciously, and said, "And I'm the Queen of Seacliff."'

\section{${ }^{13}$ See Appendix 7.}

${ }^{14}$ Spotted this staff recommendation at the big Auckland City Whitcoulls branch on the corner of Queen and Victoria Streets: "Janet Frame is one of our most incredible writers. Her works are intense \& emotive. A joy to discover".

I'm often asked by visitors to New Zealand why it seems to be so hard to buy Janet Frame's books here in the very country that produced such a great writer on the world stage? It's a good question ... (Gordon, 2009: website). 


\section{Chapter 7}

\section{Three Marriages and a Single Parent}

Some individual examples of marriages of literary women of the period illustrate the issues discussed earlier and show the impact of matrimony on their lives, personal and literary. How did the women in these marriages find time to write as well as doing the work involved in being a wife and mother? In previous chapters I have alluded to the issues of marriage and motherhood, in, for example, the individual case studies of writers in the chapters on women poets and women novelists.

But in this chapter, I specifically analyze three marriages involving couples where both the man and the woman are writers or artists to describe their roles within and without the home. The men are among three of New Zealand's most famous and acclaimed writers and artists - Colin McCahon, ${ }^{1}$ James K. Baxter and Alistair Te Ariki Campbell. These three men were married to three talented and independent-minded women: the artist Anne McCahon, poet J.C Sturm ${ }^{2}$ (Jacqui Baxter), and poet Meg Campbell respectively.

At the end of the chapter I discuss a poet, Karen Peterson Butterworth, whose individual struggle to become a writer in a solo parent situation contrasts with that of the women of famous male partners. While her individual story takes up the same number of pages as the three marriages together it is important because it covers issues relating to women who attempted to lead independent lives at the time. The fact that Butterworth was not published until many years later proves the point of how difficult it was to become a writer for a woman at that time.

\section{Anne and Colin McCahon}

In Between the lives: partners in art, a book published in 2005 and edited by Deborah Shepard documenting the marriages and relationships of couples who were prominent in the world of New Zealand arts and literature, Linda 
Tyler's contribution is titled 'I did not want to be Mrs Colin'. Anne Hamblett was destined to become what she least wanted to be, that is, known as the wife of New Zealand's most famous and respected artist, Colin McCahon.

In their early years both McCahons played a large part in the artistic fabric of New Zealand, forming long-term friendships with other artists. In a poem by Colin McCahon (2001) written at Titirangi after the McCahons moved from Christchurch he watches his wife Anne and their friend Rita Angus:

Anne \& Rita read each other well, Close - so far apart,

The air between so calm \& clear

With grace and love

Rita going north,

Northland,

Kauri

(McCahon, 2001: 4).

According to Dunedin set-designer Rodney Kennedy, Anne McCahon was 'the best artist of her generation' (Kennedy in Shepard, 2005: 31) to which Tyler adds that Anne seemed destined to be an artist when she met McCahon, and early in her career Tyler states 'In 1937, however, it was Anne who was the leading Modernist' (Tyler in Shepard, 2005: 34). Tyler writes:

However, the demands of marriage, motherhood and making-do on a scanty income from art sales supplemented by poorly paid jobs seem to have exhausted Anne's creativity. While her husband never doubted that he had a contribution to make as a painter, and found supporters for his work, Anne could not sustain her own art-making and recognised eventually that there was room for only one artist in the family. When their son William said in an interview with Agnes Wood ${ }^{3}$ in 1992, 'Colin overcame his only real artistic rival by marrying her', he was articulating a situation familiar to many artistic couples where the male artistic [and or literary] genius was dominant and the needs of a creative supportive partner subordinate (Tyler in Shepard, 2005: 31-32).

Gregory O'Brien in his 2007 history of the New Zealand School Journal writes: 
Anne McCahon contributed to the Journal regularly over the next eight years [from 1953], producing over fifty illustrations in 1955 alone. With their heavy outlines, the drawings have an affinity with Colin McCahon's early figurative paintings, hinting at a common interest in folk and religious art. Anne McCahon's drawings are impressive for their economy of means, and also - something in short supply amongst New Zealand illustrators at this time - their sense of humour ... While Anne McCahon's career as an exhibiting artist effectively ended in 1945, her drawings are a highlight of the 1950s School Journal and a significant achievement on their own terms (O'Brien, 2007: 119).

Thus we can see the constraints on an acknowledged talented woman artist were such that her own career was literally 'set aside' by family, social and economic constraints and concerns in favour of her husband's artistic advancement.

\section{J.C. Sturm and James K. Baxter}

I was a personal friend of both short story writer and poet Jacqui Sturm and poet James K. Baxter, and publisher of Sturm (2002). Theirs was another artistic/iterary marriage. Also into this mix of male and female came the added ingredient of their marriage being a bi-cultural one, Māori and Pākehā. While I explore Sturm's career further in Chapter 8 on Māori women writers, it is interesting to note here the successes and ground-breaking aspects of some of her earlier work. Not only was she 'probably the first Māori woman to obtain a university degree when she completed her B.A.' (OHNZL, 1998: 517 ) in 1949, she also was the first Mãori writer, male or female, to have a short story published in English in Te Ao Hou, in 1954. Throughout the 1940s she had work published in student newspapers and in the 1950s further work appeared in $\mathrm{Te}$ Ao Hou as well as the literary magazine numbers.

Paul Millar and Aorewa McLeod (1998) state that Sturm's stories:

are succinct and lucid and on first reading they appear to embrace the era's dominant ethos - that New Zealanders were one nation - by avoiding specific reference to Māori. However, read against the grain of thought that expected, in Sturm's words, all Māori 'to become respectable middle-class citizens, a lighter shade of brown, as it were', it 
becomes clear that the society she depicts fosters inequality, and her work conveys a strong and poignant sense of alienation. Her female narrators, although rarely defined by their race, are marginalized figures that give a vivid sense of the constriction and restrictions of a young woman's life in Wellington in the 1950's (Millar and McLeod, 1998: 518).

In $1948 \mathrm{Jim}$ and Jacqui Baxter (J.C. Sturm) were married and among the many ironies of their life together three points relating to her writing career stand out. Paul Millar writes:

When her relationship with Jim was commented on, it was almost never acknowledged that she was a writer also. In fact she had begun writing well before she met him, and she has continued writing well after his death (Millar in Shepard, 2005: 140).

Another irony is that she stopped writing poetry soon after they met. In an interview with Millar she confesses that while many people saw Baxter as a drunkard and womaniser:

Well - he was - But poetry and writing and the whole creative process was what really had captured his life. And as I saw how serious this man was about writing I thought what am I doing, I'm just puddling around. So I stopped (Millar in Shepard, 2005: 147).

In the early 1950s, when Sturm had shifted from writing poetry to writing short stories, they reached a stage where Millar says writing became a companionable adult activity. He quotes Sturm:

Jim was very supportive of my writing, which was usually done after nine o'clock when the kids were in bed and the nappies were washed (Sturm in Shepard, 2005: 149).

However, by the mid-1950s Baxter's drinking was becoming a real problem for his wife and family. This is reflected in her stories written during this period, but not published until 1983 as The House of the Talking cat ${ }^{4}$. Lydia Wevers writes:

They are narratives of women alone [as opposed to 'man alone'], caring for children, working, and tied to husbands who come home late, drunk 
unable to offer comfort or protection from the threatening world outside the home. (Wevers, 1998: 284).

Baxter's drinking and his attempts to stop gave rise to a further irony of their marriage. His solution was to seek help by joining Alcoholics Anonymous. But, Millar writes:

his new commitment to AA left Jacqui feeling abandoned. Exactly how far apart they had grown became evident when he, without warning, converted to Roman Catholicism. Jacqui was stunned to discover that he could have pursued such an important spiritual path without telling her. The trust that had been shaky for some time evaporated completely. In October 1957 they separated for the first time, a decision Jacqui still regretted four decades later (Millar in Shepard, 2005: 152).

Sturm has her own take on events in her poem 'Twenty-five years later':

In the middle years, he patched his coat with signs and symbols I understood only dimly, Chose not to wear too. We should not have let them separate us as they did (Sturm, 2000: 62).

Baxter left home, leaving Sturm with the children and she began working part-time to make ends meet.

Baxter had been a School Publications editor between 1956 and 1963 and in the late 1950s he won a Fellowship from UNESCO to study educational publishing in India and Japan. During this trip the family went with him and the couple got back together again. As Sturm states: 'that's where we remarried I suppose you could say. And the children regained their father and family life' (Sturm in Shepard, 2005: 154). The period through the early and mid-1960s was a stable time for the family, emotionally and financially. But after two years as Burns Fellow Baxter was again feeling stuck. Millar writes: 
He struggled in his marriage, fearing the trap of domesticity; found difficulty relating to his maturing children; and was dogged by the feeling that words had become impotent and should be replaced by actions (Millar in Shepard, 2005: 155).

By the end of 1968 the Baxter family were back in Wellington, but in December of that year Baxter had left to follow his Jerusalem 'vision'. And it was this stage of their marriage that presented perhaps the greatest irony of Sturm's life in relation to Baxter. Millar suggests that the irony lies in the fact that in his final years:

he came to represent Māoritanga more strongly than Jacqui. His writing records such things as his attempts to learn Māori, the establishment of his tribe of nga mōkai (the fatherless ones) at Hiruharama, and his thoughts on biculturalism. It is an honest record, yet it has obscured the Māori heart at the centre of the Baxter household that had been beating strongly since the 1950s when Jacqui joined Ngāti Poneke and the Māori Women's Welfare League: 'I became pretty involved with the concert party. I went to hui, Māori competitions. And l'd take the children. The children joined ... Jim would come when he could. He'd always sit there very quietly. He was nervous of the whole situation as he hadn't had any experience of it' (Millar and Sturm in Shepard, 2005: 155,156).

In 1969 Baxter was living away from the family and Sturm had effectively become a solo mother again by taking on the task of bringing up her granddaughter. She also became a librarian to earn a living to feed her new family as Baxter had become anti-establishment and anti-materialistic with his new-found philosophy. In Dedications (1996) Sturm reflects on Baxter's abandonment of her and their family. In the poem 'Grieving, 1972: for Jim' deals with the feelings his actions provoked in her. This is the cry of many women expressing the anger and the grief at being abandoned, either through the breakdown of a marriage or by death of the husband, and in this case both. However, in Dedications Sturm also shows how even after so many years and another marriage she still loves him and needs his reassurance. In 'Urgently: for Jim' Sturm writes:

And bring me safe

To that bright place 
(I believe -

I swear I believe)

Where we may be together

Again, forever

(Sturm, 1996: 81).

Sturm's poem also seems to be an answer to Baxter's own poem to her, written in the early 1970s. 'He Waiata mo Te Kare' is a moving and complex poem written to his wife while he was living at Jerusalem, detailing and reflecting on their relationship. In part eight Baxter compares their marriage against the wider aspects of social and personal life.

I was a gloomy drunk,

You were a troubled woman,

Nobody would have given tuppence for our chances,

Yet our love did not turn to hate.

I never wanted another wife

(Baxter, 1974: 3-4).

\section{Meg and Alistair Campbell}

I was a personal friend and publisher of Alistair Te Ariki Campbell and Meg Campbell, another example of literary marriage between two poets. Formerly, Campbell was married to the poet Fleur Adcock, a marriage that did not last. Adcock moved to England where she has received considerable recognition as a poet. While the lives and circumstances of Meg and Alistair Campbell were very different to the Baxters' married life it is interesting to note some similarities in the underlying psychological and spiritual aspects, as written in their poetry to each other, along the lines of Baxter and Sturm. Although the Campbells remained together there were frequent forays by Alistair into other relationships, which he always felt remorse over, but somehow couldn't stop becoming involved in. An expression of this aspect of their lives together is found in a poem from his collection The Dark Lord of Savaiki:

O love, knowing your constancy,

how did I fail 
to lean it against your heart?

(A. Campbell, 2005: 89).

Like Baxter's poem it addresses a problem within the relationship and expressed the wish that things could be different. 'I never wanted another wife' says Baxter, although he had effectively left Sturm, and certainly had other women in his life, which is also the case with Alistair in his poem about owning up to an affair. Meg, on the other hand, remains focussed on the fact that despite everything they have remained together. In her poem 'On a Plate: March 2001' she writes about him when he is overseas:

Our cruelties wear us out, but still

we remain together.

Do you understand?

(M. Campbell, 2005: 37).

'Overlooked and judged unfairly' can be an estimation of Meg's work and life as an 'outside' expression as much as the 'inside' expression found in her own poem. Poet and academic Siobhan Harvey in a recent review of the Campbell's joint 2008 book of poems, It's Love, Isn't It? writes that:

If, in her lifetime, Meg Campbell's poetic gifts were often overlooked, It's Love, Isn't It? helps to redress such neglect. Her verse in the book, ably underpinned by a fine introduction from Joy Mackenzie, showcases her as the literary equal of her much-honoured husband ... [her] talent for concision, imagery and expressive language (Harvey, 2009: 107).

Joy Mackenzie, in the introduction to the Campbells' book, writes of the 'likeable personality' behind Meg's poems. Mackenzie continues:

I admired the way she had survived many trials in her life: marital difficulties, post-natal depression, incarceration in Porirua Hospital, electric shock treatment, marriage to a publicly acclaimed writer, and the difficulties involved in being a second wife and step-mother (Mackenzie, 2008: 7).

Even one of the troubles above would have been enough to cause difficulties in a person's life, let alone a list such as Mackenzie enumerates. Whereas the Sturm-Baxter marriage, for instance, suffered from the changeable nature of their circumstances, financial and personal, the Campbells' 
situation was unstable in other ways, social and personal, in that Meg was not only seen as 'the woman who broke up a marriage' but that both Campbells suffered from mental illness. As a woman Meg was particularly sensitive to the different treatment meted out to her as a mental health patient. In her essay in Between the lives on the Campbells, Mackenzie quotes a 1994 letter she received from Meg. In it Meg writes:

\begin{abstract}
Alistair's experiences at Porirua Hospital were very different from mine. He was under the care of his good friend Frazer McDonald, and instructions were given not to give him shock treatment because it 'might affect his brain'. Being a well-known figure, I think that Frazer didn't want him tampered with ... it was different for me. I was given several courses, each involving 5X shocks (M. Campbell in Shepard, 2005: 198).
\end{abstract}

This social/sexual paradigm was prevalent in psychiatric thinking until very recent times. Mackenzie states that:

Peter Breggin, an American doctor who opposes the use of ECT, has noted that women more often receive electro-convulsive therapy than men because women 'are judged to have less need of their brains'. An investigation into the use of ECT in New Zealand hospitals showed that in 1978 the majority of patients given ECT were women; in one hospital, 75 percent of those receiving ECT were female patients (Mackenzie in Shepard, 2005: 198).

Mackenzie then postulates that Meg is part of a New Zealand literary canon based around women's treatment at the hands of generations of medical practitioners of psychology related illnesses, one of which appears illnesses to be being 'a woman'. Mackenzie states:

That more women than men endured periods of suffering as psychiatric patients reinforces the need for women writers' accounts of their experiences and treatment, and establishes links in the female tradition. In New Zealand, Janet Frame and Robin Hyde are important forbears (Mackenzie in Shepard, 2005: 198).

From the beginning of their marriage Meg felt she was either 'overlooked or judged unfairly', sometimes both at once. While their love for each other was 
undoubted, coupled with a shared love for literature, the Campbells' marriage quite quickly became problematic. Meg was guilt-ridden and remorseful about her part in Alistair's divorce from his first wife. She felt out of her depth among Alistair's seemingly sophisticated friends - artists, poets, novelists and editors - and she lost touch with her own friends.

Meg wrote her first poem 'Solitary Confinement' in 1969 while she was in the Female Refractory Ward, Villa 9, Porirua Hospital. By the time I published her book Resistance (2005) she had become an accomplished poet. We published 200 copies, the normal small press poetry print-run in New Zealand, which sold out within a short time and I had the feeling that had she been taken seriously as a poet earlier in her career she would be considered as one of New Zealand's best poets.

\section{Karen Peterson Butterworth}

In contrast to the trials and constraints of the married women above I now use the example of Karen Butterworth to illustrate some of the difficulties encountered by a solo mother in the 1960s whose ambition to become a writer was thwarted by her circumstances. I have published the poet Karen Peterson Butterworth ${ }^{5}$ in my ESAW mini-series (Butterworth, 2006). Butterworth was born on $7^{\text {th }}$ August 1934 in the Catlins, a backblocks district in South Otago. Her father was proud he had finished primary school and obtained his Proficiency Certificate. After he married he was a manual labourer. Her mother had attended high school for one year. Both of them were excellent storytellers. While her mother's chief talent was art, she had two stories and some light verse published in the New Zealand Listener, and was a profuse and interesting letter writer, as was her father.

When Butterworth was nine she caught poliomyelitis and was quadriplegic except for her left hand for three months, then gradually regained some strength. For most of the first five months, she could do nothing to pass the time except read. Her father's friends gave her a wooden 
bookstand to lean against the cradle that covered her legs so that her left hand could turn the pages if the nurses laid her arm beside the bookstand.

Next she started on the school's library books that contained mostly adult classics that had been donated. There were works by Dickens, the Brontés, Charles Reade, Sir Walter Scott, George Eliot, Thackeray, and Hardy. They had gathered dust for decades and her parents had to cut pages for her. Butterworth states:

I devoured them whole. I was puzzled by the stories of The Cloister and the Hearth, Tess of the D'Urbervilles, The Heart of Midlothian, and Adam Bede. My mother had told me that grownups did something that started babies that could only be done within marriage ... I was at a loss as to why Hetty killed her baby and Tess her lover, but concluded that murders must be common in Britain (Butterworth, 2010: unpublished).

Butterworth did secondary school studies by correspondence, and passed School Certificate. She wound down from her exam stress by writing an essay for a competition on the subject 'Our Way to Peace'. She reports:

I'd barely noticed that the prize was a trip to Britain representing New Zealand at the Third World Youth Forum, and my family and I were astonished when I received a telegram saying I was one of five finalists, and could I please come to Wellington for an interview? Mum and I travelled to Wellington by slow train, boat train express and Lyttelton ferry, a great adventure for me (Butterworth, 2010: unpublished).

During that year Butterworth's English teacher announced that an Otago woman writer had won a famous short story prize. Her name was Janet Frame. She bought copies of Frame's book for the class and they all read it. Butterworth reports:

It was a revelation to me that writing about everyday Otago life was legitimate - my reading until then had all been set in Britain or Europe. Only at 'varsity did I discover other New Zealand writers including Katherine Mansfield, Frank Sargeson, and Robin Hyde (Butterworth, 2010: unpublished). 
Butterworth thought the best way to obtain further training in writing was to do a four-year journalism cadetship. But the Vocational Guidance Officer said flatly, 'No. With your polio you couldn't carry a heavy typewriter about with you to assignments'. She turned down her next six career choices too, on the grounds they were too heavy physically (e.g. horticulture) or women didn't do them (law). She suggested library work, in which Butterworth had no interest. But she got a part-time job at the university library to pay for her studies and living costs and began to study part-time for her arts degree, majoring in English.

She saw an advertisement for a cadet at the Taranaki Daily News and answered it. She was successful, with three years taken off the cadetship for her English units, meaning she could qualify as a junior journalist after only one year. However, on her first day at work, the editor called her into his office and said something like: 'I don't hold with women reporters, but the Board forced my hand. You can't gather news in pubs, and I have to pay you a full wage'. The Journalists' Award was one of the few without a separate lower rate for women, who were so rare the negotiators never thought of them. However, respectable women couldn't go into public bars, where the best news was to be found. Butterworth explains:

I left his office fuming. Then I was called into the Chief Reporter's office. George Koea, who was later married to novelist Shonagh Koea, was my immediate boss. He said something like, 'Don't listen to that old fogey. It was my idea to hire you, and I look forward to our association.' At twenty-five he was the youngest Chief Reporter in the country, and one of the best. I promptly fell in love with him, but a relationship between boss and a worker of the opposite gender was unthinkable then. I'm sure he never thought of it (Butterworth, 2010: unpublished).

Also on the staff was Harry Dansey, cartoonist and Illustrations editor. He and George taught her a great deal about Māoritanga, of which as a South Islander she explains she was largely ignorant. The Taranaki Herald, the local evening paper, would not employ Māori. The Daily News was exceptional in Taranaki, where everyone, Māori and Pākehā alike, carried a load of historical racial grudges. Butterworth says that George Koea gave her wonderful basic training. 
He made Butterworth second-string drama critic, and frequently called her to his office for long chats on artistic subjects. However, she says that his close proximity and her hopeless love for him caused her so much agony that after a year, when she had qualified as a $\mathrm{J} 1$, she left to become a publicity officer in an overseas aid organization in Wellington. She was then on female wages from 1957 until 1967 when she joined the Public Service which by then had equal pay.

One day Butterworth climbed the stairs to the Teachers' College library, where by the late 1960s she was training to be a teacher, with an armful of books and fainted at the top. Before she was fully conscious the staff asked if she was pregnant and she said 'yes'. College rules at that time meant she had to leave immediately, but could apply for re-admission a year later. Her landlady heard and evicted her, and she was suddenly without an income or a place to stay. Her thoughts were at the time:

Here was rich material for writing, and in the absence of study obligations words began to flow in my evenings alone with my Smith Corona and a one-bar heater. I wrote a short story ('Johnny's Paalagi') and several anguished self-indulgent poems, none of which was ever published (Butterworth, 2010: unpublished).

No employer at the time would employ visibly pregnant single girls. By five months her pregnancy was showing and it seemed as if a home for unmarried mothers was Butterworth's only option. She could not go back to her parents, who lived in a small community and would never be allowed to forget her 'shame', especially considering that the child's father was a Samoan.

It was not easy and she was too busy and tired to write much for eighteen years. However, she drafted a novel about two single girls sharing a state house and bringing up their babies. It was to be a satire about overcoming government and teachers' college bureaucracies. Meanwhile she kept attending College though she found it difficult. She had been corresponding with a Māori man who had a dairy farm and wanted her to marry him. She states: 
he wrote poetry in Māori and English. He was of rangatira descent and had been educated at St Stephen's College ... I married [him] mainly to relieve my stress level. I soon realised my husband was mentally unwell ... he would show no-one his art or poetry, and having shown them to me became suspicious that I would reveal them to others. The end came soon after he claimed I was trying to poison him ... one day when I tried to get through to him, he responded by beating me up ... He said he was going to a hui, and I and the tamaiti must leave before he came home, as he didn't trust himself ... the kaumātua of his hapū were very supportive (Butterworth, 2010: unpublished).

She left her son with her parents (who passed him off as her stepson to avert gossip) for a few weeks while she arranged to go back to teaching and find accommodation. Butterworth found a Probationary Assistant's position in Lower Hutt and rented a bach in a couple's backyard.

At that time there were only widows' and deserted wives' benefits. Single mothers and divorcees obtained what they could through the courts, provided they could afford a lawyer. Single mothers were entitled to maintenance for their children only, while separated or divorced women could also sue for their own maintenance. A group organized a delegation to see a senior manager in the Department of Social Welfare, who told them there was a widows' and deserted wives' benefit, and there wasn't one for men, because research showed children were best off living with their mothers.

They soon had the chance to make submissions to a Royal Commission on Social Security. Butterworth wrote their submission and testified before the Commission. After Parliament had received the Commission's report it legislated for a number of reforms, among them the Domestic Purposes Benefit. She felt they shared the credit for this with the many church organisations who had testified similarly. She states:

Some people snubbed me for the 'shame' of my situation, which in their eyes was exacerbated by my child's racial mixture. (There were at that time also many people who stigmatised divorced and separated women) ... friends and relatives kept pestering me to give up my son for adoption and/or look for a husband. I responded by saying, 'one day, l'll get married'. This was exactly what happened when my son was eleven. The social support I received from my immediate family (by letter), the Society of Friends which I attended, and my fellow solo parents, kept me from sliding into depression (Butterworth, 2010: unpublished). 
Butterworth found a part-time editing job in the Department of Education. She began saving for a deposit on a state house. She remained in the basic grade for three years, with annual rises within its scale. During this time she also finished her degree part-time. In 1968 her job came under threat in a recession. Part-time workers could be sacked without notice, so she negotiated to work full-time and organized good child-care for her son.

Butterworth became active in the Public Service Association, serving successively on the Women's, the Part-time Work, and the Child Care subcommittees of its Executive Committee. If you wanted to move up a grade, you needed to apply for higher positions. She rose from Grade I to Grade XI but after failing six interviews, she suspected she was blacklisted for her union and political activities.

Not until the early 1990s was Butterworth at last able to write seriously. She has since published a book of her local newspaper columns and two poetry collections, edited or co-edited five non-fiction books and a haiku anthology, won prizes and been published in literary magazines and anthologies in seven countries including New Zealand. In Māori Language year she commenced seven years of part-time study of Te Reo Māori, two of them at Te Wananga o Raukawa, and wrote some poems in te reo, winning the Whitireia Poetry Competition Award.

In this chapter I have included all this detail in order to illustrate the dynamics in the lives of women who wanted to become writers and artists and the constraints and difficulties, personal, economic and societal that affected their careers. Both in statistical and individual instances I have provided evidence of the variety of reasons why women writers experienced constraints on their careers, whether these were family commitments, low self-esteem, lack of support from friends or society generally, the fact that their husband's careers took 'centre stage' even though that often underscored the instability which the marriages suffered because of their husband's often erratic employment, while Butterworth's story is an example of the struggle of a solo parent, both political and personal. 
In the following chapter on Māori women writers the discussion centres around what could be termed a 'non-existent' literary tradition if looked at from the literary norms at the time. Added to sex discrimination, the factors of race were an additional constraint in the New Zealand of the period. ${ }^{1}$ Although mainly known as an artist Colin McCahon wrote a considerable amount
of poetry also. In 2001 Peter Simpson edited a collection of poems by McCahon
dedicated to his fellow artist Rita Angus who was a friend of Colin and Anne. The
book was hand-set and printed by Brendan O'Brien while he stayed for a time at the
Rita Angus Cottage in Wellington, and was done in a limited edition of 175 copies to
coincide with the Rita Angus Exhibition held at Wellington City Gallery, July-August,
2001 .

${ }^{2}$ There is further discussion on the life and work of J.C. Sturm in Chapter 7 on Mäori women writers.

${ }^{3}$ From MS Papers AG 466, Agnes Wood Collection, Hocken Library Archives and Manuscripts.

${ }^{4}$ This collection was republished in 2003 by Steele Roberts, following the successful publications of two poetry collections by the same publisher: Dedications in 1996, and Postscripts in 2000. Each of these three volumes featured artwork by the Baxter's son, John Baxter.

${ }^{5}$ From: 'My Affair With Words' by Karen Peterson Butterworth. This account covers only those life events with a significant impact on her writing and the directions it has taken. Other chapters of her autobiography (still a work in progress) place them in the context of her life as a whole. This work was given to me for use in this thesis by Karen Peterson Butterworth, (c) January 2010. 


\section{Chapter 8}

\section{Māori Women Writers}

In this chapter I discuss the Māori women writers and their virtual nonexistence in the New Zealand literary world before the 1970s, when Patricia Grace of Ngāti Raukawa, Ngāti Toa and Te Āti Awa published her first work, Waiariki, said to be 'the first book of stories written by a Māori woman' (O'Brien, 2007: 71). Until the late 1960s and the early 1970s Mãori writers in New Zealand were scarcely mentioned in the annals of New Zealand's national literature. The names of Hone Tuwhare, Ngā Puhi, Witi Ihimaera, Te Aitanga-a-Māhaki, Ngāti Porou, and Rore Hapipi (Rowley Habib), Ngāti Tüwharetoa, are the more obvious male writers who began to be noticed. However, there were also Māori women writing during the 1940s to the 1970s period, none of whom appeared in the major poetry anthologies of the time.

\section{No Māori woman, no cry}

Neither Curnow's A Book of New Zealand Verse, (1945) nor An Anthology of New Zealand Verse (1956) edited by Robert Chapman and Bennett, included any Māori women poets. Some Māori women writing at the time may have been composers of waiata, powhiri, and other traditional forms of verbal expression, and although their works may not have reached beyond the Marae and the local tribal areas where they were written and performed during this period, they should have been acknowledged in these major anthologies as weavers of the word in Aotearoa New Zealand.

\section{Erihapeti Murchie}

One composer of waiata and poetry is Erihapeti Murchie, a rangatira me wahine toa of Kai Tahu, Kati Mamoe, Waitaha and Ngāti Raukawa. Born and 
raised at Arowhenua, near Temuka, her work encapsulates the definition given above and she is a good example of a Māori woman who wrote about living in the Pākehā world and Te Ao Māori, and who had achievements in both, beyond most people's ability to succeed in only one. While at Christchurch Teachers' College Erihapeti met and married Malcolm Murchie, a Pākehā from Whanganui. Together they had ten children and both shared a common interest in politics, the arts, conservation and social justice, attending rallies against apartheid in South Africa and the Vietnam War. In an unpublished memoir titled 'What I Believe' Erihapeti stated:

My attitudes and my hierarchy of beliefs have filtered through from the ancestral past of a largely dispossessed takatā whenua (people of the land - the Māori) ... my people will retain their status as kaitiaki ö te mauri ö te whenua (custodians of the spirit of the land) ... shaping of a culture distinctly Aotearoa New Zealand that blends Polynesian with other European elements (Murchie, private papers: unpublished).

Along with her Ratana religious beliefs these kaupapa underpin Erihapeti Murchie's life. She did much to help her people both formally and informally. When her family moved to Dunedin she was instrumental in obtaining the site for the urban marae, Araiteuru, and her whānau would awhi many young Māori students living in the predominantly Pākehā city of Dunedin in the 1960s and 1970s. Among her many official positions she was National President of the Māori Women's Welfare League, 1977 to 1980. During this period she completed a Māori research project, Rapuora Health and Māori women, and she was active in getting government policies changed in Māori health, te reo Māori, and education. In 1989 Victoria University conferred on her an Honorary Doctorate in Law.

Coupled with these outward achievements, Erihapeti Murchie also composed and taught waiata to her whānau to ensure they understood and remembered their ancestral links to Kai Tahu and Kati Mamoe. When she died in 1997 the Kai Tahu whakatauki 'Whaia ki te tei tei' (reach for the highest peak) was given to her whānau in recognition of her achievements. One of Erihapeti Murchie's waiata shows her talent for composition on the spot. At the tangi of Kai Tahu leader Tipene O'Regan's father there was no 
song for his poroporoaki so she was able to sing this waiata atāhua, 'Papaki te Tai', which she composed spontaneously:

Papaki te tai ki uta ra

Whatiwhati te waka, tere ino ki raro ra,

Tumokemoke te iwi ki raro e,

Te korowai o te Aitua, o kaa roimata e,

Takihia mihia poroporoaketia

Haere hoki e te wairua ki kaa tupuna e

Waihoa matou hei whakawhiriwhiri

Te ara tika mo kaa mokopuna

I tënei Ao hurihuri e

'Waves crashing'

Waves crashing against the cliff, The waka is broken down below,

The iwi sit in sadness under,

The cloak of the Aitua, and tears

We've wept, mihied,

The spirit has returned to the tipuna,

And we will remain to seek

The right path of the mokopuna

Within the changing and turning world

(Murchie, private papers: unpublished).

A poem, 'Awarua (Te Hura Kohatu)', written at Arowhenua sees Murchie in a reflective mood, thinking about the impermanence of life and her interpretation of and affinity with nature:

I have a passion here

For quiet waters brooding deep

In the curve and sweep of a narrow trough meandering

Through willowed banks,

And languid in its flow

The white dressed cress is haunt

To the water crabs and speckled trout

That taunt the dragon flies

Skimming the stream 
And slim black eels within,

Aloft in trembling flight

The flick flack tiwaiwaka

Pirouetting its delicate haka

And the Little White Bridge

Triumphant stands still

To spring floods,

But life is ever changing

With voices stilled and the richness

That the tidal flow is witness to

Has ebbed - and Awarua

No more chatters

Free from the bridge below.

(Murchie, private papers: unpublished).

Māori researcher, historian, and composer of waiata, Charles Royal, has written about the aspect of Moteatea that Murchie evokes so well. Whilst Royal is talking generally about the art form in an historical context his words could equally apply to her writing. Royal writes:

Clearly Māori did and do create poetical compositions which might be described as literature, particularly oral literature; yet the term fails to capture the entirety of the tradition. For example, most writers in the West have since the Renaissance intended their works to be represented on the written page. Moteatea [Māori song or poetic composition] composers on the other hand conceive their work essentially for performance, while the 'literary' quality of the texts cannot be denied (Royal, 1998: 346).

\section{Maewa Kaihau}

Another example of a Māori woman writing, this time early in the $20^{\text {th }}$ Century, is Maewa Kaihau, who wrote the words to the tune Now is the Hour which began as a modified Swiss lullaby for the singing of Po Atarau to farewell Māori World War One soldiers. In 1920 Kaihau wrote a This is the Hour verse, and in 1935 she again adapted the Po Atarau verse. This became the Haere Ra Waltz Song, which was sung when steamships were departing New Zealand for overseas. English wartime singer Gracie Fields learnt Haere Ra on a visit to New Zealand in 1945. Her version of it, known 
as Now is the Hour, became a world-wide hit in 1948. The first and last verses became extremely popular, and Kaihau claimed that all the words and tune were her own work.

Kaihau's words were not copyrighted until 1928 and more recently Dick Grace has claimed most of the words as the work of his family. In those days before radio and before locally-made recordings, the lyrics of this song were probably being changed constantly according to circumstance and memory, and Kaihau's genius was to mold a version whose words could be understood and appreciated by both the Māori and Pākehā communities:

Perhaps the chief factor contributing to the success of Now is the Hour as a representative New Zealand song is its reflection of the Māori/English amalgamation fundamental to the national fabric (Annabell, folksong.org: 2007).

in much the same way that Te Rauparaha's haka 'Ka mate/ka ora' is nowadays.

\section{Te Ao Hou}

For the Māori women writers who did make it into the print medium in the 1960s, including Grace, their main vehicle for publication during the period covered by this thesis was the Māori Affairs Department magazine, Te Ao Hou. Were it not for Te Ao Hou and the New Zealand School Journal many Māori women writers would conceivably not have entered into 'the world of light' at all. In an early 1970s edition of the magazine an article 'The Māori Contribution to New Zealand Literature' states:

Māori poetry is distinguished from prose by: -

(a) the fact that it is fixed-form - once the composition has been set in its frame and polished by the author, it is repeated word for word in song form, subject occasionally to slight modifications (a word is changed or a line is dropped), due to errors of memory or dialectical differences.

(b) by its manner of delivery, which is essentially musical. 
(c) by certain distinctive stylistic features such as the stylisation of metaphor, symbolism, allusion and ellipsis.

Māori poems abound in these, be they dirge, lament, lullaby, ditty, love song or derisive song. They all breathe the spirit of place, evoke the very clap of thunder, flash of lightning, lash of wind and rain, caress of zephyr, moon and sun, pungent sense of environment and climate, intimacy in the colour and drama of landscape. Although there are some fine translations of Māori song poetry, ritual chants, watch alarms, etc, they do not always capture the rhythms of speech, the undulations of melody, the music of words that soothe the ear, move the mind, rouse the spirit and stir the imagination (Anon, Te Ao Hou 1973 No. 71: 36, 37).

The article points out that a further distinction between poetry and prose is its manner of delivery, which is essentially musical. Karakia, canoelaunching chants, poi chants, and laments were often composed and performed by women. A good example is Tangikuku's lament in which she likens herself to a cicada that is short-lived and very soon to die. She was a poetess who was so emaciated by asthma that she could not join a party of women on their way to the rocks to dive for crayfish and gather sea-eggs and paua, thus her lament.

The article went on to state that the classic chant 'Piki mai, kake mai' was a tribute to writers who 'bring light' into the world and suggested:

Overseas scholars who have studied Māori oral literature are astounded by the variety of literary forms and devices, by the depth of speculative thought, the vividness of imagery, the wealth of cultural allusions, and the rhythm of tragic and beautiful phrases (Anon, Te Ao Hou 1973 No. 71: 36,37$)$.

\section{Arapera Blank}

Among the Māori women writers of the time between 1945 and 1970 two stand out as having a literary profile in the general literary world. Arapera Blank and J.C. Sturm were both published authors as well as regular contributors to $\mathrm{Te} \mathrm{Ao} \mathrm{Hou}$. For example, Arapera Blank won the prize for the best short article in the Katherine Mansfield Memorial Competition for 1959. 
Her article described kumara growing in her district, the isolated northern area of Rangitukia. It was published in Te Ao Hou in October 1958, and was her first attempt at writing. The distinction of winning a Mansfield Memorial Award was considerable. Maurice Duggan won the short story award, and Elsie Locke the non-fiction one. The sponsors (the N.Z. Women Writers Association and the Bank of New Zealand) decided to add two further awards, one for the best short article, won by Arapera Blank. The official announcement read as follows:

Another excellent entry was placed top in the short article division. Mrs Arapera Blank had been placed top of the shorter articles for her entry Ko Taku Kumara Hei Wai-U Mo Tama in the Māori Affairs Department publication $\mathrm{Te}$ Ao Hou. Her article was written in English. Mrs Blank is a Māori writer and a teacher at Punaruku. Her work has developed through the opportunities given to Māori writers through $\mathrm{Te}$ Ao Hou. It is arresting and creative. For the excellence of the above two entries (the other was by O. E. Middleton) the Bank of New Zealand decided to make additional prizes of fifteen guineas each ... (Anon, $\mathrm{Te}$ Ao Hou December 1959, No. 29: 4).

\section{J.C. Sturm}

Jacqueline Cecilia Sturm (J.C. Sturm: Taranaki, Whakatohea), was born in Opunake in 1927 and is a writer of short stories and poetry. In the late 1940s her poetry was published in student newspapers and the Otago University Review. As discussed in the previous chapter she married the poet James K. Baxter in 1948. In 1950 she began an MA in Philosophy at Victoria University, writing a dissertation on 'New Zealand National Character as Exemplified in Three New Zealand Novelists', which was commended as being of exceptional merit and awarded first class honours.

Sturm's story 'For All the Saints' became the first story written in English by a Māori writer to appear in Te Ao Hou. Throughout the 1950s and early 1960s she featured regularly in $\mathrm{Te} \mathrm{Ao} \mathrm{Hou}$, both writing and reviewing. Editor C.K. Stead included Sturm's story 'For All the Saints' in New Zealand Short Stories: Second Series (Oxford University Press, 1966), making her the first Māori writer selected for a New Zealand anthology. 
Early in the 1950s she began writing short fiction: in 1954 her first story 'The Old Coat' appeared in the first issue of the quartley literary magazine numbers and in subsequent issues until it finished in 1959. Aorewa McLeod and Paul Millar in their entry for The Oxford Companion to New Zealand Literature say of Sturm's work that the stories are succinct and lucid and on first reading they appear to embrace the era's dominant ethos, which was that New Zealanders were one nation, by avoiding specific reference to Māori. However, they continue, reading against the grain of thought that expected all Māori to become respectable middle-class citizens, in other words a lighter shade of brown, and it becomes clear that the society she depicts fosters inequality, and her work conveys a strong and poignant sense of alienation.

According to McLeod and Millar, J.C. Sturm's female narrators, although rarely defined by their race, are marginalised figures that give a vivid sense of the constriction and constraints of a young woman's life in Wellington in the 1950s. They quote Lydia Wevers who notes that by supplying 'the missing term 'Māori' Sturm's stories fall horrifyingly into place' (Wevers, 1998). Sturm herself commented that 'whether my work has any [overt] Māori content or not we're talking about a way of looking, a way of feeling and a way of being' (Sturm in McLeod and Millar OCNZL, 1998: 518).

By 1966 Sturm had a collection of stories ready for publication, but no publisher. In 1969 she became a solo parent and the pressures of earning a living left her little time for further writing for over 20 years. In 1982 two stories, 'First Native and Pink Pig' and 'Jerusalem, Jerusalem', were featured in the anthology of Māori writing Into the World of Light co-edited by Witi Ihimaera. Then the women's publishing collective Spiral printed her stories in 1983 as The House of the Talking Cat which was shortlisted in the New Zealand Book Awards. In a 1984 article Ihimaera called her a 'pivotal presence in the Māori literary tradition' and speculated on the course Māori literature might have taken had 'J.C. Sturm and Cat achieved success and publication in their time, rather than twenty years later' (Ihimaera, 17 March: 1984). 
In the decade following the publication of The House of the Talking Cat Sturm returned to writing poetry. Through her experiences of loss and love, youth and age, and Māori and Pākehā, Sturm's verse conveys a sense of tranquillity and acceptance of the dualities inherent in her own eventful life. In 2003 she received an honorary Doctor of Literature degree from the Victoria University of Wellington. J.C. Sturm's place in the sociological and psychological context of the period and the remarkable achievement of her writing and life as a contribution to the present generation of Māori women and her insight about how Aotearoa New Zealand is developing is expressed in an article she wrote for Te Ao Hou in 1954:

When I was preparing this article, some one asked me why are the Māori WOMEN in the vanguard of welfare work? Does this imply that the status of women in the Māori community at large has changed, giving them more say in all matters Māori? Frankly, I do not know. But I would suggest that nearly all the disadvantages of the Maoris' position are felt most acutely in the home, so that it is the women, not the men, who have to cope with them daily, understand them more fully, and are most strongly moved to do something about them. If the explanation is more complex than this, if the Māori women today really have more vigour and initiative than the men, well, good luck to them! (Sturm, Te Ao Hou No. 9, Spring, 1954: 8).

A recent visual biography has been made of Sturm's life titled, 'Broken Journey: The Life and Art of J.C. Sturm'. ${ }^{1}$ At the time aged 80 , Stum reflects on her life and the influences that shaped her writing, including her early years in the Taranaki coastal town of Opunake, as well as the impact of her local pā, Parihaka. The title refers to her 'broken' writing career as she had to attend to family matters from the late 1960 s to the late 1980s, first being a deserted wife and then a widow, as well as bringing up her granddaughter from-infancy, and working as a librarian.

In her later years J.C. Sturm has become a renowned kaituhi (poet) in her own right. The film's director, Tim Rose, says the hour-long documentary is an intimate story of a long, well-lived life. As she tells the story of her life, a narration in the Māori language paints the picture of parallel events in New Zealand society - the depression and the war, urbanisation, the changing role of Māori women, and Māori women in literature. Originally, she makes 
the point in the film, in the 1950s and 1960s she felt she was 'not a poet' as she thought she was not in the same league as her famous husband and his literary friends.

Another consideration as to why Sturm switched from poetry to prose, as she did at this time in the 1960s, could be due to a prevailing idea that men could write poetry and women couldn't. For example, one of her husband's colleagues, Louis Johnson, with whom Baxter co-edited the literary quarterly numbers stated:

Since we've been asked to look at the problem in this battle-of-thesexes way, we might generalise that our women contributors appear to be more proficient at prose than with poetry (Johnson, 1957: 28).

Sturm reports that she would show her husband poetry she had written and he would simply say nothing, neither good nor bad. While this may have been his way of not wanting to appear biased, she found this a most disconcerting experience.

Rose, from the Paekakariki-based Kapiti Productions, whose parents lived next door to the Baxter whānau in Wellington, reports that he knew Jacqui:

pretty much since the day I was born. I have spent time with Jacqui in the last couple of months [while making the film] talking with her about her life and the things that have influenced her writing. The more time I spend, the more the stories flow. At times very personal, they weave from home and family to literary history and culture in an ever changing story. It's a jigsaw of treasures, each piece essential to the other and in total, the key to national knowledge and collection (Rose,www.throng.co.NewZealand/documentary/broken-journey-thelife-and-art-of-jc-sturm:website).

J.C. Sturm died on the $30^{\text {th }}$ of December 2009, her tangi was held on her home marae near Opunake and later she was farewelled in a moving ceremony and celebration at Paekakariki, the seaside village on the Kapiti Coast where she lived much of her adult life. In an obituary by fellow poet Jeffrey Paparoa Holman, he called her 'a pioneering literary figure'. Holman continued: 
Her Māoriness became a very private thing to her and still is ... Baxter's sudden and precocious appearance in New Zealand's literary firmament in the 1940s overshadowed much of her adult life. Moving among the male-dominated literary circles of a vigorous Wellington artistic community during the 1950s and early 1960s, Sturm found an editorial champion outside of Pākehā gatekeepers who could not conceive of a Māori literary tradition: Erik Schwimmer [who] managed to persuade the conservative Māori Affairs department to fund a journal of Māori writing, by Māori, for Māori, Te Ao Hou, which he then edited. Seeking out Sturm, he asked her for a story ... Sturm's late-blooming literary career began in earnest, and when she turned again to writing poetry in the 1990s, her real talent in forms other than prose fiction was apparent ... like many women writers of her generation, [she] had to sacrifice their gifts and abilities on the altar of domesticity. In her case, she had also to carry the burden of being a Māori woman in her generation (Holman, Dominion Post 11-1-2010).

We may conclude that the development of Māori writing would have been greatly enhanced if this talented writer had been able to publish her work during an earlier period.

\section{Tuini Ngawai}

The following excerpt from an editorial in the April 1956 issue of $\mathrm{Te} \mathrm{Ao} \mathrm{Hou}$ indicates how highly literary prowess was held in Māoridom, but also shows how little was known of the flourishing Māori literary scene in the wider literary world, and the fact that many writers and poets were women, as demonstrated by this article about Tuini Ngawai:

The publication in this issue of the winners of our first successful literary competition is a landmark for $\mathrm{Te} \mathrm{Ao} \mathrm{Hou}$.... There have been Māori writers since the alphabet was introduced. Many of the beautiful stories published in Sir George Grey's Ngā Mahi a Ngā Tupuna were originally written by Māori historians ... Fine examples of Māori writing are found in magazines like Te Waka Māori, Te Hokioi, Te Wananga, Te Pipiwharauroa, Toa Takitini, The Polynesian Journal, and so forth. Much of the best writing by Māoris today is in English ... [however] the preservation of the Māori tongue depends on its continued use for literary purposes, as in song and oratory. As there are only a limited number of people who reach a high standard in literary Māori, they do a great service by publishing their work so that their example can be more widely followed ... writing is a very important activity and Māori writers 
do a great service to their race. Most Māoris think a good deal about their people and the things that affect them. To a great extent, the future of the people depends on how good that thinking is ... [they] may describe how a meeting-house was built, or how the old people used to live, or what it feels like to live in a town, or to own a taxi business ... The subjects need not be practical. Family life, love and death, have been subjects for writers and poets from time immemorial. ${ }^{2}$ People like to tell stories and people like to listen to them (Anon, Te Ao Hou No. 14, April 1956: 1).

Tuini Ngawai was descended from Te Whānau-a-Ruataupare ō Ngāti Porou. Her teaching career ended in 1946, when she took on the leadership of shearing gangs. Ngawai expected strict standards from her workers, and won the women's section of a shearing competition. Many of her songs commemorating Māori shearing gangs are still sung on the East Coast. From 1946 she also became involved with the Kotahitanga movement, which sought to restore Māori pride and identity through cultural revival. She assisted the tohunga Hori Gage in his healing ministry, and she was involved with efforts to achieve greater recognition for the Treaty of Waitangi.

Ngawai voiced her deepest feelings through the words of songs such as 'Te Kotahitanga ra e' and from the mid 1940s to 1963 Tuini put to use her versatility with a number of instruments, especially the saxophone, by leading a six-piece band she named the ATU Orchestra. Most of her songs were set to popular tunes because, for Ngawai, their vital message lay in the words rather than the music, and the performers had to learn the songs by heart as quickly as possible for each new occasion. From 1953 Ngawai entered her senior cultural group from Te Hokowhitu-a-Tu in the Tamararo Māori cultural competitions held in Gisborne.

Ngawai trained and entered two youth groups and most years these three groups represented Tokomaru Bay in the annual competitions. She wrote many songs for these events, including 'Piki mai kake mai', to commemorate the ancestor for whom the competitions were named. Ngawai and Te Hokowhitu-a-Tu sang her song 'Te Tiriti o Waitangi' before Queen Elizabeth II during her tour of 1953-54. Another famous song of the 1950s was 'Nau mai, haere mai', written to welcome the 1956 South African rugby team to Gisborne. Anaru Takurua writes of Tuini: 
She was a perfectionist with an unrelentingly high standard, although she allowed for individual style and did not insist on a rote-learned unison in cultural performances. Although a Ringatu she assisted other churches with their choirs, in combined worship and in Māori cultural activities. Her greatest contribution to other churches was in leading a Mihinare (Anglican) culture group at the all-Aotearoa Hui Topu Māori held at Turangawaewae marae in 1962. For this occasion she wrote 'Matariki', one of two songs she penned to acknowledge her King movement hosts (Takurua, DNZB website: 2007).

In the Te Ao Hou No. 14 issue there was an article on her as a poet/songwriter Ngawai:

The first person I met on Makomako station was the manager. He seemed rather surprised to hear that to-day's leading Māori songwriter was at that moment working in his shearing shed, but at the name 'Tuini Ngawai' he showed recognition. Yes, she was there. But, he added, to see her in the shed, you wouldn't believe she had composed any songs (Anon, Te Ao Hou No. 14, April 1956: 46).

The author of this piece in Te Ao Hou is an unnamed Pākehā writer who wanted to translate her songs and is overwhelmed by this Māori song-writer whom he finds has 'a consciousness of the hidden depths of the mind that is in general more typical of writers than shearers.' (Anon, Te Ao Hou No. 14, April 1956: 46)

This did not surprise me, however, as I have worked on many labouring jobs. Whether it was laying tracks on the railway or digging drains I often found more kindred 'poetic spirits' among labourers, particularly Māori and Polynesian and those of Irish descent, than I encountered in the 'career conscious' atmosphere of university or intellectual circles. The $\mathrm{Te}$ Ao Hou article noted that like many poets, Ngawai has had words dictated to her by something outside her consciousness, 'in a dream,' she says.

For example, Arohaina Mai which she regards as her best song, took only a few minutes to compose but like many writers the words come from subconscious thinking over many years and experiences; like the English Romantic poet William Wordsworth's definition of poetry, 'experience reflected in tranquillity'. And the politics behind much of Ngawai's works are clear. The Māori people, she said, were still wonderful singers, but actions for 
the songs were often poor due to the words not being understood fully or even at all. She thought that teaching action songs in schools would be unrewarding unless the language was also taught. Ngawai said that she liked the shearing routine and liked to live for a while with young people and to keep in touch with how they felt. The author finished his $\mathrm{Te}$ Ao Hou article in a pertinent fashion:

After my visit to Makomako we travelled back together on the shearer's truck. In the middle sat Tuini singing. Twenty voices joined in with gusto. Someone offered her a guitar but she turned it down. She just continued singing. With the next song she had changed her mind, she now wanted the guitar and took it. Strumming this guitar, she was completely part of her people; as they were singing her songs she could see how they experienced them, what feelings were stirred. After thousands of years of civilisation European poets are still dreaming of rediscovering this lost unity with the people (Anon, Te Ao Hou No. 14, April 1956: 48).

Ngawai died on August 20 1965. At her unveiling hui in 1966 the dominant theme of the sentiments expressed was that she was a genius, unique, and that her like would never be seen again. Her great contribution as a composer of around 300 songs would live on:

many of which had become classics, and the stories behind them were retold and relived during the hui. Her compositions comprise action songs and songs of lament, love, war and comedy. (Anon, Te Ao Hou No. 55 June, 1966: 38)

In The Oxford History of New Zealand Literature in English Jane McRae, writing on Ngawai, says that:

an account of her life and texts of many of her waiata are to be found in Ngoi Pewhairangi's Tuini. Her Life and Her Songs (Te Rau Press, Gisborne, 1985), a book compiled and published by her tribe who wished to preserve her work for future generations (McRae, 1998: 19).

Apart from Patricia Grace and J.C. Sturm, both of whom contributed to Te Ao Hou during the 1960s, there was not much evidence to suggest that Māori 
women made any impact on the New Zealand mainstream 'literary' scene during the period of this study.

However, Grace had work published in the 1960s in the School Journal and along with Ihimaera signalled a shift in the way Māori were to be seen in the literary world. It may seem odd that Sturm was not among the regular writers for the School Journal, as her husband, Baxter, was on the editorial staff. But as she said in the film 'Broken Journey' in the 1950s and 1960s she felt she was 'not a poet' as she thought she was not in the same league as her famous husband and his literary friends. As Gregory O'Brien notes in $A$ Nest of Singing Birds:

While the 1948 series Life in the Pā and the 1960 Māori Issue of the Journal had been largely produced by Pākehā, ${ }^{3}$ the significant shift during the 1960s and early 70s was the upsurge in Māori contributors. During that period, Witi Ihimaera and Patricia Grace became prominent names in the School Journal, their writing deliberately setting out to fill the void they had personally felt as young Māori reading the Journal. Both contributed first-hand accounts of Māori experience in the contemporary world (O'Brien, 2007: 71).

\section{Renée}

I am a personal friend of Renée Taylor, playwright and novelist of Māori descent. For the purposes of this study I asked her to write something about her career. She responded by e-mail and I quote from her reflections in this section. Renée Taylor became a dramatist of repute in the 1980s and has since used the name Renée as both her pen name and the name she prefers to be known as generally, with no surname attached. While most people in the New Zealand literary world know Renée as a feminist dramatist and fiction writer who began writing plays in 1979 , at the age of $50,{ }^{4}$ her literary life began much earlier.

Renée was born in Napier in 1929 and is of Ngāti Kahungunu and IrishEnglish-Scots ancestry. Renée left school and started work at an early age and has worked in woollen mills, a printing factory, a grocery-dairy, and as a feature writer and reviewer. Renée has described herself as a 'lesbian 
feminist with socialist working-class ideals' and most of her writing is a direct expression of that conviction. Much of her writing is also an expression of her Māori background, especially as the initial inspiration for her becoming a writer came through reading such publications as $\mathrm{Te}$ Ao Hou.

In the late 1950s Renée was living in Greenmeadows (just out of Napier), Hawke's Bay, in her 20s, married, with three sons. Her then husband was a hard worker and a good father to the kids. She continues:

When I decided to begin writing I knew clearly that I wanted to write to sell. I wanted to be a writer whose work editors paid for. So I started to write, at first light, funny, domestically based articles. I read every article of that kind I could get and began. My husband bought me a secondhand typewriter and I was away. I got rejections at first but quite soon acceptances. These were from the New Zealand Free Lance, the Hawkes Bay Herald-Tribune. I read about a group called the Hawkes Bay Branch of the New Zealand Women Writers' Society and I rang up the secretary of the local branch at the time, Eve Ebbett, who wrote light romances (under the name Eva Burfield) that were published in England, and who also later wrote other non-fiction works, among them When the Boys Were Away. Rachel McAlpine interviewed her for The Passionate Pen (Renée to Michael O'Leary, 1/2/2010).

Eve Ebbett invited Renée over to Hastings and asked her to bring her work. By then Renée had a fairly substantial pile of published and unpublished stories and articles. Ebbett always remembered and told the story many times of Renée arriving at her place and when she opened the door, she saw this young woman with this huge pile of paper under her arm, and Ebbett said of Renée 'I knew then she would make it'.

Renée submitted her application, along with three published articles, and was accepted as an associate member of the New Zealand Women Writers' Society. She joined the Hawkes Bay Branch, and in between meetings wrote as much as she could. She sold stories to the Mirror, a glossy magazine of the time, continued selling articles to newspapers and later to a magazine called Eve. Renée says:

I read Te Ao Hou and anything else I could find which published works by Māori. When we moved to Wairoa, I began to research and investigate the Māori side of my family - and also wrote a weekly article 
for the Wairoa Star. While I was in Wairoa, I decided to study towards a BA degree (Renée to Michael O'Leary, 1/2/2010).

Renée had left school at twelve to go to work, and wanted to give herself this present of higher education. It took her ten years, because she could only take 2 papers a year. She did her last papers at Auckland University, and after graduation decided it was time to do the one job in theatre she had never done. Renée wrote:

I had been working in theatre since I was in my early 30 s and had done every job one could possibly do from front of house, designing sets, painting sets, acting, directing, prompting, making cups of tea, you name it, l'd done it (Renée to Michael O'Leary, 1/2/2010).

Subsequently she has been involved with community theatre, the Broadsheet Collective, PEN, radio shows, programme organisation for the Globe Theatre in Dunedin, and with script writing for TV.

In this chapter I have considered the constraints on the work of selected Māori women writers, all of whom, had they been able to publish in mainstream literary anthologies and journals in the period 1945-70 mayhave significantly changed the direction of indigenous New Zealand writing. It appears from both Sturm's own words and Ihimaera's later appraisal of her place in New Zealand literature that the work and thought of Aotearoa/New Zealand Māori women writers were both active and alive during the 1950s and 1960s but were also limited by their lack of publication opportunities and family and personal commitments.

Even Arapera Blank winning a prize in the Katherine Mansfield Memorial Competition did not translate into mainstream acceptance. Were it not for Te Ao Hou many Māori writers, including Sturm and Blank, conceivably would not have entered into 'the world of light' at all. That Renée not only identifies as a Māori writer but is also one of our foremost lesbian writers leads into the next chapter on lesbian writing. 
1 'Broken Journey' screened for the first time on Māori Television's New Zealand Documentary slot, Pakipumeka Aotearoa, on Wednesday October 17, 2007.

${ }^{2}$ It is interesting to note that 'family life, love and death' are not considered by the editor to be 'practical' subjects. It is highly likely that this particular editor is a man rather than a woman for in the Māori world, and many other worlds, these three things are definitely 'practical' things to be taken care of by the women in that particular society.

${ }^{3}$ Margaret Orbell contributed many retellings of Māori legends to the School Journal during the 1960s. She was also editor of Te Ao Hou from 1961 to 1965, and in 1978 she edited a book Māori Poetry: An Introductory Anthology. Another Pākehā writer, Barry Mitcalfe, had preceded Orbell by producing a book of translations, Poetry of the Māori, in 1961.

${ }^{4}$ Until recently few plays by New Zealand playwrights have been published in book form. In the 1970s there were editions of James K. Baxter's plays commissioned by the Globe Theatre in Dunedin. One book titled Five New Zealand Plays was published in 1962. Interesting, of the four playwrights represented, three are women. 


\section{Chapter 9}

\section{Lesbian Writing in New Zealand}

In this section I consider lesbian writing and the representation of lesbian characters and subject matter in New Zealand literature 1945-1970. This broad approach reflects the reality of pre-1970 lesbian life in New Zealand. Many women did not overtly state their sexual identity although their work, in retrospect, does reveal a lesbian perspective for some readers. The 'closeted' nature of lesbian and gay lives in the pre-1970 era has been examined by Wellington academic, Alison Laurie (2003). She writes: 'Though the term 'lesbian' remains the oldest term still in use for women's samesexual relationships, the meaning changed following the influence of lesbian feminism'. Laurie states:

I use the term 'lesbian' as Terry Castle suggests, in the dictionary sense of a woman 'whose primary emotional and erotic allegiance' is to other women [Castle 1993, p.15], and my use is not intended to suggest post1970 political meanings or forms of self-identification for the women in this study. Rich [1980] used the idea of a 'lesbian continuum' to include 'woman-identified experience' whether sexual or not (Laurie, 2003: 24).

Laurie says definitions of lesbianism that do not take account of the strategies of invisibility, silence, deception and discretion necessary for pre1970 lesbian survival, prevent scholars from locating earlier lesbian lives, and this is certainly the case of some of the New Zealand women writers of the period 1945-1970.

While there is evidence to suggest over the years that many women's 'primary emotional' life may be directed to their women friends, this may not be their primary 'erotic allegiance'. Examples of these close relationships can be found in memoirs such as Burgess' personal portrait of Eileen Duggan. An example from another era can be found in Ellen A. Proctor's beautifully written memoir of the English pre-Raphaelite poet Christina G. Rossetti. These examples reflect Rich's earlier comment that such intimate personal 
relationships are 'woman-identified experience' whether sexual or not, as Laurie observed (Laurie, 2003).

Laurie quotes Emily Hamer who argues that 'one is a lesbian if the life that one lives is a lesbian life' suggesting identifying the life as lesbian, rather than the woman (Hamer 1996, p.10). She recommends that scholars should decide women were lesbian, when that is 'the best explanation of their lives', pointing out that, 'the standard of visibility is not a universal prerequisite for knowledge'. Laurie continues by quoting Lillian Faderman:

Many women's lives were engaged in a necessary performance of heterosexuality by 'donning women's drag (both literally and figuratively)', in order to allay social suspicions (Faderman, 1999 p10) ... they lived lives of invisibility and silence to protect their lovers and their relationships (Laurie, 2003: 25).

The visibility of lesbians in early New Zealand literature was not necessarily through the publication of lesbian women's writing, but through lesbian characters that emerged in fiction by men and heterosexual or bisexual women writers. As Lawrence Jones notes:

Lesbian characters have likewise been brought into the open in the 1980s and 1990s, no longer treated indirectly as in Sargeson's 'I for One .... Lesbian relationships occur at least as a secondary theme in such novels as [Marilyn] Duckworth's A Message from Harpo and Seeing Red, [Barbara] Anderson's Girl's High, Stephanie Johnson's The Heart's Wild Surf, Michael O'Leary's Straight (1985), and Noel Virtue's Always the Islands of Memory. Most of these depictions are sympathetic or, more tellingly, neutral in the sense that lesbianism is simply one of the aspects of a character to be noted (Jones, 1998: 201).

I focus on women whose writing and subject matter helped create a pathway for future lesbian writing. These women writers, although most not within the period of this thesis, became the voice for 'the other' in female characters in New Zealand fiction: they are, in the following order: Ursula Bethell, Eve Langley, Jane Mander, Katherine Mansfield, Ngaio Marsh, Esma North and Marjory Nicholls. Each wrote strong female characters who aspired to become artists, writers and/or women of independent means, reflecting a growing dissatisfaction among some women of a life as a mere handmaiden 
or wife to a man. None were overt about their attraction to women as lovers, although many of them had sentiments and characters in their work that inferred love between women.

McLeod, in a paper published in Lesbian Studies in Aotearoa (McLeod, 2001) uses Castle's concept of 'ghosting' lesbians to inform her study of New Zealand's 'lost lesbian writers and artists', giving as examples the lives of Margaret Escott, Jane Mander and Ngaio Marsh. She discusses New Zealand novelists, a poet, and a painter, whose identities as lesbians have been obliterated in biographies and critical commentaries. She considers whether the small and largely mono-cultural New Zealand literary and artistic scene made both coming out and being identified as a lesbian more difficult than in Europe or the United States. McLeod concludes that even in the 1990s, 'ghosting' lesbians of the past was still prevalent.

Castle suggests a ghost is something absent, immaterial, not palpable. If one thinks of a ghost as something that keeps appearing, keeps exerting an influence, something that has the power to haunt us, this is what McLeod implies as the position of women writing about lesbian experience in New Zealand literature. McLeod reminds us that 'Mander, Marsh, Escott, and in the art world Hodgkins, all lived before second wave feminism and gay liberation came to New Zealand in the early 1970 s and made lesbian visibility possible' (McLeod, 2001: 59). In the 'Other' category McLeod argues that New Zealand writers were silenced by being 'ghosted', in the sense that Castle observes, not specifically acknowledged or examined as lesbian writing, including Mander, Escott, and Bethell. Some were ridiculed as being 'unwomanly', for example, by Fairburn (1967), as in Chapter 5 of this thesis on the women poets.

Laurie states that though lesbian sexual acts were not criminalized in New Zealand, lesbianism was 'contained, regulated and controlled through a variety of mechanisms, including the fear of forced medical treatment, social exclusion and disgrace, as well as the loss of employment, housing and family relationships' (Laurie, 2003: 2). While we have seen elsewhere in this thesis that these fears were not confined to lesbian women, but in some 
times the confines heterosexual women had placed on them, lesbians were even more affected. Class and race were also significant determinants.

Laurie writes of the secrecy and silence of self-censorship that often meant the deliberate destruction of written records such as letters or diaries, by women themselves, or later by family members and friends to hide the perceived shame of a lesbian relationship; again this is not unique to lesbianism. For example, in her short story 'The Day of the Funeral', Isobel Andrews' character Della, who has been at the beck and call of an old aunt for several years whose funeral is the subject of the title, in an internal monologue says: 'As soon as this business is over l'm going to clean out that room. I'm going to burn all those letters. I'm going to send all that lace to a junk shop' (Andrews, [c1940s]: 5-6).

Laurie concludes that the private lesbianism of most pre-1970 lesbian lives cannot be understood in isolation, and that scholars must move beyond the women's masquerades to place their lives into a lesbian context in order to recognize and understand them. She argues:

Each life informs an understanding of the others and by considering them together the study provides a picture of lesbianism in pre-1970 New Zealand, with the stories of the narrators illuminating the written experiences. Silences should not be mistaken for absences, or heterosexuality assumed for all pre-1970 New Zealand women (Laurie, 2003: 4).

It is with these thoughts in mind that I approach the writers and their work by linking their biographical evidence to their writing to show the interconnections between real life experiences of the writers and experiences expressed through creative fiction. Pre-1970s offerings in fiction on any kind of homosexuality were subdued and meagre. ${ }^{1}$ Mansfield's stories contain some lesbian themes. However, until women like Ngahuia Te Awakotuku, Miriam Saphira and Cathie Dunsford in the 1970s and 1980s announced themselves as lesbians, it was difficult to know whether women writers identified as lesbians or not.

Another woman in the struggle to have women's work taken seriously is poet Heather McPherson of the Spiral Collective. McPherson is a personal 
friend and I have published her work (McPherson, 2004). Early in her career she realised that she would have to take up the fight against the male establishment when she told Leo Bensemann, then editor of Landfall, that she had a collection of poetry and would he look at them; his response has been recorded earlier in the abstract to this thesis and it was in the face of negative attitudes like his towards feminism (even though Bensemann said her poems were publishable) that she knew the battle lines were drawn.

McPherson states that after joining a group to fight for homosexual law reform 'with a number of talented women artists in the group, with their stories being turned down for publication or by art galleries, I thought I would rather be working with/for women artists' (McPherson, 2007:117). ${ }^{2}$ Thus the Spiral Collective was formed to provide an alternative to the male literary and artistic establishment.

What follows is a brief study of some of the writers around the time of this study who have been claimed in recent years by women's groups and academics as being part of the lesbian canon in the literary history of New Zealand. As noted earlier one interesting aspect this thesis has looked at is that while the period 1945 to 1970 provides virtually no overtly or even covertly lesbian literature, there is evidence that pre-1945 women writers were recognised as having intimate relationships with other women, whether sexual or not remains in the realm of speculation.

\section{Ursula Bethell}

While not strictly from the period this study covers, Bethell died at Christchurch in 1945, she is an example of the often ambiguous nature of some women's lives, and her oft presumed 'lesbian' lifestyle had an influence on later generations of writers. Having lived in England during WW1 Bethell returned home to Christchurch and built a house in Cashmere, 'Rose Cottage', where she lived for 10 years with Effie Pollen, a younger woman who came from Wellington to be with her. At the age of 50 Bethell began writing poetry. While Bethell mentored poets and artists of the time, Pollen 
kept the house in what was an almost 'traditional' marriage situation, although visitors commented that each woman had her own room.

After Pollen died suddenly in $1934^{3}$ Bethell was devastated, writing a 'Memorial' poem to her every year for the next six years on or around the anniversary. These poems of grief to her have become an intimate and lasting gesture of love to the woman she shared her life with. There is no formal acknowledgement of any specific 'lesbian' relationship between the two women and perhaps her Christian beliefs meant that she could possibly never acknowledge this even to herself.

The question may be asked: Was Bethell's sexuality a deterrent to publication? It is difficult to say - because in one sense, it was her class that allowed her to live in a lifestyle that encouraged her creative work as well as a partner who supported her in her creative lifestyle - making meals, hosting friends and family while Bethell was the hostess, the centre of attention.

Bethell is recognised as one of the pioneers of modern New Zealand poetry. Like others of her generation she was forced to confront the tension between her English origins and sympathies and her New Zealand milieu. In addition she was drawn to examine the disjunctions between religious certainty and everyday experience. Her attempts at developing a poetic voice to express her enlarged understanding were bold and innovative; in all her observations she looked with new eyes.

In a letter to Holcroft, Bethell described the relationship with Pollen as 'prevailingly maternal' - a bond of mutual protection and support. She also expressed similar views to fellow poet John Summers and theatre director Rodney Kennedy. Whiteford (2008) contends that it has become increasingly common in recent years to interpret the relationship between the two women as lesbian; Bethell's description of it as 'prevailingly maternal' is read, if not as a deliberate subterfuge, then as a way of explaining physical tenderness between women.

Whatever the nature of their relationship, Pollen's death further affected Bethell in that it made it almost impossible for her to write any further poetry. Whiteford states that Bethell confessed in a letter to Eileen Duggan: 
Time and Place ... is made up of things written about the same time as the Garden pieces - in the same burst of excitement - of joy. ... Now I am a tree struck by lightning - dead. I can think things, but not feel them. One must feel to write. All joy is lost ... As I wander about these mountain roads I try to pray, and to know that prayers are heard when they seem not to be. It is all pain ... \& a sense of failure $-\mathrm{I}$ am told that purgatory begins in this world ... You know I think one has to write about anything - out of faith - great poets may write out of great grief but faith must impel the little ones. If I could find that again - or even a lively hope instead of a faint one! (Bethell in Whiteford, 2008: no pagination).

There is, of course, no way of knowing for certain what was the nature of the relationship between the two women, and the question is complicated by the debate over whether the term 'lesbian' should be applied only to sexual relationships or more generally to social, celibate relationships.

Her personal life may always be a mystery but there is no question that her primary emotional and intimate life was with another woman. She came through that pain and grief to once again create new work and to be acknowledged by her peers as a strong force in New Zealand's literary history. However, for many years, and for some modern critics, Bethell's work has not been regarded as lesbian writing.

\section{Eve Langley}

One very interesting example of a woman writer whose career covers the whole time period of this thesis and who chose to live an unconventional literary life was Eve Langley. Australian by birth she came to live in Northcote, New Zealand, where she became friends with Gloria Rawlinson, Hyde and Sargeson. The alternative life she lived as a man does not necessarily mean that Langley was lesbian, but she was certainly an alternative thinker. She was known to have affairs with women and wrote about it in her poetry and fiction. Langley worked as a journalist, a travelling bookseller, and then a gardener and housemaid at a hostel in Whanganui. Around 1934 she moved to Carterton, where she met Luigi Rinaldi, a car salesman. In 1935 at Auckland she had his child (who died shortly after 
birth). Afterwards she met an art student, Hilary Roy Clark, whom she married in 1937. Although 32, she gave her age as 28; he was 22. The couple were to have three children.

During the 1930s Langley had begun writing poetry and short stories, and these were widely published in New Zealand periodicals. In 1938 Hyde wrote, 'Eve Langley ... has colour and a swift imagery, which changes shape in her exotic mind without effort or strain'. (Hyde in McLeod, 2007: no pagination) In 1940, while living in extreme poverty with two small children on Auckland's North Shore she wrote her first novel, The Pea Pickers. It is based on her and her sister June's experiences as cross-dressing itinerant farm labourers (Steve and Blue) in Gippsland in the late 1920s.

In 1954 Angus and Robertson, the Australian publishers of The Pea Pickers, published its sequel, White Topee. In a short episode Eve/Steve tells an Italian cobber that she is really Oscar Wilde reborn as a woman. That year Langley claimed that she had changed her name by deed poll to Oscar Wilde. Angus and Robertson refused to publish her next novel, Wild Australia, where a Wilde narrative takes over the last third of the novel. This intriguing obsession dominates Joy L. Thwaite's 1989 biography of Langely.

After the rejection of Wild Australia, Langley set two more novels in Australia and based her others on the journals she had kept since her arrival in New Zealand. They are, like The Pea Pickers, first-person narratives beginning with Eve/Steve's arrival in New Zealand and ending in 1941 when she has two children and is pregnant again. The readers for Angus and Robertson rejected the 10 novels written by Langley in the 1950s and 1960s as 'purely personal' and as showing a 'most insensitive lack of reticence in her private affairs'. Thus, these Australian publishers are shown to have the same reluctance to use the 'personal experience' as a valid literary device, and as discussed in the chapter on women poets, ignore the 'female' impetus in literature.

McLeod states, however, that this is what gives the novels a powerful and fascinating insight into a disastrous marriage and the conflict Langley experienced between her responsibilities as a wife and mother and her attempted career as a writer. A friend of Robin Hyde and Gloria Rawlinson, 
and an observer of the Elam art scene, she provides glimpses in her unpublished novels of the bohemian literary and artistic fringes of Auckland, as well as vivid portrayals of places and buildings, such as Partington's Mill, where as a student her lover, Hilary, had a room. The unpublished typescripts of Langely's novels are held in the Mitchell Library, Sydney.

Langley died alone, sometime between 1-13 June 1974, in a cottage at North Katoomba in the Blue Mountains, where her body was found about a month later. Ruth Park in her 1992 autobiography, A Fence around the Cuckoo writes of meeting Langley in 1940:

a dazzling autodidact with a head full of classical literature, other languages, and uncontrollable creativity the frustration of which was eventually to drive her mad; ... to me she was a living example of all that was rapturous, exciting, literary (Park in McLeod, 2007: no pagination).

Again, Langley's work is seldom read as 'lesbian writing' nor is this lens used to interpret her writing.

\section{Jane Mander}

Novelist Jane Mander died in 1949. She is known primarily for her novel, The Story of a New Zealand River. The furore over the themes of love and sexuality that this book focused on shocked the parochial small town sensibilities of the New Zealand literary scene and her work was not well treated at the time. This novel was set in the lush bush clad surroundings of this area and evokes the author's love of nature. Her father was one of the early entrepreneurs in North Auckland and after running the mill he tried his hand at politics and the press, buying the Northern Advocate newspaper, which gave his daughter a chance to write - she worked as a reporter and sub-editor and eventually ran the editorial office herself.

Mander spent time in Sydney as a freelance journalist but had aspirations to study at Columbia University and at the age of 35 she sailed for New York, travelling via London, carrying with her the script of a novel 
which she offered to four publishers, all of whom declined it. At Columbia University, she achieved the highest grades in examinations at the end of her first and second years, a remarkable feat given that she also held numerous part-time jobs including lecturing, coaching younger students, and writing for magazines to supplement her income.

During this time she continued to rework her novel but after another rejection, finally abandoned it. Financial pressure and overwork exacerbated her poor health, and she was forced to abandon her studies in her third year. Known for her liberal feminism, she joined the suffrage movement in 1915 and campaigned for the New York State referendum on women's franchise. During this time she worked on a new novel, which was accepted by John Lane in 1917 and published in 1920: The Story of a New Zealand River.

While well received in England and the USA, The Story of a New Zealand River was poorly reviewed in New Zealand. Lacking precedents for a local literature, critics reproved the novel's failure to conform to the familiar conventions of the nineteenth century regional British novel in theme and content. Reviewers expected documentary literalism in a novel so liberally sprinkled with real place names and details of actual events. Many readers found the novel too outspoken on matters of sex and religion. The New Zealand Herald, in 1920, proclaimed The River's liberal ending 'too early for good public morality'; it was set aside in the 'Reserve' section of libraries to be borrowed by approved adults only on special request to the librarian.

Mander's next three novels were all set in New Zealand, drawing directly on her childhood experiences of pioneering life in the north. The Passionate Puritan (1921) is a rather cheerful account of kauri milling, apparently written with an eye on the cinema, 'a mistake', Mander claimed, she 'ever afterwards regretted' (Mander in McGregor, DNZB, 2007: no pagination). Critical attention focused on Mander's purported failure to portray convincingly 'representative' members of the communities she chose to sketch, on her putative moral deviance, and her continued obsession with what was labelled 'the sex problem'. Mander responded from London to her critics in a letter to the Auckland Star in 1924: 
a writer who is trying to be an artist, as I sincerely am, has nothing whatsoever to do with being a tourist agent, or a photographer, or a historian, or a compiler of community statistics. I am simply trying to be honest and loyal to my own experience ... as a matter of fact I'm not half sexy enough for thousands of readers here (Mander in McGregor, DNZB, 2007: no pagination).

Having championed the advances of New Zealand abroad for two decades, Mander was now bitterly disappointed in her country, which to her mind had failed to fulfil its potential and had become 'one of the backward people of the earth'. The puritanical malaise, so often attacked in her New Zealand novels, was a condition she now found rampant, threatening to dissipate the energies and promise of the pioneers. It is deeply ironical that it is precisely this puritanical, imitative colonialism, which marked the response of her original New Zealand readers to her novels. Illness, years of pedestrian literary work, and an intolerant local audience combined to whither her creativity.

Some women novelists of this time like Mander treated sexual themes far more openly and daringly than their contemporary male counterparts and often argued for 'free love'. (Laurie, 2003) For example, Jean Devanny's The Butcher's Shop in 1926 described a loveless marriage, and her heroine's extramarital relationship as 'clean', because it was motivated by love and her book was banned as a result. Hyde in The Godwits Fly in 1938 juxtaposed 'the glory hole', or sex, with 'the glorybox', or marriage: neither was satisfactory for women, but love may be worth it.

McLeod (2001) discusses lesbian readings of Mander's 1920 novel The Story of a New Zealand River and Escott's 1936 novel Showdown. The New Zealand Women's Weekly and other magazines included romance stories reinforcing the ideals of Hollywood and the belief that women should marry for love having met 'Mr Right'. These representations reinforced ideas of the 'companionate marriage', added to by love-songs played on the radio.

And McLeod suggests that there were New Zealand connections during this period of lesbian awareness in New York. For example, McLeod says that Jane Mander lived in Greenwich Village from: 
1912 near Willa Cather, affirming, 'we had something of a little set of our own in Greenwich Village'. She moved on to London in 1920, describing 'getting to know Radclyffe Hall and the Sackville Wests' before returning to New Zealand in 1934 (McLeod, 2001: 51).

Mander writes with an intimate sense of belonging to this country and a fervent love of it; her work is undistorted by either exaggerated enthusiasm or the colonial cultural cringe. From financial necessity she wrote articles, reviewed books for the Mirror and the Monocle and gave radio talks on a variety of topics.

Mander associated with literary figures not only overseas. In New Zealand she also knew other writers such as Holcroft, Sargeson, Roderick Finlayson, D'Arcy Cresswell and Hyde, and even experienced writers valued her critical appraisal of their work. In a landmark series of articles which appeared in the Christchurch Press in 1934 she advised New Zealand novelists on how to break away from the local pitfalls of too much scenery and sentiment. Her humour, her vigour, and her respect for worthwhile writing is evident in these essays and in all her journalism. She was a founding member of the PEN New Zealand Centre and honorary vice president of the New Zealand Women Writers' and Artists' Society from 1932 until her death in 1949.

Although her output is relatively small, her reputation as a novelist has grown since her death. Other contemporary writers addressed social issues in a local context, but few matched Jane Mander's technical facility, candour, and insight into personal relationships (McGregor in DNZB, 2007: website).

Her work is seldom read as lesbian writing.

\section{Katherine Mansfield}

Another woman writer to explore lesbian experiences was this country's most celebrated writer. Although she is outside my timeframe Mansfield was one of the first 'voices' of New Zealand women to represent a lifestyle that was independent, professional and creative and had a major effect on inspiring 
other New Zealand women to write what they thought and felt. She was friends with The Bloomsbury Group in London who admired the elegance of her short story writing. Yet the themes of her work took her back to her childhood and the New Zealand landscape.

During her short life she was part of the literary circles of the time including Virginia Woolf, DH Lawrence \& Frieda, who became her closest friends, and aspects of Mansfield's personality have inspired fictional characters in D. H. Lawrence's Women in love, Aldous Huxley's Point counter point, Francis Carco's Les innocents and Conrad Aiken's 'Your obituary well written'. Her long-term relationship with John Middleton-Murray led to many collaborations between the two as writers, critics and editors. However, Mansfield explored lesbian relationships in her work and had strong relationships with women throughout her life.

For example, she had a close relationship with a Māori girl who she met at school and some of her stories reflect the intimacy and eroticism of their early encounters with their burgeoning sexuality. This relationship was with Maata Mahupuku, a Māori woman Mansfield met in Wellington, and then again in London. In Mansfield's story 'Bliss' she indicates the first consciousness of unspoken feelings between women. This 'knowing' of women's intimacy was rarely written about and Mansfield was one of the first New Zealand writers to articulate a deep insight into other women's emotional and psychosexual attraction.

Mansfield wrote of passion, relationships, abandonment and emotional turmoil that resonated with a new generation of readers in New Zealand wanting to find something tangible in a culture rooted in parochialism and dominated by sport. Mansfield's literary prowess was something to hold onto. In spite of her own conviction that she would not be 'fashionable' for long Mansfield has acquired an international reputation as a writer of short stories, poetry, letters, journals and reviews, but is not mostly read as 'lesbian writing', and even stories like 'Bliss' are not generally interpreted as such. 


\section{Ngaio Marsh}

Edith Ngaio Marsh was born in Christchurch on April 23, 1895, only 45 years after the Canterbury province was founded. While still a child, the family moved to the house in Cashmere, about $700 \mathrm{~m}$ from the home of Ursula Bethell, where she lived for the rest of her life. Her talents lay in three directions; painting, the theatre, and crime fiction. Marsh remains an enigmatic figure in the annals of New Zealand women writers. On one level she is still, perhaps, the New Zealand writer best known outside this country as discussed earlier.

Yet, despite her success she appears to have felt she failed to get on terms with herself. It has been suggested that it was her sexuality that was responsible for her unease. Wevers, in a review of Joanne Drayton's (2008) biography of Marsh, writes:

The mystery of Ngaio Marsh remains unsolved. When Ngaio Marsh's autobiography Black Beech and Honeydew, first published in 1965[6], was considered for a reprint in 1980, Collins' Crime Club editor Elizabeth Walter panned the idea. She thought the original book 'pretty dull' and noted that if you are going to write an autobiography you have to be prepared to 'let your hair down a little'. Joanne Drayton's Ngaio Marsh: Her Life in Crime seems to promise that it will let something down, billing itself as 'the ultimate detective story - revealed for the first time', and featuring a chic and androgynous Marsh on its cover. But what really does it reveal? (Wevers, 2008: Nov 15-21).

Wevers points out that Drayton's big revelation is that Marsh's most significant emotional relationships were with women and may also have been sexual, is impossible to verify or make personal. Wevers concludes that while Marsh was a larger-than-life figure, whose legacy to New Zealand was considerable, it will be a 'Died in the Wool' fan who wants to absorb so much detail about her, and at the end, what will they really know that they didn't know (or guess) before?

Drayton's is not the first biography of Marsh. Margaret Lewis (1991) Ngaio Marsh: A Life, does not reveal Marsh's private life. Marsh herself comments in her autobiography that 'I have deflected my own reticence' (Marsh, 1966: 284) and she took pains to destroy evidence - every letter from her friend Doris Mclntosh, for instance. However, there is evidence that 
she certainly found expressions of the 'other' interesting, even if she was not a participant. For example, on her first visit to England in 1928, which lasted five years, she frequented London clubs and was fascinated to see:

almost always alone, at a table just inside the door, sat a strange figure: an old, old man with a flower in his coat who looked as if he had been dehydrated like a specimen leaf and then rouged a little. No one ever accompanied him or paused at his table. He looked straight before him and at intervals raised his glass in a frog's hand and touched his lips with it.

One night we asked the restaurateur who he was.

'A poet,' said Signor Vecchi, 'and once, long ago I understand, a celebrated personage. It is Lord Alfred Douglas' (Marsh, 1966: 201).

He was the lover of Oscar Wilde. On a trip to Monte Carlo, Marsh saw for the first time transvestites and transsexuals and women dressed as men on stage. She observed:

Ladies ... of a kind that was entirely new to me. The croupiers referred to the most dominant of them as 'cette monsieur-dame'. She seemed to be having quite a pleasant time of it, running her finger round inside her collar and settling her tie. She wore a sort of habit and was perhaps by Isherwood out of Huxley. The disconcerting thing about many of the habitués was their tendency to seem as if they had been written by somebody not quite on the top of his form (Marsh, 1966: 208).

Her 33 novels with her main character policeman Roderick Alleyn, who was described in a sketch she included in one manuscript, handsome but surprisingly feminine. This writing could be regarded as 'lesbian' with Alleyn as an alter-ego for herself.

In 1977 the Mystery Writers of America gave her their highest honour, naming her a Grand Master (she joked about not being a Grand Mistress). Marsh was created a Dame in 1966. And while her autobiography gives nothing away and she publicly denied being a lesbian, doubts remain. New Zealand novelist Stevan Eldred-Grigg suggests the very fact that she 'overinvented herself' is indicative. His 1997 novel Blue Blood explores the idea that she was lesbian. She was widely supposed to be lesbian on the stereotypical basis of her deep voice and her habit of wearing trousers, and 
lifelong friend, Sylvia Fox, lived in a bungalow just above her house. Analysing her work as 'lesbian writing' could bring new perspectives to Marsh's work, but is outside the scope of this thesis.

\section{Esma North and Marjory Lydia Nicholls}

Both Esma North, born in 1892, and Marjory Nicholls, born in 1891, attended Wellington Girls' College, where Nicholls edited the school magazine, and was regarded as one of the best known and best loved girls of the school. Both women became teachers and in North's case she became principal of Wellington Girls College. At Victoria University College Nicholls was the first woman to win the Plunkett Medal for oratory, produced two Drama Society plays and was active in various other groups, though did not complete a degree.

Nicholls went overseas and in England studied stage production with Edith (Edy) Craig who lived in a lesbian ménage a trois with Christopher St John and Claire (Tony) Atwood. Edith founded the Barn Theatre at Smallhythe which attracted a lesbian circle, including Radclyffe Hall, Una Troubridge, Vita Sackville-West, Winaretta (Singer) de Polignac, Ethel Smyth and other lesbian suffragists which connects Nicholls to a prominent British lesbian network (Laurie, 2003).

Back in New Zealand Nicholls studied painting with Dorothy Kate Richmond. She lived in her own flat in Sydney Street, Wellington, and was a close friend of poet Eileen Duggan who, despite being deeply religious, may also have had lesbian relationships. Nicholls published three volumes of poetry: A Venture in Verse (1917), Gathered Leaves (1922) and Thirdly (1929) and was well known in amateur theatre. She was run over at a bus stop in October 1930, dying at the age of 40 years. These two stanzas are from her poem 'A Would-be Wanderer':

Rest at an inn (if it come my way)

For l'll walk any road I please,

Chanting verse from Euripides, 
Or Villon's ballads of yesterday.

Or loll Bohemian-wise and dream

About Verlaine or Baudelaire -

A poet strange, with pea-green hair,

Who supped, o'nights, from a skull of cream

(Nicholls, 1917: 1).

It has been suggested that this poem indicates that Nicholls was familiar with both classical and French writers on homosexuality or other forms of 'other' sexual behaviour and states her resolve to live an independent life. (Laurie, 2003) Living in her own flat, studying with famous lesbians, and traveling round the world, Nicholls in her short life walked the roads she pleased.

Esma North (her name was a mixture of her first and second names, Esther and Mary) published one volume of poetry, Primroses for my Fair, in 1930. Throughout the book there are what are nowadays called markers, hints at things that may be a sub-text to any given book or philosophy. In this case it has been suggested that much of North's work contained references to lesbian or 'other' forms of relationships between women. Indeed, Wright notes of the poem 'Human Comfort' that: 'Nowadays it would be read as a lesbian poem' (Wright, 1998: 13).

Further indications of North's possibly lesbian interest can be found in some other poems. Two seem to be obvious echoes of Irish poet Oscar Wilde's relationship with Lord Alfred Douglas. One poem is called 'De Profundis', the title of a famous work by Wilde. Another Wildean echo can be found in North's poem, 'Hush! Beloved', in which each stanza there is a variation of the last three lines:

I'll speak, my sweet, In whispers low. I would not have them hear The words I breathe for my lover's ear (North, 1930:7).

While it is true that the person North addresses is not acknowledged as a man or a woman, there is, perhaps, something of the following famous line: 'I am the Love that dare not speak its name'. Lord Alfred Douglas coined the 
phrase in his poem to Wilde, Two Loves (1896). Also the phrase 'primrose path' refers to those who are dedicated to the pursuit of pleasure, another Wildean echo. Wright throws another light on this aspect by discussing the poem, 'Lady Mine', by Marjory Nicholls. He suggests:

For instance in the poem 'Lady Mine' the person addressed sounds real. The term Primrose-like and the account of a compassionate conservationalist read to me as a very definite reference to Esma North (Wright, 2009: 8).

Wright mentions a poem by Nicholls called 'Little Daughter' which he claims:

Clearly tells the story of a young woman whose love affair has had a bitter outcome. By 1911 Marjory Nicholls was 20 years old ... don't rule anything out (Wright, 2009: 13).

So whether Nicholls and North were lesbian lovers as young women in either a strict or open definition of the term cannot be ruled out. While there is no definitive biographical evidence the speculation is valid given the circumstantial and literary evidence.

That both Nicholls and North were seen as being of the much vilified 'Georgian School' by the writers and publishers whose views took precedence in the late 1930s has meant that their obscurity in the New Zealand literary canon since that time was assured; that they were also women added to their being marginalised. The main reason that the majority of the women I have written on lesbian writers fall outside my time frame, 1945 to 1970 , is because that it was only women writing on either side of the years mentioned who wrote with any openness about their lives in the sexual sense. This is quite understandable when we observe some of the male attitudes prevalent at the time, manifested by Fairburn who wrote feminists:

have so bedevilled the man-woman situation that only the most arrant sentimentalist is likely to be applauded. Any writer who tries to import a little common sense into that situation is asking to be lynched by the moustached Amazons of the women's journals and the millions who abide by their word. (Fairburn, 1967: 22-23) 
Like many women writers of the period 1945-1970 women writing about lesbian matters hid their thoughts and feelings. The fact that women were writers at all was often seen in a disparaging and condescending way by both male writers and publishers. Add to that the 'perversion' of deviant sexual practices and they must have feared a double rejection slip in the mail. No writers felt comfortable with this subject matter until after this period, and for those who did write on such topics the lesbianism was either ignored, as in Mansfield's 'Bliss', or the work was not regarded as significant, as in North's poems.

Thus, while there is not much evidence of lesbian writing available during the period of this study there is a likelihood that women writers who were 'lesbian' did not want to openly express their sexual and emotional preference for fear of being ridiculed and ostracised by those in the literary scene and in society as a whole. The next chapter is about a genre that many in the literary world have considered a woman's domain, that of writing for children. I argue that the politics of who and what got published in this field often mirrors the male dominated area of the other literary traditions covered thus far in this thesis, for example the School Journal.

\footnotetext{
${ }^{1}$ James Courage's The Fifth Child (1948) and A Way of Love (1959) have homosexual themes, as do several of Frank Sargeson's pre-1970s stories - 'The hole that Jack dug', 'I for one', 'I saw in my dream', 'I've lost my pal' and 'That summer'.

${ }^{2}$ See Appendix 13 for full interview.

${ }^{3}$ It is interesting to note that Effie Pollen is buried about 200 yards from the poet Marjory Nicholls in Wellington's Karori Cemetery.
} 


\section{Chapter 10}

\section{Children's Writers}

This chapter considers the women writers who wrote children's stories. I look at the career of Elsie Locke, and discuss how the School Journal and the Publications sector of the Department of Education gave a significant forum for many of the writers who later went on to be among our better-known writers. The chapter also looks at how the School Journal, for example, encouraged writers like Frame when she was a child in Oamaru to want to become a writer herself. It allowed her, and others like her, to believe that such a thing was possible, even in New Zealand.

Anyone studying The Oxford Companion to New Zealand Literature for children's literature between 1945 and 1970 by either men or women writers could be forgiven for thinking that little or nothing existed in this genre during those years. There are two entries on literature for children in the book, firstly an article titled 'Children's pages' by Heather Murray that concerns itself with New Zealand newspapers which had exclusive pages set aside for children's interests. This entry names some of these papers from the 1870 s through to the 1940s when 'paper shortages during World War 2 curtailed or ended many children's features and radio gave children another option for entertainment' (Murray, 1998: 104).

The only two other children specific entries in the companion are no more than a paragraph each. The 'New Zealand Children's Literature Association' (NZCLA) was formed in 1969 to provide a 'grass-roots' approach to introduce children to books and other literature. Secondly, there is the 'New Zealand Children's Book Foundation' (Te Maataa Pukapuka Tamariki o Aotearoa) that was established in 1990 as a part of the New Zealand Book Council to promote children's books, and encourage reading by children. Of course, this does not tell the whole story and many of the women writers who appear in this thesis began their careers writing for the children's pages in daily newspapers. Murray writes: 'When books for the young were not widely available, early exposure to writing encouraged children to feel part of a lively 
writing community, in which Hyde, Dallas, Frame, Ruth Park, Locke and others first achieved publication' (Murray, 1998: 103). In some of the individual entries of writers in The Oxford Companion to New Zealand Literature the work of the writers is acknowledged in the field of writing for children.

\section{Early reading inspires writing}

And it was not just publication as adults that these book pages encouraged, but also as children some of these writers attributed the fact that newspaper children pages existed that was the reason they could entertain the notion to become writers themselves. For example, Frame in 1936, then at the age of twelve, states in volume one of her autobiography that she along with others began 'to write their own poems and stories, encouraged locally by the children's pages in the newspapers' (Frame, 1991: 78).

In Sturm (1998) there is slightly more coverage of Children's literature, with a whole chapter dedicated to this genre. There is a sub-heading 'New Impulses, 1950-1970' which deals with the children's writing of the period of this thesis except for the years 1945 to 1950 . Betty Gilderdale, who wrote the entry on children's literature, sees two main trends in books for children during this period. One is a push to establish a literature that focuses on developing New Zealand's own national identity through a literary move towards 'social realism', that is a an acknowledgement of experience of life in New Zealand as it is lived by people who live here.

\section{Washday at the Pā}

The second was the increase in books depicting Māori themes and people in a more positive, less idealized context. For example, Gilderdale states that the writers and publishers of the time aimed 'not only to show "life in New Zealand" on farm, on sea shore, and in the high country, but also to offer positive images of the Māori' (Gilderdale, 1998: 540). Jane Hill, Gay Kohlap, 
Pat Lawson and Valerie Salt were all involved in this sub-genre of children's writing. Ans Westra, in an interview in the September 1964 issue of 'Photography' (quoted in Gilderdale's entry), about her controversial photographic essay Washday at the Pā, which was withdrawn from distribution as a 1961 School Bulletin on the grounds that it gave the wrong impression of Māori people, her aim was to show 'what an intelligent coloured race can do with civilization when they are given a chance by being treated as human beings' (Westra, 1998: 540).

Not withstanding the unintentional racism inherent in a phrase like 'an intelligent coloured race' Westra's approach in depicting a Māori community in a photo-journalistic manner was certainly new and challenging. Westra herself was, of course, a woman artist and writer whose work broke new ground in terms of women undertaking the kind of work she was doing since she moved to New Zealand from Europe in 1957. She was also something of a pioneer in her subject matter of showing the everyday lives of ordinary New Zealanders, and in particular using Māori and Pacific Island subjects for her photographic essays long before they became common currency.

Her early work appeared in many magazines such as $\mathrm{Te}$ Ao Hou and much of her work was for the Department of Education. It is perhaps ironic that despite her seemingly enlightened approach to Māori motifs, which often highlighted the women's roles in whānau life that the harshest criticism of her Washday at the Pā book came from the Māori Women's Welfare League. Gregory O'Brien in A Nest of Singing Birds tells of further Westra works around this time. He says she also produced 'book-length photo-essays for the [School] Journal, including Children at Play and Holiday in the Capital (both 1964) and The Circus Comes to Town (1965). The latter publication was an extended piece of accessible photojournalism although, as was the case with much of Westra's commissioned work, there were some remarkable pictures amidst the workaday ones' (O'Brien, 2007: 125). 


\section{Elsie Locke}

It could be said what Westra was doing with her camera the writer Elsie Locke was doing with her pen. Locke (1912- 2001) ${ }^{1}$ was a writer, novelist, historian and leader in peace movements and women's affairs, and another writer whose life covers the whole time-frame of this study. Born in Hamilton, Locke described the hardships and delights of her early life in Waiuku and at Auckland University in her autobiographical work Student at the Gates (1981).

This autobiography details life in the 1920s-30s, illuminating both some dominant political and literary personalities of the time and also the influences which shaped her idealistic socialist philosophies. In the 1930s Locke edited the early feminist journal Woman Today (Hebley, 1998: 309).

Born Elsie Farelly, in 1941 she married Jack Locke, both having been members of the New Zealand Communist Party, which she left in 1956 after the Russian invasion of Hungary. They moved from Wellington to Christchurch, where they raised four children. She served on the national executive of the Campaign for Nuclear Disarmament (1957-70). She also continued writing for adults: The Shepherd and the Scullery Maid (1950), The Human Conveyer Belt (1968), The Gaoler (1978) on early Otago, and two privately printed family histories. She edited Gordon Watson, New Zealander, 1912-1945 (1949). In 1959, she received the Katherine Mansfield Award for Non-Fiction for her essay in Landfall 48.

Locke is probably more widely known as a writer for children. Drawing her topics and themes from her interests and commitments, she carried out diligent research, often historical or relating to outdoor exercise. Her preparation included learning Te Reo Māori to understand the Māori point of view, which she expresses with sympathy and insight in novels that in this respect were in advance of general perceptions. Her first novel for children was based on a true story. The Runaway Settlers (1965), illustrated by Anthony Maitland, portrays a remarkable historical-fiction mother whose experiences include driving a herd of cattle over the Southern Alps and down 
the Teremakau River to the West Coast. This novel has been in continuous print for longer than any other New Zealand children's book.

Locke's historical novels during the period covered by this thesis include The End of the Harbour (1969), illustrated by Katarina Mataira, a compassionate exploration of land issues from Māori and Pākehā perspectives. Of Locke's books Gilderdale states they are 'closer, perhaps, to historical documentary than to fiction. They present Māori perspectives and are based on careful reconstructions of actual events, angled from the viewpoint of a young protagonist' (Gilderdale, 1998: 545).

The 1951 New Zealand Writers' Conference was part of Canterbury's Centenary celebrations, for which Locke had written The Shepherd and the Scullery Maid. She had also published a number of articles and poems by this time, and several of her radio talks had been broadcast. The Conference was held in Christchurch in May 1951, and Elsie was one of the few women there. Ruth France, another Canterbury woman writer, who was married to a boat-builder, also attended, but it wasn't until after the Conference that she and Locke became friends.

One day, France approached Locke in the Christchurch Public Library and told her quite frankly that she was 'starved for literary conversation'. Both had children, both had been librarians, and both were inspired to commemorate the 1951 Wellington to Lyttelton boat race, which was devastated by a violent storm. Locke wrote For Those Who Sailed, a series of poems, and France wrote a novel, The Race, published in 1958. Sometimes France wrote under the pen name Paul Henderson. France's own life suggests a degree of frustration:

Determined to be the good wife and mother that society at the time demanded, she also spoke of the impulse towards writing, of the intensity of purpose that grew with age and excluded procrastination, and of the happiness of being alone and writing (Beaglehole, 2007: DNZB website).

Although France did not write for children the two women must have found much common ground in their lives' circumstances as they shared the double 
balancing act of bringing up children as well as being writers. France predeceased Locke by thirty-three years, dying in 1968 from cancer.

At the conference, Locke sat with Winston and Sophie Rhodes. Winston taught English at the university and often lectured for the Workers Education Association (WEA). Locke reported on the Conference in the left-wing journal Here and Now the following month, declaring 'The Conference confirmed that our native literature has outgrown its knobbly-kneed stage, and has the vigour of youth, if not the quality of maturity.' She expressed special gratitude for James K Baxter's address on 'Recent Trends in New Zealand Poetry' for its wisdom, its penetration, its social awareness, and its superbly phrased language.

She also mentioned addresses by Johannes $C$ Anderson on Māori Lore; by Blackwood Paul on 'The Novel in New Zealand' and by H Winston Rhodes on William Morris and his 'art for the people and by the people.' At the end of her report, she 'unashamedly' added a footnote about the social responsibility of writers:

I am convinced that many writers find it difficult because they begin with themselves instead of with the other fellow ... The Conference revealed that, potentially at least, many of those present have much to give, even though their skill at the craft is not yet matched by their understanding of crucial human problems ... Will they succeed in cultivating and conveying the life-giving spiritual food which a young country needs at this grave yet dazzlingly hopeful point in history? (Locke, 1951: 27-28).

Locke had her first contribution to the School Journal, 'the Secret Rescue', published in 1958, and thereafter became a regular contributor until her death in 2001. During the intervening years she wrote many articles which reflected her commitment to social and socialist ideas. This can best be seen in her article in the Part 4 School Journal 1968, a year designated as the United Nations' 'Human Rights Year'. The issue had an interesting cover by artist David Cowe and was titled 'The Hopeful Peace \& the Hopeful War', which echoed her 1951 article on the Writers' Convention. In the 1968 School Journal Locke states: 
Everyone has the right to food, clothing, housing and social services ... No one shall be held in slavery or servitude ... Everyone is entitled to these rights and freedoms without distinction of sex ... Everyone has the right to freedom of thought, conscience and religion; to freedom of speech and opinion, and of peaceful assembly and association (Locke, 2007: 58).

Thus Locke enters into her children's canon the ideas and ideals of her political and social agenda. To emphasise that 'everyone is entitled to these rights and freedoms without distinction of sex' in an official 'journal' aimed at eleven and twelve year olds was quite a brave and unusual thing to do in 1968.

\section{The School Journal}

While the School Journal was a good outlet for New Zealand artists and writers as a place or forum to earn money by their talents, it also was a predominately male-orientated affair at least until the 1970s. For example, until 1972 when Vanya Lowry took over as editor and 'embraced the new possibilities [of technology and design] and pushed the limits' (O'Brien, 2007: 30 ), the editors were male and most of the permanent staff were also men. It is a common assumption that the majority of writers and artists in the children's literature genre are women.

However, an analysis of those who were either writing for or illustrating for the School Journal from its inception in 1907 and its centenary in 2007 shows that men were the most numerically represented. Thus, in its first one hundred years out of the two hundred and ninety nine artists and or writers 168 men and 131 were women, as presented in the index of the recent history of the School Journal, A Nest of Singing Bird.' The most famous period of literary editorship of the School Journal is perhaps the 1950s and 1960s when the main editor was poet Alistair Te Ariki Campbell, with the other three poets James K Baxter, Louis Johnson, and Peter Bland making a formidable foursome of the cream of New Zealand literature at the time. 
While many women writers and artists, such as Ruth Dallas, Ruth Park, Evelyn Clouston and Jill McDonald, (and some like Joan Smith and Helen Shaw produced both writing and artwork) at the time were given commissioned work to do for the Journal, and the men above had a reputation for being sympathetic towards women writers a lot of the time, ${ }^{2}$ the fact remained that these men were the arbiters of taste and the ones who had the say in what and who got published.

Alongside the School Journal the Department of Education also commissioned and produced the school Bulletins which were single issue publications that allowed for social studies, geography and historical topics to be explored by children at greater length than could be done in the Journal. These sometimes became quite controversial, as in the Bulletin titled 'Te Tiriti o Waitangi' by Ruth Ross, that challenged the then orthodox position on the Treaty of Waitangi. So, it may be said that while some of the women writers at the time of 1950s and 1960s were at the forefront of social and political change such as Māori and women's rights issues, the fact of who and what was published was still controlled by male writers, editors and publishers.

\footnotetext{
${ }^{1}$ See Appendix Number 5 for Locke's bibliography. This information was given to me by Locke's biographer, Maureen Birchfield, whose book Looking for Answers: $A$ Life of Elsie Locke, was published by Canterbury University Press in September 2009.

${ }^{2}$ This was not always the case. See for example the dispute and correspondence over Louis Johnson's review of Ruth Gilbert's work in Numbers 7 between Johnson and Willow Macky in the chapter on 'Women Poets' in this thesis.
} 


\section{Chapter 11}

\section{Conclusion}

This thesis on women writers between 1945 and 1970 in New Zealand has examined the evidence on whether they were deliberately under-represented and their work trivialised by the male writers and publishers of the time. I contend that I have established such under-representation and trivialisation. However, it is interesting to note that women novelists of the time were treated differently by their male counterparts than women poets. The former were, in the main, ignored in the literary world, while the latter were treated with a mixture of disdain and hostility.

While the evidence I have presented shows that several women novelists and writers of fiction were often highly successful in terms of commercial sales, that this did not translate into respect and acceptance in the literary world, with the exception of Janet Frame, who had early in her career shown great literary promise as acknowledged by Sargeson in an influential article in the NZ Listener, April 1952. Also in 1952 her first book, The Lagoon and Other Stories, won the Hubert Church Memorial award: 'the country's major literary award for prose ... To those "in the know", it represented a prestigious honour' (King, 2000: 112). Apart from authors like Mary Scott and Joyce West, who were both extremely popular and widely read within New Zealand, most of the successful women of the period had very popular and lucrative careers outside New Zealand. The bibliographical appendices I present with this thesis illustrate this in graphic detail.

As previously discussed, it was in 1930 when the anthology Kowhai Gold was published, its editor, Quentin Pope, expressed the hope that its contents might serve as the foundation of a New Zealand literature. However, within a few years the anthology was seen as the embodiment of an outmoded tradition of versifying, dominated by female poets. The verses were depicted as sentimental and clichéd, and Curnow characterised it as a 'lamentable anthology [in which] imported insipidities were mixed with puerilities of local origin'. This attitude appears to have been given its first 
expression in in 1934 with Glover and Milner's small but influential anthology, New Poems. Between this and Curnow's anthology of 1945 a 'masculinist' momentum seems to have gathered pace, helped in part by the advent of the Second World War and its aftermath. For around this time a largely male, secular group of younger poets and critics, attracted by Modernist forms and philosophies, became influential.

The career of poet Eileen Duggan can be seen as a key example of the fate of many New Zealand women poets and writers during the period covered by this thesis. Prominent among the poets included in Kowhai Gold was Duggan, who until then had a high reputation. Internationally, her poetry continued to be well received, but in New Zealand her standing began to wane, and never recovered. Duggan's subsequent absence from major anthologies was as a result of her own decision, but it was a decision she felt forced to make by the prejudice and animosity she encountered. During the 1920 s and the early 1930s, Duggan was beginning to understand the importance of a national literature for New Zealand - an understanding that, ironically, is not dissimilar from that of the nationalist poets who later condemned her work.

In using the example of Duggan from before the beginning of the period under study, there appears to be a progression of negative thought, words and deeds through to the 1970s regarding the treatment of women writers by their male counterparts. Even after 1970 the pattern of omission continued. For example, in 1972 a new self-styled 'revolutionary' poetry periodical began. In first issue of Lipsync were '36 New Poems by New Zealand's Leading Writers' (Andrews \& Pasley, 1972). However, of the 25 poets represented only two were women, Joan Shirley-Thompson and Riemke Ensing. The evidence I have presented in the individual chapters of this thesis and the appendices that accompany them show a definite trend, and at times specific deliberate examples, of male indifference and at times malevolence directed towards female subjects, sensibilities and styles of writing as well as individual women writers themselves.

As discussed in the chapter on the literary background to this thesis, it was Curnow's following of T.S. Eliot's 'ban on the personal' that represented 
a fundamental difference between male and female writing. This became what was essentially a difference between the Georgian and Modernist philosophies of literary thought, with Curnow representing the Modernist school of thought as it manifested itself as an anti-female movement within New Zealand literature. Appreciation of women's writing was to surface in gender-specific feminist publications such as Broadsheet together with writing by women academics like Wevers and McLeod. However, the majority of these critiques only appeared after the period covered by my thesis, although Joan Stevens at least mentioned Romance writing in her work, if somewhat disparagingly. In the 1980s critics like Terry Sturm made a reappraisal of some of the women writers such as Rosemary Rees.

I noted in my chapter on Methodology that women were considered Other not because they are numerically less in number than the dominant group, but because of their sex alone. Indeed, one of the objectives of this thesis is to facilitate debate in relation to the women writers of the 1945 to 1970 period in New Zealand and how they might be considered in terms of their Otherness to New Zealand male writers of the time. It is in the words of the women writers themselves that the most compelling evidence can be found. The poet Ruth Gilbert is recorded in a 1967 interview on the male response to women writers:

I think most male reviewers approach a piece of writing differently when they see a woman's name on it. They unconsciously patronise. A writer wants to be recognised as a writer, not as a man or a woman. But even when a woman writer becomes known, she is not the male writer's equal (Gilbert in 'Sketch' Wright, 2007: 17-18).

It will be remembered that Gilbert wrote of poet and editor Louis Johnson that she would have to change her sex for Johnson to fully accept her as a writer, and Willow Macky suggested that women had felt they had to ape men 'Monkey-like' in order to be taken seriously. Later in the 1960s and 1970s women would take over their own affairs in relation to publishing and promoting their own work. However, even when this happened there seemed little hope of women's work being accepted in mainstream literary annals. Lesbian poet Heather McPherson (2007) echoes Gilbert's remarks by 
recalling the early 1970s. When asked what her place in New Zealand literature might be, she states: 'By the New Zealand literary scene? It could be surprising to be acknowledged at all, given some of the hostile editorialising at the time' (McPherson, 2007: 120). In the 1970s, women writers and artists began to set up their own publishing and distribution.

This attempt at autonomy can be seen in the presses founded during the drive by members of the women's liberation movement to give the new breed of women writers a voice independent of the patriarchy. A question raised by this thesis is the role played by the New Zealand Women Writers' Society in relation to why they did not establish their own publishing house in order to publish and distribute books beyond their 1953 anthology, POEMS. Why did they need a 'patron' like Pat Lawlor, why did they need a man to write the foreword to their volume? They all appear to be reasonably well off, well educated, middle class women so what stopped them from setting up an autonomous publishing house such as would be the case of women in the 1970s and beyond. Research on the lives of the members and their circumstances and work could be the subject of another study beyond the scope of the present thesis.

In discussing the factors accounting for the under-representation and trivialization of women writers of my period, I have explored the social and historical context for women, including the impact of WW2, and outlined the careers of a number of women poets and novelists, including some detailed case studies. I have also examined the particular issues facing Māori and lesbian writers. I conclude that a supportive and encouraging environment was rarely available for women writers from 1945 to 1970, that most struggled to be published and appreciated, and that only later, if at all, with the progress of second wave feminism, were many of these important writers properly recognised.

I have throughout used the ideas of inclusion and diversity inherent in my understanding of what was required to reflect both the underlying philosophy of both the feminist methodologies and the Gender and Women's Studies Department. Thus I have used a multitude of concepts and research methods. While this approach may have its limitations of throwing the net too 
widely, I have from the outset stated that I wanted to provide an overview of the period I had chosen to write on, and to provide a starting point for further study by providing bibliographical and biographical material that may be difficult to otherwise access. If I have achieved this then my work has been well worth the effort.

Thus, this thesis has explored the constraints that delayed and inhibited the work of a gifted generation of women writers, some of whom were recognised in the post-1970s period after second wave had successfully removed some of the barriers to women's full participation in the cultural life of New Zealand. Through examining the detail of selected writers' lives, it is possible to understand how their exclusion was systemic rather than individual, and how the prevailing structures of sexism, racism, classism and homophobia worked to normalise the prototypical great New Zealand writer of the period as invariably male, white, middle-class, and preferably with direct experience of bloody and violent war service that could become significant material for his poetry and prose.

The leading writers, publishers, and critics of the 1945-70 period operated in the shadow of WW2, developing and clinging to attitudes that successfully excluded women writers from the literary canon and it is in this context that binarism is important. The fact that the male writers, publishers and critics, in effect, set up an 'us and them' situation with regard to gender, or more to the point an 'us and don't worry about them' leads to any discussion on the period as being binary by nature.

This thesis has been a long learning curve for me. It has been an honour to work with the many people who have helped me. When I started out I had an idea that, as I have said, grew out of my MA thesis on small press publishing. It has always been my ambition as a writer, artist, publisher, and academic to contribute to the cultural wealth of New Zealand/Aotearoa. I also have a keen feeling for righting injustice, and this was one of the driving forces behind my wanting to investigate the topic chosen. Like all investigations of this nature much of what I found was quite surprising.

One of the most interesting things was the successes of the women novelists of the period. The fact that much of that success was experienced 
overseas and that women like Ngaio Marsh felt shunned by her homeland is significant. Looking at the bibliographies of Dorothy Eden and Dorothy Quentin gives a great insight into the success of these two novelists. The number of languages they were translated into and their commercial success are all significantly undermined by the lack of critical acclaim here. Dismissed as either 'Crime Writers' or 'Romance Writers', these women were not considered real writers. Even Rosemary Rees described herself in selfdeprecating tones as 'the highest paid author in New Zealand' as though it was something to be ashamed of rather than celebrated.

However, it has been the attitudes to women poets of the period that has really made my thesis worthwhile for me. To find out how badly they were treated by their male counterparts was quite shocking. I have over the years had the privilege to work with many women poets, either at poetry readings or in my capacity as a publisher. We have always treated each other with mutual respect and I have always considered their work in the same way I have treated the male poets I have published. Therefore, I hope that this thesis is used as an inspiration for further investigation in more detail about the issues raised and the poets written about in this sketch.

My conclusion to this thesis must be one of regret, that the New Zealand readers were largely denied the pleasure of reading several of these writers until a later period, that New Zealand literature was not influenced by their work until later, and the writers themselves experienced so many hardships and difficulties before their work was recognised, if at all. I conclude this thesis by reference again to 'Judith' Shakespeare. In the words of Virginia Woolf:

... Shakespeare had a sister ... she died young - alas! She never wrote a word ... she lives in you and me, and in many other women who are not here tonight, for they are washing up the dishes and putting the children to bed. But she lives; for great poets do not die; they are continuing presences ... the opportunity will come and the dead poet who was Shakespeare's sister will put on the body which she has so often laid down ... when she is born again she shall find it possible to live and write her poetry ... (Woolf, 2000: 148-149). 


\section{BIBLIOGRAPHY (Based on Chicago Style Guide, 15 $5^{\text {th }}$ Edition)}

Adcock, Fleur. 'Comment'. In Riemke Ensing, ed. Private Gardens: An Anthology of New Zealand Women Poets. Dunedin: Caveman Press, 1977.

Adcock, Fleur. 'Elegy for Alistair'. In 'New Zealand Books: a Quarterly'. Vol. 19, no. 4, Issue 88, Summer (2009).

Aitken, Judith. A Woman's Place: a Study of the Changing Role of Women in New Zealand. Auckland: Heinemann Educational Books, 1975.

Aldridge, Alexandra, and Marthalee Barton, eds. 'Alternative Futures: Women and the Future,' The Journal of Utopian Studies 4, nos. 2-3, Spring/Summer (1981).

Alley, Elizabeth, ed. The Inward Sun: Celebrating the Life and Work of Janet Frame. Wellington: Daphne Brassell Associates Press, 1994.

Andrews, Isobel. [ed. Ian A. Gordon] 'The Day of the Funeral'. In New Zealand New Writing: No. 2. Wellington: Progressive Publishing Society, [c1940s].

Andrews, Peter \& Rhys Pasley, eds. Lypsync No.1. Wellington: Andrews \& Pasley, 1972.

Annabell, Angela. http://folksong.org.New Zealand.poatarau/index

Anon. 'Janet Frame Bibliography': www.nlf.auckland.ac.New Zealand

Anon. 'Janet Frame Bibliography': www.janetframe.org.New Zealand

Anon. http://rpo.library.utoronto.ca/poet/537.html [Ruth Gilbert on-line]

Anon. 'Māori Writer wins Major Award'. Te Ao Hou. December, 1959, No. 29: 4

Anon. New Zealand Literature: Author's Week 1936, Annals of New Zealand Literature. Wellington: New Zealand Author's Week Committee, 1936.

Anon. New Zealand Weekly News, $3^{\text {rd }}$ of Sept 1958. 
Anon. 'The Māori Contribution to New Zealand Literature'. Te Ao Hou. 1973 No. 71: 36, 37.

Anon: The Mirror. Auckland: April, 1957.

Anon. 'Tuini Ngawai'. Te Ao Hou. No. 14, April 1956: 46.

Anon. 'Tuini Ngawai Memorial Hui'. Te Ao Hou. No. 55, June, 1966: 38.

Ashcroft, Bill, Gareth Griffiths, and Helen Tiffin. The Empire Writes Back: Theory and Practice in Post-Colonial Literatures. London: Routledge, 1989.

Ashton-Warner, Sylvia. Spinster. London: Secker \& Warburg, 1958.

Ashton-Warner, Sylvia. [Whenua: letters of Sylvia Ashton-Warner to Ruth Gilbert. Letter $\# 1$ - 28.4.1967].

Bagnall, A.G., P.A. Griffith, and K.S. Williams, eds. New Zealand National Bibliography: To The Year 1960. Wellington: Government Printer, 1980.

Barrowman, Rachel. A Popular Vision: The Arts and the Left in New Zealand 19301950. Wellington: Victoria University Press, 1991.

Baxter, James K. 'Mazeppa' - unpublished poem: c1950s. (see endnote [ii] in 'Chapter 4 Literary Background'.)

Baxter, James K. The Fire and the Anvil. Wellington: New Zealand University Press, 1957.

Baxter, James K. The Man on the Horse. Dunedin: University of Otago Press, 1967.

Baxter, James K. Autumn Testament. Wellington: Price Milburn, 1974.

Baysting, Arthur, [ed]. The Young New Zealand Poets. Auckland: Heinemann Educational Books, 1973.

Beaglehole, Helen. 'France, Helena Ruth, 1913 - 1968'. Dictionary of New Zealand Biography, updated 22 June 2007. URL: www.DNZB.govt.New Zealand 
Bebbington, W.G. [ed]. Introducing Modern Poetry: An Anthology. London: Faber \& Faber, 1944.

Bennet, Elsie. In Sandra Coney. Every Girl: A Social History of Women and the YWCA in Auckland. Auckland: YWCA, 1986.

Bergmann, Laurel. 'Where to from here? Contemporary New Zealand Women's Fiction.' Hecate Vol. 20, Issue 2, (1994): 213-215.

Bernikow, Louise, [ed]. The World Split Open: Four Centuries of Women Poets in England and America 1552-1950. London: The Women's Press, 1974.

Bethell, Ursula. In Allen Curnow [ed]. A Book of New Zealand Verse. Christchurch: Caxton Press, 1951.

Bethell, Ursula. In Peter Whiteford. 'Ursula Bethell, 1874-1945'. In Millar, Paul, Jane Stafford \& Mark Williams, eds. Kotare 2008. Special Issue - Essays in New Zealand Literary Biography Series Three: 'The Early Poets.' www.New Zealandetc.org/tm/scholarly/tei-Whi073Kota

Birchfield, Maureen. Looking for Answers: A Life of Elsie Locke. Christchurch: Canterbury University Press, 2009.

Blain, Virginia \& Isobel Grundy \& Patricia Clements, eds. The Feminist Companion to Literature in English. New Haven: Yale University Press, 1990.

Boddy, Gillian. 'Mansfield, Katherine 1888 - 1923'. Dictionary of New Zealand Biography, updated 22 June 2007. URL: www.DNZB.govt.New Zealand

Bonner, Frances, Lizbeth Goodman, Richard Allen, Linda Janes, and Catherine King, eds. Imagining Women. Cambridge, UK: Polity Press, 1995.

Boraman, Toby. Rabble Rousers and Merry Pranksters: a History of Anarchism in Aotearoa/New Zealand from the Mid 1950s to the Early 1980s. Christchurch/Wellington: Katipo Books and Irrecuperable Press, 2007.

Bordo, S. 'The Cartesian Masculinisation of Thought'. Signs 11, 3 (1986) 439 - 456. 
Bornholdt, Jenny and Gregory O'Brien, [eds]. My Heart Goes Swimming: New Zealand Love Poems. Auckland: Godwit, 2000.

Bowden, Simon. 'Manhire poem makes it into the New Yorker'. www.stuff.co.New Zealand/ entertainment/ books/3173499

Brasch, Charles, [ed]. Landfall Country: Work from Landfall 1947-61 chosen by Charles Brasch: Stories, Poems, Essays, Paintings. Christchurch: The Caxton Press, 1962.

Brasch, Charles. The Universal Dance: A Selection from the Critical Prose Writings of Charles Brasch. Dunedin: University of Otago Press, 1981.

Brookes, Barbara, Charlotte Macdonald, and Margaret Tennant, eds. Women in History: Essays on European Women in New Zealand. Wellington: Allen \& Unwin/Port Nicholson Press, 1986.

Broughton, W.S. A.R.D. Fairburn. Wellington: A.H. \& A.W. Reed, 1968.

Brunton, Alan. Years Ago Today: Language \& Performance: 1969. Wellington: Bumper Books, 1997.

Brunton, Alan, Murray Edmond, and Michele Leggott, eds. Big Smoke: New Zealand Poems 1960-1975. Auckland: Auckland University Press, 2000.

Buck, Claire, ed. Bloomsbury Guide to Women's Literature. London: Bloomsbury Publishing, 1992.

Bunkle, Phillida, and Beryl Hughes, eds. Women in New Zealand Society. Sydney: Allen \& Unwin, 1980.

Burgess, Grace. A Gentle Poet: A Portrait of Eileen Duggan, O.B.E. Masterton: Grace Burgess, 1981.

Burns, James. A Century of New Zealand Novels: A bibliography of the period 18611960. Auckland: Whitcombe \& Tombs, 1961. 
Burns, James. New Zealand Novels and Novelists 1861-1979: an Annotated Bibliography. Auckland: Heinemann Publishers, 1981.

Butterworth, Karen Peterson. Fluid. Paekakariki: Earl of Seacliff Art Workshop, 2006.

Butterworth, Karen Peterson. My Affair with Words. (unpublished 'work in progress' memoir: given to me by the author - Karen Peterson Butterworth, 2010).

Cadman, Eileen, Gail Chester, Agnes Pivot. Rolling Our Own: Women as Printers, Publishers and Distributors. London: Minority Press Group, 1981.

Campbell, Alistair Te Ariki. In Stead, C.K. In the Glass Case: Essays on New Zealand Literature. Auckland: Auckland University Press with Oxford University Press, 1981.

Campbell, Alistair Te Ariki. The Dark Lord of Savaiki: Collected Poems. Christchurch: Hazard Press, 2005.

Campbell, Alistair Te Ariki \& Meg Campbell. It's Love, Isn't It? The Love Poems. Wellington: HeadworX, 2008.

Campbell, Helen. Mary Lambie: A Biography. Wellington: The New Zealand Nursing and Research Foundation, 1976.

Campbell, Meg. Resistance. Paekakariki: Earl of Seacliff Art Workshop, 2005.

Campbell, Meg. In Deborah Shepard [ed]. Between the Lives: Partners in Art. Auckland: Auckland University Press, 2005.

Castle, Terry. In Alison Laurie, Lady-Husbands and Kamp Ladies: Pre-1970 Lesbian Life in Aotearoa/New Zealand. PhD. Thesis. Wellington: Victoria University, 2003.

Caute, David. Fanon. London: Fontana/Collins, 1970.

Challis, Derek, and Gloria Rawlinson. The Book of Iris: A Biography of Robin Hyde. Auckland: Auckland University Press, 2002. 
Chapman, Robert, and Jonathon Bennett, [eds]. An Anthology of New Zealand Verse. London: Oxford University Press, 1956.

Cixous, Hèléne. In Elaine Showalter, ed. The New Feminist Criticism: Essays on Women, Literature, and Theory. New York: Pantheon Books, 1985.

Clarke, Isabel C. Katherine Mansfield: a Biography. Wellington: The Beltane Book Bureau, 1944.

Condliffe, J.B. The Welfare State in New Zealand. London: George Allen \& Unwin, 1959.

Coney, Sandra, et al, [eds]. United Women's Convention: Report. Auckland: W.E.A., 1973.

Coney, Sandra. Every Girl: A Social History of Women and the YWCA in Auckland. Auckland: YWCA, 1986.

Coney, Sandra. Standing in the Sunshine: a History of New Zealand Women Since They Won the Vote. Auckland: Viking, 1993.

Contreras, Alan. www.bgleasondesign.com/crane2/books.htm [Cameron La Follette]

Cook, Blanche Wiesen. In Lady-Husbands and Kamp Ladies: Pre-1970 Lesbian Life in Aotearoa/New Zealand. PhD. Thesis. Wellington: Victoria University, 2003.

Cox, Shelagh, [ed]. Public \& Private Worlds: Women in Contemporary New Zealand. Wellington: Allen \& Unwin/Port Nicholson Press, 1987.

Curnow, Allen, [ed]. A Book of New Zealand Verse 1923-1945. Christchurch: The Caxton Press, 1945.

Curnow, Allen, [ed]. A Book of New Zealand Verse 1923-1950. Christchurch: The Caxton Press, 1951.

Curnow, Allen. In R.A.K. Mason, Collected Poems. Christchurch: Pegasus Press, 1963.

Curnow, Allen, ed. The Penguin Book of New Zealand Verse. Auckland: Penguin Books with Blackwood \& Janet Paul, 1966. 
Curnow, Allen. Look Back Harder: Critical Writings 1935-1984, Peter Simpson, ed. Auckland: AUP, 1987.

Curnow, Allen. In Kai Jensen. Whole Men: the Masculinist Tradition in New Zealand Literature. Auckland: Auckland University Press, 1996.

Curnow, Wystan, ed. Essays on New Zealand Literature. Auckland: Heinemann Educational Books, 1973.

Cvitanovich, Lynley: Breaking the Silence: Protest in the Feminist Fiction of Two New Zealand Women Writers. Jean Devanny, 1894-1962 and Edith Searle Grossman, 1863-1931. MA Thesis, Sociology. Palmerston North: Massey University, 1984.

Dale, W.S. In 'Literature in New Zealand' The Bookman [London] Vol.77 no.461, Feb.1930.

Dallas, Ruth. Curved Horizon: An Autobiography. Dunedin: University of Otago Press, 1991.

Dalziel, Margaret. Janet Frame. Wellington: Oxford University, 1980.

Dann, Christine. Up from Under: Women and Liberation in New Zealand 1970-1985. Wellington: Port Nicholson Press, 1985.

Davin, Dan. Not Here, Not Now. Auckland: Whitcombe \& Tombs, 1970.

Davin, Dan. Closing Times. Auckland: OUP, 1985.

de Beauvoir, S. The Second Sex. New York: Alfred Knopf, 1952.de la Mare, Walter. In Eileen Duggan, introduction. Poems. London: Allen and Unwin, 1937.

de Montalk, Count Potocki. Recollections of My Fellow Poets. Auckland: Prometheus Press, 1983. 
Diaz; Angeli R. 'Postcolonial Theory and the Third Wave Agenda.' Women and Language Vol. 26, (2003).

Douglas, Lord Alfred and Oscar Wilde. www.phrases.org.uk/meanings/364900

Douglas, N.V, Chairman. Women's Rights Committee: June 1975. Wellington: Government Printer, 1975.

Drabble, Margaret, ed. The Oxford Companion to English Literature. Oxford: Oxford University Press, 1996.

Drayton, Joanne. Ngaio Marsh: Her Life in Crime. Auckland: HarperCollins, 2008.

'Dreams, John, O', ed. Gift Book of New Zealand Verse. Wellington: N.Z. Radio Publishing Company, undated.

Du Chateau, Robyn. In Tolerton, Jane. 60s Chicks hit the nineties. Auckland: Penguin Books, 1997.

Duggan, Eileen. Poems. London: Allen \& Unwin, 1937.

Duggan, Eileen. More Poems. London: Allen \& Unwin, 1951.

Dunlop, Alan R., ed. Poems: Anthology by New Zealand Women Writers. Invercargill: New Zealand Women Writers and Artists' Society, 1953.

Eagleton, Terry. Marxism and Literary Critism. London: Methuen \& Co, 1985.

Eden, Dorothy. In The Mirror. London: [newspaper] 1957.

Edmond, Lauris, ed. Women in Wartime: New Zealand Women Tell Their Story. Wellington: Government Printing Office Publishing, 1986.

Edwards, Brian. Helen: Portrait of a Prime Minister. Auckland: Exisle Publishing, 2001.

Edwards, Mihi. Mihipeka: Early Years. Auckland: Penguin Books, 1990.

Eldred-Grigg, Stevan. Blue Blood. Auckland: Penguin Books, 1997. 
Ell, Sarah, ed. The Lives of Pioneer Women in New Zealand: From Their Letters, Diaries and Reminiscences. Auckland: The Bush Press, 1993.

Else, Anne. 'Not More Than Man Nor Less.' Landfall 156, Vol. 39 no. 4 (1985).

Else, Anne, ed. Women Together: A History of Women's Organisations in New Zealand, Ngā Ropü Wāhine ö te Motu. Wellington: Historical Branch, Department of Internal Affairs, Daphne Brasell Associates Press, 1993.

Else, Anne: On Shifting Ground. PhD. Thesis. Wellington: Victoria University, 2006.

Ensing, Riemke, ed. Private Gardens: An Anthology of New Zealand Women Poets. Dunedin: Caveman Press, 1977.

Evans, Marian, Bridie Lonie, and Tilly Lloyd, eds. A Women's Picture Book: 25 Women Artists of Aotearoa (New Zealand). Wellington: GP Books, 1988.

Evans, Patrick. The Penguin History of New Zealand Literature. Auckland: Penguin Books, 1990.

Evans, Patrick. Dr. Clutha's Book of the World: Janet Paterson Frame, 1924-2004. Journal of New Zealand Literature, 22, 2004, http://www.engl.canterbury.ac.New Zealand/research /pde3.htm

Evans, Patrick. The Long Forgetting: Post-colonial literary culture in New Zealand. Christchurch: Canterbury University Press, 2007.

Faderman, Lillian. In Lady-Husbands and Kamp Ladies: Pre-1970 Lesbian Life in Aotearoa/New Zealand. PhD. Thesis. Wellington: Victoria University, 2003.

Fairburn, A.R.D. The Woman Problem and Other Prose. Auckland: Paul, 1967.

Fairburn, A.R.D. Collected Poems. Christchurch: Pegasus Press, 1967.

Fairburn, A.R.D. In Lauris Edmond ed. The Letters of A.R.D. Fairburn. Auckland: Oxford University Press, 1981. 
Fairburn, A.R.D. In Denys Trussell Fairburn. Auckland: AUP/OUP, 1984.

Faludi, Susan. Backlash: the Undeclared War Against Women. London: Chatto \& Windus, 1992.

Forster, John, ed. Social Process in New Zealand: Readings in Sociology. Auckland: Longman Paul, 1969.

Frame, Janet. In Hayward, Margaret \& Joy Cowley, eds. Women Writers of New Zealand 1932-1982. Wellington: N.Z. Women Writers' Society/Colonial Associates, 1982.

Frame, Janet. Janet Frame: An Autobiography. Auckland: Random Century, 1991.

Frame, Janet. Toward Another Summer. Auckland: Vintage, 2007.

Frame, Janet. Faces in the Water. London: Virago Modern Classics, 2009.

France, Thelma, Hestia Quinn, Roma Henden, and Isobelle Ashforht, eds. History of New Zealand Women Writers' Society 1932-1982. Wellington: New Zealand Women Writers' Society, 1982.

Fyfe, Judith, ed. Matriarchs: A Generation of New Zealand Women Talk to Judith Fyfe. Auckland: Penguin Books, 1990.

Gamman, Lorraine, and Margaret Marshment, eds. The Female Gaze: Women as Viewers of Popular Culture. Seattle: The Real Comet Press, 1989.

Gibbs, Rowan. Dorothy Quentin: A La Recherche De La Madeleine Perdue: a Bibliographical Romance. Te Aro, Wellington: Original Books, 2005.

Gibbs, Rowan, and Richard Williams. Ngaio Marsh: A Bibliography. Scunthorpe, U.K., 1990. www.ngaio-marsh.org.New Zealand/biblio

Gilbert, Ruth. In Yearbook of the Arts in New Zealand. Christchurch: Pegasus Press, 1948.

Gilbert, Ruth. Collected Poems. Wellington: Black Robin, 1984. 
Gilbert, Ruth. Early Poems: 1938-1944. Wellington: Cultural and Political Booklets, 1988.

Gilbert, Ruth. In Among Friends of the Author: a bibliographical romance as resource book for scholars of Aotearoa poetry. Te Aro, Wellington: Cultural and Political Booklets, 2007.

Gilbert, Ruth. In Sketch Profile of Ruth Gilbert with Full Commentary: Quoting Various Authors, a compilation. Te Aro, Wellington: Cultural and Political Booklets, 2007.

Gilbert, Sandra M. In Elaine Showalter, ed. The New Feminist Criticism: Essays on Women, Literature and Theory. New York: Pantheon Books, 1985.

Gilderdale, Betty. In Terry Sturm, ed. The Oxford History of New Zealand Literature in English. Auckland, New Zealand: Oxford University Press, 1998.

Gilson, M. In John Forster, ed. Social Process in New Zealand: Readings in Sociology. Auckland: Longman Paul, 1969.

Glover, Denis \& lan Milner, eds. New Poems. [Christchurch]: The Caxton Club Press, 1934.

Glover, Denis. Hot Water Sailor and Landlubber Ho! Auckland: Collins, 1981.

Glover, Denis. Selected Poems. Auckland: Penguin, 1981.

Glover, Denis. In Kai Jensen Whole Men: the Masculinist Tradition in New Zealand Literature. Auckland: Auckland University Press, 1996.

Glover, Rupert, ed. Strawberry Fields: Arts Festival Poetry Yearbook. Christchurch: University of Canterbury Students' Association, 1967.

Gluck, Shema Berger. Rosie the Riveter Revisited: Women, the War and Social Change. New York: Meridian/New American Library, 1988.

Goldin, Claudia. Understanding the Gender Gap: An Economic History of American Women. New York: Oxford University Press, 1990. 
Gordon, Pamela. 'Janet on the Planet', 2009 [blog]. Website: janetframe.org.New Zealand

Gormack, Bob. In Waite, Noel. In Griffith, Penelope, Peter Hughes \& Alan Loney eds. A Book in the Hand. Auckland: Auckland University Press, 2000.

Grant, Linda. In 'introduction' to Janet Frame's: Living in the Maniototo. London: Virago Press, 2009.

Griffith, Penelope, Peter Hughes \& Alan Loney eds. A Book in the Hand. Auckland: Auckland University Press, 2000.

Hall, Leslie M (pseudonym for Phoebe Meikle). In 'Women and Men in New Zealand'. Landfall 12, Vol. 1, 1958.

Hamer, Emily. In Lady-Husbands and Kamp Ladies: Pre-1970 Lesbian Life in Aotearoa/New Zealand. PhD. Thesis. Wellington: Victoria University, 2003.

Hardy, Linda. Landfall 156, Vol. 39 no. 4 (1985): 400.

Harris, Nancy. 'Baughan, Blanche Edith 1870 - 1958'. Dictionary of New Zealand Biography. updated 22 June 2007. URL: www.DNZB.govt.New Zealand

Harvey, Siobhan [ed]. In Poetry New Zealand 39. Brick Row Publishing: Auckland, New Zealand /Palm Springs, California, USA, 2009.

Hawke, G.R. The Making of New Zealand: VUW Working Papers in Economic History 81/3, (Reprint with Minor Corrections). Wellington: Victoria University of Wellington, 1982. 
Hawes, Tara. 'Janet Frame: The Self as Other/Othering the Self'. Deep South v.1 n.1 (Otago University English Dept., February, 1995).

Hayward, Margaret \& Joy Cowley, eds. Women Writers of New Zealand 1932-1982. Wellington: N.Z. Women Writers' Society/Colonial Associates, 1982.

Hebley, Diane. In Robinson, Roger, and Nelson Wattie, eds. The Oxford Companion to New Zealand Literature. Auckland: Oxford University Press, 1998.

Heilbrun, Carolyn G. Writing a Woman's Life. New York: W.W. Norton, 1988.

Heim, Otto. Writing Along Broken Lines: Violence and Ethnicity in Contemporary Māori Fiction. Auckland: Auckland University Press, 1998.

Hilliard, Chris. The Bookman's Dominion: Cultural Life in New Zealand 1920-1950. Auckland: Auckland University Press, 2006.

Holcroft, M.H. Reluctant Editor: the Listener Years, 1949-1967. Wellington: Reed, 1969.

Holcroft, M.H. Mary Ursula Bethell. Wellington: Oxford University Press, 1975.

Holman, Jeffrey Paparoa. 'Jacqueline Sturm: A Pioneering Literary Figure'. www.stuff. co.New Zealand/dominion-post/national/obituaries

Hood, Lynley. Sylvia!: The Biography of Sylvia Ashton-Warner. Auckland: Viking, 1988.

Hughes, Beryl, and Sheila Ahern. Redbrick and Bluestockings: Women at Victoria 18991993. Wellington: Victoria University Press, 1993.

Hyde, Robin. [i.e. Iris Wilkinson] Journalese. Auckland: The National Printing Co. Ltd., 1934.

Hyde, Robin. In Allen Curnow, ed. The Penguin Book of New Zealand Verse. Auckland: Penguin Books with Blackwood \& Janet Paul, 1966.

Hyman, Prue. Women and Economics: a New Zealand Feminist Perspective. Wellington: Bridget Williams Books, 1994. 
Ihimaera, Witi. 'N.Z. Listener', 17 March, 1984.

Isaac, Peter. 'Dorothy Eden's unfulfilled ambition' New Zealand Bookworld 19 (Oct.-Nov. 1975).

James, Bev \& Kay Saville-Smith. Gender, Culture \& Power. Auckland: Oxford University Press, 1994.

Jensen, Kai. Whole Men: the Masculinist Tradition in New Zealand Literature. Auckland: Auckland University Press, 1996.

Johnson, Louis, ed. 'numbers seven'. Wellington: Literary Review: 1957, p28.

Johnson, Louis, ed. New Zealand Poetry Yearbook '64: Volume 11. Christchurch: Pegasus Press, 1964.

Johnson, Olive. A.R.D. Fairburn, 1904-1957, A Bibliography of his Published Work. Auckland: Auckland University Monograph Series No. 3, 1958.

Johnston, Jill. In Lady-Husbands and Kamp Ladies: Pre-1970 Lesbian Life in Aotearoa/New Zealand. PhD. Thesis. Wellington: Victoria University, 2003.

Jones, Alison. 'Writing Feminist Educational Research: Am 'l' in the text.' In Women and Education in Aotearoa 2, edited by Sue Middleton and Alison Jones. Wellington: Bridget Williams Books, 1992.

Jones, Lawrence. In Kai Jensen. Whole Men: the Masculinist Tradition in New Zealand Literature. Auckland: Auckland University Press, 1996.

Jones, Lawrence. In Terry Sturm, ed. The Oxford History of New Zealand Literature in English. Auckland: Oxford University Press, 1998.

Jones, Lawrence. In Griffith, Penelope, Peter Hughes \& Alan Loney eds. A Book in the Hand. Auckland: Auckland University Press, 2000.

Jones, Lawrence. In 'Kite 22'. Dunedin: The New Zealand Literature Association [newsletter], May, 2002. 
Jong, Erica. In Joanna Russ. How to Suppress Women's Writing. London: The Women's Press, 1984.

Kennedy, Rodney. In Deborah Shepard, ed. Between the Lives: Partners in Art. Auckland: Auckland University Press, 2005.

Kessler-Harris, Alice. A Woman's Wage: Historical Meanings and Social Consequences. Lexington: University Press of Kentucky, 1990.

King, Michael. Wrestling with the Angel: a Life of Janet Frame. Auckland: Viking, 2000.

King, Michael. The Penguin History of New Zealand. Auckland: Viking, 2004.

King, Michael J. In E. Fuller Torrey. The Roots of Treason: Ezra Pound and the Secrets of St Elizabeths. London: Sidgwick \& Jackson, 1984.

Kizer, Carolyn. In Carolyn G Heilbrun. Writing a Woman's Life. New York: W.W. Norton, 1988.

Klein, Renate. In 'Feminist Multiple Methods Research.' Feminist Methods in Social Research, by Shulamit Reinharz. Oxford, UK: Oxford University Press, 1992.

Koza, Kimberley Ann. Women as Images of History: Contemporary Anglophone Fiction by Minority and Post-colonial Women Writers. PhD. Thesis. Indiana: Indiana University, 1988.

La Follette, Cameron. From personal correspondence with Rowan Gibbs and Niel Wright, December, 2008.

Laura, Valerie. 'Bethell, Mary Ursula 1874 - 1945'. Dictionary of New Zealand Biography, updated 22 June 2007 URL: http://www.DNZB.govt.New Zealand/

Laurie, Alison J. 'Katherine Mansfield - A Lesbian Writer?', In The Women's Studies Journal. Vol. 4, No. 2, December 1988.

Laurie, Alison J., ed. Lesbian Studies in Aotearoa/New Zealand. New York: Harrington Park Press, 2001. 
Laurie, Alison J. Lady-Husbands and Kamp Ladies: Pre-1970 Lesbian Life in Aotearoa/New Zealand. PhD. Thesis. Wellington: Victoria University, 2003.

Lawlor, Pat. In Robinson, Roger, and Nelson Wattie, eds. The Oxford Companion to New Zealand Literature. Auckland: Oxford University Press, 1998.

Lee, Elizabeth. Women in Literature. www.victorianweb.org/gender/womlitcov

Lennon, John and Yoko Ono. 'Woman is the nigger of the world'. Sometime in New York City. [Record Lyric Sheet]. London: Apple, 1972.

Letherby, Gayle. Feminist Research in Theory and Practice. Philadelphia: Open University Press, 2003.

Lewis, Margaret. Ngaio Marsh: A Life. Wellington: Bridget Williams Books, 1991.

Lewis, Margaret. In Bernie Steeds. 'Mysterious double Life of Dame Ngaio Marsh.' Evening Post, April 151995.

Locke, Elsie. 'Writers in Conference' Here and Now. 1, no 9, June 1951.

Locke, Elsie. 'Is There an Answer Without Religion' Here \& Now. 1, no 11/12, August, 1951.

Locke, Elsie. In Gregory O'Brien. A Nest of Singing Birds: 100 Years of the New Zealand School Journal. Wellington: Learning Media, 2007.

Locke, Terry, [ed]. Jewels in the Water: Contemporary New Zealand poetry for younger readers. Hamilton: Leaders Press, 2000.

Locke, Terry, ed. Doors: a Contemporary New Zealand Poetry Selection. Hamilton: Leaders Press, 2000.

Lovell-Smith, Margaret, ed. The Woman Question: Writings by the Women who Won the Vote. Auckland: New Women's Press, 1992. 
Macdonald, Charlotte, Merimeri Penfold, Bridget Williams, eds. The Book of New Zealand Women: Ko Kui Ma Te Kaupapa. Wellington: Bridget Williams Books, 1992.

Mackay, Diedre. 'Profile of the Poet Ruth Gilbert'. Nelson: Nelson Mail, February 1991.

MacKay, Jessie. Land of the Morning. Christchurch: Whitcombe and Tombs, 1909.

Mackenzie, Joy. In Deborah Shepard, ed. Between the Lives: Partners in Art. Auckland: Auckland University Press, 2005.

Mackersey, Ian. Jean Batten: The Garbo of the Skies. Auckland: Macdonald Publishers (New Zealand) Ltd, 1990.

Macky, Willow. 'Controversy: The Critic on the Mat.' numbers, New Zealand quarterly of new writing, no.7 (1957): 26-29.

Maconie, Janet. Landmarks of New Zealand Writing to 1945. Wellington: New Zealand Book Council, 1990.

Mansfield, Katherine. 'Leves Amores'. http://www.gayNewZealand.net.New Zealand/history/LevesAmores

Mantel, Hilary. 'The Guardian', July $12^{\text {th }}$ 2008.www.theguardian.co.uk/theguardian /2008/jul/12/guardianreview

Mantel, Hilary. In Janet Frame. Faces in the Water. London: Virago Modern Classics, 2009.

Marris, C.A., ed. New Zealand Best Poems of 1933. Wellington: Harry H. Tombs, 1933.

Marris, C.A., ed. New Zealand Best Poems of 1934. Wellington: Harry H. Tombs, 1934.

Marris, C.A., ed. New Zealand Best Poems of 1936. Wellington: Harry H. Tombs, 1936.

Marris, C.A., ed. New Zealand Best Poems of 1937. Wellington: Harry H. Tombs, 1937.

Marris, C.A., ed. New Zealand Best Poems of 1938. Wellington: Harry H. Tombs, 1938. 
Marris, C.A., ed. New Zealand Best Poems of 1941. Wellington: Harry H. Tombs, 1941.

Marris, C.A. In Dr. F.W. Nielsen Wright. Sketch Profile of Ruth Gilbert with Full Commentary: Quoting Various Authors. Te Aro, Wellington: Cultural and Political Booklets, 2007.

Marsh, Ngaio. Black Beech and Honeydew: An Autobiography. London: Collins, 1966.

Mason, Bruce. New Zealand Drama: A Parade of Forms and a History. Wellington: New Zealand University Press, 1973.

Matthews, Jacqueline. 'Hyde, Robin 1906 - 1939'. Dictionary of New Zealand Biography, updated 22 June 2007. URL: http://www.DNZB.govt.New Zealand

Maynard, Mary and June Purvis, eds. Researching Women's Lives from a Feminist Perspective. London: Taylor \& Francis, 1994.

McAlpine, Rachel, ed. The Passionate Pen: New Zealand's Romance Writers talk to Rachel McAlpine. Christchurch: Hazard Press, 1998.

McCahon, Colin. Rita: Seven Poems by Colin McCahon. Wellington/Auckland: Fernbank Studio/The Holloway Press, 2001.

McGregor, Rae. The Story of a New Zealand writer : Jane Mander. Dunedin: University of Otago Press, 1998.

McGregor, Rae. 'Mander, Mary Jane 1877 - 1949'. Dictionary of New Zealand Biography, updated 22 June 2007. URL: http://www.DNZB.govt.New Zealand

McKay, Frank. New Zealand Poetry: An introduction through the discussion of selected poems. Wellington: New Zealand University Press/Price Milburn, 1970.

McLeod, Aorewa, ed. New Women's Fiction. Auckland: New Women's Press, 1988.

McLeod, Aorewa. 'New Zealand's Lost Lesbian Writers and Artists.' In Lesbian Studies in Aotearoa/New Zealand, edited by Alison J. Laurie, 49-62. New York: Harrington Park Press, 2001. 
McLeod, Aorewa. 'Langley, Eve Maria. 1904 - 1974'. Dictionary of New Zealand Biography, updated 22 June 2007. URL: http://www.DNZB.govt.New Zealand

McNaughton, Trudie, ed. In Deadly Earnest: A Collection of Fiction by New Zealand Women 1870s-1980s. Auckland: Century Hutchinson, 1989.

McPherson, Heather, Julie King, Marian Evans and Pamela Gerrish Nunn, Eds. Spiral 7: A Collection of Lesbian Art and Writing from Aotearoa/New Zealand. Christchurch: Spiral, 1992.

McPherson, Heather. Travel and other compulsions. Paekakariki: Earl of Seacliff Art Workshop, 2004.

McPherson, Heather. 'Spiral Collective.' In Alternative Small Press Publishing in New Zealand: an Introduction, with Particular Reference to the Years 1969-1999, by Michael O'Leary, 116-120. Wellington: Steele Roberts, 2007.

McQueen, Harvey. The New Place. Wellington: Victoria University Press, 1993.

McRae, Jane. In Terry Sturm, ed. The Oxford History of New Zealand Literature in English. Auckland: Oxford University Press, 1998.

Meikle, Phoebe. Accidental Life. Auckland: Auckland University Press, 1994.

Mill, Patricia. In 'Life is what you make it' Woman's Choice [Auckland] 3 no.34 (Aug. 1957) pp.11, 20.

Millar, Paul. In Deborah Shepard, ed. Between the Lives: Partners in Art. Auckland: Auckland University Press, 2005.

Millar, Paul \& Aorewa McLeod. In 'J.C. Sturm'. Robinson, Roger, and Nelson Wattie, eds. The Oxford Companion to New Zealand Literature. Auckland: Oxford University Press, 1998.

Mitcalfe, Barry. Poetry of the Māori: (translations). Hamilton: Paul's Book Arcade, 1961. 
Morris, Paul, Harry Rickets and Mike Grimshaw, eds. 'Spirit Abroad: A Second Anthology of New Zealand Spiritual Verse'. Auckland: Godwit/RandomHouse, 2004.

Mulgan, Alan. Literature and Authorship in New Zealand. London: George Allen \& Unwin Ltd, 1943.

Mulgan, Alan. Great Days in New Zealand Writing. Wellington: A.H. \& A.W. Reed, 1962.

Murchie, Erihapeti. From personal papers shown to Michael O'Leary by her husband Malcolm Murchie: her taonga was gathered together by the kaitiaki of her work, Fiona Murchie.

Murphy, Rosalie, ed: with a pref. by C. Day Lewis. Contemporary Poets of the English Language. Chicago: St. James Press, 1970.

Murray, Heather. 'New Zealand Writers' Conference, 1951.' In Roger Robinson and Nelson Wattie, eds. The Oxford Companion to New Zealand Literature. Auckland: Oxford University Press, 1998.

Murray, Heather. 'Children's Pages.' In Roger Robinson and Nelson Wattie eds. The Oxford Companion to New Zealand Literature. Auckland: Oxford University Press, 1998.

Murray, Stuart. Never a Soul at Home: New Zealand Literary Nationalism and the 1930s. Wellington: Victoria University Press, 1998.

Myers, Virginia. Head \& Shoulders: Successful New Zealand Women Talk to Virginia Myers. Auckland: Penguin Books, 1987.

Needham, John. 'Recent Poetry and Coleridgean Principles'. The Journal of New Zealand Literature, \#3. Wellington: Department of English, Victoria University, 1985.

Nicholls, Marjory Lydia. A Venture in Verse. Wellington: Whitcombe and Tombs, 1917.

Nicholls, Marjory Lydia. Gathered Leaves. Wellington: Whitcombe and Tombs, 1922. 
Nicholls, Marjory Lydia. Thirdly. Wellington: [Private, Harry H Tombs, 1929/30].

Nola, Nina. 'My two countries firmly under my feet: exploration of multi-cultural identity in the fiction of Amelia Batistich and Yvonne du Fresne'. PhD. Thesis. Auckland: Auckland University.

Nolan, Melanie. Bread Winning: New Zealand women and the state. Christchurch: Canterbury University Press, 2000.

O'Brien, Gregory. A Nest of Singing Birds: 100 Years of the New Zealand School Journal. Wellington: Learning Media, 2007.

O'Donnell, Margaret J, ed. Anthology of Commonwealth Verse. London: Blackie, 1963.

O'Leary, Michael, ed. Wrapper. Seacliff: Earl of Seacliff Art Workshop, 1992.

O'Leary, Michael. The Irish Annals of New Zealand. Wellington: ESAW [Celtic typeface edition], 1997.

O'Leary, Michael. Alternative Small Press Publishing in New Zealand: an Introduction, with Particular Reference to the Years 1969-1999. Wellington: Steele Roberts, 2007.

Oliver, W.H. Poetry in New Zealand. Wellington: School Publications Branch, Department of Education, 1960.

Oliver, W.H. Looking for the Phoenix: a memoir. Wellington: Bridget Williams Books, 2002.

Onlywomen Press. In Cadman, Eileen, Gail Chester, Agnes Pivot. Rolling Our Own: Women as Printers, Publishers and Distributors. London: Minority Press Group, 1981.

Ono, Yoko. 'Sisters o sisters'. Sometime in New York City. [Record Lyric Sheet]. London: Apple, 1972.

Orbell, Margaret, ed. Contemporary Māori Writing. Wellington: A.H. \& A.W. Reed, 1974. 
O'Sullivan, Vincent, ed. An Anthology of Twentieth-Century New Zealand Poetry. London: Oxford University Press, 1970.

O'Sullivan, Vincent. New Zealand Poetry in the Sixties. Wellington: School Publications Branch, Department of Education, 1973.

Oxford English Reference Dictionary. Oxford, UK: Oxford University Press, 1996.

Page, Dorothy, 'Women and Nationality: Feminist Organisations in the Inter-war Period. In Barbara Brookes, Charlotte Macdonald, and Margaret Tennant, eds. Women in History: Essays on European Women in New Zealand. Wellington: Allen \& Unwin/Port Nicholson Press, 1986.

Park, Iris M. New Zealand Periodicals of Literary Interest. Wellington: National Library Service, 1962.

Paterson, Alistair, ed. 15 Contemporary New Zealand Poets. Dunedin: Pilgrims South Press, 1980.

Pearson, Bill. 'Fretful Sleepers'. In Charles Brasch, ed. Landfall Country. Christchurch: The Caxton Press, 1962.

Perry, Stuart, ed. The New Zealand Writer's Handbook. Wellington: A.H. \& A.W. Reed, 1952.

Pewhairangi, Ngoi. Tuini: Her Life and Her Songs. Gisborne: Te Rau Press, 1985.

Phillips, Jock. In 'Of Verandahs and Fish and Chips and Footie on Saturday Afternoon: Reflections on 100 years of New Zealand Historiography'. NZ Journal of History, October 1990, 24 (2): 118-134.

Phillips, Jock. A Man's Country? The Image of the Pākehā Male, A History. Auckland: Penguin Books, 1996.

Phillips, Jock. 'Men, Women and Leisure Since the Second World War'. In Caroline Daley and Deborah Montgomerie, eds. The Gender Kiwi. Auckland: Auckland University Press, 1999: 213-234. 
Pirie, Mark, ed. The Earl is in ... 25 Years of the Earl of Seacliff. Paekakariki: Earl of Seacliff Art Workshop, 2009.

Pollitt, Katha. In Jennifer Saul. Feminism: Issues and Arguments. New York: Oxford University Press, 2003.

Pope, Quentin, ed. Kowhai Gold: An Anthology of Contemporary New Zealand Verse. London: J.M. Dent, 1930.

Pound, Ezra, In E. Fuller Torrey. The Roots of Treason: Ezra Pound and the Secrets of St Elizabeth's. London: Sidgwick \& Jackson, 1984.

Proctor, Ellen A. A Brief Memoir of Christina G. Rossetti. London: S.P.C.K., 1895.

Quentin, Dorothy. In The Mirror. London: [newspaper] July \& August 1941.

Quentin, Dorothy. In Terry Sturm, ed. The Oxford History of New Zealand Literature in English. Auckland: Oxford University Press, 1998.

Radicalesbians. In Alison Laurie, Lady-Husbands and Kamp Ladies: Pre-1970 Lesbian Life in Aotearoa/New Zealand. PhD. Thesis. Wellington: Victoria University, 2003.

Radway, Janice. Reading the Romance. North Carolina: The University of North Carolina Press, 1984.

Radway, Janice. "Reading Reading the Romance." In Studies in Culture: An introductory Reader, ed. Ann Gray and Jim McGuigan. London: Arnold, 1997, pp. 62-79.

Reeves, James, ed. Georgian Poetry. Harmondsworth: Penguin Books, 1962.

Reeves, Trevor. 'A Survey of Recent New Zealand Writing.' Ariel: A Review of International English Literature Vol. 5, no. 3 (1974): 16 - 37.

Reid, J.C. Creative Writing in New Zealand: A Brief Critical History. Auckland: Whitcombe and Tombs, 1946. 
Reinharz, Shulamit, with Lynn Davidman. Feminist Methods in Social Research. New York: Oxford University Press, 1992.

Renée. From personal correspondence with Michael O'Leary, 2/2/2010.

Rhodes, H. Winston and Denis Glover, [eds.] Verse Alive: number two. Christchurch: The Caxton Press, 1937.

Rhodes, H. Winston. 'On Swearing'. In Rachel Barrowman. A Popular Vision: The Arts and the Left in New Zealand 1930-1950. Wellington: Victoria University Press, 1991.

Rich, Adrienne. Diving into the Wreck: Poems 1971-1972. New York: W.W. Norton, 1973.

Rich, Adrienne: 'Credo of a Passionate Skeptic.' Los Angeles Times, Sunday March 11, 2001. www.english.illinois.edu/maps/poets/m_r/rich/onlineessays.htm

Rich, Adrienne. What is Found There: Notebooks on Poetry and Politics. New York, W.W. Norton \& Company, 2003.

Rich, Adrienne: http://www.adriennerich.hpg.ig.com.br/resources.htm

Rich, Adrienne. In Alison Laurie, Lady-Husbands and Kamp Ladies: Pre-1970 Lesbian Life in Aotearoa/New Zealand. PhD. Thesis. Wellington: Victoria University, 2003.

Richmond, Mary E. Late Harvest. Te Aro, Wellington: Original Books, 2007.

Rickerby, Helen. 'Where there would Otherwise be Silence - Feminist Publishing Evading the Gatekeepers.' Endnotes (2001): 38-42.

Roberts, Heather. In The Book of New Zealand Women: Ko Kui Ma Te Kaupapa. Charlotte Macdonald, Merimeri Penfold and Bridget Williams, eds. Wellington: Bridget Williams Books, 1992.

Roberts, Heather. 'Mackay, Jessie 1864 - 1938'. Dictionary of New Zealand Biography, updated 22 June 2007. URL: http://www.DNZB.govt.New Zealand/ 
Roberts, Helen, ed. Doing Feminist Research. London: Routledge \& Kegan Paul, 1982.

Robinson, Roger, and Nelson Wattie, eds. The Oxford Companion to New Zealand Literature. Auckland: Oxford University Press, 1998.

Rose, Tim. 'Broken Journey'. (Television documentary). In www.Throng.co.New Zealand/ documentary / broken-journey-the-life-and-art-of-jc-sturm: no pagination

Rowbotham, Sheila. Hidden from History: 300 Years of Women's Oppression and the Fight Against It. London: Pluto Press, 1974.

Royal, Charles. In Roger Robinson and Nelson Wattie, eds. The Oxford Companion to New Zealand Literature. Auckland: Oxford University Press, 1998.

Rupp, Leila J. Mobilizing Women for War: German and American Propaganda, 19391945. Princeton: Princeton University Press, 1978.

Russ, Joanna. How to Suppress Women's Writing. London: The Women's Press, 1984.

Ryan, P.M. The Reed Dictionary of Modern Māori. Auckland: Reed Books, 1995.

Said, E. Orientalism. London: Routledge \& Kegan Paul, 1978.

Sargeson, Frank. Sargeson. Auckland: Penguin, 1981.

Sargeson, Frank. In Kevin Cunningham, ed. Conversation in a Train and Other Critical Writing. Auckland: Auckland University Press/OUP, 1983.

Sargeson, Frank. In Michael King. Wrestling with the Angel: a Life of Janet Frame. Auckland: Viking, 2000.

Sargison, Patricia A. Victoria's Furthest Daughters: A bibliography of published sources for the study of women in New Zealand 1830-1914. Wellington: Alexander Turnbull Library Endowment Trust with the New Zealand Founders Society, 1984. 
Saul, Jennifer. Feminism: Issues and Arguments. New York: Oxford University Press, 2003.

Schwass, Margot. 'Between two worlds: a study of migrant writers in New Zealand'. MA Thesis. Wellington: Victoria University, 1985.

Scruto. In numbers 1. 'Women, God Bless 'Em: Review of recent women's poetry'. Wellington: Literary Review, 1954.

Scott, T.H. In Kai Jensen. Whole Men: the Masculinist Tradition in New Zealand Literature. Auckland: Auckland University Press, 1996.

Sexton, Anne. In Carolyn G. Heilbrun. Writing a Woman's Life. New York: W.W. Norton, 1988.

Seymour, R. 'A Present Tendency in New Zealand Literature.' In New Zealand New Writing, No. 4' edited by lan A. Gordon, 31-34. Wellington: Progressive Publishing Society, 1945.

Shaw, Helen [guest editor, International ed; associate editor, Sandra Fowler; editor, Amal Ghose]. The Japonica sings: Ocarina's Anthology of New Zealand and World Poetry. Madras: Ocarina International, 1979.

Shaw, Helen, ed. Mystical Choice: 47 poems by New Zealand poets. Auckland: Mandala Editions, 1981.

Shepard, Deborah, ed. Between the Lives: Partners in Art. Auckland: Auckland University Press, 2005.

Shoebridge, Tim: Stories in Books and Stories of Life: Helen Shaw, New Zealand, c1937-1985. MA Thesis. Wellington: Victoria University, 2004.

Showalter, Elaine, ed. The New Feminist Criticism: Essays on Women, Literature, and Theory. New York: Pantheon Books, 1985.

Sinclair, Keith. In 'Memories of T.H. Scott'. Landfall 54. Christchurch: Caxton Press, June 1960. 
Smith, E.M. A History of New Zealand Fiction. Dunedin \& Wellington: A.H. \& A.W. Reed, 1939.

Smith, Linda Tuhiwai. 'Māori Women: Discourses, Projects and Mana Wahine.' In Women and Education in Aotearoa 2, edited by Sue Middleton and Alison Jones, 33-51. Wellington: Bridget Williams Books, 1992.

Smithyman, Kendrick. A Way of Saying: A Study of New Zealand Poetry. Auckland: Collins, 1965.

Stafford, Jane. 'Marsh, Edith Ngaio 1895 - 1982'. Dictionary of New Zealand Biography, updated 22 June 2007. URL: http://www.DNZB.govt.New Zealand

Stafford, Jane. 'B.E. Baughan, 1870-1958'. In Paul Millar, Jane Stafford \& Mark Williams, eds. Kotare 2008. Special Issue - Essays in New Zealand Literary Biography Series Three: 'The Early Poets.' www.New Zealandetc.org/tm/scholarly/tei-Whi073Kota

Stafford, Jane \& Mark Williams. Maoriland: New Zealand Literature 1872-1914. Wellington: Victoria University Press, 2006.

Stanley, Liz \& Sue Wise, eds. Breaking Out Again: Feminist Ontology and Epistemology. Oxford, UK: Routledge, 1993.

Stead, C.K. New Zealand Short Stories: Second Series. Auckland: Oxford University Press, 1966.

Stead, C.K. In the Glass Case: Essays on New Zealand Literature. Auckland: Auckland University Press with Oxford University Press, 1981.

Stead, C.K. Answering to the Language: Essays on Modern Writers. Auckland: Auckland University Press, 1989.

Steeds, Bernie. 'Mysterious double Life of Dame Ngaio Marsh.' Evening Post, April 15 1995.

Stein, Gertrude. Lectures in America. London: Virago Press, 1988. 
Stevens, Joan. Some Nineteenth Century Novels and their First Publication. Wellington: Government Printer, 1961.

Stevens, Joan. The New Zealand Novel 1860-1965. Wellington: Reed, 1966.

Sturm, J.C. 'The Māori Women's Welfare League'. Te Ao Hou No. 9, Spring, 1954, p8.

Sturm, J.C. Dedications. Wellington: Steele Roberts, 1996.

Sturm, J.C. Postscripts. Wellington: Steele Roberts, 2000.

Sturm, J.C. In Michael O'Leary, ed. Tiger Words: Paekakariki poets at Pukapuka. Paekakariki: Earl of Seacliff Art Workshop, 2002.

Sturm, J.C. House of the Talking Cat. Wellington: Steele Roberts, 2003.

Sturm, J.C. In Deborah Shepard, ed. Between the Lives: Partners in Art. Auckland: Auckland University Press, 2005.

Sturm, Terry, ed. The Oxford History of New Zealand Literature in English. Auckland: Oxford University Press, 1998.

Sturm, Terry. 'Popular Fiction'. In Terry Sturm, ed. The Oxford History of New Zealand Literature in English. Auckland: Oxford University Press, 1998.

Sturm, Terry. 'Romance Fiction'. In Roger Robinson and Nelson Wattie, eds. The Oxford Companion to New Zealand Literature. Auckland: Oxford University Press, 1998.

Sturm, Terry. 'Scanlan, Ellen Margaret 1882 - 1968'. Dictionary of New Zealand Biography, updated 22 June 2007. URL: http://www.dnzb.govt.nz/ Sutch, W.B. Women with a Cause. Wellington: New Zealand University Press, 1974.

Swarbrick, Nancy. 'Rees, Rosemary Frances 1875/1876? - 1963'. Dictionary of New Zealand Biography, updated 22 June 2007. URL: http://www.DNZB.govt.New Zealand.

Takurua, Anaru Kingi. 'Ngawai, Tuini Moetu Haangu 1910 - 1965’. Dictionary 
of New Zealand Biography, updated 22 June 2007. URL: http://www.DNZB.govt.New Zealand.

Thomson, John N, ed. Five New Zealand Plays. Auckland: Collins Publishers, 1962.

Thwaite, J.L. The importance of being Eve Langley. Sydney: Angus \& Robertson, 1989.

Tod, Frank. The History of Seacliff. [Seacliff: Private Publication, c1970.]

Todd, Janet, ed. Gender and Literary Voice. New York: Holmes \& Meier Publishers, 1980.

Tolerton, Jane. 60s Chicks hit the nineties. Auckland: Penguin Books, 1997.

Tong, Rosemary. Feminist Thought: a more comprehensive introduction [2 ${ }^{\text {nd }}$ Ed]. Colorado: Westview Press, 1998.

Torrey, E. Fuller. The Roots of Treason: Ezra Pound and the Secrets of St Elizabeth's. London: Sidgwick \& Jackson, 1984.

Trilling, Lionel. In Smithyman, Kendrick. A Way of Saying: A Study of New Zealand Poetry. Auckland: Collins, 1965.

Trussell, Denys. Fairburn. Auckland: AUP/OUP, 1984.

Tupuola, Anne-Marie, et al, eds. Ehara i a Koe Anake: You're Not Alone: A Collection of Young Women's Writing. Wellington: Y.W.C.A., 2000.

Tyler, Linda. In Deborah Shepard, ed. Between the Lives: Partners in Art. Auckland: Auckland University Press, 2005.

Waite, Noel. In Griffith, Penelope, Peter Hughes \& Alan Loney eds. A Book in the Hand. Auckland: Auckland University Press, 2000.

Wattie, Nelson. In Roger Robinson, and Nelson Wattie, eds. The Oxford Companion to New Zealand Literature. Auckland: Oxford University Press, 1998. 
Webby, Elizabeth and Lydia Wevers, eds. Goodbye to Romance: Stories by New Zealand and Australian Women Writers 1930-1988. Wellington: Allen \& Unwin in association with Port Nicholson Press, 1989.

Wedde, lan \& Harvey McQueen [eds]. Penguin Book of New Zealand Verse. Auckland: Penguin, 1985.

Weston, L.C. and J.A. Ruggiero. 'Male-Female Relationships in Best-Selling 'Modern Gothic' Novels.' Sex Roles vol.4 no.5 (1978).

Westra, Ans. In Terry Sturm, ed. The Oxford History of New Zealand Literature in English. Auckland, New Zealand: Oxford University Press, 1998.

Wevers, Lydia. In Terry Sturm, ed. The Oxford History of New Zealand Literature in English. Auckland: Oxford University Press, 1998.

Wevers, Lydia. 'Scott, Mary Edith 1888 - 1979'. Dictionary of New Zealand Biography, updated 22 June 2007. URL: http://www.dnzb.govt.nz/

Wevers, Lydia. 'False Scent'. (Arts \& Books) New Zealand Listener November 15-21 (2008).

Whiteford, Peter. 'Ursula Bethell, 1874-1945'. In Paul Millar, Jane Stafford \& Mark Williams, eds. Kotare 2008. Special Issue - Essays in New Zealand Literary Biography Series Three: 'The Early Poets.' www.New Zealandetc.org/tm/scholarly/tei-Whi073Kota

Whiteford, Peter, ed. Eileen Duggan: Selected Poems. Wellington: Victoria University Press, 1994.

Whiteford, Peter. 'Eileen Duggan, 1894-1972'. In Paul Millar, Jane Stafford \& Mark Williams, eds. Kotare 2008. Special Issue - Essays in New Zealand Literary Biography Series Three: 'The Early Poets.' www.New Zealandetc.org/tm/scholarly/tei-Whi073Kota

Williams, Mark. 'Introduction'. In Paul Millar, Jane Stafford \& Mark Williams, eds. Kotare 2008. Special Issue - Essays in New Zealand Literary Biography Series Three: 'The Early Poets.' www.New Zealandetc.org/tm/scholarly/tei-Whi073Kota 
Wilson, Guthrie. Brave Company. Auckland: Paul's Book Arcade, 1962.

Woolf, Virginia. The Common Reader. London: The Hogarth Press, 1957.

Woolf, Virginia. In Elaine Showalter, ed. The New Feminist Criticism: Essays on Women, Literature, and Theory. New York: Pantheon Books, 1985.

Woolf, Virginia. A Room of One's Own. Oxford, UK: Oxford University Press, 2000.

Wordsworth, Jane. Leading Ladies: Twenty-three Outstanding Women. Wellington: A.H. \& A.W. Reed, 1979.

Worthington, Kim. 'Jane Mander'. In Roger Robinson and Nelson Wattie, eds. The Oxford Companion to New Zealand Literature. Auckland: Oxford University Press, 1998.

Wright, Dr. F.W. Nielsen. The Unlikeliest Litterateur. Te Aro, Wellington: Original Books, 1995.

Wright, Dr. F.W. Nielsen. An Account of the Poet Esma North. Te Aro, Wellington: Cultural and Political Booklets, 1998.

Wright, Dr. F.W. Nielsen. How About Honouring the New Zealand Poet Ruth Gilbert on her $85^{\text {th }}$ Birthday: a Nomination. Te Aro, Wellington: Original Books, 2001.

Wright, Dr. F.W. Nielsen. On the Significance of Joan Stevens as Modern Poetry Expert in Aotearoa New Zealand in 1952. Te Aro, Wellington: Cultural and Political Booklets, 2006.

Wright, Dr. F.W. Nielsen. A Checklist of Anthologies and Critical Books etc. Published in 1945-1970 Regarding Aotearoa Poetry. Te Aro, Wellington: Cultural and Political Booklets, 2007.

Wright, Dr. F.W. Nielsen. A.R.D. Fairburn and the Women Poets of 1948 in Aotearoa: an Essay. Te Aro, Wellington: Cultural and Political Booklets, 2007. 
Wright, Dr. F.W. Nielsen. Noble Initiatives: Notes on Women's Writing in Aotearoa 19522002. Te Aro, Wellington: Cultural and Political Booklets, 2007.

Wright, Dr. F.W. Nielsen. Sketch Profile of Ruth Gilbert with Full Commentary: Quoting Various Authors. Te Aro, Wellington: Cultural and Political Booklets, 2007.

Wright, Dr. F.W. Nielsen. Notes on Marjory Lydia Nicholls Complete Poems. Te Aro, Wellington: Original Books, 2009.

NB: A word on the bibliography for 'Social and Literary Constraints on Women Writers in New Zealand 1945-1970'. Like the rest of the study I hope that this bibliography will serve as a catalyst for further study. There are many areas that this thesis touches on or brings attention to concerning the study of women's literature in New Zealand during the period it covers and beyond. The same applies to the material in the appendices, much of which might be followed in future studies beyond the scope of this thesis. Indeed, I will consider this work to be a success if it leads to further work in this field.

Michael O'Leary, Paekakariki, 2011. 


\section{Appendices for}

\section{Social and Literary Constraints \\ On Women Writers \\ In New Zealand 1945-1970}

\section{By}

\section{Michael John O'Leary}

These appendices are designed to clarify and give additional information for the material in this thesis. They are necessary to provide further understanding and involve documents too large to incorporate into the main text. In, for example, the work of Rowan Gibbs I have left the format he presents his bibliographical work in even though it differs in from the Chicago Style Guide I have used for my own bibliography. This also applies to other aspects of the individual appendices, although I have done considerable work on each of them to make each one relevant and informative. 


\section{Appendix 1}

\section{From ROSEMARY REES: A BIBLIOGRAPHY ${ }^{1}$}

\section{BOOKS}

April's Sowing. London: Herbert Jenkins, Limited, 1924 [i.e. 1923] (dated from ECB). Serialised in the Boston American 1929 (syndicated in other Hearst American newspapers). This entry for April's Sowing illustrates the detailed bibliographical work that Mr Gibbs has provided for most of the titles in the Rosemary Rees' bibliography. What emerges from this is her vast publishing history and her popularity.

First impression unseen - assumed to be identical to Colonial edition except for dust jacket

[all inside double frame] APRIL'S | SOWING | BY | ROSEMARY REES | HERBERT JENKINS, LIMITED | 3 YORK STREET, ST. JAMES'S | LONDON S.W.I [2 ornaments] MCMXXIV

[1-8] 9-312 [8]pp. ([A]8 B-U8: 160 leaves); pp.[313-320] publisher's adv.; printed at Athenaeum Printing Works, Redhill; pale greenish-grey cloth, spine \& front board lettered in dark green, $190 \mathrm{~mm}$; white pictorial dust jacket by Frank Marston (heads of man and apprehensive woman; price $7 / 6$ on spine panel).

Published Sept. 1923 at 7s6d.; advertised Observer 16 Sept. 1923 p.4.

Dedication: 'To Bertie'.

$\mathrm{BL}$

ECB; Bagnall R320: 'Romance set in Whangamata'.

'Why did Mary Brandon choose New Zealand to start life afresh? [ ... ] She wanted to get away from everything [ ... ] In Whangamata she meets Jim Carlyon, a drunkard and remittance man-a man with a past [ ... ]': 'What this Story is About' p.[2].

'Mary Brandon has a past and she goes to New Zealand to forget it; John Carlyon sees and loves her; but his enemy, drink, comes between them. Difficulties and trouble eventually bring them together' - publisher's advertisement Observer 16 Sept. 1923 p.4.; Times 21 Sept. 1923 p.15.

Rees wrote later of this book: 'April's Sowing, my first book, was also my very first attempt at a novel ... within five weeks I had it finished ... My book [was] accepted by the first publisher to whom it had been submitted...': How I Wrote My First Novel (typescript in WTu).

Colonial Edition:

London: Herbert Jenkins Limited, 1924 [i.e. 1923?].

As U.K. trade edition apart from dust jacket which has green label stating 'Herbert Jenkins' Colonial Library' on sticker affixed to spine panel covering original printed price.

WTu; RG

Popular edition:

London: Herbert Jenkins [1925] (dated from ECB).

[all inside double frame] APRIL'S | SOWING | BY | ROSEMARY REES | HERBERT JENKINS, LIMITED | YORK STREET LONDON S.W.I

[1-8] 9-312 [8]pp. ([A]16B-K16: 160 leaves), 'Popular Edition' on verso-title; pp.[313-320] publisher's adv.; pp.[7]-312 apparently same setting of type as first edition; printed at Athenaeum Printing Works, Redhill; pale greenish-grey cloth, spine \& front board lettered in black, $180 \mathrm{~mm}$; dust jacket unseen.

Published January 1925 at 2s.

$R G$

ECB

Second printing

Not traced

Third printing:

[4] [1-4] 9-312 [4]pp.; same collation as 'Popular Edition' above but 2 integral blank leaves at beginning and 2 at end; 'Third printing, completing 12,286 copies' on verso-title; 
ownership inscription in copy seen dated 'July 1931'; pp.[7]-312 apparently same setting of text as previous editions; printed by Purnell and Sons; dust jacket unseen.

RG

Cheap edition:

London: Wright \& Brown Ltd [1935] (dated from ECB).

[all inside frame] April's Sowing | [rule] | By | Rosemary Rees | [publisher's device] | [rule] | Wright \& Brown | 4 Farringdon Avenue | London, E.C.4

[4] [1-8] 9-312 [4]pp. ([A]8B-U8: 160 leaves; front \& rear pastedowns and free endpapers are integral); pp.[7]-312 apparently same setting of type as first edition; list of works 'By the Same author' on p.[2] has 4 titles, the last Hetty; printed by Purnell and Sons; red cloth, spine lettered in black, $190 \mathrm{~mm}$; dust jacket unseen.

Published Feb.1935 at 2s6d.

$W U ; R G$

ECB; Bagnall R321

Variant printing:

As preceding but list of works 'By the Same Author' has 8 titles, the last Sane Jane.

RG

U.S. edition:

New York: Arcadia House, 1936.

318pp. $19.5 \mathrm{~cm}$.

LC (LC 37-771921)

Bagnall R322

Heather of the South. London: Herbert Jenkins, 1924.

(Bagnall, R334: 'Romance on a New Zealand dairy farm'. Summary: Heather and her mother return to New Zealand from Paris to run the family farm, after the disappearance of Heather's brother Tom. Heather blames Stephen Creed for their misfortunes, until Tom returns to clear the misunderstanding).

Lake of Enchantment. London: Herbert Jenkins Limited, 1925.

(Bagnall R345: 'Set in part on the de Lautour Otago run'. 'At thirty-two Elizabeth Arlin returns to her native New Zealand to escape from Mark Wynyard and the hurly-burly of an artificial life. Elizabeth is an actress; her first novel has just been accepted by a publisher, but Elizabeth has had a nervous breakdown. A charming romance of New Zealand, of the life of simple, kindly folk, of sheep-shearing, of lovely country and Maori legend').

'Life's What You Make It!' London: Herbert Jenkins Ltd, 1927.

(Bagnall R347. 'Candida and Lane Fullarton, a young English couple visiting New Zealand, are the most popular members of the fishing camp at Taranui [ ... ] Romance and mystery blend in this powerful and enthralling love story...The scene of this romance is laid in a New Zealand fishing camp such as the Duke and Duchess of York recently visited. 'TAKE YOUR HAPPINESS WHERE YOU FIND IT! LIFE'S WHAT YOU MAKE IT!'. Romance and mystery are blended in this powerful and enthralling love story').

Wild, Wild Heart. London: Chapman \& Hall, 1928. (Bagnall R371).

Dear Acquaintance. London: Chapman \& Hall Ltd, 1929.

(Bagnall R326 'Here is a romantic love-story, merging into a tale of mystery. The heroine is a charming Australian girl, who finds her way upon the London stage. The scene shifts from behind the scenes to the Basque country surrounding Biarritz, and the story comes to a crisis in the Central Criminal Court at the Old Bailey').

Sane Jane. London: Chapman and Hall Ltd, 1931.

(Bagnall R362)

Concealed Turning. London: Wright \& Brown, 1932.

(Bagnall R325) 
Local Colour. London: Chapman \& Hall Ltd, 1933.

(Bagnall R349, Published in U.S.A. as Hetty Looks for Local Color. New York: Arcadia House, 1935).

Home's Where the Heart is. London: Chapman and Hall Ltd, 1935.

(Bagnall R339: 'An English girl on a South Island sheep station. Miss RR is always at home in New Zealand, the enchanted country of her heart; but Beth Harland, the heroine of her latest story, was an exile from England, and when she came to Waipa she felt herself a homesick pilgrim and a stranger [ ... ] The life of a New Zealand sheep farm is full of rough character; the passions run high there; the Ten Commandments are at a discount; it is all a rude awakening for a gently-nurtured English girl).

Miss Tiverton's Shipwreck. London: Chapman and Hall Ltd., 1936.

(Bagnall R354)

Turn the Hour. London: Chapman and Hall Ltd, 1937. (Bagnall R369 'Domestic romance set in small New Zealand town. Miss RR's new novel finds her back in the New Zealand she knows so well, but it is a New Zealand of many changes, for even in these distant outposts of Empire the modern spirit makes itself felt ... an attractive and invigorating story').

Sing a Song of Sydney. London: Chapman and Hall Ltd, 1938.

(Bagnall states: 'Originally announced with title: Guest House'. This statement derives from Chapman \& Hall's Spring 1938 catalogue. 'This is a novel of present day life in the lovely city of Sydney and the country districts of New South Wales ... a swiftly moving story of intrigue, business interests, stage life, and romance').

You'll Never Fail Me. London: Chapman and Hall Ltd, 1939.

(Bagnall R375. Set Sussex, London, and New Zealand: 'Tom Eldridge, a public-school boy of seventeen, orphaned and unhappy in his Sussex home where his step-mother rules supreme, seeks his fortune overseas. Returning to England thirteen years later he has an unexpected meeting with his former playmate Kathie: there is an element of mystery as well as a strong love interest').

I Can Take Care of Myself. London: Chapman and Hall Ltd, 1940.

(Bagnall R344: published in U.S.A. as Little Miss Independent. New York: Arcadia House, 1940.

Sackcloth for Susan. London: Chapman \& Hall, 1941.

(Bagnall R359: 'This is a freshly-told story of New Zealand country life ... Susan Garth, the motherless daughter of wealthy sheep-farmer, independent and self-willed... a bright and pleasant romance').

The Mended Citadel. London: Chapman and Hall Ltd, 1943.

(Bagnall R351: published in U.S.A. as Again We Dream. New York: Arcadia House, 1943.

Penelope Waits. London : Chapman \& Hall, 1946.

(Bagnall R357: 'A young Englishman seeks his fortune on a North Island farm').

Displaced Person. London: Chapman and Hall Ltd, 1948.

She Who Loves. London: Chapman \& Hall, 1952.

The Five Miss Willoughbys. London: Chapman \& Hall, 1955.

(Bagnall, R333: 'This is a story of social and domestic life in Sydney nearly a century ago ... a romantic rather than an historical novel ...').

Better to Trust. London: Chapman \& Hall, 1956.

(Bagnall R323: 'Romance set in England and New Zealand sheep station'). 
Love in a Lonely Land. London [etc.]: George G. Harrap \& Co. Ltd., 1958. (Bagnall R350: 'Set in Gisborne district in last century').

The Proud Diana. London: Wright \& Brown; [Christchurch] New Zealand: Whitcombe \& Tombs [1962]. ('Diana Roberts arrived in New Zealand from England to stay with her grandfather, who owned a sheep farm').

\section{FICTION}

\section{IN PERIODICALS}

In 'How I wrote my first novel' (typescript WTu qMS-1679) Rees states: 'During my early years on the stage, I had written a few short stories and a few one-act plays [ ... ]'.

An article on her in the Era [London] in 1908 (March?), quoted in the Evening Post 6 May 1908 p.11, states: 'Miss Rees, it is noted, has had stories accepted by many popular periodicals'.

Only three of these early stories have so far been traced:

- 'The Girl from New Zealand', mentioned in New Zealand Free Lance 1 August 1903 p.3 as published 'quite recently' in The King

o 'Molly' reprinted in Otago Witness 31 May 1905 p.82 ('By Rosemary Rees, in M.A.P.') - M.A.P., was Mainly about People, 'A popular penny weekly of pleasant gossip, personal portraits, and social news' published in London.

- 'Audrey, of Waikare' reprinted in Otago Witness 29 November 1905 p.94 ('M.A.P.')

Heather of the South and Lake of Enchantment were serialised in the Auckland Weekly News 'some years ago' - note in Aussie 15 June 1928.

April's Sowing was serialised in several of the Hearst group of papers in U.S.A. (Rees, 'Biographical notes' [1930], WTu qMS-1678)

Three of her novels were serialised in the London Evening Standard (Dominion 27 July 1955). These are noted under the entries for the books

At least one story was serialised in the Sydney Morning Herald (A Century of Journalism p.606); untraced.

She had at least twelve novels serialised in the Australian Woman's Mirror (Beltane Book Bulletin Oct-Nov.1952); those which have been traced are noted under the entries for the books. Some appeared under a different title from that of the novel, for example She Who Loves was serialised as 'Her Troubled Haven'.

\section{UNPUBLISHED FICTION}

In a letter to J.M. Goodwin dated 24 April 1959 (WTu MS-Papers-2423-2) Rees states that Harrap have accepted Love in a Lost Land but have declined her next novel 'Search for Sylvia' ('... I think the N.Z. restrictions on book imports have something to do with it, but all the same I don't think they liked the book - the first of my 24 to be turned down').

Obit. in Evening Post 19 August 1963 states that she '... recently wrote two more novels, not yet published'.

\section{NON-FICTION}

New Zealand Holiday. London: Chapman \& Hall, Ltd., 1933. 
'On a return trip to New Zealand in the summer of 1932-33 she researched a travel book for her English publisher. Political connections assisted: she was given advice by Gordon Coates, Adam Hamilton and Apirana Ngata. The resulting book, New Zealand holiday (1933), was enthusiastically reviewed in England and New Zealand. Breezy in tone, it gave an expatriate's affectionate, somewhat nostalgic impressions. Signs of economic depression were lightly dismissed, and the narrative was interspersed with facile views on race relations and colonisation.' - DNZB. Replying to a letter from Pat Lawlor in 1949 concerning a possible reprint or new edition of the book Rees stated: 'It is never likely to have any sensational sale but there should still be a steady demand for it as it still remains the only book giving information and descriptions of New Zealand written in a light and readable manner. When I was in New Zealand last year I took the opportunity to write a long 'foreword' bringing the book up to date...'; she felt no English publisher would be interested at present, unless the New Zealand government would agree to take 500 copies, and wondered if a New Zealand publisher might take it on. (WTu MS-Papers-77067-4/4).

\section{PLAYS}

In 1936 Rees described herself as 'Writer of many one act plays all produced in London' (letter to Johannes Andersen, 22 March 1936: WTu MS-Papers-0148-029M) and in 'How I wrote my first novel' (typescript WTu qMS-1679) she says: 'During my early years on the stage, I had written a few short stories and a few one-act plays, in one of which, produced at the Vaudeville Theatre and later at the Coliseum, I acted myself'.

Her only published play was the one-act

HER DEAREST FRIEND.

New York \& London: Samuel French, 1910 (Series: French's Acting Edition 2366).

$24 \mathrm{pp}$., diagr., $19 \mathrm{~cm}$.

(This includes cast list for production at the Coronet Theatre (by Percy Hutchison), 4 February 1907

BL; LC; NYPL

\footnotetext{
${ }^{1}$ This is a selection from Rosemary Rees' bibliography by Rowan Gibbs. As well as the title I have noted and added a note on each book which has New Zealand, Pacific Island or Australian themes, plus the Bagnall reference and description where applicable. There is a full version of Mr. Gibbs' work deposited in the Alexander Turnbull Library, Wellington, if more detailed research is required.
} 


\section{Appendix 2:}

\section{From NGAIO MARSH: SELECT BIBLIOGRAPHY ${ }^{1}$ NOVELS}

A Man Lay Dead. London: 1934, New York, 1942.

Enter A Murder. (London: 1935: New York, 1942)

The Nursing Home Murder, with Henry Jellett. (London, 1935: New York, 1941)

Death in Ecstasy. (London, 1936: New York, 1941)

Vintage Murder. (London, 1937: New York, 1940)

Artists in Crime. (London and New York, 1938)

Death in a White Tie. (London and New York, 1938)

Overture to Death. (London and New York, 1939)

Death at the Bar. (London and Boston, 1940)

Death of a Peer. (Boston, 1940: published as Surfeit of Lampreys, London, 1941)

Death and the Dancing Footman. (Boston, 1941: London, 1942)

Colour Scheme. (London and Boston, 1943)

Died in the Wool. (Auckland, 1944: London and Boston, 1945)

Final Curtain. (London and Boston, 1947)

A Wreath for Rivera. (Boston, 1949: published as Swing, Brother, Swing, London, 1949)

Night at the Vulcan. (Boston, 1949: published as Open Night, London, 1951)

Spinsters in Jeopardy. (Boston, 1953: London, 1954: published as The Bride of Death, New York, 1955)

Scales of Justice. (London and Boston, 1955)

Death of a Fool. (Boston, 1956: published as Off with His Head, London, 1957)

Singing in the Shrouds. (Boston, 1958: London, 1959)

False Scent. (Boston and London, 1960)

Hand in Glove. (Boston and London, 1962)

Dead Water. (Boston, 1963; London, 1964) 
Killer Dolphin. (Boston, 1966: published as Death at the Dolphin, London, 1967)

Clutch of Constables. (London, 1968: Boston 1969)

When in Rome. (London, 1968; Boston 1969)

Tied Up in Tinsel. (London and Boston, 1972)

Black as He's Painted. (London and Boston, 1974)

Last Ditch. (Boston and London, 1977)

Grave Mistake. (Boston and London, 1978)

Photo Finish. (London and Boston, 1980)

Light Thickens. (London and Boston, 1982)

\section{SHORT FICTION}

The Collected Short Fiction of Ngaio Marsh (ed.) Douglas G. Greene, New York, 1989 (This volume contains seven known short stories by Ngaio Marsh, plus other short pieces.)

'The Figure Quoted' (1927); rpt. in (ed.) O.N. Gillespie, New Zealand Short Stories (London and Toronto, 1930), 209-218;

'Moonshine'; in (ed.) Warwick Lawrence, Yours and Mine: Stories by Young New Zealanders (New Plymouth, NEW ZEALAND, 1936), 21-29;

'Murder at Christmas',(The Grand Magazine. December 1934); rpt. as 'Death on the Air', Ellery Oueen's Mystery Magazine January 1948 and in Ellery Oueen's 1969 Anthology. Vol.16 and Sean Manley and Sogo Lewis, Grand Dames of Detection (New York, 1973), 141-176;

'I Can Find My Way Out', Ellery Queen's Mystery Magazine. August 1946; rpt. in (ed.) Roy Vickers, Some Like Them Dead (London, 1960), 110-136 and Queen's Awards 1946 (Boston, 1946);

'Chapter and Verse: The Little Coppestone Mystery', Ellery Queen's Mystery Magazine. Vol. 61 (March 1973), 7-25; rpt. in Ellery Queen's Murdercade (New York, 1975; London, 1976);

'A Fool About Money', Ellery Queen's Mystery Magazine. Vol.62 (December 1974), 114118; rpt. in Ellery Queen's Crime Wave (New York, 1976).

'Morepork'; in (ed.) Julian Symons, Verdict of 13: A Detection Club Anthology (New York, 1978; London, 1979). 


\section{NON FICTION BOOKS AND MONOGRAPHS}

New Zealand [with R.M. Burdon] (London, 1942);

A Play Toward: A Note on Play Production (Christchurch, N.Z. 1946).

Play Production [with drawings by S.M. Williams] (Wellington, N.Z. 1948 revised 1960);

Perspectives: The New Zealander and the visual arts (Auckland, N.Z. 1960);

New Zealand: A Nation's Today Book (New York and London, 1964);

Black Beech and Honeydew (Boston, 1965; London, 1966; revised ed. Auckland, 1981; London, 1982).

\section{ARTICLES AND ESSAYS}

'The Background', The Press (Christchurch, N.Z.) 22 December 1934;

'German Anecdote', pp. 24-27; in Lady Newall's New Zealand Gift Book (Wellington, N.Z. 1943);

'Dialogue by Way of Introduction' (with Allen Curnow), First Year Book of the Arts in New Zealand (Wellington, N.Z. 1945), 1-8;

'Theatre: A note on the status quo', Landfall 1 (March 1947) 37-43;

'Shakespeare in New Zealand', Education. 1 (1948), 226-230;

'National Theatre', Landfall 3 (March 1949), 66-69;

'The Development of the Arts in New Zealand', Journal of the Royal Society of Arts. Vol. XCIX, No. 4840 (9 February 1951), 246-259;

'A Note on a Production of Twelfth Night', Shakespeare Survey. 8 (1955), 69-73;

'New Zealand, Welfare Paradise', ㅂoliday Magazine 28.5 (November 1960), 102-108;

'The Hand in the Sand'; in (ed.) John Creasey, The Mystery Bedside Book (London, 1960), 191-194;

'When You Take Up Writing You Are On Your Own', New Zealand Herald (Weekend Magazine, Section I), 26 May 1962.

'Shakespeariana's Lunatic Fringe', The Press. 24 April 1964;

'Stratford-on-Avon', The Atlantic Monthly (February 1967), 116-118;

'Achievement in Fine Arts', The Times. 6 February 1963 (New Zealand Supplement), p. 6;

'The Quick Forge', Landfall 18 (1964), 32-40; 
'Early Reading: Dame Ngaio Marsh on A Noah's Ark Geography', Education. Vol. 26:7 (1977), 25;

'Birth of a Sleuth'; in (ed.) A.S. Burack, Writing Suspense and Mystery Fiction (Boston, 1977), 123-128;

'Roderick Alleyn'; in (ed.) Otto PeNew Zealandler, The Great Detectives (Boston, 1978), 3-8;

'Entertainments', Pacific Moana Quarterly. Vol. 3:1 (January 1978), 27-31;

'Portrait of Troy'; in (ed.) Dilys Winn, Murderess Ink (New York, 1979), 142-43;

'Women on Women', Landfall 130 (June 1979), 101;

'Remembering John Schroder 1885-1980', Landfall 136 (December 1980), 406-407.

\section{BROADCASTS}

Recordings of radio and television broadcasts by Ngaio Marsh are held in the archives of BBC London, Radio New Zealand and New Zealand Television.

\section{PLAYS}

\section{Published}

The Christmas Tree (London, (1962) (Juvenile)

\section{Unpublished}

‘Little Housebound'; produced 1922, New Zealand.

‘Exit Sir Derek', (with Henry Jellett); produced 1935, New Zealand.

'Surfeit of Lampreys', Marsh (with Owen B. Howell); produced 1950, UK.

'The Wyvern and Unicorn', produced 1955, New Zealand. This play was the basis for the libretto written by Marsh for the opera 'A Unicorn for Christmas', produced 1962, New Zealand.

'False Scent' revised (with Eileen Mackay); produced 1961, UK.

'Sweet Mr. Shakespeare' (with Jonathan Elsom), produced 1976, New Zealand; Norwegian Television 1985 as 'Gentle Master Shakespeare'. 


\section{TELEVISION SCRIPT}

'Evil Liver'; broadcast 1975, Granada, UK. (Published in The Collected Short Fiction of Ngaio Marsh, (ed.) Douglas G. Greene, New York, 1989.)

${ }^{1}$ (Source: Website) Rowan Gibbs and Richard Williams, Ngaio Marsh: A Bibliography (Scunthorpe, UK, 1990) www.ngaio-marsh.org.New Zealand/biblio 


\section{Appendix 3:}

\section{From DOROTHY QUENTIN: A SHORTER BIBLIOGRAPHY ${ }^{1}$}

FICTION

as MADELEINE H. MURAT

Sidestreets. London, NY: Putnam, 1932.

New Soul. London, NY: Putnam, 1933.

as MARTIN TREE

Shutters. London: Peter Davies, 1936.

Genesis. London: PeterDavies,1937.

as LINDA BEVERLY

Brave Enterprise. New York: Arcadia House, 1943.

Island Refuge. New York: Arcadia House, 1943.

Love Go With You. New York: Arcadia House, 1944.

So Shadows Pass. New York: Arcadia House, 1943.

as DAVID KING

The Mountains Are Still Green. London \& Melbourne: Ward, Lock, 1950. (Set in New Zealand - 'a costume romance which begins in the year 1836 and ends in $1948 \ldots$...' Bagnall B392a)

as DOROTHY QUENTIN

Brave Enterprise. London \& Melbourne: Ward, Lock, 1939. (Set in England (Sussex, London) and 'Parahoi', a Polynesian island)

If I Should Love You. London \& Melbourne: Ward, Lock, 1939.

Voyage to Paradise. London \& Melbourne: Ward, Lock, 1940.

(A romance, set on the Pacific island of 'Raitana'.)

Rhapsody in Spring. London \& Melbourne: Ward, Lock, 1940.

Errand of Mercy. London \& Melbourne: Ward, Lock, 1941.

So Shadows Pass. London \& Melbourne: Ward, Lock, 1942.

Bright Tomorrow. New York: Arcadia House, 1942.

There's No Escape. London \& Melbourne: Ward, Lock, 1943.

Nurse Sally Dean. New York: Arcadia House, 1943.

Sob-Sister. London \& Melbourne: Ward, Lock, 1943. (Set on 'Marama' in the South Pacific)

Angel in the Rain. New York: Arcadia House, 1944. 
Challenge to Anne. New York: Arcadia House, 1944.

Sell Me Your Life. London \& Melbourne: Ward, Lock, 1944.

Love Go With You. London \& Melbourne: Ward, Lock, 1944. (Romance on a ship taking evacuee children to New Zealand)

Sparkling Waters. London \& Melbourne: Ward, Lock, 1945. (Romance set on the Waitemata Harbour. Bagnall B394)

Love Sails at Dawn. New York: Arcadia House, 1945. (Shipboard romance, Liverpool to Sydney)

Morning Star. Published (complete) as supplement to Star Weekly, Toronto, 26 August 1944. (Hospital romance set New Zealand)

Bright Horizon. New York: Arcadia House, 1946.

Tomorrow is Another Day. New York: Arcadia House, 1946.

Ship’s Nurse. New York: Arcadia House, 1947.

Maiden Voyage. London \& Melbourne: Ward, Lock, 1948.

The Singing Hills. London \& Melbourne: Ward, Lock, 1949. (Romance set England and New Zealand)

The Golden Hibiscus. London \& Melbourne: Ward, Lock, 1949. (Filming in London and on the Pacific island of 'Kiritana')

Little Mansions. London \& Melbourne: Ward, Lock, 1950.

Reach Me a Star... London \& Melbourne: Ward, Lock, 1950. (Romance for an actress in England and New Zealand)

Flamingo Island. London \& Melbourne: Ward, Lock, 1951.

The Winds of Love. London \& Melbourne: Ward, Lock, 1951.

The Honest Heart. London \& Melbourne: Ward, Lock, 1952.

Dear Anna. London \& Melbourne: Ward, Lock, 1952. (Set on board a ship travelling from England to New Zealand)

Love in Four Flats. London \& Melbourne: Ward, Lock, 1953.

The Blue Gum Tree. London \& Melbourne: Ward, Lock, 1953. (Set in New Zealand - 'the Thames hills'. Bagnall B391)

Harbour My Heart. London \& Melbourne: Ward, Lock, 1954.

The Inn by the Lake. London \& Melbourne: Ward, Lock, 1954.

Inheritance of Love. London \& Melbourne: Ward, Lock, 1955. (Shipboard romance en route to New Zealand)

The Generous Heart. London \& Melbourne: Ward, Lock, 1955. (Set on 'the Pacific island of Te Marama' with stop-over in Auckland. Bagnall B392)

Reflection of a Star. London \& Melbourne: Ward, Lock, 1956. 
Prelude to Love. London \& Melbourne: Ward, Lock, 1956.

Forsaken Paradise. London: Ward, Lock, 1957. (Set 'Samoya' in the South Pacific (and briefly Australia). Bagnall sB391a)

Dream of Love. London, Melbourne \& Cape Town: Ward, Lock, 1957.

Love Me by Moonlight. London, Melbourne \& Cape Town: Ward, Lock, 1958. (Shipboard romance for a nurse en route to New Zealand)

The House by the Sea. London: Ward, Lock, 1958.

The Unchanging Love. London, Melbourne \& Cape Town: Ward, Lock, 1959. (Romance set in a New Zealand country hospital)

Whispering Island. London: Ward, Lock, 1959.

Lugano Love Story. London, Melbourne \& Johannesburg: Ward Loc, 1960.

Rainbow Valley. London, Melbourne \& Johannesburg: Ward Lock, 1960. (Hospital romance set in a small town south of Auckland. Bagnall B393)

The Prisoner in the Square. London, Melbourne, Johannesburg: Ward Lock, 1961 (March/May?). 191, [1]pp., 11/6. (Nursing romance set London and Cornwall)

(This entry for The Prisoner in the Square shows the detailed bibliographical work that $\mathrm{Mr}$ Gibbs has provided for most of the individual titles in 'DOROTHY QUENTIN A LA RECHERCHE DE LA MADELEINE PERDUE: A BIBLIOGRAPHICAL ROMANCE' see his book of that name for details of each of the books in this 'Select bibliography' which I have distilled from Mr Gibbs' work. What emerges from this is the vast publishing history of the writings of Dorothy Quentin, the number of languages she was translated into, and her popularity worldwide.)

- Cheap edition 1962 (August), 6/6.

— US edition. NY: Pyramid Books, 1968 (May) ('A Pyramid Gothic X-1803'). 191pp.; 51101803-060; pb; 60ф- Reprinted: Pyramid N2830; 'Second printing, October 1972'; 0-51502830-4; pb; 95c

- Dutch translation: DE KLEINE GEVANGENE. Haarlem: De Spaarnestad [no date]. 222pp.

- German translation: KINDERSCHWESTER MANDY [Translated by Thilde von der Ohe]. Düsseldorf: Dörner, 1962. 299pp.; boards; price DM 11,80.

- New edition. Hamburg: Dt. Literatur-Verl. Melchert, 1965 (Bücher der Gartenlaube Bd. 21). 158,[1]pp.; pb; price DM 2,40.

- New edition: Hamburg: Xenos Verlagsgesellschaft, 1979 (Super-Roman Nr.109R80). 158,[1]pp.; pb.

same?? 1985

- German Braille edition: 2 Bde., alte Kurzschrift/Zwischenpunktdruck, BNA 11041 [http://www.dzb.de]

- Norwegian translation: MER ENN SKJØNNHET. Oslo: Fredhøi, 1962 (Damenes roman 102). 157pp.

- Reprint 1972. 142pp.

- Swedish translation: DRÖMMEN OM EN MOR. Stockholm: Wahlström, 1970. 153pp.

- Reprint. '2-5. ed.', 1975. 157pp.

The Eagle and the Dove. London, Melbourne, Johannesburg: Ward, Lock, 1961. 
Imprudent Lover. London: Ward, Lock, 1962.

Dangerous Affair. London, Melbourne, Cape Town: Ward Lock, 1962.

The Doctor's Destiny. London, Melbourne, Cape Town: Ward, Lock, 1963. (Set on Papaaluva, 'a remote Pacific island')

The Dark Castle. London: Ward, Lock, 1963.

Perilous Voyage. London \& Melbourne: Ward, Lock, 1964. (Shipboard romance, England to New Zealand)

The Cottage in the Woods. London \& Melbourne: Ward, Lock, 1964.

The Healing Tide. London \& Melbourne: Ward, Lock, 1965. (A jilted nurse finds romance on a ship to New Zealand)

The One I Want. London \& Melbourne: Ward Lock, 1965

House of Illusion. London: Ward, Lock, 1966.

Duel Across the Water. London \& Melbourne: Ward Lock, 1966.

Lantana. London: Ward, Lock, 1967. (Set on an island in the South Pacific)

What News of Kitty? London \& Melbourne: Ward, Lock, 1967.

Wedding at Blue River. London \& Melbourne: Ward, Lock, 1968. (Romance set in Devon and in the Australian Outback)

The Little Hospital. London \& Sydney: Ward Lock, 1968.

Goldenhaze. London: Mills \& Boon, 1969. (Set New Zealand - 'It was only after her mother died that Mandy learned that she was in reality the granddaughter of a rich old farmer in New Zealand...')

The Beach House. London: Mills \& Boon, 1969.

Last Voyage Home. London: Mills \& Boon Limited, 1970. Romance for a nurse on board a ship from New Zealand to England.

The Wild One. London: Mills \& Boon Ltd, 1970. (Romance set on Vahine 'her paradise island home in the South Seas' with many New Zealand references)

Mistress of Penharrow. London: Mills \& Boon Limited, 1971. (Romance set Cornwall, with New Zealand references)

My Heart the Pledge. London: Mills \& Boon Limited, 1972. (Hospital romance set on 'the Pacific island of Mindana')

The Winds of Change. London: Mills \& Boon Ltd, 1973. (A New Zealander in Cornwall finds romance and his roots)

Conflict in the Sun. London: Mills \& Boon, 1976. (Set in the Pacific, 'the island of Manava') 
${ }^{1}$ This is a shorter version of Dorothy Quentin: 'A LA RECHERCHE DE LA MADELEINE PERDUE: A BIBLIOGRAPHICAL ROMANCE' by Rowan Gibbs. As well as the title I have added to the information of each book which has New Zealand, Pacific Island or Australian themes, plus the Bagnall reference where applicable. There is a full version of Mr. Gibbs work deposited in the Alexander Turnbull Library, Wellington, if more detailed research is required. Born Madeleine Murat, Dorothy Quentin also wrote under pseudonyms of Martin Tree, Linda Beverly and David King. 


\section{Appendix 4:}

\section{From DOROTHY EDEN: A SHORTER BIBLIOGRAPHY}

BOOKS IN CHRONOLOGICAL ORDER

(with dates of first editions in U.K. and U.S.A.)

Singing Shadows. London: Stanley Paul, 1940.

The Laughing Ghost. London: Macdonald \& Co., 1943; New York: Ace Books, $1967 ?$

We Are For The Dark. London: Macdonald \& Co., 1944.

Summer Sunday. London: Macdonald \& Co., 1946.

Walk Into My Parlour. London: Macdonald \& Co., 1947.

The Schoolmaster's Daughters. London: Macdonald \& Co., 1948; published in U.S.A. as The Daughters of Ardmore Hall. New York: Ace Books, 1968?

Crow Hollow. London: Macdonald \& Co., 1950; New York: Ace Books, 1967.

The Voice of the Dolls. London: Macdonald \& Co., 1950; New York: Ace Books, 1971?

Cat's Prey. London: Macdonald \& Co., 1952, Ace Books, 1967 ? (reprinted under title Let us Prey. Severn House, 1995).

Lamb to the Slaughter. London: Macdonald \& Co., 1953; published in U.S.A. as The Brooding Lake. New York: Ace Books, 1966.

Bride by Candlelight. London: Macdonald \& Co., 1954; New York: Ace Books, 1972?

Darling Clementine. London: Macdonald \& Co., 1955; published in U.S.A. as Night of the Letter. New York: Ace Books, 1967.

Death is a Red Rose. London: Macdonald \& Co., 1956, New York: Ace Books, 1970.

The Pretty Ones. London: Macdonald \& Co., 1957; New York: Ace Books, 1966?

Listen to Danger. London: Macdonald \& Co., 1958; New York: Ace Books, 1966.

The Deadly Travellers. London: Macdonald \& Co., 1959; New York: Ace Books, 1966.

The Sleeping Bride. London: Macdonald \& Co., 1959; New York: Ace Books, 1966?

Sleep in the Woods. London: Hodder \& Stoughton, 1960; New York: Coward, 1961.

Samantha. London: Hodder \& Stoughton, 1961; published in U.S.A. as Lady of Mallow. New York: Coward, 1962.

Face of an Angel. (under pseudonym Mary Paradise). London: Robert Hale, 1961; New York: Ace Books, 1966.

Afternoon for Lizards. London: Hodder \& Stoughton, 1961; published in U.S.A. as Bridge of Fear. New York: Severn House, 1961. 
[This entry for Afternoon for Lizards illustrates the detailed bibliographical work that Mr Gibbs has provided for most of the titles in the Dorothy Eden bibliography which I have distilled from Mr Gibbs' work. What emerges from this is the vast publishing history, as with Dorothy Quentin, the number of editions and languages she was translated into, and her popularity worldwide.]

Mystery novel set in Australia

First edition - U.K. hardback, 14 Sept. 1961:

AFTERNOON FOR | LIZARDS | by | DOROTHY EDEN | London | HODDER \& STOUGHTON

On verso-title: 'MADE AND PRINTED IN GREAT BRITAIN FOR | HODDER AND STOUGHTON LIMITED, LONDON | BY C. TINLING AND CO. LIMITED, LIVERPOOL, | LONDON AND PRESCOT | Copyright ( 1961 by Dorothy Eden | First Printed 1961 [ ... ]' [1-6]7-192pp., green boards, spine lettered in gold, 190mm; yellow dust jacket (woman lying on ground, trees; 'Wrapper design by Eileen Walton'; quotation from Dorothy Eden Books and Bookmen interview on lower flap); price '12s6d net' at foot of front flap.

Dedication: 'For WIN and BERNIE | whose garden and kookaburras | I borrowed'. [RG]

New U.S. (and U.K.?) edition as BRIDGE OF FEAR.

***Severn House [Feb.] 1993. (1962. 190pp. ISBN 072784394X. [RLIN and NLA give sole place of publication as New York; not in LC, COPAC]

U.K. large print edition, Oct. 1 1977:

${ }^{* * \star A F T E R N O O N ~ F O R ~ L I Z A R D S . ~ L e i c e s t e r: ~ U l v e r s c r o f t, ~ 1977 . ~ 318 p p . ~ £ 2.95 ~ I S B N ~}$ 0708900569.

New U.K. / U.S. large print edition, hbk 30 Sept. 2001; pbk 31 March 2002:

***BRIDGE OF FEAR - AFTERNOON FOR LIZARDS. Bath, U.K.: Chivers Press;

Waterville, Me.: G.K. Hall, 2001. (Nightingale Series). 259pp.; 220mm.

ISBN 0783895003 (U.S. pbk); 0754045684 (U.K. hbk, £14.99); 0754045692 (U.K. pbk, $£ 8.50)$.

U.K. paperback, April 1968:

[all set leff] dorothy eden | afternoon for lizards | [imprint: hodder02]

On verso-title: ' $[$... ] hodder paperback edition 1968 | made and printed in great britain for | hodder paperbacks limited, london | by richard clay (the chaucer press) Itd, | bungay, suffolk | sbn 34002926 9'; 2926 on spine; [1-6]7-191[192]pp., orange pictorial wrappers (woman sitting on felled tree, mansion), $177 \mathrm{~mm}$; price $3 \mathrm{~s} 6 \mathrm{~d}$. [RG]

Reprint, 1969:

***'Second impression 1969' [listed in 3rd impr.]

Reprint, 1970:

'Third Impression 1970'; ISBN 0340029269; 02926 on spine; otherwise as 1st impr. [RG]

Reprint, 1975:

${ }^{* *}$ COPAC lists 1975 paperback with same ISBN

Included in omnibus with works by two other authors, 1967:

**ฟITH WOMEN IN MIND. London: Corgi paperbacks 1967.

Contents: Afternoon for Lizards by Eden; Mixed Marriage by Elizabeth Cadell; The Gallant by Charity Blackstock. [Abe]

U.S. edition as BRIDGE OF FEAR

U.S. hardback - only Severn House 1993 reissue (see above).

U.S. paperback:

Ace K-236 504, [1966 - date from Holroyd and 07973 below] 
BRIDGE | OF | FEAR | (Orig. Title: Afternoon for Lizards) | by | DOROTHY EDEN | [imprint: ace02a]

On verso-title: 'Copyright 1961, Dorothy Eden [ ... ] An ACE STAR Book, by arrangement with the author. | Printed in the U.S.A.'.

[1-4]5-190[2]pp., pale green pictorial wrappers (woman under colonnade), 175mm;

yellow(?) edges. On cover: 'FIRST | AMERICAN | PUBLICATION OF | THIS NOVEL OF |

HIGH | DRAMA AND | ROMANTIC SUSPENSE'. [RG]

Reprint:

Ace 07972 75థ; altered imprint: ace03; orange edges; otherwise as K-236. [RG]

Reprint (U.S. BIP 1974 dates 1972):

Ace 07973, 95 $\phi$ (An Ace Gothic); adds 'First Ace printing 1966' on verso-title; altered imprint: ace 04a; 44107973095 on spine; purple pictorial wrappers, new cover illus. (woman running in stream, mansion); same setting of text; orange(?) edges. [RG]

Reprint (CBI 1977 has Ace paperback 1976 \$1.50):

Ace 07977, \$1.50 (An Ace Gothic); altered imprint: ace05; 44107977150 on spine; deletes 'First Ace printing 1966' otherwise as 07973. [RG]

${ }^{\star \star *}$ Reprint?

Ace 07977 listed at $\$ 1.75$ in Crow Hollow Ace 12355-4

Reprint:

Ace 07978-4, \$1.95; altered imprint: ace08; 0-441 07978-4 195 on spine; otherwise as 07977. [RG]

Reprint:

Ace 07979-2 \$2.25; title-page and verso reset:

Bridge of Fear / Dorothy Eden | [publisher's device] | [imprint: ace09]

0-441 07979-2 225 on spine; yellow edges; otherwise as preceding. [RG]

${ }^{* * *}$ Braille editions:

AFTERNOON FOR LIZARDS. Annerley, Qld.: Queensland Braille Writing Association. [date unknown]. 4 vols of interpoint Braille. [QBWA]

AFTERNOON FOR LIZARDS. 1962. Interline Braille. 3 vols. (Held at National Library for the Blind, U.K.)

${ }^{* * *}$ Sound recordings:

AFTERNOON FOR LIZARDS. Read by Jean Elton. North Hobart: Hear a Book Service, 1977 (No.511). 5 sound cassettes. [WP]

AFTERNOON FOR LIZARDS. Read by Angela Down. Anstey, Leicestershire: Soundings, 1992. (Sounds 540). (5 sound cassettes). (also as: Isis Audio (Soundings: 5). July 1994. ISBN 1854965395).

Czech translation:

***MOST STRACHU [Translated by Zuzana Selementová]. Praha: Baronet, 2004. 216pp., $200 \mathrm{~mm}$. ISBN 8072146300. [NKC and (with pic. of cover) at http://www.baronet.cz/autoreden.html]

Dutch translation:

IK KEN MIJN MAN NIET MEER [Translated by Joh. van Rijn]. Tilburg /Utrecht: Uitgeverij Lumen, 1962. (Diamantreeks, nr.9).

[this line set right] DOROTHY EDEN | [remainder all set leff] IK KEN | MIJN MAN | NIET MEER | DIAMANTREEKS | NUMMER 9 | [line of red ornaments] | UITGEVERIJ LUMEN | Tilburg / Utrecht

Facing title-page: 'Oorspronkelijke titel | AFTERNOON FOR LIZARDS | Verschenen bij Hodder \& Stoughton, Londen [sic] | @ by Dorothy Eden / vertaling door J. van Rijn | 
[publisher's device] | [line of red ornaments] | Medeverantwoordelijke uitgever voor België: Uitgeverij Westland / Merksen' [see next]; [1-6]7-197[3]pp.; (colophon p.[200]: 'DRUK: H. TULP N.V. - ZWOLLE'); blue boards, decorated in dark blue, $214 \mathrm{~mm}$; blue pictorial dust jacket (woman in purple dress, man, couple on cliff). [WTu; date from KBN]

Flemish edition

***Merksem: Westland, 1962. 197pp. 65 fr. [IT; KBR, giving title as lk ben mijn man niet meer].

German translation:

***NACHMITTAG FÜR EIDECHSEN [Translated by Elisabeth Epple]. München:

Schneekluth, 1976. 220pp. 210mm. ISBN 3795103274. DM 24,00

New edition:

***München: Heyne, 1977. (Heyne-Bücher, Band 01/1987: Romantic Thriller). 159pp. $180 \mathrm{~mm}$. ISBN 3453111737. DM 3,80

Reprint?:

***München: Schneekluth (Dec.) 1977. ISBN 3795103274 [Amazon.de]

New edition:

***München: Droemer Knaur, 1982 (Knaur 823). 159pp. wrappers, 180mm. ISBN

3426008238. DM 6,80

Reprint ('2. Aufl.'):

***München: Knaur [date?] ISBN and other details as 1982 edition. [ÖVK gives date as 1976]

Reprint?:

***München: Heyne, Dec.1984. ISBN as 1977 edition [Amazon.de]

New edition:

***Rastatt: Pabel-Moewig, 1991 (Series: Moewig 2753: Roman 550045201). 224pp. $180 \mathrm{~mm}$. ISBN 3811827537. DM 8,80

Reprint:

${ }^{* * \star R a s t a t t: ~ M o e w i g ~ b e i ~ U l l s t e i n, ~} 1996$ (Ullstein-Buch 62914: Moewig bei Ullstein). 224pp. $180 \mathrm{~mm}$. ISBN 3811829149. DM 9,90

Also in Omnibus edition: see Omnibus section.

Norwegian translation:

${ }^{* \star *}$ ANGSTENS BRO [Translated by Rita B. Nilssen]. Oslo: Fredhøi [1976]. (Damenes roman 285). 157pp. ISBN 8204005903. Price: NKr. 8,00

Reprint:

***Bound with BRUD I FARE (Bride of Menace) by Ann Forman Barron. [Oslo]: Fredhøi, 1996. (Damenes roman 92). 158;156pp. ISBN 8204043430.

Russian translation:

***LIUBOV' V STRANE ÉVKALIPTOV [Translated by N.V. Kuz'minoī]. Moskva: Tsentrpoligraf, 2004. (Series: Tsvety liubvi Byp. 29). 221,[1]pp., 170mm. ISBN $595241088 X$ [RNL; RSL]

Swedish translation:

${ }^{* * \star}$ ĀLSKLING, VEM ĀR DU? [Translated by Makken Cullborg]. Stockholm: B. Wahlström, 1965 (Månadens roman, 2). 128,[29]pp. Price: 2:50. [Segerström; IT]

New edition:

***Stockholm: B. Wahlström, 1984. 255, [1]pp. 190mm. ISBN 9132311990. 
Whistle for the Crows. London: Hodder \& Stoughton, 1962; New York: Ace Books, 1966?

Shadow of a Witch (under pseudonym Mary Paradise). London: Robert Hale, 1962; New York: Ace, 1966?

The Bird in the Chimney. London: Hodder \& Stoughton, 1963, published in U.S.A. as Darkwater. New York: Coward, 1964.

Bella. London: Hodder \& Stoughton, 1964, published in U.S.A. as Ravenscroft. New York: Coward, 1965.

The Marriage Chest. London: Hodder \& Stoughton, 1965; published in U.S.A. (under the pseudonym Mary Paradise), New York: Coward, 1966.

Never Call It Loving. (A Biographical Novel of Katherine O'Shea and Charles Stewart Parnell). New York: Coward, 1966; published in U.K. without subtitle, London: Hodder \& Stoughton, 1966.

Siege in the Sun. (under the pseudonym Mary Paradise). New York: Coward, 1967; published in U.K. under her own name, London: Hodder \& Stoughton, 1967.

Winterwood. New York: Coward, 1967; London: Hodder \& Stoughton, 1967.

The Shadow Wife. New York: Coward, 1968; London: Hodder \& Stoughton, 1968.

Yellow is for Fear and Other Stories. New York: Ace Books, 1968; London: Severn House, 1977.

The Vines of Yarrabee. London: Hodder \& Stoughton, 1969; New York: Coward, 1969, reissued with introduction, 1978.

Melbury Square. London: Hodder \& Stoughton, 1970; New York: Coward, 1970.

Waiting for Willa. New York: Coward, 1970; London: Hodder \& Stoughton, 1970.

Dorothy Eden published nine further novels from 1970 until her death in 1982. Many of her novels also had variant titles and differing editions, see note at the beginning of Afternoon for Lizards), and many were translated into several languages where they also sold in great numbers. She also wrote under the pseudonym of Mary Paradise as can be seen in the bibliography.

\footnotetext{
${ }^{1}$ This is a shorter version of the Dorothy Eden bibliography compiled by Rowan Gibbs. As well as the title I have noted each book which has New Zealand, Pacific Island or Australian themes, plus the Bagnall reference where applicable. There is a full version of Mr. Gibbs' work deposited in the Alexander Turnbull Library, Wellington, if more detailed research is required.
} 


\section{Appendix 5}

\section{ELSIE LOCKE: SELECT BIBLIOGRAPHY ${ }^{1}$}

Books for children (but she wanted adults to read them as well.)

...

Fiction for children:

The Runaway Settlers: an historical novel for children. London: Jonathon Cape/Blackwood \& Janet Paul, 1965.

The End of the Harbour. London: Jonathon Cape/Blackwood \& Janet Paul, 1968.

Moko's Hideout. Christchurch: Whitcoulls, 1976.

The Boy with the Snowgrass Hair (with Ken Dawson). Christchurch: Whitcoulls, 1976.

Explorer Zach, (with David Waddington). Christchurch: Pumpkin Press, 1978.

Journey Under Warning. Auckland: OUP, 1983.

A Canoe in the Mist. London: Jonathon Cape, 1984.

Joe's Ruby. Whatamango Bay: Cape Catley, 1995.

Non-fiction books for children:

A Land Without a Master [NEW ZEALAND to 1840]. Wellington: Department of Education, 1962 [SJ Vol. 56, No 1, Aug 1962]

Viet-Nam. Wellington: Department of Education, 1963.

Farming in England, Government Printer, 1963

Six Colonies in One Country - New Zealand 1840-1860. Wellington: Government Printer, 1965. [1840-1860 SJ Pt 4. Spring 1964]

Provincial Jigsaw Puzzle. Wellington: Government Printer, 1965. [1860-1876 - SJ Pt 4, Aug. 1965]

The Long Uphill Climb - New Zealand 1876-1891. Wellington: Government Printer, 1966. [1876-1891, SJ Pt 4, No 1 1966]

High Ground for a New Nation - New Zealand 1891-1906. Wellington: Department of Education, 1967. [1891-1906. SJ Pt 4, No 2]

The Middle Ages. Wellington: Government Printer, 1967.

The Godwits. Wellington: Government Printer, 1968. (a school journal prepared by Elsie Locke, Lee Pledger, and the children of Standard 2, Westburn School)

The Hopeful Peace and the Hopeful War. Wellington: Department of Education, 1968. [1907-1920. SJ Pt 4, No 3]

Growing Points and Prickles: Life in New Zealand 1920-1960. Christchurch: Whitcombe \& Tombs, 1971.

It's The Same Old Earth, Department of Education, Wellington 1973

Maori King and British Queen. Buckinghamshire: Hulton Educational, 1974.

Look Under The Leaves. Christchurch: Pumpkin Press, 1975. 
Snow to Low Levels: Interaction in a Disaster. Christchurch, Whitcoulls, 1976.

Crayfishermen and the Sea: Interaction of Man and Environment. Christchurch, Whitcoulls, 1976.

A Land without Taxes: New Zealand 1800-1840. Wellington: Department of Education, 1979.

The Kauri and The Willow: how we lived and grew from 1801-1942. Wellington:

Government Printer, 1984.

Two Peoples, One Land: A History of Aotearoa/New Zealand. Wellington: Government Printer, 1988. [considered to be the first bicultural history]

The Anti-Litterbug. Nelson: Rainbow Reading Programme, 1995.

School Journal Stories: total $=34$

\section{Books for Adults:}

Gordon Watson, New Zealander 1912-1945: His Life and Writings. Wellington: NEW ZEALAND Communist Party, 1949. (Editor)

The Shepherd and the Scullery Maid. Christchurch: NEW ZEALAND Communist Party, Canterbury District, 1950

The Roots of Clover: the story of the Collett Sisters and their Families. [self-published, 1971]

Discovering the Morrisons (and the Smiths and the Wallaces): A Pioneer Family History. [self-published, 1976]

The Gaoler. Palmerston North, Dunmore Press, 1978.

Student at the Gates. Christchurch: Whitcoulls, 1981.

Mrs Hobson's Album (with Janet Paul). Auckland: AUP in association with Alexander Turnbull Library, 1990.

Peace People: a History of Peace Activities in New Zealand. Christchurch: Hazard Press, 1992.

Stick Out, Keep Left, with Jacquie Matthews (Eds). Auckland: AUP/Bridget Williams Books, 1997. [Margaret Thorn's life story]

Poetry (selected):

For Those Who Sailed: verses concerning the Wellington To Lyttelton Yacht Race. Christchurch: Clarity Press, 1951.

In Johnson, Louis, (Ed.) New Zealand Poetry Yearbook, Wellington, A.H. \& A.W. Reed: 'The Sky' Vol. 2, 1952; 'Paradise Ducks' and 'The Bracken Waste', Vol. 3, 1953; 'School Matinee - A Midsummer Night's Dream'; 'Moth', and 'The Swimming Pool At Night.'Vol. 4, 1955

The Time of the Child: A Sequence of Poems, self-published, 1954

'Said the Neighbours' in White Feathers, Hazard Press, 1991 (First published in NEW ZEALAND Monthly Review 2, no 18, November 1961, p 16) 


\section{Poems published in Here and Now:}

'Peace Without Rest', July 1951, p 36; 'Young Nation', February 1952, p 20; 'For Laszlo Rajk', June 1956, p.10

$\cdots$

\section{Poems published in the New Zealand Listener:}

'House of Retirement', March 19, 1954, p 14; 'Schools Matinee', August 6, 1954, p 11; 'Moth', October 1, 1954, p 14; 'Summer Evening: FraNew Zealand Josef', December 14, 1956, p.18; 'Never for you' September 15, 1961, p 28; 'Hedge-sparrow' July 27, 1962, p38; 'Circus Bird' October 12, 1962, p. 7

\section{Poems published in Landfall:}

'From Hospital' [3 poems: 1. 'From the Window' (1946); 2. 'First Day in the Garden' (1947); 3. 'Release' (Winter 1948) March 1952, pp. 33-35

$\cdots$

Booklets/pamphlets:

Women and Children on Relief, (Foreword as Elsie Farrelly), Unity Press, 1934

May Day and the Shorter Working Day, (as Elsie Freeman), Unity Press, 1936

Is There an Answer Without Religion? Pelorus Press, Auckland, 1951 [reprinted from Here and Now, August 1951]

View from the Lakes, [reprinted from Comment, Winter 1960]

Moving Out of Line, NEW ZEALANDCND, 1962 [reprinted from Canta, University of Canterbury Students' Association, October 18, 1962]

A Bombs Amongst the Tahitians, NEW ZEALANDCND, 1968 [reprinted from The New Zealander, June 18, 1968; [also published as a booklet, Tahiti Report: Between the Bomb Tests]

The Human Conveyor Belt: The Background to the Atom Bombs Used Against Hiroshima and Nagasaki, Caxton Press, Christchurch 1968 [reprinted from Landfall, June 1968]

Hunger and Population: a symposium, Outlook, Sydney, 1970 [with Keith Buchanan and others]

Ten Years of Achievement in the Avon Loop - 1972-1982, Avon Loop Planning Association, Christchurch, 1982

Cooperation and Conflict: Pakeha and Maori in Historical Perspective, NEW ZEALAND Foundation for Pacific Studies, Auckland, 1988 [Re-issued by the Foundation in 1990 together with lecture by Wira Gardiner as Partnership and Peace.]

Why I Collect Folk Songs - [unidentified, undated pamphlet - Angela Annabell papers, ATL: 2000-199-1/02]

$\cdots$

Chapters/essays in other books:

'The Seekers After Peace' in Canterbury Women Since 1983, Regional Women's Decade Committee, 1979

'Maori Women' in Canterbury Women Since 1983, Regional Women's Decade Committee, 1979 (authorship not identified) 
'A Note' in Edmond, Lauris, Woman in Wartime, Government Printer, 1986, p134 (authorship not identified)

'Wilhelmina Sheriff Bain' in Macdonald, C, Penfold, M, Williams, B, The Book of New Zealand Women, Bridget Williams Books, 1991

Biographical essays on Henry Monson, Mary Elizabeth Small, Abner Clough, DNZB, Vol.1, 1769-1869, Allen \& Unwin/Dept Internal Affairs, 1990

Thomson, Allan (Ed) What I Believe: the personal philosophies of twenty-two New Zealanders. GP Publications, 1993 [Elsie Locke, pp 120-133.]

Selected journal and newspaper articles:

(not including Workers' Weekly, Peoples Voice, and Working Woman, in which many articles and reports by Elsie are unsigned.)

$\cdots$

\section{Kiwi: annual magazine of Auckland University College (as Elsie Farrelly)}

'The Student Responsibility', 1932 ('by E.F.')

'And Now?' 1933

[HER MAIDEN NAME WAS FARELLY - HER FIRST HUSBAND WAS FREEMAN]

$\cdots$

New Zealand Communist Review (as Elsie Farrelly, then Freeman)

'The Party and the Working Woman', December, 1934, pp 11-16

'Women Against Fascism: the Communist Party and the Women', April, 1936, pp 21-23

...

\section{Woman To-Day [HOW IT WAS SPELT] (as Elsie Freeman)}

'Towards Happier Parenthood', April 1937, pp 10-11

Untitled: about food value of oranges, June 1937, p 72

'Peace But How', Nov 1937, p 176-7

'Women and the Labour Movement: a talk with Mrs H.E. Holland', January 1938, pp 224-5

'Spain's Women and Children: interview with Sister Mary Lowson' March 1938, pp 280281

'Can The Fascists Be Stopped', April 1938, p 300

'Socialism - a reply to Nina A.R. Barrer, M.A.', May 1938, p38

'The Defence of Peace', October 1938, p 11

'On Tour For 'Woman To-Day', January 1939, p13

Editorial: 'A Scandal Crying Aloud To Heaven' (re Spanish Civil War and return of nurses) February, 1939, p.1

'Have We Any Troubles?' February, 1939, p.12

'On Tour for 'Woman To-Day', March 1939, p 13

'I Travel for 'Woman To-Day', April 1939, pp 12-13

'I Travel for 'Woman-Today', May 1939, pp 12-13

'I Travel for 'Woman To-Day', June 1939, p 14-15 


\section{In Print: a magazine of Marxism (as Elsie Locke)}

'Municipal Affairs and the Labour Movement', October, 1944, pp 10-13

'Religion and Social Change', November, 1944, pp 21-25

'New Zealand's Foreign Policy', February, 1945, pp 28-32

New Zealand Labour Review (incorporating In Print)

'S.O.S. - Save Our Soil', May, 1946, p9

'Why People Live in Towns' May, 1946, pp 17-18

'The Road to a Healthy Nation', August 1946, pp 23-30

'The Road to a Healthy Nation', (contd.), September, 1946 pp13-16

'Remembering' (poem), January, 1947 p.19

'Do Communists Talk Jargon', March, 1947 pp 19-23

'The Soviet Literary Controversy', August, 1947, pp 26-30

'Civic Pride', November, 1947, pp 34-36

'Communism is not 'Russian", February, 1948, pp. 27-29

'Does Man Conquer Nature', May 1950, pp 21-25

'Psycho-Analysis and Logic', VOL. VII, No. 4, August 1951, pp.30-32

'Some Thought on a People's Culture', April 1952, pp 19-24

'Spotlight on Democratic Centralism', August, 1956, pp.4-10

\section{New Zealand Listener}

'O' to be in New Zealand. Confessions of a Nonentity About to Remain at Home', April 26, 1946, pp 8-9.

'Overworked Mother Speaks Out', April 8, 1949, pp16-17

'Old People Alone', July 22, 1949, pp 14-15

'Mother Steps Down', September 11, 1953, p.8

'Crime Comics - Outlet or Incitement', September 3, 1954, p.8

'Doing-Doing-Done! December 7, 1956, p.8

'The Apricot Day' (short story), September 18, 1959, pp 22-23

'The truth about Labour Day', October 15, 1973, p 19

'Places of Discovery', September 25, 1976, pp 16 - 17

'Tessa on Her Own', (children's story in 'Junior Listener') May 15 1982, pp94-95

'The Magic Spark' (children's story), October 15 1983, pp 76-77

'Institution or Community', January 7, 1984, p.16

'Spirited Struggles' -review of Break Down These Bars by Jim Edwards, September 19, 1987, pp 61-62

'Sunny Side Up' - review of Standing in the Sunshine edited by Sandra Coney, October 9, 1993, pp 46-47 


\section{Here and Now}

'The Status of Being Useful,' Jan-Feb 1951, pp 35-37

'Writers in Conference', June 1951, pp 27-28 [EXTRACT REF]

'Is There an Answer Without Religion?' August 1951, pp 23-25

'Beyond the Child's Front Gate', August 1952, pp 21-22

\section{Landfall}

'Looking for Answers', December 1958, pp 335-355 [SHE WON THE FIRST

KATHERINE MANSFIELD ESSAY AWARD IN 1959 FOR THIS, SHARING THE AWARD WITH MAURICE DUGGAN FOR HIS STORY 'THE DEPARTURE']

'Keep the South Free,' December 1962, pp 387-392

Review of Harry Holland: militant socialist by P.J. O'Farrell, September 1965, pp 303-307

'The Human Conveyor Belt', June 1968, pp 201-220

Comment

Locke wrote many social comment articles over several years

\section{Turnbull Library Record}

'What Hope for a Sane and Humane World', Vol. 24, No. 2, October 1991, p 97-111

'About Woman Today', Vol. 29, 1996, pp 47-58

[She also contributed to numerous other journals, including $\mathrm{Te}$ Ao Hou and Te Karanga]

\section{Radio Broadcasts:}

[NUMEROUS: The first two were written when she was in hospital for two years - 1946-48 with spinal tuberculosis]:

${ }^{1}$ FROM MANUSCRIPT: Looking for Answers: A Life of Elsie Locke by Maureen Birchfield, published by Canterbury University Press, 2009. 


\section{Appendix 6}

\section{RUTH GILBERT: BIBLIOGRAPHY}

Lazarus and Other Poems AH \& AW Reed, Wellington, 1949.

Reviews:

Anderson, D.M. Landfall, Vol.4, No.2 (ie No.14) pp162-163, June 1950.

Hart-Smith, W. NEW ZEALAND Listener, 10 March, 1950.

The Sunlit Hour Allen \& Unwin, London, 1955.

Reviews:

Stead, C.K. Landfall, 38: pp151-154, June 1956.

Here and Now pp29-30, May 1956.

The Luthier: Poems Reed, Wellington, 1966.

Collected Poems Black Robin, Wellington, 1984.

Reviews:

Edmond, Lauris. NEW ZEALAND Listener, 3 November, 1984.

Early Poems: 1938-1944 Cultural and Political Booklets, Wellington, 1988.

More Early Poems, 1939-1944, \& Five Later Pieces, with an Appendix Cultural and Political Booklets, Wellington, 1988.

Mysterious Eve: a Filmscript poems by Ruth Gilbert; story by F.W. Nielson Wright, Cultural and Political Booklets, Wellington, 1989.

\section{Reviews:}

Mintrom, Michael. Dominion, p9, 1 April, 1989.

Breathings: Poems with drawings by Deidre Mackay, Original Books, Wellington, 1992.

Dream, Black Night's Child: Poems with drawings by Deidre Mackay, Original Books, Wellington, 1993.

Complete Early Poems, 1938-1944: with six later pieces Original Books, Wellington, 1994.

Gongyla Remembers: Poems with drawings by Deidre Mackay, Original Books, Wellington, 1994.

Complete Sappho Poems of Ruth Gilbert (includes Breathings, Dream, Black Night's Child, and Gongyla Remembers. Original Books, Wellington, 1998.

\section{About Ruth Gilbert ${ }^{2}$}

French, Phyllis Ann. 'Twelve women poets of New Zealand: imperatives of shape and growth'. Thesis, University of Texas, 1967.

Needlam, John. 'Recent poetry and Coleridgean principles'. JNEW ZEALANDL: Journal of New Zealand Literature 3 p35-56, 1985.

Else, Anne. 'Not more than a man nor less: the treatment of women poets in Landfall, 1947-1961.' Landfall 156: p431-446, Dec, 1985. 
${ }^{1}$ F. W. Nielsen Wright provided me with much of the information to complete Ruth Gilbert's bibliography

\footnotetext{
${ }^{2}$ Recent international recognition of Ruth Gilbert's work.
}

As a recent indication of the on-going interest in Ruth Gilbert's work the information below is from the English Department of the University of Toronto, Canada website,

http://rpo.library.utoronto.ca/poet/537.html. This indicates international recognition of her work is growing (see also the correspondence between Dr. Nielsen Wright and the American poet Cameron La Follette in Appendix 8).

Selected Poetry of Ruth Gilbert (1917-)

\section{from Representative Poetry On-line}

Prepared by members of the Department of English at the University of Toronto

from 1912 to the present and published by the University of Toronto Press from 1912 to 1967.

RPO Edited by lan Lancashire

A UTEL (University of Toronto English Library) Edition

Published by the Web Development Group, Information Technology Services, University of Toronto Libraries

(c) 2009, Ian Lancashire for the Department of English, University of Toronto

Index to poems
1. And There Shall be No More Death
2. By Bread Alone
3. The French Horn
4. In Old Age
5. Lot's Wife
6. Still-born

\section{Notes on Life and Works}

Ruth Gilbert was born at Greytown, New Zealand, in 1917, daughter of Florence Margaret (Carrington), a music teacher, and Henry George Gilbert, a Prebyterian minister and violin-maker. In 1945 she married John B. Mackay (1918-95), a doctor, and has four children. Her poetry appeared first in magazines and anthologies in Commonwealth countries and then in ten personal collections published in New Zealand and England. In the 1980s she turned to reading Sappho in the original Aeolic dialect and went on to publish three volumes of verse honouring her memory. Ruth Gilbert's honours include the Jessie Mackay Memorial Award for verse (three times) and she has served as President of New Zealand P.E.N. and the New Zealand Women Writers Society. She lives in retirement at Motueka.

- $\quad$ Gilbert, Ruth. Lazarus and Other Poems. Wellington, New Zealand: A. H. and H. W. Reed, 1949.

- $\quad$--. The Luthier: Poems. Wellington, New Zealand: Reed, 1966.

- $\quad$--. The Sunlit Hour: Poems. London: Allen and Unwin, 1955.

- $\quad$--. Collected Poems. Wellington, New Zealand: Black Robin, 1984.

- $\quad$--. Early poems, 1938-1944. Wellington, New Zealand: Cultural and Political Booklets, 1988.

- $\quad$--. Breathings: Poems. Aotearoa: Original Books, 1992.

- $\quad$--. Dream, Black Night's Child: Poems. Aotearoa: Original Books, 1993. 1994.

--. Complete Early Poems, 1938-1944, with six later pieces. Aotearoa: Original Books,

--. Gongyla Remembers: Poems. Aotearoa: Original Books, 1994. 
- $\quad$--. Selected Poems 1941-1998. Ed. Ruth Gilbert and Derek Bolt. Wellington, New Zealand: Original Books, 2008.

Biographical information

Given name: Ruth

Family name: Gilbert

Birth date: 1917

Education

Hamilton High School

Otago School of Physiotherapy to 1938

Occupation: physiotherapist

Residence: Motueka, New Zealand

First RPO edition: 2009

F. W. Nielsen Wright has published Ruth Gilbert, an Account of her Poetry: An Interpretative Study (Wellington, N.Z.: Cultural and Political Booklets) in 1985. I am grateful for his assistance in obtaining copies of Gilbert's publications.

$\underline{\text { Ian Lancashire, Department of English, University of Toronto, Canada. }}$ 


\section{Appendix 7}

\section{JANET FRAME: BIBLIOGRAPHY}

The Lagoon and Other Stories. Christchurch: Caxton Press, 1951.

Owls Do Cry. Christchurch: Pegasus Press, 1957.

Faces in the Water. Christchurch: Pegasus, 1961.

The Edge of the Alphabet. Christchurch: Pegasus Press, 1962.

Snowman, Snowman: Fables and Fantasies. New York: G. Braziller, 1962.

Scented Gardens for the Blind. Christchurch: Pegasus Press, 1963.

The Adaptable Man. Christchurch: Pegasus Press, 1965.

Reviews of The Adaptable Man

[This collection of reviews and articles for her 1965 novel The Adaptable Man illustrates Frame's worldwide audience and influence, both near the time of publication and following through the years to the 1990s. I have only given one example, but each of Janet Frame's titles in her bibliography follows much the same pattern.]

Time 86: 90; 6 Aug 1965.

Sheed, W. New York Times Book Review 70: 4; 8 Aug 1965.

Tracy, H. New Republic 153: 20; 11 Sept 1965.

Manville, W. H. Book Week p.19; 3 Oct 1965.

New Yorker 41: 233; 9 Oct 1965.

Observer p.28; 17 Oct 1965.

Hemmings, F. W. New Statesman 70: 613; 22 Oct 1965.

Hall, David. Listener 53(1367): 19; 17 Dec 1965.

Choice 2: 579; Nov 1965.

Hall, J. Books and Bookmen 11: 31; Feb 1966.

Joseph, M. K. Landfall 20: 92-5; Mar 1966.

Graham, D. Journal of Commonwealth Literature 4: 148-50; Dec 1967.

Evans, Patrick. Landfall 25: 448-55; Dec 1971.

Michael Rogers. Library Journal 117(12): 132; Jul 1992

New \& Notable 10(3): 1-5; July 1993.

Arnold, Sandra. Press Sup.p.10; 28 Aug 1993.

Cooper, Ronda. Metro 146: 131-132; Aug 1993.

Wilkins, Damien. Listener 140(2793): 52-53; 16 Oct 1993.

The Reservoir: Stories and Sketches. New York: Braziller, [1963]; Christchurch: Pegasus Press, 1966.

The Pocket Mirror : Poems. New York: Braziller, 1967.

A State of Siege. Christchurch: Pegasus Press, 1967.

Mona Minim and the Smell of the Sun. New York: Braziller, 1969. 
Rainbirds. London: W.H. Allen, 1968. (Published in the U.S.A. as Yellow Flowers in the Antipodean Room. New York: Braziller, 1969).

Intensive Care. New York: Braziller, 1970.

Daughter Buffalo. Wellington: Reed, c1972.

Living in the Maniototo. New York: Braziller, 1979.

To the Is-Land. London: Women's Press in association with Hutchinson Group (N.Z.), 1983.

You Are Now Entering the Human Heart. Wellington: Victoria University Press, 1983.

An Angel At My Table. Auckland: Hutchinson, 1984.

The Envoy From Mirror City. Auckland: Hutchinson, 1985.

Reviews

The Carpathians. Auckland: Century Hutchinson, 1988.

Autobiography. Auckland: Century Hutchinson, 1989.

Janet Frame, Stories and Poems. Auckland: Vintage, Random House New Zealand, 2004.

Towards Another Summer. Auckland: Vintage, Random House New Zealand, 2007.

\section{Articles by Janet Frame}

'Waiting for daylight.' Landfall 39: 196-197; Sept 1956. Poem.

'The dead.' Landfall 42: 148; June 1957. Poem.

'The joiner; The senator had plans; Scott's horse.' Landfall 18: 209-211; Sept 1964.

Poems.

'Beginnings.' Landfall 73: 40-47; Mar 1965.

(Tells of her early interest in writing poetry, her time at primary school, early publication in the local newspaper, and her use of the library. Traces the ups and downs of her early career, the people who helped, and the novels she published.)

'The bath.' Landfall. 75:25-230; Sept 1965. Short story.

'The boy's will.' Landfall 80: 314-323; Dec 1966. Short story.

'Janet Frame on Tales from Grimm.' Education 24(9): 271975.

(Early reading series by New Zealand writers.)

'Departures and returns.' In: Writers in East-West Encounter: New Cultural Bearings. Edited by G. Amirthanayagam. London: Macmillan, 1982. pp.85-94. 
'A last letter to Frank Sargeson.' Islands 1(1): 17-22; July 1984. With Anthony Stones. (Presents a memorial to the late Frank Sargeson, written as a letter to him. Gives details of the years Frame lived in a hut on Sargeson's property, and describes his social life, visiting writers, and how he helped Frame.)

'To dine in fancy restaurants.' New Statesman 110: 29-31; 11 Oct 1985

(Excerpt from autobiography).

'Frame likes her double.' Dominion p.16; 16 May 1989.

'Beginnings.' In: Writers on writing: an anthology. Edited by Robert Neale. Auckland: Oxford University Press, 1992. First published in Landfall. 19(1): 40-47; 1965.

'An exhibit in the pre-Columbian room, Dumbarton Oaks Museum, Washington.' Sunday Star Times Sup.p.4-5; 2 Jan 2000.

(Provides a brief profile of the writer and presents a poem commissioned from her to mark the new millennium.)

'Three poems by Janet Frame.' Listener p.40; 28 Aug 2004.

(Previously unpublished poems, 'The End'; 'The Happy Prince'; 'Eater of Crayfish'.)

\footnotetext{
${ }^{1}$ Source: Website of Auckland University Library, plus the Official Janet Frame Website (see general bibliography).
} 


\section{Appendix 8}

\section{E-mail correspondence between Niel Wright and Cameron La Follette. ${ }^{1}$}

The letter below received on the $9^{\text {th }}$ December, 2008, from Cameron La Follette in North America requesting a book from Mr. Rowan Gibbs' website, ESAW Books, and asking for further information regarding Ruth Gilbert's shows two things: firstly, that there is international interest in New Zealand poetry and, secondly, the difficulties involved in gaining such information through the normal literary and academic channels if the poet or writer is not on the 'official' list of 'authorised' writers. The letter reads as below and is followed by Rowan Gibbs' reply regarding the availability of Ruth Gilbert's work and a note by her publisher, Niel Wright. This is a good example of the importance of private publishers and scholars such as Wright and Gibbs, as is shown throughout this thesis.

Sent: Tuesday, December 9, 2008

Subject: Ruth Gilbert's poetry

\section{Hi, Mr. Gibbs,}

Thank you very much. I am going to take the opportunity of your email to ask about Ruth Gilbert's work, because maybe you know more about how to locate some of it at a decent price; and also because you apparently know Mr. Wright. I live in the US, as you can see. I saw three of Gilbert's poems in a New Zealand anthology from 1952. I tried to find a book of her poetry through my library, which does interlibrary loans throughout the English-speaking world. Not one library in the US and Canada had any books of her poetry. I tried the internet, and there is none of her poetry on the internet either, even at fairly comprehensive sites like Representative Poetry Online (RPO). [this situation has since changed: see Appendix 6 for Ruth Gilbert's recent entry on RPO website from the University of Toronto] Nor could I find any copies of anything for sale for awhile; then I found your listing. From what little I have seen, her poetry is magnificent. Why is it so astoundingly, totally unavailable, even (apparently) in NEW ZEALAND, not to mention here?

I saw in internet searches that Mr. Wright has done some work on Ruth Gilbert. If he would be willing to be in touch with me via email, I would appreciate it greatly. I want to locate at a decent price, if it is possible at all, a copy or (preferably) two, of her Collected Poems, published in 1984. I'd have one copy for me, and l'd give the other one to my local library. Then it would show up on the Worldcat internet catalog used by all libraries, so they could find it. And there would be one copy of her work in the US and Canada. Better than none! I'd also like to find out more about Ruth Gilbert, as I have not found one single scrap of information, other than a listing of the award she received from the Queen in 2002 "for services to poetry." Thank you very much for any help you are able to give and thanks to Mr. Wright, if he is willing to get in touch with me about this.

All the best,

Cameron La Follette ${ }^{2}$

\section{Rowan Gibbs' reply:}

$\mathrm{Hi}$

Many thanks for your order. I've just phoned Niel Wright, the friend of Ruth Gilbert who prints and publishes this, and he will print off a copy tomorrow; we will get it posted as soon as we get it, certainly early next week:

Best wishes

Rowan Gibbs 


\section{From Cameron La Follette to Niel Wright}

Sent: Wednesday, December 10, 2008 9:55 AM

Subject: Ruth Gilbert's poetry

Hi Niel,

This is indeed my proper email address, and thank you so much for writing to me. I am overjoyed to find that Ruth Gilbert is still alive and well at ninety-one. If you think it appropriate, please give her best regards from me - an unknown admirer from far away. It is wonderful to read a poet who writes so exquisitely. All the other poets whose work I admire (Yeats, Keats, Millay, Pope, etc.) have all been dead for a long, long time. I love knowing that an excellent poet is still living among us. I will work on getting more of Ruth Gilbert's poetry, a bit at a time. As you mention, postage is the big impediment; I am unfortunately not wealthy.

I ordered Luthier Poems from another bookstore in New Zealand, and so it will be coming to me also. I did see the Sappho poems for sale also-your work, I would suppose. I did not buy those at this point, because I was not sure what they were, whether translations or her original work. I am familiar with Mary Barnard; I mean, I know her name, and know she is the well-known translator of Sappho. I do not know where her papers ended up, but I might be able to find out. I live in Salem, Oregon, which is a not-very-important town in Oregon, though it is the state capitol. I go to my library often, and one of the research librarians is my friend. He could probably find out for me without too much trouble.

I just returned the New Zealand anthologies I was studying to the library, and I don't remember the name of the one I mentioned to you. But I can find out by looking at my record of books checked out. It was done by Oxford University Press, I seem to recall. One of her poems in there was entitled (I think) "Li Po," about the Chinese poet. I also looked at a similar Penguin anthology of New Zealand verse, edited by Alan Curnow. It did not have Ruth Gilbert in it at all.

I do have internet access, and if you have some articles about Ruth Gilbert, I would be interested in seeing them. If you do republish The Sunlit Hour privately, please let me know how much it would cost, and I will see whether I could afford it. I understand the poetry problem in New Zealand as you describe it - by the way, New Zealand is a country I have always passionately wanted to visit. I am horridly ignorant about it, but have always wanted to come there. Anyway, I wonder if Ruth Gilbert has been sidelined in part because she is a traditional poet? Most poetry in the English-speaking world these days, and for the last 100 years, has been "modern" poetry, not written in any traditional forms.

In the US at least, modern poets control all fellowships, prizes, anthologies, residencies, poetry associations and poetry/creative writing programs at universities. This is true for public money as well as private money. Traditional poets, the few that there are, have almost no outlets at all, unless they do things entirely independently. The situation is actually rather ridiculous.

There's an astounding amount of poetry in the US - tons and tons of chapbooks published every year-but nobody reads it outside of the modern poetry circles; there are more and more prizes and words of praise, but the poetry is not of good quality, and most people don't bother with it. The whole situation makes me sick at heart, and that is why I was overjoyed to see that Ruth Gilbert writes so beautifully, and is an honoured poet in New Zealand.

Thank you greatly for your help—and your support of Ruth Gilbert over the years. If not for references to your work over the internet, I wouldn't have been able to find anything out about her at all. Here it is $1 \mathrm{pm}$ on tuesday. The internet clock tells me that in Wellington it's 9 am on wednesday, so I guess you're 21 hours ahead of us, and you're already in tomorrow. Hmmm, there's a curious thing to think about!

Best, 


\section{Cameron}

\section{Hi Cameron,}

I never know what the time is in Oregon. It is early afternoon on the 9th here. So I imagine you're sound asleep. The long and short of it is that you are now in touch with the right people for your interest in Ruth's poetry. It will just be a matter of getting through the process. Cost of mailing is the biggest impediment. I would be interested to know the name of the anthology you date 1952, if you still have that information. It may be one I don't know of. There is a big book called CONTEMPORARY POETS OF THE ENGLISH LANGUAGE (1970) published in US in which Ruth Gilbert gets a write up but under her married name Mackay.

Also in the book is Mary Barnard, the translator of Sappho, who was well known in Oregon. She and Ruth Gilbert were close friends in Mary's last decade after I got the two in touch with one another. Mary Barnard has since died some years ago. I would like to know where her papers have come to rest. The correspondence with Ruth Gilbert and perhaps some of Ruth's books could be among them. Rowan Gibbs will mail you Ruth's COMPLETE EARLY POEMS (none in COLECTED POEMS) this week. I also published Ruth's late poems as COMPLETE SAPPHO POEMS, (again not in COLLECTED POEMS).

So I can supply that one too. I have asked Derek Bolt to talk to Ruth Gilbert about doing photocopied reprints of her other books of poems. I have wanted to do her 1956 book THE SUNLIT HOUR that way, because it had a lot of material in it that did not make COLLECTED POEMS. I will do something about this as a private edition for now. Beyond that I have published extensively on Ruth Gilbert in what I describe as scholars' resource books, just background information. A good deal of this material can be transmitted by internet if you are interested and have the facility to receive it by internet.

I've admired Ruth Gilbert's poetry since 1949 when she first appeared in book form. I have been a close associate of hers since 1965. If you wonder why so little is available about her, the simple answer is that New Zealand is a small country where poetry is dependent on state funding/state funded academics to get a high profile. But in 1951-1952 there was a tremendous ruckus in academic circles here in New Zealand that left a lot of people standing outside the academic/state administration magic circles. Ruth Gilbert has always had influential friends and editors etc and her reputation stands very high but as you notice there is little trace of her work as a poet to be found wherever you might expect to find it, simply because she and her current friends are not moving in the right circles. It is actually too silly for words, but that's how it goes in a country one of my friends last night acknowledged is a sort of Alice-in-wonderland where nothing is what it seems.

Best wishes for now, Niel Wright

\footnotetext{
${ }^{1}$ Niel received an order from Cameron for a copy of Ruth Gilbert's poetry which she saw for sale on the ESAW Books site on Abebooks and includes her original request to Rowan Gibbs for the book.

2 "Cameron La Follette's poems reveal an elegance of phrase and form matched only by her love of place: a Pacific Northwest both real and imagined; a Celtic world both found and lost."
} 
Cameron La Follette works as an environmental land use advocate, and is the co-founder of Salem, Oregon's Classic Poetry Group, whose members read and study older poetry. She lives and works in Salem, Oregon. 


\title{
Appendix 9
}

\section{New Zealand Poetry Checklist ${ }^{1}$}

\section{A CHECKLIST OF ANTHOLOGIES AND CRITICAL BOOKS ETC PUBLISHED IN 1945-1970 REGARDING AOTEAROA POETRY ${ }^{2}$}

\author{
1945 Poetry
}

Anvil - (1945-1946) literary journal edited by Rosemary Seymour

Australian Poetry 1944 - edited by R.G. Howarth

Arts in New Zealand Yearbook 1945

A Book of Australasian Verse - edited by Walter Murdoch

Aunt Daisy's Second Scrap Book

A Book of New Zealand Verse 1923-1945 - edited by A. Curnow

Chapbook (1945-1950) - literary journal

Interlude - the story of British Prisoners of War

New Zealand - a colony of the mind by E.H. McCormick

New Zealand New Writing No 4 - (1945) edited by I.A. Gordon

Poetry in New Zealand - by A.R.D. Fairburn in 'Arts in New Zealand Yearbook 1945'

Quairs of Quotations - anthology New Zealand Federation of University Women

Songs, Hakas and Choruses $-4^{\text {th }}$ edition Timaru Boys' High School

Timeless World - by M.H. Holcroft

The Ultava Still Sings - anthology of Czech poetry in translation by F. Ost and R. Meek

1946 Poetry

An Australasian Anthology - $3^{\text {rd }}$ edition edited by P. Serle

Arts in New Zealand Yearbook 1946

Creative Writing in New Zealand - by J.C. Reid

Encircling Seas - by M.H. Holcroft

Grounds for Mild Assurance - by E.H. McCormick in 'Arts in New Zealand Yearbook 1946'

Literature and Landscape in New Zealand - by A.E. Mulgan reprinted from 'New

Zealand Geographer' Vol 2 No 1 April 1946

Modern Australian Poetry - edited by H.M. Green $2^{\text {nd }}$ edition 1952

New Zealand Literature - newspaper articles on writers, awards and censorship 1946-

1968 clippings: National Library reference q820 NEW 1946-68

Poems from New Writing 1936-1946 - with foreword by J. Lehmann

Poetry in New Zealand - by J.K. Baxter in 'Arts in New Zealand Yearbook 1946'

Poets and Printers - edited by W. Cawood poems published by Form 2c Tweedsmuir Intermediate School Invercargill

Poets of Australia - selected by G. Mackaness

Polynesian Literature, Māori Poetry - by J.C. Andersen

Prose and Verse - edited by D. Cowie and J. Mountain

Witness to the Stars - anthology of Australasian verse by Catholic poets edited by P.L.

Grano

1947 Poetry

An Introduction to English Literature to 1947 - by J.A.E. Mulgan and D.M. Davin

Landfall 1947

Poetry in New Zealand - by W. Hart-Smith in 'Arts in New Zealand Yearbook 1947' Writing in New Zealand No 4 - by E.H. McCormick, New Zealand Education Dept. School Publications 
1948 Poetry

Bookie - a new miscellany Nag's Head Press No 1

Creative Problems in New Zealand Writing - M.H. Holcroft

The Flesh and the Spirit - literary essays by D. Stewart

Poetry in New Zealand - by H.W. Wells in 'Voices' No 133

Quill 1948

Verse Journals 1948 - (set for various grades) New Zealand Dept of Education

Voices - a quarterly of poetry Spring 1948 number 133: Commonwealth issue

Arts in New Zealand Yearbook No 4 (1948)

1949 Poetry

A Centennial Treasury of Otago Verse - edited by A.E. Currie

Education - a magazine for Teachers Vol 2 No 2 May 1949 article by P H in effect explaining what the 'Verse Journals' were about

Here and Now - three issues to January 1952

Hilltop - magazine 1949

Human Values and Literature - by H.W. Rhodes

New Zealand National Review (1917-1951) - under editor Noel Holmes from mid 1949

published Aotearoa writers including Louis Johnson

The Old Clay Patch - a collection of verses written in and around Victoria University

College $3^{\text {rd }}$ edition 1949

Verse Journals 1949 - (set for various grades) New Zealand Dept of Education

Arts in New Zealand Yearbook No 5 (1949)

Throughout the 1940's very small amount of poetry in school publications New Zealand

Dept of Education

English Standard IV

English Form II

1950 Poetry

Arachne - magazine 1950-1951

Arts in New Zealand Yearbook No 6 (1950)

A Book of Australian and New Zealand Verse - chosen by

W. Murdoch and A. Mulgan

Bookie - a new miscellany Nag's Head Press No 2

Discovered Isles - by M.H. Holcroft

Eight Quills - edited by Laura May Strachan and others

New Zealand Farm and Station Verse 1850-1950 - $2^{\text {nd }}$ edition 1967

Plain Words About Poetry - by A.R.D. Fairburn in 'Arts in New Zealand Yearbook No 6'

Pot-Pouri - of poems and prose, by students of W.E.A. Creative English Class, April to

August 1950 Christchurch Centre

Talent - a selection of the best new writing in Australia and New Zealand includes verse.

Freelance Writers Federation, Sydney Turnbull Library reference 820.81950

Verse 1950

1951 Poetry

Arts in New Zealand Yearbook No 7 (1951)

A Book of New Zealand Verse 1923-1950 - revised edition edited by A. Curnow

The Caxton Press - some impressions and a bibliography by

P. Lawlor

Kiwi Youth Sings - compiled by C. Bollinger

Jindyworobak Anthology 1951 - Trans-Tasman Issue edited by

G. Rawlinson and W. Hart-Smith 
Moa on Lambton Quay - Animal, vegetable and funereal verse

Recent Trends in New Zealand Poetry - by J.K. Baxter

The Year's Writing - by J.C. Reid in 'Arts in New Zealand Yearbook No 7'

1952 Poetry

The Caxton Press Book List

Contemporary Verse - selected by J. Stevens: primary school bulletin vol 6 no 131952

New Zealand Dept of Education

New Directions in Prose and Poetry - edited by J. Laughlin

Poems 1952 - Wellington Technical College (Wellington High School)

Poems Unpleasant - by J.K. Baxter, Louis Johnson, Anton Vogt

Poets' Quest - selected by E.A. Southwell

A Select Bibliography of New Zealand Verse and Some Related Writing 1920-1952 by P. Alcock

Thirteen New Zealand Poets - an anthology of verse edited by Robert Thompson

Te Ao Hou 1952-1976 - quarterly

1953 Poetry

Marche de France - Courrier Litteraire d'Outremer No 16 Fevrier 1953 article by Louis Johnson on New Zealand poetry (in French)

New Zealand Literature 1953 - J.K. Baxter on poetry, Victoria University of Wellington

Adult Education Dept. Turnbull Library reference 820.9 [1953]

Poems - edited by J.F. Bennett offprint from 'OUTLOOK' Presbyterian Church NEW

ZEALAND magazine January-June 1953

POEMS - an anthology of New Zealand women writers

Rhyme, Rhythm and Reason - an introduction to verse appreciation for schools by Edna E. Willton, author of 'ADVENTURE IN VERSE' NEW ZEALAND edition 1953

\section{Poetry}

Australian Poetry 1954 - selected by R. McCuaig

A New Literature of the South Pacific - by Phillip Wilson

(1922-) reprint from 'AMERICAN QUARTERLY' Vol 6 no 1 Spring 1954 Turnbull Library reference 820.91954

numbers - literary magazine ten issues 1954-1959

1955 Poetry

Australian Poetry 1955 - edited by J. McAuley

Best Poems of Borestone Mountain Poetry Awards 1955-1976 - 1955-1976, Palo Alto California

Junior Song Book - with music New Zealand Dept of Education

Fire and the Anvil - by J.K. Baxter ( $2^{\text {nd }}$ edition 1960)

New Zealand Books - by J.C. Reid. Turnbull Library reference 820.4

Serendipity - poems and prose, by students of W.E.A. Creative English Class, April to

August 1955 Christchurch Centre

The Voice of a Silent Land: New Zealand Writing - by E.H. McCormick: reprinted from 'BOOKS ABROAD' summer 1955 Turnbull Library reference 820.9 [1955] $p$

Wellington in Verse and Picture - selected by P. Lawlor

( $2^{\text {nd }}$ edition)

Writing in Auckland - a selection over a century by J.C. Reid

1956 Poetry

An Anthology of New Zealand Verse - edited by R. Chapman and J. Bennett Colonial Ballads - edited by $\mathrm{H}$. Anderson ( $2^{\text {nd }}$ edition 1962 enlarged)

Experiment - magazine of the Literary Society of Victoria University of Wellington 19561959 
Institut fur Auslandsbeziehungen - Januar/Februar 1956, 6 Jahrgang Numer 1 / 2 article by Asher on New Zealand poets

New World Writing - Tenth Mentor Selection

The Sonnets in Australasia - a survey and selection by L.I. Lavater (1867-1953) -

revised and enlarged edition

Spring Fires - a study of New Zealand writing by O.E. Burton (1893-) Turnbull Library reference 820.9 [1956]

Verse for You - a collection of verse for junior forms compiled by J.G. Brown (New

Zealand pages 3-45)

The Wide Brown Land - edited by J.S. \& G. Mackaness

1957 Poetry

Mate - literary magazine 1957 - approaching 20 issues by 1970

The Night Shift - poems by J.K. Baxter, Charles Doyle,

Louis Johnson

1958 Poetry

A.R.D. Fairburn: A Bibliography - by Olive Johnson

Goldrush Songster - anthology by H.McD. Anderson (1927-)

Image - literary magazine 1958-61 edited by Robert Thompson

Poetry Harbinger - introducing A.R.D. Fairburn and Denis Glover

A Thought for the Day - from Aunt Daisy's scrapbook: mainly verse

3 Poets - poems by P. Bland, J. Boyd, V. O'Leary

Verse for You Book 2 - compiled by J.G. Brown

Verse for You Book 3 - a collection of verse for junior forms compiled by J.G. Brown

1959 Poetry

An Adventure in Asian and Australian Writing Span - edited by

L. Wigmore

A Book of Elephant Extracts - chosen by D. McEldowney

A Book of Poetry - chosen by W.M. Smith

Further Thoughts for the Day - from Aunt Daisy's scrapbook - mainly verse

Further Poems of Spirit and Action - selected by W.M. Smith

Gorse in the Gutter - verse by D. Barrier and others

A Thought for Every Day - from Aunt Daisy's scrapbook -

mainly verse

Songs We Sang - compiled by L. Cleveland

1960 Poetry

Commonwealth Literature - London 1960 includes Bertram on 'LANDFALL'

Good Morning Thoughts - from Aunt Daisy's scrapbook -

mainly verse

The Guinness Book of Poetry 1958/59 - compiled by J. Lehmann

'Landfall in Unknown Seas' - by J.A.W. Bennett London BBC 1960

New Zealand Literature - a survey by E.H. McCormick (1906-) review by Horst Oppel Marburg reprint from BRITANNICA: festschrift fur H.M. Flasdieck Heidelberg. Turnbull Library reference 820-9 1960

New Zealand Universities Literary Yearbook 1960

Matika - verse 1960 edited by H. Patterson

The Penguin Book of New Zealand Verse - edited by A. Curnow

Voyager Poems - edited by D. Stewart

Writing in New Zealand: Poetry in New Zealand - edited by

W.H. Oliver: NEW ZEALAND Dept. of Education School Publications Branch 
1961 Poetry

The Albermarle Book of Modern Verse Vol 2 - edited by

F.E.S. Finn

Argot - literary magazine issues 1-23 between 1961 and 1970, a few more later

The Commonwealth PEN - edited by A.L. McLeod

Literature in New Zealand - by J.C. Reid

In a Child's Mind - anthology Tawa School

The Kiwi Laughs - edited by J.C. Reid

Modern English Writers - compiled by M. Judine and M. Gratia

New Zealand in Colour - text by J.K. Baxter $\left(2^{\text {nd }} \& 3^{\text {rd }}\right.$ edition 1962)

A Secret Feeling - Karori West Normal School

Wren With Little Quill - a miscellany by M.G. Fenton etc

1962 Poetry

Good Morning Everybody - thoughts from Aunt Daisy's scrapbook mainly verse

Great Days in New Zealand Writing - by A. Mulgan

Landfall Country 1947-1961 - chosen by C. Brasch

Some Chinese Voices Over the Last Century - translated by

R. Alley

Suggestions for Teaching English - in the Primary School 3 NEW ZEALAND Dept of

Education

Verse for You - a record anthology

1963 Poetry

Anthology of Commonwealth Verse - selected by M.J. O'Donnell

A Bibliography of Poetry Printed at the Caxton Club Press and Caxton Press -

Christchurch compiled by M. Walton

A Collection of Prose and Poetry - from Students of the Elam School of Fine Art

Fifth Green Bottle - Timaru Boys' High School

Golden Thoughts - from Aunt Daisy's scrapbook - mainly verse

Index of Australian New Zealand Poetry - compiled by

E.I. Cuthbert

New Zealand: Gift of the Sea - text by Maurice Shadbolt

New Zealand Through Young Eyes - edited by T.J. Power

Poems of 1963 - Stockwell, Devon

Travelling Abroad - edited by A. Elliott-Cannon

1964 Poetry

A Book of New Zealand - edited by J.C. Reid

Discovering New Zealand Writing - an anthology for third, fourth and fifth forms

compiled by P.R. Smart

Exploring New Zealand Writing - an anthology for senior students compiled by P.R.

Smart

Fine Arts Group + 1 - written and visual works compiled by

I.D. Munro, Auckland Teachers Training College

The Poetry Lesson - by J.G. Brown

The Flame Burns On - Karori West Normal School

Lines of Life: Book 1 - a poetry anthology for junior forms edited by P.W. Murdoch (Book

2 1965, Book 3 1968)

Poetry in Australia - Volume 1 chosen by I. Moore

Volume 2 by D. Stewart

Verse for You - Book One a collection of verse for junior forms compiled by J.G. Brown

Verse for You - a record anthology selected by W.B. Harris

Verse for You - edited by J.G. Brown

New Zealand Poetry Yearbook 1-11 - (1951-1964) edited by 
Louis Johnson

1965 Poetry

The Ballad of Adrian Total - by P. Reesby and B. Bell

The Froth-Blowers' Manual - compiled by P. Lawlor

New Zealand Folksongs - selected by N.J. Colquhoun

Pleasure in English - edited by J.R.C. Yglesias and M.C. McLaren

Recent Poetry in New Zealand - edited by C. Doyle

The Story of Dido and other translations - by G. Lincoln-Lee

A Way of Saying - by K. Smithyman

Young Commonwealth Poets '65 - New Zealand pp110-120 ed. by K. Ireland

1966 Poetry

The Commonwealth in Print 1966 - by W.H. New reprinted from 'CANADIAN

LITERATURE Autumn 1966' pages 53-58 Turnbull Library reference $8201966 \mathrm{p}$

London Magazine Poems 1961-66 - edited by H. Williams

Let's Learn English 3 - by P.R. Smart

Modern Poems for the Commonwealth - edited by M. Wollman and J. Spencer

Poetry - reading and understanding: an anthology edited by

K.G.W. Cross

Poetry Australia - number nine: New Zealand issue edited by

MacD.P. Jackson

Poetry Broadsheet 1 - (1966) Victoria University of Wellington Literary Society

Small Prophets and Quick Returns - by C. Doyle

The Wind and the Rain - a book of poems for school children

New Zealand Dept of Education School Publications Branch

1967 Poetry

Aspects of Poetry in New Zealand - by J.K. Baxter

Birds of Paradise - Bird-life in Australia and New Zealand edited by J. Pollard

Collection of Wairarapa Poets - R.P. Stevens Bookshop

Commonwealth Poets of Today - edited by H. Sergeant (New Zealand pages 191-208)

Ellen's Gift and other Stories, Poems and Plays - New Zealand Dept of Education

School Publications Branch School Journal Pt 3 no 31967

Let's Learn English 4 - by P.R. Smart

Lines of Life Book 3 - edited by P.W. Murdoch

The Man on the Horse - by J.K. Baxter

New Choice - poems for boys and girls edited by J. and D. Colmar (1967/8)

The New Poetic - by C.K. Stead

Old Man's Island and $\mathbf{1 4}$ other stories - originally published as New Zealand Dept of

Education School Publications Branch School Journal Pt 4 No 31967

Poetry Broadsheet 2 - 1967 Wai-Te-Ata Press

School Certificate Literature - by P.R. Smart

Shanties by the Way - edited by R. Bailey and H.O. Roth

Strawberry Fields - edited by R. Glover

Twelve Women Poets of New Zealand - by P.A. French

1968 Poetry

Australian Writing Today - edited by C. Higham

Exploring Poetry - by J. Peek

Modern Verse for You - poetry of today for sixth forms edited by

P. Day and J.G. Brown

New Poems 1967 - a PEN anthology edited by Pinter, Fuller, Redgrove

New Voices of the Commonwealth - edited by H. Sergeant

A New Zealand Approach to English - edited by I.A. and M.C. McLaren 
New Zealand Literature in the University Libraries of the United Kingdom - a pilot survey by P. Alcock (unpublished, held at Turnbull Library)

New Zealand from the Air - text by J. Pascoe

On Native Grounds - Australian writing from Meanjin Quarterly selected by C B

Christesen

Poems from Hospital - compiled by J. and H. Sergeant

Poet - an international quarterly vol 9 no 51967 New Zealand number quest editor Helen Shaw

Poetry in New Zealand 1850-1930 - a thesis submitted for PhD at the University of

Auckland by T. Kingsbury

Voices - the second book edited by G. Summerfield

Voices - the third book an anthology of poetry and pictures Penguin

1969 Poetry

A Book of Goblins - edited by A. Garner

Generations - Poetry from Chaucer to the present day edited by

J. McAuley

Glistening Waters - a collection of literary and artistic works by young people of the

Wairarapa

Love Juice no 1 - compiled by M. Young and M. Duckett the Poets' Cooperative

Auckland

Mainly Modern - an anthology of verse selected by J. and D. Colmar

Poetry Dunedin 1969 - edited by H.W. Smith, Dunedin Poetry Workshop

Rising Early - story poems and ballads of the twentieth century edited by C. Causley

School Certificate Language - by P.R. Goddard (revised 1974)

Themes - conflict edited by R. Jones

Themes - generations edited by R. Jones

Themes - imagination edited by R. Jones

1970 Poetry

An Anthology of Twentieth Century New Zealand Verse - compiled by Vincent

O'Sullivan

Australia and New Zealand - [Literature of] by G.A. Wilkes and

J.C. Reid. Turnbull library reference 820.9 WIL 1970

Castings - by five girls of Nelson College for Girls

Contemporary Māori Writing - edited by M. Orbell

Contemporary Poets of the English Language - edited by

R. Murphy

Facing Exercises - poems by D. Melser and J. Wong Sing Tai

Flux - anthology (early 1970s)

God Alive - magazine of Saint John's Theological College

LLAREGGYB - edited by B. Hales

A Manifold Voice - studies in Commonwealth Literature by

W. Walsh (1916-)

New Zealand National Bibliography to the Year 1960 -

five volumes

New Zealand Poetry - an introduction through the discussion of selected poems by F.

McKay

Pacific and Other Verse - for junior forms edited by J.G. Brown

A Pleasure of Friends - edited by P. Hooper

Poetry Broadsheet - six issues Handcraft Press

Poetry is What - a book of poems edited by L.J.M. Hannan

and B.A. Breen

Proceedings of a Weekend School - held in Dunedin 3-4 October 1970 New Zealand Library Association Otago Branch

Selected Poems for English IB - University of Canterbury English Dept (ca 1970) 
Transition - an Australian Society of Authors Anthology selected by N. Keesing. Turnbull Library reference $820.8 \mathrm{p}$

World of Challenge Vol 1 edited by M.L. Sweeny (two other volumes later)

\section{SUPPLEMENT to 1970}

\section{CONTEMPORARY POETS OF THE ENGLISH LANGUAGE}

bibliography edited by Rosalie Murphy

1243 pages National Library reference 821.09 MUR $p$

Two editions

St James Press Chicago 1970

St Martin's Press New York 1971

Copies of the Chicago edition are held in

The Central Otago District Library (ALP)

Christchurch City Libraries (CP)

Massey University Library (PU)

University of Waikato Library $(\mathrm{HU})$

Victoria University of Wellington Library (WU)

Copies of the New York edition are held in

Invercargill City Libraries (IP)

North Shore Libraries (NSP)

The Bill Robertson Library (Otago) (DTY)

University of Auckland, General Library (AU)

There is a copy in the Turnbull Library.

This is a large scale bibliography for which James Bertram was an adviser, also J C Reid, Joan Stevens, C K Stead, Kendrick Smithyman. There is no list of which poets are covered, but it includes New Zealanders. However, Dr. Wright has gone through the book and probably found all the New Zealanders (even at a stretch), of which this is a list with the commentators where named.

Authors are in alphabetical order in the book.

Fleur Adcock

Rewi Alley

Bruce Beaver

James Bertram

Peter Bland

Charles Brasch

Alistair Campbell

Gordon Challis

Merval Connelly

Allen Curnow

Ruth Dallas

Basil Dowling

Charles Doyle

Eileen Duggan

Ruth Gilbert (under Mackay)

Denis Glover

William Hart-Smith

Louis Johnson

M K Joseph

Owen Leeming

R A K Mason

W H Oliver

Vincent O'Sullivan

Gloria Rawlinson

J C Reid 


\author{
Elizabeth Riddell \\ Keith Sinclair \\ Stuart Slater \\ Kendrick Smithyman \\ Mary Stanley (under Smithyman, Mary Isabel) \\ Charles Spear \\ Jon Stallworthy \\ C K Stead \\ Joan Stevens \\ Douglas Stewart \\ Hone Tuwhare \\ Anton Vogt \\ J E Weir \\ Patrick S Wilson \\ Hubert Witheford
}

${ }^{1}$ This checklist is designed to show what is available by and about New Zealand poets during the period 1945 to 1970 . As with this thesis as a whole the aim is to bring to the fore work of women writers who may have been neglected or lost. In this checklist the aim is to draw attention to publications in which New Zealand poetry appears or is discussed, particularly overseas anthologies, but which are rarely if ever noted in critical and historical accounts. A significant number of these publications feature or deal with poets who are women or are written or edited by women.

${ }^{2}$ Compiled by: Dr F W Nielsen Wright: BA, MA (Hons, $1^{\text {st }}$ class), PhD (VUW).At some time Dr Wright may publish his not inconsiderable annotation of these items, but to be effective those annotations need to address an identified need, whatever that may be (for instance New Zealanders appearing in Australian, or Commonwealth, or international anthologies). But the one item he felt he could not fail to annotate here is given as an appendix to 1970. 


\section{Appendix 10}

\section{New Zealand Fiction Checklist ${ }^{1}$}

New Zealand Fiction 1945 to 1970

1945 Fiction ( 5 by men)

Davin, D M. Cliffs of Fall

Lawson, Will. The Lady of the Heather

Sargent, Winston. The Palms Bend Down

Sargeson, Frank. When the Wind Blows

Uren, Martyn. They will Rise: an epic of Greece under the Axis

1946 Fiction ( 4 by men, 2 by women)

Bolitho, Hector. No Humour in My Love, and two other stories

Lawson, Will. Forbidden Gold

Mountain, Julian. The Prisoners; a romance

Peacocke, Isabel. London Called Them

Scanlan, Nelle. Kit Carmichael

West-Watson, Keith. Achmet and the Colonel

1947 Fiction ( 3 by men, 3 by women)

Baume, Eric. Mercia Wade

Davin, Dan. For the Rest of our Lives

Grieve, Hamilton. Something in the Country Air

Marsh, Ngaio. Final Curtain

Rees, Rosemary. Penelope Waits, a novel

Walsh, Mrs Hazel. The Fourth Point of the Star

1948 Fiction ( 7 by men, 5 by women)

Ballantyne, David Watt. The Cunninghams

Baume, Eric. Devil Lord's daughter

Carman, Dulce. Neath the Maori Moon: a New Zealand romance (Māori)

Courage, James. The Fifth Child

Eden, Dorothy. The Schoolmaster's Daughters

Finlayson, Roderick David. Tidal Creek

MackeNew Zealandie, Andrew Carr. The House at the Estuary

Mergendahl, Charles Henry. The Spring of Love

Mountain, Julian. Love is Vanity; a novel

O'Sullivan, Katherine. (Morgan). The Loves of Dretta Gray

Park, Rosina Ruth Lucia. (Mrs D'Arcy Niland, wrote as Ruth Park) Harp in the South

Scanlan, Nellie. The Rusty Road

1949 Fiction ( 4 by men, 5 by women)

Davin, Dan. Roads from Home

De Mauny. Erik Cecil Leon, The Huntsman in his Career

Guthrie, John. Journey into Twilight 
McDonald, Georgina Bruce. (Blaikie) Grand Hills for Sheep

Marsh, Ngaio. Swing Brother, Swing

Park, Ruth. Poor Man's Orange

Quentin, Dorothy. The Golden Hibiscus

Sargeson, Frank. I Saw in My Dream (Māori)

Texidor, Greville. (Mrs Droescher) These Dark Glasses

1950 Fiction ( 4 by men, 8 by women)

Carman, Dulce. (Edith Marie Dulce Drummond) The Riddle of the Ranges: a New

Zealand romance

Cherrill, Amy Lilian. Story of a New Zealand Sheep Farm

Courage, James. Desire Without Content

Grieve, Mrs Hamilton. It's Nothing Serious: a novel

Guthrie, John. Is This What I Wanted?

Guthrie, John. Merry-go-round

Peacocke, Isabel. Concerning the Marlows

Quentin, Dorothy. (pseudonym David King) The Mountains are Still Green

Quentin, Dorothy. Reach Me a Star

Scanlan, Nelle. Confidence Corner

Whitworth, Jess. Otago Interval

Wilson, Guthrie Edward Melville. Brave Company

1951 Fiction ( 2 by men, 2 by women)

Anthony, Frank and Francis Jackson. (illustrated by Neville Lodge) Me and Gus

Lawson, Will. Gold in Their Hearts: a novel of New Zealand's early days

Marsh, Ngaio. Opening Night (also published in the US in 1951 under the title Night at the Vulcan)

Park, Ruth. The witch's Thorn (Māori)

1952 Fiction ( 8 by men, 2 by women)

Anthony, Frank and Francis Jackson. (illustrated by Neville Lodge) More Me and Gus

Courage, James. Fires in the Distance

Eden, Dorothy. Cat's Prey

Gilbert, Gavin Robert. Glass Sharp and Poisonous

Guthrie, John. Paradise Bay

Guthrie, John. The Seekers (Māori)

Rhodes, Denys. Fly Away Peter

Sargeson, Frank. I for One

Scanlan, Nelle. The Young Summer

Wilson, Guthrie, Julien Ware

1953 Fiction ( 3 by men, 7 by women)

Baume, Eric. The Mortal Sin of Father Grossard

Cathie, Diarmid. (pseudonym) She's Right

Eden, Dorothy. Lamb to the Slaughter

Finlayson, Roderick. The Schooner Came to Atia

Hill, Jean. Wind May Blow

Marsh, Ngaio. Spinsters in Jeopardy

Mason, Henrietta Rex. White Orchid

Park, Ruth. A Power of Roses

Quentin, Dorothy. The Blue Gum Tree 
1954 Fiction ( 4 by men, 5 by women)

Campbell, Margo. The Dark Water

Carman, Dulce. The Tapu Tree: a romance of Maoriland (Māori)

Courage, James. The Young have Secrets

Eden, Dorothy. Bride by Candlelight

Garland, Stuart. The Importance of Being Honest

Gillies, John Russell. Voyagers in Aspic

McDonald, Georgina. Stinson's Bush: a novel

Scott, Mary. Yours to Oblige

Wilson, Guthrie. The Feared and the Fearless

1955 Fiction ( 6 by men, 9 by women)

Anthony, Frank and Francis Jackson. (illustrated by Neville Lodge) Me and Gus Again Cody, Joseph Frederick. The Red Kaka (Māori)

Jeffery, Margaret. The Forsaken Orchard (based on author's radio serial)

Kenyon, Frank Wilson. Emma

Mackersey, lan. Crusader Fox King

Mann, Catherine. The Silent Mountain (Māori)

Marsh, Ngaio. Scales of Justice

Park, Ruth. (illustrated by Phil Taylor) Pink Flannel

Phipps, Grace Mary. Marriage with Eve

Quentin, Dorothy. The Generous Heart

Sandford, Kenneth Leslie. Dead Reckoning

Wills, Cecil Melville. Death in the Dark

Wilson, Helen. Land of My Children

Winder, Mavis Areta. (Wright) Shadowed Journey (Māori)

Wingate, March. Red East

1956 Fiction ( 7 by men, 12 by women)

Courage, James. The Call Home

Crisp, Frank. Maori Jack's Monster (Māori)

Davin, Dan. The Sullen Bell

Dorien, Ray. Flower of Delight

Hill, Jean O'Hagan. (Morton) Sun at Noon

Jones, Arthur Edwin. You Know the Way It Is: a Felix Holiday story

McCarthy, Darry. Fly Away Dove!

McClymont, Margot Kate. The Dark Valley

Mann, Catherine. One Who Bears Your Name (Māori)

Marsh, Ngaio. Death of a Fool (published in London as Off with his Head)

Phipps, Grace. The Women of the Family

Preston, Florence Margaret. A Gallows Tree

Rees, Rosemary. Better to Trust

Reyburn, Wallace. Follow a Shadow

Scott, Mary. Families are Fun

Thwaites, Frederick Joseph. That was the Hour (Māori)

Wilson, Guthrie. Sweet White Wine

Winder, Mavis. The Stubble Field

Yager, Marie J. Complex Counterpart 


\section{Fiction ( 5 by men, 8 by women)}

Burfield, Eva. (pseudonym for Mrs Frances Eva Ebbett) Yellow Kowhai Cross, lan. The God Boy

Ellis, Michael. (pseudonym for Stephen Peter Llewellyn) The Score at Tea-time

Fenton, Elizabeth. Beware My Heart: a New Zealand romance

Frame, Janet Paterson. Owls Do Cry

Joseph, George Israel. Lie Fallow My Acre (Māori)

Lord, Albert Fawcett. Kauri Hill

Park, Ruth. One-a-pecker, Two-a-pecker (published in 1962 by Pan as The Frost and the Fire)

Preston, Florence. Harvest of Daring

Reyburn, Wallace. Port of Call

Salter, Elizabeth. Death in a Mist

Scott, Mary. The Unwritten Book

Wilson, Guthrie. Strip Jack Naked

\section{Fiction ( 7 by men, 8 by women)}

Ashton-Warner, Sylvia Constance. (Mrs Henderson) Spinster (filmed in the US in 1961 as Two loves) (Māori)

Boswell, John. The Blue Pheasant

Burfield, Eva. (pseudonym) A Chair to Sit On

Cameron, Ian. The Midnight Sea

France, Helena Ruth. The Race

Gurr, Thomas Stuart (and H W Cox). Obsession

Joseph, Michael Kennedy. I'll Soldier No More

McClymont, Margot. Green Harmony

Manning, Arthur. We Never Die in Winter

Marsh, Ngaio. Singing in the Shrouds

Messenger, Elizabeth. ie Betty Margery (Esson) Murder Stalks the Bay

Noonan, Michael. The Patchwork Hero

Preston, Florence. Great Refusals

Rees, Rosemary. Love is a Lonely Land

Ruhen, Olaf. Naked Under Capricorn

Sutton, Phyllis. Marana

1959 Fiction ( 9 by men, 9 by women)

Brathwaite, Errol Freeman. Fear in the Night

Courage, James. A Way of Love

Davin, Dan. No Remittance

Duckworth, Marilyn Rose. (Adcock) A Gap in the Spectrum

Fowler, Percy Lee. Brown Conflict: a tale of white man and Maori: 1861-2 (Māori)

Lindsay, Kathleen. Beware of the Dawn

Marsh, Ngaio. False Scent

Messenger, Elizabeth. Material Witness

Preston, Florence. The Gay Pretensions

Quentin, Dorothy. The Unchanging Love

St Bruno, Albert Francis. (wrote as Frank Bruno) The Hellbuster

Scott, Mary. The White Elephant

Slatter, Gordon Cyril. A Gun in My Hand

Stringfellow, Mrs Olga. The Fresh and the Salt

Summers, Essie. The Lark in the Meadow (Number 184 in the Woman's Weekly Library under the title The long journey)

Tindale, Norman Barnett and Harold A Lindsay. (illustrated by

Douglas F Maxted) Rangatira, the High-born: a Polynesian saga (Māori) 
1960 Fiction (13 by men, 12 by women)

Ashton-Warner, Sylvia. Incense to ldols

Carell, Victor. Naked we are Born (Māori)

Cross, lan. The Backward Sex

Crump, Barry John. (illustrated by Dennis Turner) A Good Keen Man

Davis, Lydia, and Tom Davis. Makutu (Māori)

Deverell, Dijon. (Evangeline) Recognition

Duckworth, Marilyn. The Match-box House

Eden, Dorothy. Sleep in the Woods (Māori)

Hilliard, Noel Harvey. Maori girl (Māori)

KeiNew Zealandly, Mrs Frances. Tangahano

Llewellyn, Stephen. (pseudonym Michael Ellis) The Angel in the Coffin

Manning, Arthur. The Short Madness

Mason, Henrietta Rex. Fool's Gold

Messenger, Elizabeth. Light on Murder

Muir, Mcgregor Robin. Word for Word

Preston, Ivy Alice. (Kinross) Where Ratas Twine

Quentin, Dorothy. Rainbow Valley

Reyburn, Wallace. Three Women

Rhodes, Denys. The Syndicate

Rogers, Ray Mount. The Long White Cloud

Ruhen, Olaf. White Man's Shoes

St Bruno, Francis. Black Moon at Ngutu (Māori)

Scott, Mary and Joyce West. Fatal Lady

Scott, Mary. No Sad Songs

Wilson, Guthrie. The Incorruptibles

\section{Fiction ( 9 by men, 4 by women)}

Booth, Patrick. Long Night Among the Stars

Brathwaite, Errol. An Affair of Men

Brent, Marama. Bird in the Wilderness

Courage, James. The Visit to Penmorten

Cross, lan. After ANew Zealandac Day

Crump, Barry John. Hang on a Minute Mate

Frame, Janet. Faces in the Water

France, Mrs Helena Ruth. Ice Cold Water

Garford, James. Seventeen Come Sunday

Griffin, Andrew Dow. Sailin' down the Clyde

Kenyon, Frank. Mrs Kelly or Restoration Divertimento

MacKeNew Zealandie, Andrew. Voice from the Cell

Park, Ruth. The Good-looking Woman

\section{Fiction ( 9 by men, 16 by women)}

Carman, Dulce. The False Dawn (a romance of Maoriland) (Māori)

Carman, Dulce. The Miracle of Tane (Māori)

Crump, Barry. One of Us

Davis, Michael Henry Lester. (illustrated by Keith S Clark) Mutton on the Menu (Māori)

Eden, Dorothy. Whistle for the Crows

Frame, Janet. The Edge of the Alphabet

Gee, Maurice Gough. The Big Season

Grayland, Valerie Merle. (Spanner) The Dead Men of Eden 
Joseph, George Israel. When the Rainbow is Pale (Māori)

Joseph, M K. A Pound of Saffron

Marsh, Ngaio. Hand in Glove

Messenger, Elizabeth. Golden Dawns the Sun

Phipps, Grace. The Young Wife

Preston, Ivy. Magic in Maoriland (Māori)

Rees, Rosemary. The Proud Diana (Māori)

Reyburn, Wallis. Good and Evil

St Bruno, Francis. Fury at Finnegan's Folly

Sanderson, Nora. (Brocas) Hospital in New Zealand

Scott, Mary and Joyce West. Such Nice People

Smith, Michael L. No Easy Answer

Tullett, James Stuart. Tar White

Wallis, Redmond Frankton. Point of Origin

Winder, Mavis. Memory's Yoke

Worboys, Anne (Eyre). Call for a Stranger

Worboys, Anne (Eyre). Three Strings to a Fortune

1963 Fiction ( 23 by men, 28 by women)

Addison, Mrs Doris Maureen. (Bentley) Valley in the Clouds

Adsett, Delphin Rose. (wrote as Dell Adsett) A Magpie Sings

Anthony, Frank. (and Francis Jackson: illustrated by Neville Lodge) The Complete Me and Gus

Archibald, Menie. The Long White Cloud

Audley, Ernest Henry. No Boots for Mr Moehau (Māori)

Bacon, Ronald Leonard. (illustrated by David More) In the Sticks

Ballantyne, David. The Last Pioneer

Bennett, Margo. That Summer's Earthquake

Brown, J Edward (illustrated by Keith S Clark). Luck of the Islands (Māori)

Carman, Dulce. The Maori Gateway: a romance of Maoriland (Māori)

Casey, R. (pseudonym for Kenneth Robert Christian) As short a spring

Crump, Barry. (illustrated by Dennis Turner) There and back

Dingwell, Joyce. The New Zealander

Duckworth, Marilyn. A Barbarous Tongue

Eden, Dorothy. The Bird in the Chimney

Frame, Janet. Scented Gardens for the Blind

Grayland, Valerie. Night of the Reaper (Māori)

Harvey, Norman Bruce. Any Old Dollars Mister?

Hill, Jean. A Family Affair

Hughes, Ivy. The Singing Water (Mãori)

Hurne, Ralph. Larks in Cages

Joseph, George. The Insider

Joyce, Thomas Heath. Whose Candle is the Sun

Kennedy, Marion. The Wrong Side of the Door

MacKay, Mrs Margaret Elizabeth. Amanda

Maddock, Shirley Francis Whitley. With Gently Smiling Jaws

Manning, Arthur. Tainted money

Mason, Henrietta. Our Hills Cry Woe!

Messenger, Elizabeth. A Heap of Trouble

Morrieson, James Ronald Hugh. The Scarecrow

Noonan, Michael. The December Boys

Pearson, Bill. (William Harrison Pearson) Coal Flat

Peters, Charles. (pseudonym Charles Francis) The Big One

Phipps, Grace. A Nurse like Kate

Preston, Ivy. Island of Enchantment

Preston, Ivy. Tamarask in Bloom

Quentin, Dorothy. The Dark Castle 
St. Bruno, Francis. Cockeye Kerrigan

St. Bruno, Francis. Yellow Jack's island

Sanderson, Nora. The Ordeal of Nurse Thompson

Sanderson, Nora. The Two Faces of Nurse Roberts

Scott, Mary. The Long Honeymoon

Scott, Mary and Joyce West. The Mangrove Murder

Stephenson, Ralph. Body in My Arms

Summers, Essie. South to Forget

Summers, Essie. Where No Roads Go

Thomas, William Herne. The Man Who Gave

Tullett, James. Yellow Streak

Wilson, Guthrie. The Return of the Snow-white Puritan

Wilson, Phillip John. Beneath the Thunder (Māori)

Winder, Mavis. How Great a Fire

1964 Fiction ( 21 by men, 32 by women)

Addison, Doris. Mara (Māori)

Ashton-Warner. Sylvia, Bell Call

Bacon, Ronald. (illustrated by David More) Along the road

Benjamin, Philip. Quick Before it Melts

Booth, Pat. Footsteps in the Sea

Brathwaite, Errol. The Flying Fish (Māori)

Brathwaite, Errol. Long Way Home

Burfield, Eva. The Long Winter

Burgess, Michael. Mister

Carman, Dulce. The Pool of Wisdom (Māori)

Carman, Dulce. Tomorrow's Sun

Clarke, Mrs Neva Yvonne. Behind Closed Doors

Coop, Harold Valentine. (wrote as Harold Valentine) House Surgeon

Cooper, Mrs Evelyn Barbara. Target for Malice

Crump, Barry. (illustrated by Will Mahoney) Gulf

Crump, Walter William. McDunnit Dunnit

Davis, Michael Henry Lester. Watersiders

Eden, Dorothy. Bella

Fenwick, Margaret. The Tempered Wind

Geddes, Adrienne Marie. (Kelliher) The Rim of Eternity

Gee, Wallace. Moral Issues Here and Abroad

Grayland, Valerie. The Grave-digger's Apprentice (Māori)

Henshaw, William Keith. Kath

House, L C. (Lesley, pseudonym for Elsie Macleod-Smith) The Faces of Love

Howe, A. Stamper Battery

Hughes, Ivy. Halo Round the Moon

Jay, Simon. (pseudonym for Dr Colin James Alexander) Death of a Skin Diver

Jeffery, Gretchen Constance Emilie. (Weyergang) Mairangi

Johnson, Marguerite Maude. (pseudonym for Rewa Glenn, woodcuts by Elizabeth

Johnston, pseudonym) A Holiday Idyll

Lee, John. Shiner Slattery

Marsh, Ngaio. Dead Water

Messenger, Elizabeth. Growing Evil

Messenger, Elizabeth. You Won't Need a Coat

Morrieson, Ronald. Came a Hot Friday

Owen, Doreen May. A Stranger Stands

Peters, Charles. (wrote as Charles Francis) Ask a river

Peters, Charles. Johnny Rapana (Māori)

Preston, Ivy. Hearts do not Break

Robertson, Mrs Rita Clarice. I Dare not Mourn

Sanderson, Nora. A Partner for Doctor Philip 
Sanderson, Nora. Shadows in the Ward

Sanderson, Nora. The Taming of Nurse Conway

Sava, George. (pseudonym) A Surgeon in New Zealand

Scott, Mary. A Change from Mutton

Scott, Mary and Joyce West. No Red Herrings

Summers, Essie. Bride in Flight

Summers, Essie. The Smoke and the Fire

Summers, Essie. The Time and the Place

Summers, Essie. Where No Roads Go

Tullett, James. Red Abbott

Wilson, Phillip. Pacific Flight

Winder, Mavis. (wrote as Mavis Areta) Love Keeps No Score

Worboys, Anne. Visit to Rata Creek

1965 Fiction (17 by men, 24 by women)

Addison, Doris. Bird of Time

Addison, Doris. A Greenstone of Two Colours (Māori)

Audley, Ernest. A New Gate for Mattie Dulivich

Baldwin, Beatrice Lilian. The Red Dust

Bevan, Gloria. (pseudonym for Fiona Murray) Invitation to Danger

Billing, Graham John. Forbush and the Penguins

Booth, Patrick. Dear Chevvy

Brathwaite, Errol. The Needle's Eye

Carman, Dulce. The Youngest One

Coumbe, Eric Edwin. The Cold Moon of Spring

Crump, Barry. (illustrated by Roger Hart) Scrapwaggon

Dryland, Gordon Boyce. An Absence of Angels

Eden, Dorothy. The Marriage Chest

Frame, Janet. The Adaptable Man

Gee, Maurice. A Special Flower

Grayland, Valerie. Jest of Darkness (Māori)

Hilliard, Noel. Power of Joy (Māori)

Holden, Anne Jacqueline. (Dare) Rata: a novel about childhood (Māori)

Holt, Sheila Betty. (Archibald, wrote as Betty Holt and Elizabeth Fagan) Jennifer Grant,

New Zealand Nurse

Koch, F. A Casual Company

McKenny, Kenneth. The Hide-away Man

Messenger, Elizabeth. The Tail of the Dozing Cat

Messenger, Elizabeth. Uncertain Quest

Olivier. Mrs Sally T. Petticoat Farm

Owen, Doreen. Not so the Land

Preston, Ivy. The Blue Remembered Hills

Robertson, Rita. The Crooked and the Narrow

Ruhen, Olaf. The Broken Wing

S.S. His Own Enemy: the story of an alcoholic

Sanderson, Nora. The Case for Nurse Sheridan

Sargeson, Frank. Memoirs of a Peon

Scott, Mary. Freddie

Scott, Mary and Joyce West. Who Put it There?

Shadbolt, Maurice Francis Richard. Among the Cinders

Tarrant, Noeline. Dead on Noon

Tullett, James. White Pine

Watson, Jean. Stand in the Rain

Wilson, Phillip. The Outcasts

Winder, Mavis. River in the Valley

Winder, Mavis. Scent of the Woods 
Worboys, Anne. The Valley of Yesterday

1966 Fiction (14 by men, 10 by women)

Ashton-Warner, Sylvia. Greenstone (Māori)

Ballantyne, David. A Friend of the Family

Bates, Peter. The Red Mountain

Bennett, Francis Oswald. The Tenth Home

Booth, Patrick. Sprint from the Bell

Eden, Dorothy. Never Call it Loving

Ewen, J M. Far from the Sun

Hammond, Theodore Peter. (illustrated by Jack Morgan) This Man's Father had my

Father's Farm

Houghton, Philip. The Shadow of the Land Hughes, Ivy. A Falcon Rising (Māori)

Hunter, Harriet. Inclination to Murder

McClenaghan, John Nathaniel. Moving Target

Marsh, Ngaio. Killer Dolphin

Mason, Henrietta. High Acres

Neate, Frank Anthony. The Hour-glass Girl

ST. Bruno, Francis. Riggermortis

Scott, Mary. What Does it Matter?

Scott, Nicholas D. The Lancet and the Land

Staples, Marjory Charlotte. (Jefcoate), (wrote as Rosaline Redwood) Forgotten Heritage

Stephenson, Ralph. Down Among the Dead Men

Thompson, Nola Dilyse (Payne). The Share Milkers: a novel of the Waikato

Tullett, James. Hunting Black

Worboys, Anne. Return to Bellbird Country

Wylie, Cicely. The Language of Love

1967 Fiction ( 13 by men, 12 by women)

Addison, Doris. Jane

Addison, Doris. Morning Tide (Māori)

Andrews, Philip. Terese

Brathwaite, Errol. The Evil Day (Māori)

Burke, David. Monday at McMurdo

Carman, Dulce. The Necklace of El-Hoya

Cowley, Cassia Joy. (Summers), (filmed as 'The night digger') Nest in a Falling Tree

Crump, Barry. The Odd Spot of Bother

Eden, Dorothy. Winterwood

Frame, Janet. A State of Siege

Gilbert, Manu. Lineman's ticket

Grover, Raymond Frank. Another Man's Role

Harvey, Norman Bruce. One Magpie for Sorrow

Holden, Anne. The Empty Hills

Joseph, Michael (MK). The Hole in the Zero

Journet, Terence Harry. The Death Wishers

Lambe, Zoe Violetta. (Lane) Murder by Court Martial (Māori)

McLeod, Mrs Catherine Styles. Dorinda

Owen, Maurice. White Mantle

Pothan, Kep. A time to Die

Sargeson, Frank. The Hangover

Scott, Mary. Yes, Darling

Shadbolt, Maurice. The Presence of Music; three novellas

Staples, Marjory. Isle of the Golden Pearls (Māori)

Winder, Mavis. The Glitter and the Gold 
Ballantyne, David. Sydney Bridge Upside Down

Bates, Peter. Man out of Mind

Bennett, Margot. The Furious Masters

Brodie, Gordon. The lady had a Tiger

Brodie, Gordon. The Poison of Poppies

Frame, Janet. The Rainbirds (published in US as 'Yellow flowers in the antipodean room') Holden, Anne. Death After School

Hughes, Ivy. The Barrier

Jay, Simon. Sleepers Can Kill

Johnson, Marguerite Maud. (pseudonym Rewa Glenn, woodcuts by Elizabeth Johnston)

The turn of the tide

Journet, Terence. The God Killers

McGregor, Miriam Florence. The Glowing Dark

Marsh, Ngaio. Clutch of Constables

Moore, Mary. Where Kowhai Blooms

Mutch, Karin. Wildcat

Preston, Ivy. Red Roses for a Nurse

Sanderson, Nora. No Bells were Ringing

Sanderson, Nora. No Welcome for Nurse Jane

Scott, Mary. Turkey at Twelve

Slatter, Gordon. The Pagan Game

Staples, Marjory. Stranger from Shanghai

Summers, Essie. Rosalind Comes Home

Winder, Mavis. The Fanned Flame

1969 Fiction (11 by men, 23 by women)

Andrews, Isobel Smith (Young). Return to Marara

Bevan, Gloria. The Distant Trap

Billing, Graham. The Alpha Trip

Bliss, Alice. Spring in the Bishop's Palace: a novella

Burfield, Eva. Give Them Swing Bands (Māori)

Dorman, Thomas Edwin. The Days After

Duckworth, Marilyn. Over the Fence is Out

Graham, Timothy M.A. The Paper Man

Hilliard, Noel. A Night at Green River (Māori)

Jackson, Laurence. Mana (Māori)

KeiNew Zealandley, Frances. A Time to Prey

McCLenaghan, Jack. The Ice Admiral

McGregor, Miriam. The Drifting Mist

McGregor, Miriam. The Whispering Echo

Mason, Francis van Wyck. Harpoon in Eden

Moore, Mary. Rata Flowers are Red

Mutch, Karin. Cindy Tread Lightly

Noonan, Michael. The Pink Beach

Phipps, Grace. No Wife for a Parson

Preston, Ivy. April in Westland

Preston, Ivy. Ticket of Destiny

Prior, Anne. Mirror Image

Quentin, Dorothy. Goldenhaze

Rooke, Daphne Marie. Boy on the Mountain

Ruhen, Olaf. Scan the Dark Coast

Sanderson, Nora. Stranger to the Truth

Sargeson, Frank. Joy of the Worm

Scott, Mary. Strictly Speaking

Shadbolt, Maurice. This Summer's Dolphin 
Sneller, Jean. Heart of Gold

Summers, Essie. The Kindled Fire

Summers, Essie. Revolt - and Virginia

Swift, Rachelle. (pseudonym for Jean Lumsden) The House at Green Bay

Winder, Mavis. The lamp in the window

\section{Fiction ( 11 by men, 23 by women)}

Ashton-Warner, Sylvia. Three

Bates, Peter. Old Men are Fools

Bevan, Gloria. Beyond the Ranges

Brent, Marama. Sigh for Selina

Burfield, Eva. To the Garden Alone (Māori)

Cowley, Joy. Man of Straw

Crump, Barry. A Good Keen Girl

Davin, Daniel. Not Here, Not Now

Eden, Dorothy. Waiting for Willa

Frame, Janet. Intensive Care

Gibson, Colin. The Love-keeper

Henaghan, Rosalie. The Sophisticated Urchin

Hughes, Ivy. The House at Stormy Waters (Māori)

Joseph, George. Take Any City

KeiNew Zealandley, Frances. Illusion

John A Lee. Mussolini's Millions

McGregor, Miriam. Hasten to Danger

McKenny, Kenneth. The Orderly

McLeod, Catherine. Fortunately there was a Haystack

McNeish, James Henry Peter. MackeNew Zealandie

Marsh, Ngaio. When in Rome

Michael, Shona. The Season at Sunrise

Mutch, Karin. The Story of Jody

Nethercote, Ron. The Merciless

Preston, Ivy. A Fleeting Breath

Sanderson, Nora. A Place in the Sun

Scott, Mary. Haven't We Met Before?

Summers, Essie. The Bay of the Nightingales

Summers, Essie. Summer in December

Swift, Rachel. A Taunt From the Past

Swift, Rachel. Vicky

Taylor, William. Episode (Māori)

Taylor, William. The Mask of the Clown

Thian, Valeria Joan. O Kiss Me Kate

Tullett, James. Town of Fear

Worboys, Anne. The Little Millstones

\footnotetext{
${ }^{1}$ This checklist is designed to show what is available by and about New Zealand fiction writers, 1945 to 1970. As with this thesis as a whole the aim is to bring to the fore work of women writers who may have been neglected or lost. I have not included the annotations from Burns. New Zealand Novels and Novelists 1861-1979: an annotated bibliography. Compiled by James Burns (published by Heinemann, Auckland, 1981). I have added the number of men versus women for each year and the indented names are those of women writers. I have indicated where there are Mäori themes in brackets next to the book's title. When the writer has a pseudonym this is indicated in brackets next to the author's name.
} 


\title{
Appendix 11
}

\section{Louis Johnson's review of Ruth Gilbert's book The Sunlit Hour}

The Sunlit Hour. Poems by Ruth Gilbert: Allen \& Unwin, 6s, 48pp [reviewed by Louis Johnson] 'The rare distinction of a New Zealand poet finding an English publisher has fallen rather heavily on Wellington's Ruth Gilbert, for it has focused perhaps more attention than is usual upon a collection of work which is neither Miss Gilbert's best, nor of a standard comparable with that from the top-drawer of New Zealand poetry. Nor is the honour of English publication so great when one considers that the firm of Allen and Unwin - leaders in many other fields, and most distinguished in the present company of English publishers - is not notable for the poetry it produces. One rather gathers that the apparent simplicity of the poems in this book appealed to a publisher whose taste in poetry is somewhat old-fashioned.

'Ruth Gilbert has written poems which are of definite quality - most notably the Lazarus sequence in her first book of which it was the title poem. There are flashes of brilliance and vivid imagery in most of her lesser pieces, but these are frustrating rather than satisfying. Why, one asks, with such flashes of power, is this writer able to bring so few notable poems clean out of the tin? Mr. Baxter, in suggesting a confusion of purposes, has no doubt hit upon one side of the story, but at the expense of drawing the red-herring of 'anti-feminism' into the picture. 'It is not, ultimately, a battle of the sexes which is to be engaged here, but a sortee on the field of the purpose of art. And what Miss Gilbert shows annoyingly with a number of other writers of her sex, is a lack of intention or engagement in her work.

'The purpose of a piece of work in their hands is to be merely decorative, whereas the logic and truth of the situation behind the poem demands engagement in the drama of life. Possibly the best contrived poem in the present book is ...
Hoelderlin: ${ }^{2}$
He asked one summer that his song should ripen
And even as fruit mellowed on the boughs
He passed beyond the sunlight and the singing
Into a songless house
Yet, with such certainty the gods assured him
Of harvest in, of honey in the comb
He smiled upon the dark walls of delusion
Content, and called them home

\begin{abstract}
'Yet, one thinks, the poem is, after all, contrived - just that. For the subject in hand, it is just too smooth, too easy, and shows little realisation of the reality that was faced by Hoelderlin in his patch of darkness. It is indeed typical of Miss Gilbert that his suffering should be passive - that he should, after all, be content and call it home.

'It is this assurance of a happy ending that forces upon one the conclusion of Miss Gilbert's shallowness - most evident in her 'tell me a Bible-story' pieces like 'Once in a Market Place. For her day and age Miss Gilbert chooses 'an outworn poetical method' Georgianism - even to the extent of lifting Georgian lines - 'Gently, invisibly, the wind of the spirit blows' - and of repeating the line in yet another poem. In some respects it is the method favoured in many poems by Denis Glover: the movement is often strong, free, persuasive; the climate intentionally pathetic.

'The eventual difference lies in the final intention. Glover brings off a poem by deliberate understatement; Miss Gilbert's failures degenerate into cuteness or into an unnecessary attempt to smooth away the wrinkles from the world's furrowed brow. Of course, Miss Gilbert must be allowed to write as she likes - but one need not like the poems. A greater share of the world's suffering - with less effort to ease it away with comforting thoughts -
\end{abstract}


would lead her in the direction of that dramatic unity that is so lacking at present. Look at what Yeats made of such material' (Johnson, 1957 \#6: 28-30).

\footnotetext{
${ }^{1}$ Poet, James K. Baxter, co-edited Numbers with Louis Johnson and Charles Doyle, and while Johnson does not elaborate on this reference to 'Mr. Baxter' it is easy to surmise that the two of them discussed the entries and submissions and book reviews that were published in their journal, including the one on Ruth Gilbert.
}

${ }^{2}$ Hölderlin was a German poet-thinker, 1770-1843, who wrote, fragmentarily, on poetic theory and philosophical matters. 


\section{Appendix 12}

\section{Willow Macky's letter to the editor of numbers 7 regarding Johnson's review of Ruth Gilbert's book The Sunlit Hour in numbers 6 and Johnson's reply.}

'To criticise the critics is rather a risky business - especially for an as yet unestablished writer - but, for the sake of justice, this I feel I must do. It is with regard to the unfavourable reviews in New Zealand journals (numbers amongst them) of Ruth Gilbert's latest book of verse 'The Sunlit Hour' - in considerable contrast to the commendation it received overseas. The literary ability, integrity or sincerity of the New Zealand critic is not in question, but it is obvious that they are almost completely lacking in understanding with regard to the woman writer - a fault far more evident in New Zealand than overseas.

'It is not long since the emancipation of women in western countries (in the East they are still very much under masculine domination) and women are still being kept back by standards that, for thousands of years, have been set up by men. Most women, if they wish for success, will try to conform, monkey-like, to the masculine pattern; others, by remaining true to their feminine insight, risk opposition and failure in male-dominated fields. The Victorian poet and critic, Coventry Patmore - one of the few men to recognise women's special contribution in the field of literature - wrote: 'the feminine faculties of 'taste,' of emotion that must have music for its rendering, of shy moderation which never says quite so much as it means, of quickness to 'scent the ridiculous from afar, of the dainty conscience which sets 'decorum' far above all other duties and knows that in poetry the manner is much more important than the matter ...

'All these qualities, together with masculine strength and breadth of vision, are evident in the poetry of Ruth Gilbert. Consequently her work cannot be properly appreciated by those critics who still adhere to purely masculine standards of criticism. Miss Gilbert's nobility of thought is dismissed as 'moralising'; her delicate simplicity (as in the haunting 'Once in a Market Place,' in which one can almost hear the cool, wistful notes of the flute) is passed over as 'shallowness'; her fine workmanship is 'contrived'; and her message of comfort - surely woman's contribution to this shaken world - is deprecated as being unrealistic.

'One critic even confessed himself to be 'embarrassed' by Ruth Gilbert's profound and sensitive expression of maternal feeling. One cannot help thinking he would be wise to consult a psychiatrist (presuming he is a man and not still a boy.) Most probably he would prefer the work of an immature or abnormal woman, or of one who does not reveal so completely her femininity.

'Another complaint is that Miss Gilbert's style is out-moded. One could also call it classical. Do 'modern' writers ever consider how they are dating themselves for the next generation? Yet what is called a modern poem is often one only in contrivance: tidy it a little, put back the commas and capitals and, in many cases, what do you have? An oldfashioned poem! However, the Under-milk-wood miasma of modern verse - delightful in Dylan Thomas, but wearying in his copyists - is not favoured by those whose aim is to clarify rather than to confuse. Mention was also made of Miss Gilbert's publishing firm, Allen \& Unwin, with the remark: 'it is not notable for the poetry it produces.' I have just picked off my bookshelf the poems of Alun Lewis, also published by Allen \& Unwin; surely these could not be considered old-fashioned or undistinguished.

'One hesitates to say so, but it would appear that in New Zealand there is an unconscious resentment on the part of most of our men writers of any recognition that our women writers might achieve. This is understandable, as the rewards of literature especially of poetry - in New Zealand are few and far between. But this does not excuse the tendency to 'gang up' on any woman writer who is not a relative, a protégée, dead or otherwise out of circulation.

'This was most obvious (to give one instance) in the exclusion of Gloria Rawlinson, a noted New Zealand poet and P.E.N. award winner (1956), from the 'Oxford Book of New Zealand Verse' - a flagrant omission which drew protests from the Sydney 'Bulletin' and the N.Z. 'Listener.' Also, never, to my knowledge, has a woman poet been 
invited to participate in the Poetry Readings that are held from time to time in Auckland at the University, Public Library and Art Gallery. And I have waited long and in vain for one of New Zealand's most distinguished and publicised poets, who has expressed to me his profound admiration of Ruth Gilbert's work - especially in 'The Sunlit Hour' - to come forward in her defence. Evidently he does not like to go against 'the boys.

'I do not apologise for dragging out again the 'red herring of anti-feminism' - it smells too badly to be ignored. I do not ask for chivalry - which has no place in criticism but I do plead for a more detached standard of judgement, unfettered by personal loyalties or antipathies. For it seems to me that, in New Zealand particularly, women are judged by masculine standards, and then penalised for being women. Anton Vogt frankly admits:

'For though I am a vigorous defender

Of other's efforts, l'll not idly gamble

On any female poet or defend her

And if male poets sometimes the stresses

They're not as prissy as our poetesses

- a view shared, evidently, by his colleagues.

'Writers have depend very much on critics and editors - usually men - for encouragement. The editor's decision is life or death to a manuscript, and the success of a life-work depends on a favourable review. It is a fact that the few women poets of the Victorian era who attained distinction (Elizabeth Browning, Christina Rosetti, Alice Meynell and, more recently, Edith Sitwell) had, all of them a brother or husband prominent in the literary world, without whose encouragement and influence they might never been heard of. One wonders how many aspiring women writers were crushed out of existence during this period by antagonistic males. And although women nowadays have more confidence in themselves they are naturally still profoundly influenced by masculine attitudes.

'I feel also, that if New Zealand men were more confident of themselves and their own abilities, they would be more generous in giving credit to women, encouraging them, even, and taking a pride in their achievements. For a man of real insight, talent or genius does not fear competition from women: for he will know that, just as a woman complements a man in other spheres, so her literary achievements, far from detracting from his, will widen and enhance the intellectual outlook of the nation.' (Macky, 1957 \#: 26-28)

Louis Johnson wrote a rejoinder to the above under the title:

Our Critic Replies:

'Miss Macky would have it that we women-hating editors are being unfair to the sisterhood of the pen. Here is numbers' own record over the past six issues, showing the proportion of work by women: -

No. $1: 2 \frac{1}{2}$ pages out of 32 .

No. 2: $211 \frac{1}{2}$ pages out of 40 .

No. 3: 5 pages out of 36 .

No. $4: 81 \frac{1}{2}$ pages out of 40 .

No. 5: 1 page out of 32 .

No. 6: 13 pages out of 32 .

Now had we cunning editors been intent on giving offence to no-one, we'd surely have eliminated some of the males from No. 5 and begged work from some of the ladies.

'But it happens that numbers isn't edited on that basis. We simply go for the best work we can get for an issue. Since we've been asked to look at the problem in this battleof-the-sexes way, we might generalise that our women contributors appear to be more with proficient at prose than with poetry, though this, of course, is something which may be utterly reversed with tomorrow's mail.

'With so much of her argument Miss Macky is simply drawing red herrings across the trail, and she, in fact, appears to be the one who wishes to sustain a double-standard, one for men, one for women. Surely true freedom demands that they be judged by the highest standards - along with the men.

'She hardly helps put her (or Patmore's) case for the particular gifts of women writers when, in the next breath she claims for Miss Gilbert 'masculine strength and 
breadth of vision.' Emancipate yourself from such images, Miss Macky! They surely can't be of help in making 'a woman's contribution to this shaken world.' Miss Macky is here close to the truth about this supposed 'feminine' view of the world of letters.

'If it was possible to regard everything as a 'contribution' - something done in a spirit of benevolence to a dumb, numb audience - against which the critical voice or thought were illegal, then we would have such a state of art and expression wherein 'mother knows best' and Miss Macky's double-standard would reign supreme. One word would equal another, and 'out-moded' would be consonant with 'classical.' Suffering could be all smoothed away and we would dwell on a static level of happy endings.

'But things being as they are, and there being conflict in life and criticism in art, we don't have to believe Miss Macky's hokum - or mine. It is even possible to choose neither. A few other points from Miss Macky's letter at random:

1: I agree that Miss Rawlinson was a notable omission from the Oxford anthology - she has not been from numbers or The Poetry Yearbook - and from memory I seem to recall that I was one of the two judges who gave her the award mentioned.

2: In Wellington poetry readings the women, including Miss Gilbert, have been featured.

3: Agreed - Allen \& Unwin published Alun Lewis, vintage 1945. One swallow does not make a summer, and the original contention still stands, as does the proviso that I consider the firm in question to be leaders in other publishing fields.

'Finally, I refute the implication of anti-feminism stressed throughout this article. I am prepared to submit my record on this score to Miss Macky at any time. I have willingly given credit to women as writers, as Miss Macky knows, but I stop somewhat short of pride with regard to either her own arguments or Miss Gilbert's last book. I believe the review of that book to be just, and would have expanded the theory behind my view of it had space permitted. For though Miss Macky seems so apologetic for writers of her sex, I would remind her that there are a number of them in this country of whom we are justly proud, whom we welcome to numbers whenever we get the opportunity, and on whose behalf none of us need feel apologetic' (Johnson, 1957 \#7: 28-29). 


\section{Appendix 13}

\section{Publisher: Spiral Collective.}

Heather McPherson is a respected poet and writer in this country. She is well-known as one of the leading lights in the feminist movement and a strong advocate for equal rights for the gay and lesbian community.

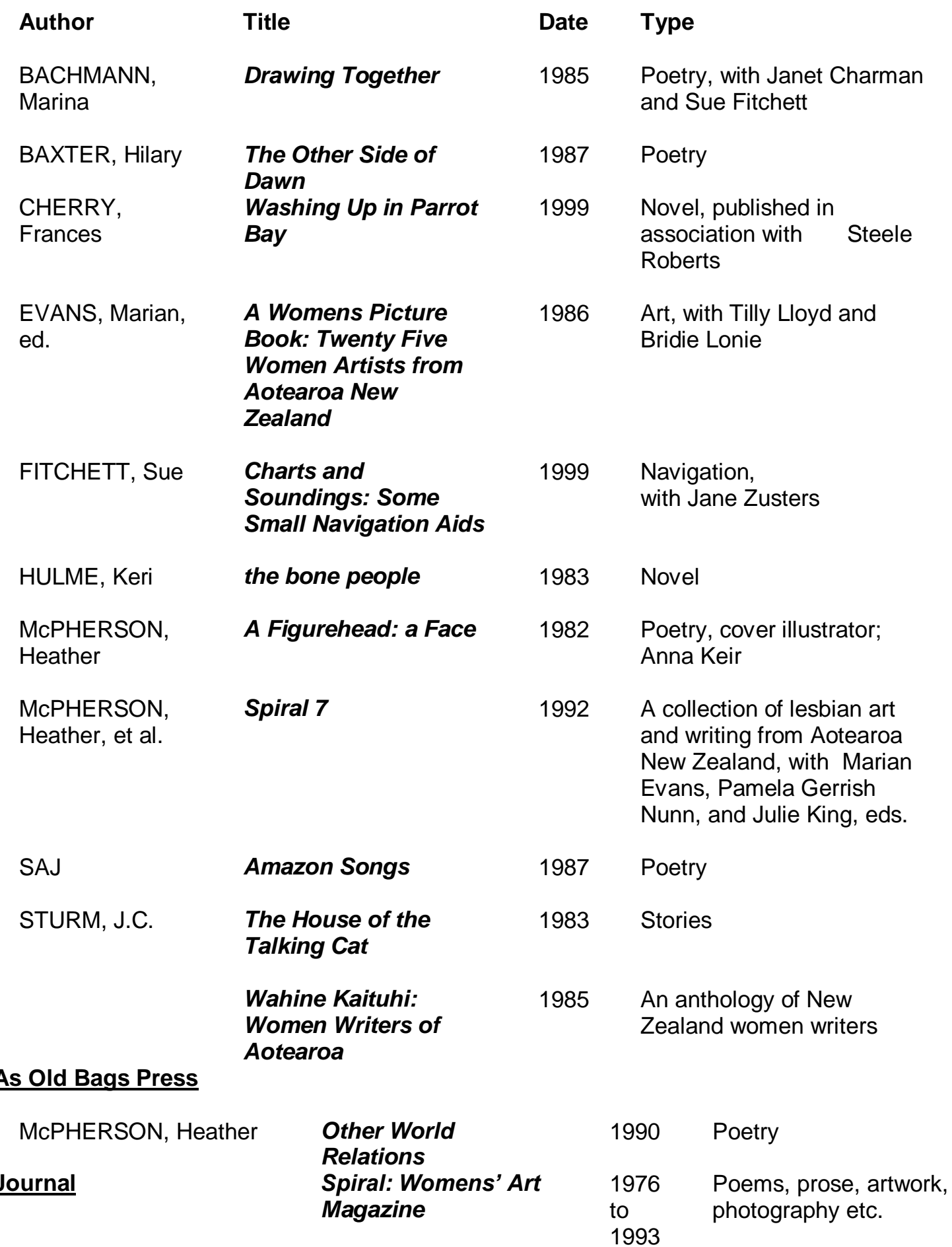




\title{
Heather McPherson's answers to questionnaire on herstory of Spiral Collective
}

\author{
1 - What was your initial reason for getting involved in publishing? Please try to \\ think of this in the spirit of what you were thinking and doing at the time.
}

The context was the early seventies. I'd had poems published in Landfall and approached Leo Bensemann, then Caxton Press and Landfall editor, with a collection. I mentioned that I had become a feminist. He said that Rita Cook - Rita Angus - had become a feminist 'but it didn't do her any good either.' He said that yes, my poems were publishable but to go away and get a grant.

I didn't know how to do this. The book languished unpublished. Some time (and a child) later, in a group called S.H.E. (Sisters for Homophile Equality) I was working on a Homosexual Law Reform submission. It was a large group, my input was negligible. But the experience spurred me into thinking what I would prefer to be doing. With the general excitement of Women's and Gay Liberation in the air, with a number of talented women artists in the group, with their stories of being turned down for publication or by art galleries, I thought I would rather be working with/for women artists.

I made contact with Don Long and Alan Loney who had contacts with American small press associations. Both were helpful and supportive and I printed off flyers on one of their elderly printing presses for a women artists group. The physical work was tiring; I realised that the priority for me was not beautiful and/or old-style printing but getting the work out.

A little before that time Robin Sivewright and Jill Hannah had set up Herstory Press in Wellington and were printing off Womens' Liberation material \& posters \& pamphlets. We negotiated; Katherine Algie, Allie Eagle, Patsy Keene, Zusters, Morrigan, Saj, Paulette Barr and other women, we put together a first issue and Herstory printed it.

\section{2 - Who or what was your main influence behind your decision to publish? These may include literary or non-literary influences.}

Womens Liberation - and the stories of women artists (in the widest sense of painters, writers, photographers, sculptors etc.) of being turned down by publishers and galleries. A spirit of defiance strode abroad ... Some of our ideas were ... Art is not made in a vacuum but out of our lives. Women's and men's lives are different experiences of socialization, child-rearing. Thus women and men artists have and express different values as well as content. Sexism both causes and affects women's marginalisation in the arts by overt and covert censorship of women's experiences as acceptable art content.

In the same way, homophobia censors the expression of lesbian and gay experiences in the arts. Women artists - some great - have been overlooked and dismissed by male gatekeepers of the literary and artistic canon. Publishing and art selection in New Zealand as elsewhere being male-dominated gave little support to women writers and artists and often actively discouraged us. I was familiar with the story of Walt Whitman's self-publication, also of various founders U.S. small magazines such as Margaret Anderson's Little Review. (My primary school experience of making a magazine had some influence also?) The most profound influence on my thinking initially was The First Sex By Elizabeth Gould Davis and a little later, How to Suppress Women's Writing by Joanna Russ.

3 - In your choice of authors was the main consideration for inclusion philosophical, literary or pragmatic?

All three considerations operated. We advertised for women only and printed only what we received. We had a feminist agenda.

But there is a process in defining what is meant by 'feminist' \& what is meant by 'feminist artist' - and our ideas changed over time. For instance, the sixties for women artists had been notorious for the "suicide syndrome" - the brilliant women artists as depressive and/or self-destructive (e.g. Plath, Arbus). As feminists in the early seventies our context 
was that we wanted positive portraits of strong women, we wanted celebrations of being women/lesbian etc., we wanted to erase the images of sex symbol or victim. I once turned down some good work because it was too 'depressing'; if I now question that decision I also note that the writer became very successful in the mainstream. Similar political/philosophical issues arose later with the Women's Gallery e.g ... over women artists showing images of men.

4 - "...and if there is still a number of commissioned works which seem to have been dreamed up by a sabotaging office-boy on an LSD trip, there are now each year a growing quantity of books which worthily add to our literature." Professor J.C. Reid from an article introducing New Zealand Books in Print, written in 1968. I interpret Reid's assessment as an indication of the rift between the acceptable 'worthy' literature as endorsed by academia, and the new wave of sabotaging office boys and girls who at that time commissioned publishers to put out their works, or simply published things themselves, and in many cases the work of their friends. Comment on this quote in relation to the 'Vanity Press' vs 'Real Publishing' debate.

Since the reasons for our Spiral publishing venture were political - sexism, racism and homophobia are political/gatekeeping issues by which a mainstream majority culture suppresses, censors or disregards minority concerns - I have nothing to say on the above issue. Except that long may political publishing flourish, and if political publishing - to extend limits/boundaries, to give a political minority a voice - is considered a Vanity Press concept, long may Vanity Presses prosper and flourish.

5 - Initially, was your focus outwardly cosmopolitan or inwardly New Zealand looking, and how has this emphasis changed over the years?

Initially, much feminist and Women Artists Movement theory came from overseas, particularly the United Kingdom and the United States. With growing confidence, we women/artists applied \& modified it to New Zealand conditions in our own consciousnessraising groups. Our main focus was to publish New Zealand women, to build connections and rapprochements between artists working in different media and to get New Zealand women's' art and voices heard overseas; there was in the seventies quite a vital exchange of arts magazines with Australia, the UK and the US feminist presses. I have not been involved in Spiral publishing since Spiral 7 and am not aware of changes in policy.

6 - What were your methods of printing and distribution as a publisher? Did you receive any financial or other assistance from either public organisations, or private sponsorship?

Printing of first issues was done by the feminist Herstory Press. Later local printing presses were used - the magazine was typeset, laid-out and mocked up to printing quality. Distribution was always a problem. The women's' community in Christchurch (where the first 4 issues originated) helped; the Women's bookstores and Broadsheet (in Auckland), were helpful; individual members of each collective did much wonderful work to get Spiral throughout the country. The first four Spiral issues were, apart from sales, subscriptions and donations, mostly funded by the Christchurch women's/lesbian community dances. When a sales cash box disappeared at a conference, the Spiral collective held a special dance to replace the stolen money. Briefly, the distributing was voluntary, both it and fundraising communal.

7 - How much of your publishing was commissioned and paid for (either fully or partially) by the author? Was your operation helped by the voluntary work of friends and family?

Spiral could not have existed without the wonderful voluntary support of friends, partner(s) and the Christchurch lesbian community. The first issue's loose pages were laid out in Saj's living room of The Blue House and literally stapled together by about a dozen women - the house's occupants and the Spiral collective. I guess the authors paid their 
time, paper, postage. For the first issue(s?) we gave the authors a magazine and a token payment (\$2)(!) to acknowledge their 'work'; this was to be augmented but we never made enough money to fully cover expenses. I don't remember when we stopped the token payment; nor what happened after I left the collective -

(after issue 4, returning to share the editorial role for issue 7).

8 - What has been the cost to you personally in terms of time, money and resources, of being involved in publishing in New Zealand? You may consider this in relation to more difficult areas such as relationships with friends, family etc. also.

The cost ... mmmm, I have tended to think rather of rewards - to have been in an exciting venture in an exciting time, to have met many talented artists, to have made life-long friendships and argued and worked with some wonderful women, good at their jobs writers, artists, printers, layout artists or whatever ... also to see the inspiration continue, so that later women's' collectives published under the name/imprint (e.g. the bone people) ... I guess one cost was extra stress - a solo mother raising a son and doing a part-time paid job to augment my benefit, I never had any spare cash let alone being able to subsidize a magazine. The other cost was having little time for my own writing - I relinquished my involvement with the collective to write more.

9 - Where do you place yourself and your achievements as a publisher (and as a writer if applicable) in the history of the modern-day New Zealand literary scene? Do you feel that your contribution has been adequately acknowledged.

I place myself in an accident of herstory - being the person in the place at the time when a conjunction of interests - personal and political - offered the opportunity, with other women, to make a statement about women's work ... Re the second question - do I feel my contribution has been adequately acknowledged - l'd have to ask by whom? By the New Zealand literary scene? It could be surprising to be acknowledged at all, given some of the hostile editorializing at the time ... and l'd rather be acknowledged for my writing. But by women artists and friends? Yes. By feminist herstorians? Yes.

H.McP. Hamilton, 2000. 